MURILO PAES LIMA

\begin{abstract}
ANÁLISE CRÍTICA DO PROCESSO DE PLANEJAMENTO DA IMPLANTAÇÃO DE UM ESCRITÓRIO DE GERENCIAMENTO DE PROJETOS
\end{abstract}

São Paulo 


\section{ANÁLISE CRÍTICA DO PROCESSO DE PLANEJAMENTO DA IMPLANTAÇÃO DE UM ESCRITÓRIO DE GERENCIAMENTO DE PROJETOS}

Dissertação apresentada à Escola Politécnica da Universidade de São Paulo para obtenção do Título de Mestre em Engenharia

Área de Concentração:

Engenharia Naval e Oceânica

Orientador:

Prof. Dr. Marcelo Ramos Martins

São Paulo 
Este exemplar foi revisado e alterado em relação à versão original, sob responsabilidade única do autor e com a anuência de seu orientador.

São Paulo, de maio de 2008.

Assinatura do autor

Assinatura do orientador

FICHA CATALOGRÁFICA

Lima, Murilo Paes

Análise crítica do processo de planejamento da implantação de um escritório de gerenciamento de projetos / M. P. Lima ed.rev. - São Paulo, 2008.

$179 \mathrm{p}$.

Dissertação (Mestrado) - Escola Politécnica da Universidade de São Paulo. Departamento de Engenharia Naval e Oceânica.

1. Administração de projetos 2. Planejamento estratégico 3. Administração de empresas I. Universidade de São Paulo. Escola Politécnica. Departamento de Engenharia Naval e Oceânica II. t. 


\section{FOLHA DE APROVAÇÃO}

Murilo Paes Lima

Análise crítica do processo de planejamento da implantação de um escritório de gerenciamento de projetos.

Dissertação apresentada à Escola

Politécnica da Universidade de São Paulo para obtenção do Título de Mestre em Engenharia.

Área de Concentração: Engenharia Naval e Oceânica.

Aprovado em: / 2008.

Banca Examinadora

Prof. Dr.

Instituição: Assinatura:

Prof. Dr.

Instituição: Assinatura:

Prof. Dr. Instituição: Assinatura: 


\section{DEDICATÓRIA}

Para minha esposa Vanessa, meu maior amor.

E para meus pais, que sempre me apoiaram em tudo. 


\section{AGRADECIMENTOS}

Ao meu caro orientador, professor Marcelo Ramos Martins, pela orientação, apoio, dedicação e os fundamentais conselhos, que muito ajudaram no desenvolvimento deste trabalho.

A todos da empresa onde trabalho, pelas mais variadas e profundas discussões e trocas de informações que tivemos nestes 4 anos de convivência. Em especial agradeço aos meus chefes por me permitirem participar deste grande projeto de implantação de seu EGP e pela paciência em dividir meu tempo com a realização deste mestrado. Agradeço também ao José Eduardo pelo constante incentivo profissional e acadêmico.

Ao amigo Edison Braun, pela constante troca de idéias e pelos oportunos comentários e sugestões.

Aos meus pais, Newton e Consuelo, exemplos a serem seguidos, agradeço por toda base que me foi dada, sem a qual nada seria possível. E por todo o carinho e apoio que sempre me foi dado.

A toda minha família, tanto do meu lado quanto do lado de minha esposa, pelo carinho, apoio e incentivo.

Especial agradecimento a minha amada esposa Vanessa, por todo seu carinho, amor, dedicação e incentivo, que foram fundamentais para que eu pudesse concluir este trabalho.

$\mathrm{E}$ a todos demais amigos que contribuíram nesta longa jornada, meus sinceros agradecimentos. 


\section{RESUMO}

A implantação de estruturas como o Escritório de Gerenciamento de Projetos (EGP) é uma ação que tem sido muito utilizada recentemente visando desenvolver e aprimorar a gestão de projetos nas organizações. Num momento em que cada vez mais as empresas estão utilizando projetos para implantar o seu planejamento estratégico, torna-se fundamental garantir a maior eficiência e eficácia possível na gestão de seus projetos.

A utilização de um EGP pode trazer uma série de benefícios à gestão de projetos de uma organização; entretanto, sua implantação é um processo complexo que deve ser planejado com cuidado.

O objetivo desta dissertação é identificar os fatores que influenciam o processo de planejamento da implantação de um EGP e analisá-los quanto à forma que sua influência é exercida, de tal modo que propicie uma implantação de sucesso.

Este objetivo é alcançado através da análise do processo de constituição de um EGP, do processo de planejamento estratégico do EGP e do processo de planejamento de suas fases.

Dentro do processo de planejamento estratégico do EGP, são detalhadas as análises que envolvem o diagnóstico da situação atual da empresa, os benefícios esperados, as condições de viabilidade para implantação, a definição dos objetivos estratégicos, os tipos de EGP, suas funções e a influência da estrutura organizacional. São ainda analisadas a influência da cultura organizacional, da maturidade em gestão de projetos, dos fatores críticos de sucesso e os recursos e custos envolvidos na implantação.

A dissertação ainda contempla um estudo de caso da implantação de um EGP em uma grande empresa brasileira, líder em seu setor. Neste estudo de caso buscou-se confrontar as conclusões das análises realizadas com as condições e resultados verificados no caso específico. 
Como conclusão do estudo, fica claro que não existe uma "receita de bolo" para a implantação de um EGP. Os responsáveis pela implantação devem entender quais fatores afetam o planejamento de um EGP e trabalhar no intuito de melhor adaptar estes fatores à implantação do EGP de sua organização.

Deste modo, esta dissertação atinge seu objetivo e oferece ao leitor uma visão de quais são estes fatores, como eles afetam o planejamento e quais os possíveis caminhos que podem ser tomados para se implantar com sucesso um EGP.

Palavras Chave: Escritório de Gerenciamento de Projetos (EGP), Gerenciamento de Projetos, Planejamento. 


\begin{abstract}
The implantation of structures such as the Project Management Office (PMO) is an action that has been used much recently seeking the development and improves the project management in the organizations. At a moment in that each time more and more companies are using projects to establish their strategic planning, it becomes fundamental to assure the greater efficiency and efficacy possible in the management of their projects.
\end{abstract}

The use of a PMO may bring many benefits to the project management of an organization; however, its implantation is a complex process that needs to be planed with care.

The objective of this dissertation is to identify the factors that influence the process of planning the implantation of a PMO and to analyze them as the form that its influence is exercised, in such a way that propitiates a successful implantation.

This objective is obtained through analyzes of the process of constitution of a PMO, the process of strategic planning of the PMO and the planning process of its phases.

Within the process of strategic planning of the PMO, are detailed analyzes that involve the diagnosis of the present situation of the company, the benefits expected, the conditions of viability of implantation, the definition of strategic objectives, the types of $\mathrm{PMO}$, its functions and the influence of the organizational structure. The influence of organizational culture, the maturity of project management, the critical factors of success and the resources and costs involved in the implantation are still being analyzed.

This dissertation still contemplates a case study of implantation of a PMO in a large Brazilian company, leader in its sector. This case study aims to compare the conclusions of analyzes done with the conditions and results verified in the specific case. 
As conclusion of this study, it has become evident that there is no simple solution for implanting a PMO. The people responsible for the implantation must understand which factors affect the planning of the PMO and work to better adapt this factors for implantation of their organization.

In this way, this dissertation reach's its objective and offers to reader a vision of these factors, how they affect the planning and which are the possible ways that could be taken to implant with success a PMO.

KeyWords: Project Management Office (PMO), Project Management, Planning 


\section{LISTA DE FIGURAS}

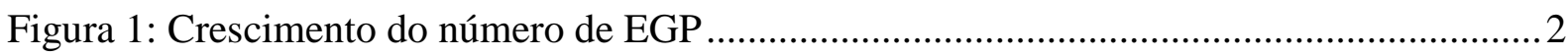

Figura 2: Distribuição da Idade dos EGP (dados de 2005) ...................................................... 3

Figura 3: Etapas de Implantação de um EGP - Foco de Estudo da Dissertação........................ 8

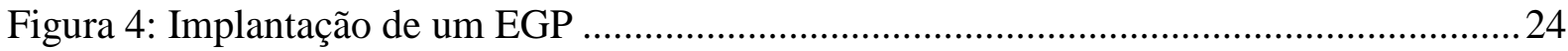

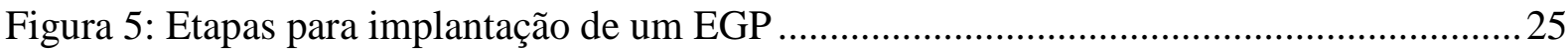

Figura 6: Relação entre foco de atuação e valor para a empresa...........................................29

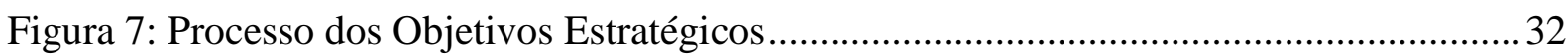

Figura 8: Exemplo de aplicação dos Modelos de EGP de Casey e Peck. ................................ 46

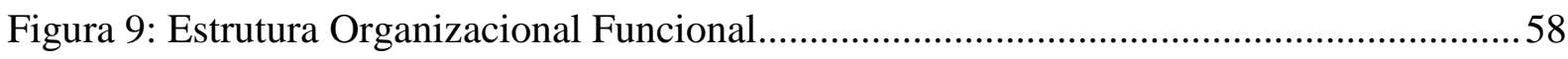

Figura 10: Estrutura Organizacional Projetizada................................................................. 59

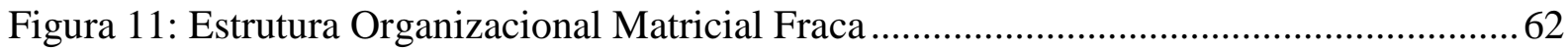

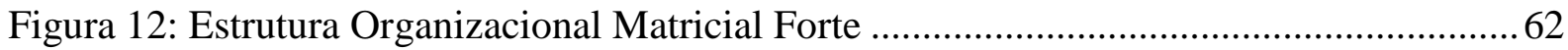

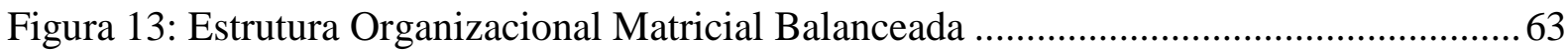

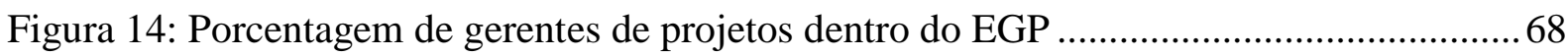

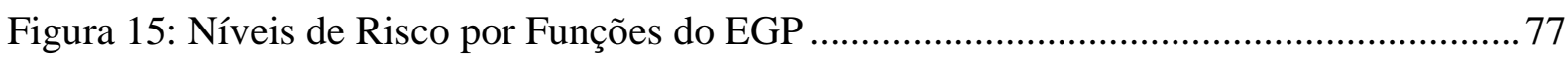

Figura 16: Maturidade e Excelência nas empresas com gestão de projetos ............................. 79

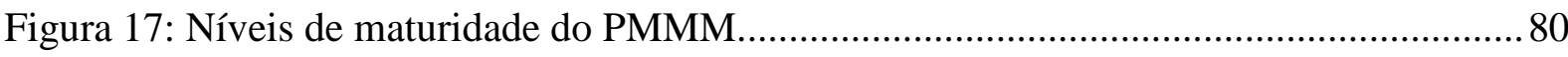

Figura 18: Fases do Ciclo de Vida para Maturidade em Gestão de Projetos ............................ 83

Figura 19: Funções do EGP x Nível de Maturidade................................................................90

Figura 20: Pessoas alocadas no EGP excluindo os gerentes de projetos .................................96

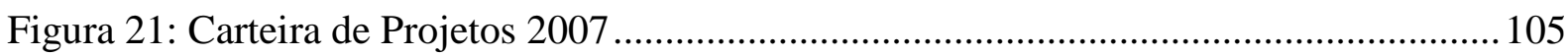

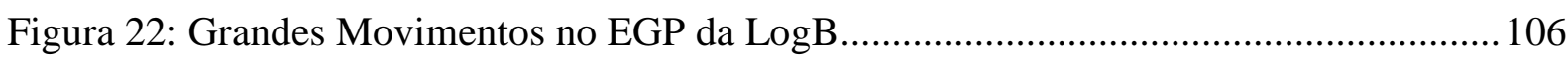

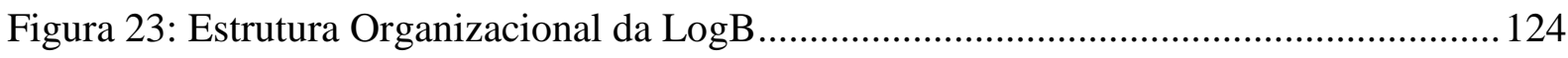

Figura 24: Divisão da Estrutura Organizacional da UN em Regionais ................................. 124

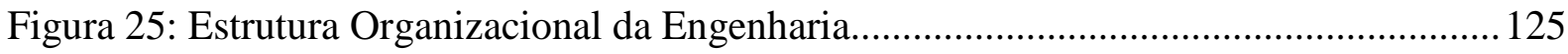

Figura 26: Coordenação dos Projetos via Estrutura Funcional ............................................ 126

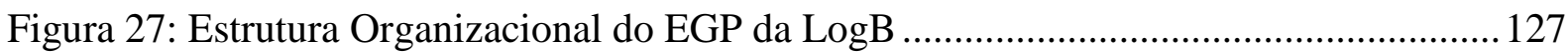

Figura 28: Alteração da Estrutura Organizacional para o Tipo Matricial Forte..................... 130

Figura 29: Gráfico de Pontuação do Ciclo de Vida do PMMM na LogB ............................. 145

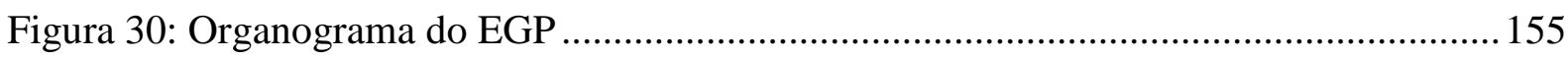

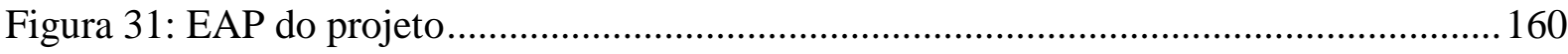




\section{LISTA DE TABELAS}

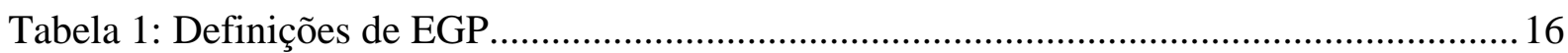

Tabela 2: Nomes de Entidades Organizacionais ................................................................. 19

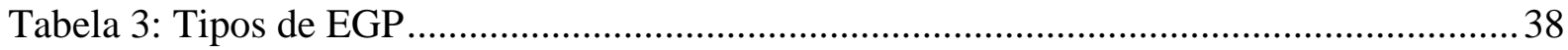

Tabela 4: Tipos de EGP por suas Responsabilidades........................................................... 41

Tabela 5: Funções de Gerenciamento de Projetos por tipos de EGP ...................................... 44

Tabela 6: Funções de EGP em ordem decrescente de importância (continua) ........................ 48

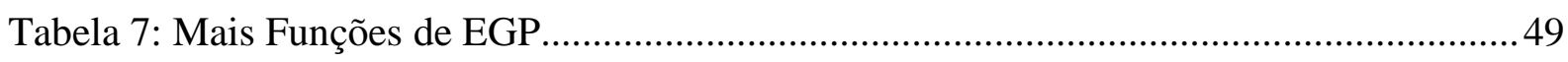

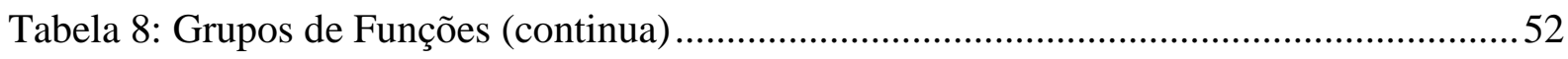

Tabela 9: Características das Estruturas Organizacionais ..................................................57

Tabela 10: Grupos de Funções x Responsabilidade sobre os resultados dos projetos ............. 71

Tabela 11: Fatores Críticos de Sucesso (continua)................................................................. 91

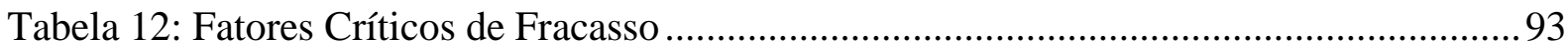

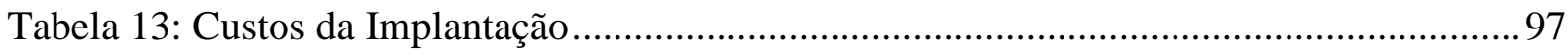

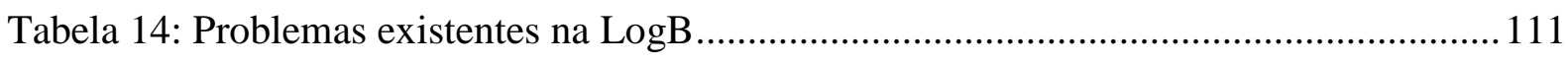

Tabela 15: Funções atribuídas ao EGP da LogB (continua) ............................................... 120

Tabela 16: Grupos de Funções x Responsabilidade atribuída ao EGP da LogB ................... 132

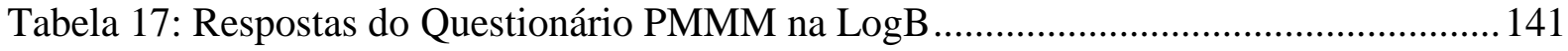

Tabela 18: Pontuação do Ciclo de Vida do PMMM na LogB................................................ 142 


\section{LISTA DE ABREVIATURAS E SIGLAS}

$\begin{array}{lll}\text { EAP } & - & \text { Estrutura Analítica do Projeto } \\ \text { EGP } & - & \text { Escritório de Gerenciamento de Projetos } \\ \text { PMBoK } & - & \text { Project Management Book of Knowledge } \\ \text { PMI } & - & \text { Project Management Institute } \\ \text { PMMM } & - & \text { Project Management Maturity Model } \\ \text { PMO } & - & \text { Project Management Office } \\ \text { PMP } & - & \text { Project Management Professional } \\ \text { UN } & - & \text { Unidade de Negócio }\end{array}$




\section{SUMÁRIO}

INTRODUÇÃO 


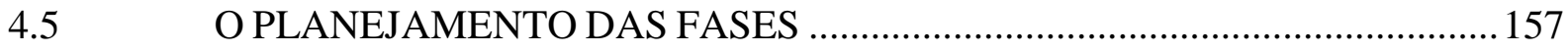

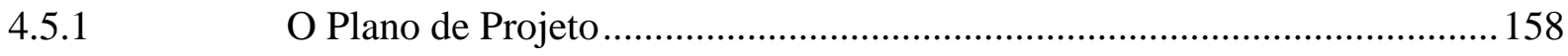

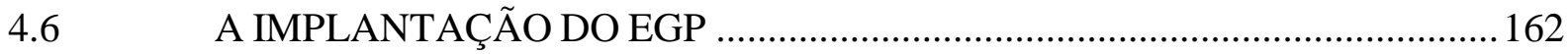

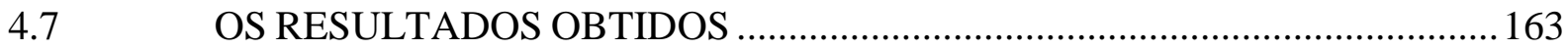

4.8 CONCLUSÕES E RECOMENDAÇÕES DO ESTUDO DE CASO................... 166

$5 \quad$ CONCLUSÕES E RECOMENDAÇÕES .........................................168

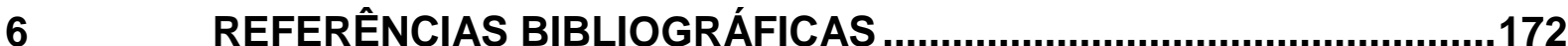

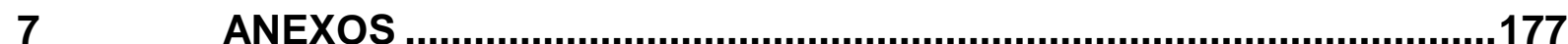

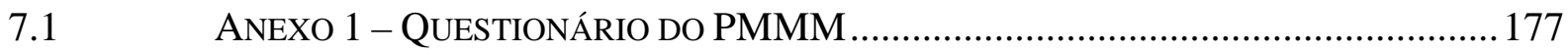




\section{INTRODUÇÃO}

\subsection{CONTEXTUALIZAÇÃO DO TRABALHO}

As empresas elaboram seu planejamento estratégico no intuito de manter ou criar um novo posicionamento de mercado, estabelecendo metas e desafios que uma vez atingidos permitirão alcançar os seus objetivos estratégicos. Uma das formas utilizadas pelas empresas para executar o seu planejamento estratégico é transformando seus objetivos, metas e estratégias em projetos (OLIVEIRA, 2002). Esses projetos, uma vez executados conforme o planejado, fornecem as bases para que as empresas cumpram seu planejamento estratégico.

Perante a grande importância que os projetos possuem na execução do planejamento estratégico da empresa, torna-se fundamental para qualquer empresa que seus projetos sejam bem gerenciados.

Com o objetivo de garantir que os projetos sejam gerenciados adequadamente, muitas empresas têm recorrido à implantação de Escritórios de Gerenciamento de Projetos (EGP), termo proveniente do inglês Project Management Office (PMO). Os EGP são estruturas formadas na organização com o intuito de promover e melhorar a gestão de projetos, trabalhando para resolver os problemas existentes e buscando alcançar níveis satisfatórios de eficiência e eficácia na gestão de projetos. Com isto se tenta garantir a concretização do planejamento estratégico da empresa.

Nos últimos anos os EGP se tornaram muito populares nas empresas (HOBBS; AUBRY, 2007), mas os primeiros EGP surgiram no final da década de 50 , sendo utilizados em grandes projetos militares, na construção civil pesada e na indústria aeroespacial (KERZNER, 2002). Eles tinham a função de atender a um único projeto, fornecendo serviços de atualização de cronogramas e preparação da documentação do cliente, além de ser a equipe de comando da empreiteira e ponto focal de toda comunicação com os clientes (KERZNER, 2002).

Os EGP começaram então a sofrer um processo de evolução e, no início da década de 70, com o advento dos mainframes, o papel do EGP mudou para se tornar um 
departamento de especialistas nas ferramentas e softwares de projetos, prestando serviços para outros departamentos da empresa. Ele deixou de atender a um único cliente para ser um centro de informações da empresa referente a assunto de projetos (KERZNER, 2002).

No início da década de 90, o EGP começou a ser expandido para outras indústrias e ganhou novas atribuições, como padronização de metodologias, treinamentos e planejamento estratégico para o aperfeiçoamento da gestão de projetos (KERZNER, 2002).

O aumento extressivo do número de EGP ocorreu a partir de meados da década de 90 e vem crescendo desde então, conforme representado na Figura 1, obtida de Dai e Wells (2004).

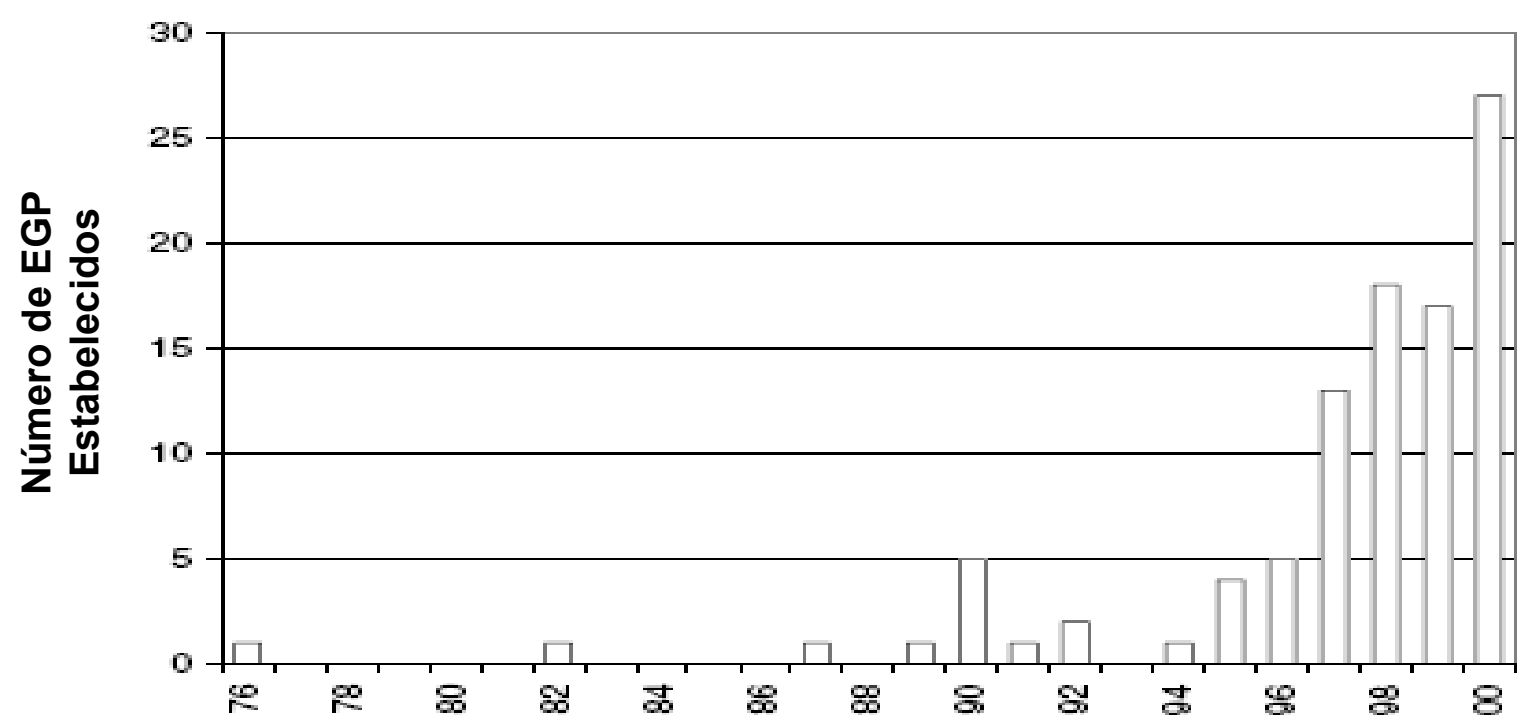

Figura 1: Crescimento do número de $\mathrm{EGP}^{1}$

(Fonte: Dai e Wells, 2004)

Porém, uma questão que surge é se este grande número de EGP criados está realmente cumprindo as tarefas que Ihes foram designadas, agregando valor $e$ sendo bem aceitos dentro da organização.

\footnotetext{
${ }^{1} \mathrm{O}$ número de EGP estabelecidos indicado na figura está relacionado com o total de respondentes obtidos na pesquisa dos autores Dai e Wells (2004).
} 
Uma recente pesquisa realizada por Hobbs e Aubry (2007), da Universidade de Quebec em Montreal, Canadá, com 500 empresas do mundo inteiro, mostra que o cenário real é de que muitos EGP estão ainda lutando para provar o seu valor e que muitos deles estão falhando, sendo fechados ou totalmente reformulados. Segundo esta pesquisa, 54\% dos EGP (EGP conforme estão estruturados hoje) foram criados nos últimos dois anos, como é observado na Figura 2 (dados recolhidos em 2005).

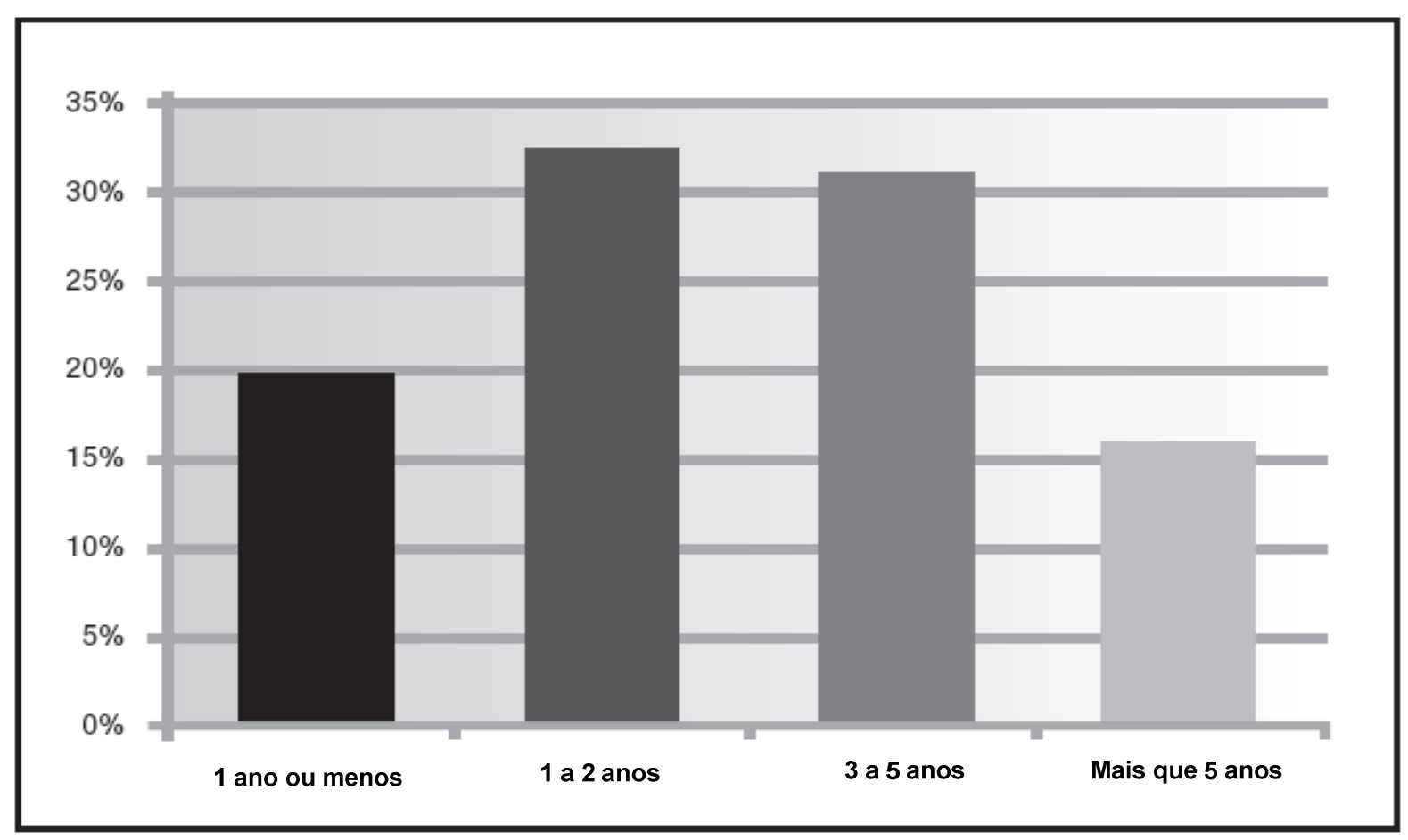

Figura 2: Distribuição da Idade dos EGP (dados de 2005)

(Fonte: Hobbs e Aubry, 2007)

Os autores Hobbs e Aubry (2007) concluíram desta pesquisa que novos EGP têm sido criados numa taxa relativamente alta e também que EGP têm sido fechados ou radicalmente reestruturados quase tão rápido quanto têm sido criados.

Nesta mesma pesquisa, Hobbs e Aubry (2007) fizeram a seguinte pergunta: "A relevância ou mesmo a existência do EGP tem sido seriamente questionada nos últimos anos?". 42\% dos respondentes disseram que "sim", ou seja, que a existência ou relevância foi questionada. Porém, os autores da pesquisa acreditam que esse percentual pode ser maior, devido à pesquisa ter sido realizada apenas com os EGP em funcionamento atualmente e por haver uma tendência de que apenas as pessoas favoráveis ao tema tenham tido a preocupação em responder a pesquisa. 
Portanto, essa pesquisa revela que mais de $42 \%$ dos EGP existentes sofrem pressão para provar seu valor. Estudar os motivos porque isso ocorre torna-se importante para o futuro da existência dos Escritórios de Gerenciamento de Projetos nas organizações.

\subsection{OBJETIVO DO TRABALHO}

De acordo com a pesquisa de Hobbs e Aubry (2007) comentada no item anterior, um número expressivo de EGP tem sido fechado ou reestruturado nos últimos anos. $\mathrm{O}$ pressuposto adotado é que um planejamento da criação do EGP bem realizado poderia evitar estes problemas e garantir que o EGP pudesse facilmente mostrar 0 seu valor à organização.

Em alinhamento com este pressuposto, este trabalho objetiva analisar os fatores que afetam o processo de planejamento da criação de um Escritório de Gerenciamento de Projetos. Busca, portanto, fornecer elementos para uma realização consistente do planejamento da criação de um EGP.

A pergunta a ser respondida nesta dissertação é:

Quais são os fatores e como eles influenciam o processo de planejamento da implantação de um Escritório de Gerenciamento de Projetos de tal forma que propicie uma implantação de sucesso?

\subsection{REVISÃO BIBLIOGRÁFICA}

Esta dissertação parte do pressuposto de que um planejamento da criação de um Escritório de Gerenciamento de Projetos bem feito pode diminuir suas chances de fracasso, contribuindo para reverter as altas taxas de fracasso apresentadas por Hobbs e Aubry (2007) em sua pesquisa realizada com mais de 500 empresas de todo o mundo. 
Para definir a metodologia de pesquisa científica aplicável a esta dissertação, foram utilizadas as referências Gil (2007), Lakatos e Marconi (2003) e Trujillo (1982).

No capítulo 3, para elaboração dos fundamentos teóricos, foram analisados diversos assuntos, oriundos de diversas fontes, conforme apresentado sucintamente nos próximos parágrafos, destacando apenas as principais fontes.

Os conceitos de EGP são discutidos por: Englund, Graham e Dinsmore (2003), Casey e Peck (2001), Verzuh (2005), Desouza e Evaristo (2006), Andersen, Henriksen e Aarseth (2006), Hobbs e Aubry (2007) e Crawford (2002).

O processo de constituição de um EGP é discutido por: Andersen, Henriksen e Aarseth (2006), Crawford (2002), Englund, Graham e Dinsmore (2003) e Block e Frame (1998).

A definição dos objetivos estratégicos de um EGP é discutida por: Costa (2006), Oliveira (2002) e Crawford (2002).

Os tipos de EGP e como são eles constituídos são discutidos por: Hobbs e Aubry (2007), Verzuh (2005), Dinsmore (1998) e Casey e Peck (2001).

Tanto as funções que um EGP pode assumir como seus agrupamentos são discutidos por: Hobbs e Aubry (2007), Verzuh (2005), Kerzner (2003), Rad e Raghavan (2000) e Block e Frame (1998).

A influência da estrutura organizacional da empresa na constituição de um EGP é discutida por: PMI (2004), Patah (2004), Kerzner (2001a), Verzuh (2005) e Block e Frame (1998).

A influência da cultura organizacional da empresa na constituição de um EGP é discutida por: Dinsmore (2001 e 2002), Crawford (2002), Block e Frame (1998), Fleury e Sampaio (2002), Kerzner (2003) e Fischer (2002). 
A influência da maturidade em gestão de projetos da empresa na constituição de um EGP é discutida por Kerzner (2001b, 2002).

E a influência dos fatores críticos de sucesso para implantação de um EGP é discutida por: Crawford (2002), Verzuh (2005), Andersen, Henriksen e Aarseth (2007), Patah (2004), Hobbs e Aubry (2007), Rad e Raghavan (2000) e Kerzner (2003).

\subsection{A ESTRUTURA DA DISSERTAÇÃO}

Esta dissertação é estruturada em cinco capítulos.

O capítulo 1 contém a introdução do trabalho e a descrição do seu objetivo.

O capítulo 2 apresenta a metodologia de pesquisa científica utilizada para se atingir os objetivos da dissertação.

No capítulo 3 são apresentados os fundamentos teóricos nos quais se baseiam a dissertação e é realizada a análise crítica para identificação dos fatores que afetam o processo de planejamento da implantação de um EGP.

No capítulo 4 é apresentado um estudo de caso onde se busca confrontar as conclusões das análises realizadas no capítulo 3 com as condições e resultados verificados no caso específico.

No capítulo 5 são apresentadas as conclusões e recomendações da dissertação. 


\section{METODOLOGIA DE PESQUISA}

Neste capítulo é apresentada a metodologia de pesquisa utilizada para atingir o objetivo proposto da dissertação.

Para Salvador (1980) apud Lakatos e Marconi (2003), a dissertação é "um estudo teórico, de natureza reflexiva, que consiste na ordenação de idéias sobre determinado tema". Pode ser do tipo Expositiva, "quando reúne e relaciona material obtido de diferentes fontes, expondo o assunto com fidedignidade e demonstrando habilidade não só de levantamento, mas também de organização"; ou ser do tipo Argumentativa, "quando requer interpretação das idéias apresentadas e posicionamento do pesquisador".

Esta dissertação reúne características dos dois tipos apresentados por Lakatos e Marconi (2003), pois reúne material obtido de diversas fontes, expondo o assunto de maneira organizada (tipo expositiva) e também requerendo o posicionamento do pesquisador, devido à necessidade de realização de análise crítica sobre o assunto estudado (tipo argumentativa).

Para o desenvolvimento da dissertação, é necessária a definição do problema a ser estudado. Para Gil (2007), um problema científico é uma "questão não solvida e que é objeto de discussão, em qualquer domínio do conhecimento". Para Rudio (1979) apud Lakatos e Marconi (2003), "formular o problema consiste em dizer, de maneira explícita, clara, compreensível e operacional, qual a dificuldade com a qual nos defrontamos e que pretendemos resolver, limitando o seu campo e apresentando suas características. Desta forma, o objetivo da formulação do problema da pesquisa é torná-lo individualizado, específico, inconfundível".

Segundo Gil (2007), um pesquisador também pode se interessar em estudar áreas já exploradas, com o objetivo de determinar com maior especificidade e precisão as condições em que certos fenômenos ocorrem, como podem ser influenciados por outros fenômenos ou verificar variações sobre eles. 
Para Gil (2007), um problema científico deve ser formulado como pergunta, ser claro e preciso, ser empírico, ser suscetível de solução e ser delimitado a uma dimensão viável.

Dessa forma, o problema de pesquisa desta dissertação está compatível com as definições apresentadas, sendo caracterizado em forma de pergunta. A pergunta a ser respondida nesta dissertação é:

Quais são os fatores e como eles influenciam o processo de planejamento da implantação de um Escritório de Gerenciamento de Projetos de tal forma que propicie uma implantação de sucesso?

Reforçando o delineamento do problema estudado nesta dissertação, a Figura 3 caracteriza as etapas genéricas de constituição e implantação de um EGP. Inicialmente, decide-se por implantar um EGP. Após esta decisão é necessário planejar a sua implantação, para posteriormente implantá-lo e operá-lo. A Figura 3 deixa claro que o foco de estudo desta dissertação é analisar criticamente os fatores que afetam a etapa de "planejar a implantação do EGP".

Portanto, não é objetivo desta dissertação tratar de assuntos relacionados ao "como" e ao "por que" são tomadas as decisões por se implantar um EGP. Leva-se em consideração que a decisão por implantar o EGP foi tomada e que necessita-se planejar a sua implantação.

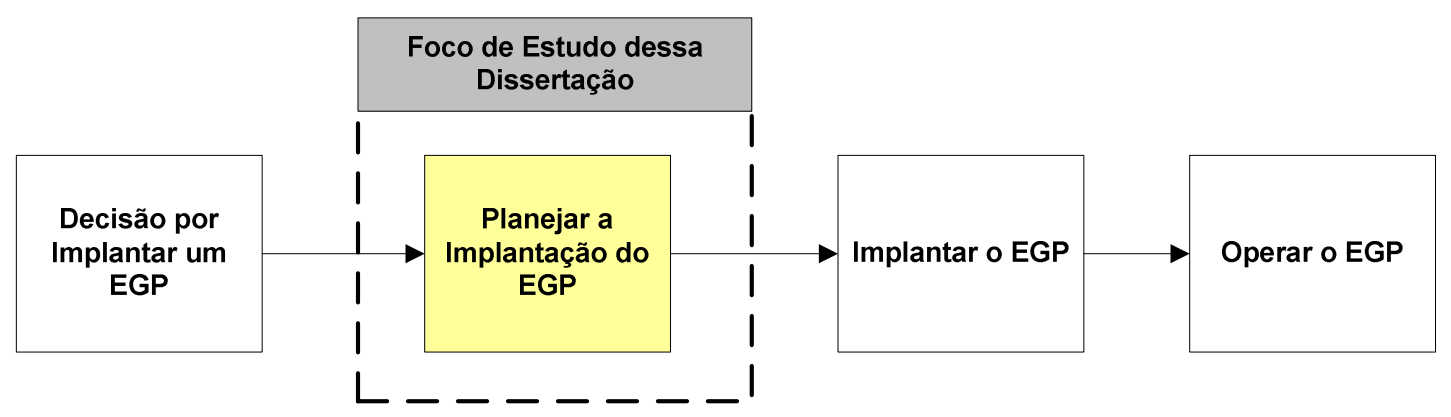

Figura 3: Etapas de Implantação de um EGP - Foco de Estudo da Dissertação (Fonte: Autor)

Para atender ao objetivo proposto, a dissertação foi dividida em duas partes: uma primeira parte, que pode ser considerada independente da segunda, onde é 
realizada uma pesquisa exploratória, que busca através de uma pesquisa bibliográfica, realizar uma análise crítica sobre os fatores que afetam o planejamento da implantação de um Escritório de Gerenciamento de Projetos; e uma segunda parte, onde é realizada uma pesquisa de campo para avaliar as conclusões obtidas na primeira parte.

Sendo a primeira parte independente da segunda, tem-se que os objetivos da pesquisa são alcançados considerando apenas a primeira parte. Dessa forma, a identificação e a análise crítica dos fatores que afetam o planejamento da implantação de um EGP são discutidas e atendidas pela pesquisa bibliográfica da primeira parte desta dissertação. Como uma forma de acrescentar valor à dissertação, é apresentada na segunda parte da dissertação, uma pesquisa de campo com o intuito de avaliar e validar as conclusões obtidas na primeira parte.

O caráter exploratório da pesquisa foi utilizado nas duas partes da dissertação. Este foi utilizado, pois, segundo Gil (2007), visa proporcionar maior familiaridade com o problema, com vistas a torná-lo mais explícito ou a construir hipóteses. Estas pesquisas têm como objetivo principal o aprimoramento de idéias ou a descoberta de intuições. Para Tripodi (1975) apud Lakatos e Marconi (2003), as pesquisas exploratórias têm o objetivo de formular questões ou problemas, com a tripla finalidade: desenvolver hipóteses, aumentar a familiaridade do pesquisador com um ambiente, fato ou fenômeno, para a realização de uma pesquisa futura mais precisa ou modificar e clarificar conceitos. Segundo Gil (2007), embora o planejamento da pesquisa exploratória seja bastante flexível, na maioria dos casos, ela assume a forma de pesquisa bibliográfica ou de estudo de caso.

Dessa forma, na primeira parte desta dissertação é utilizada uma pesquisa bibliográfica. Esta foi adotada porque, segundo Gil (2007), as pesquisas que se propõem à análise das diversas posições acerca de um problema costumam ser desenvolvidas mediante pesquisas bibliográficas. Segundo este autor, embora em quase todos os estudos seja exigido algum tipo de trabalho dessa natureza, há pesquisas desenvolvidas exclusivamente a partir de fontes bibliográficas. Para Trujillo (1982), a pesquisa bibliográfica tem a finalidade de conhecer as contribuições científicas que se efetuaram sobre determinado assunto. Segundo Lakatos e 
Marconi (2003), a pesquisa bibliográfica não é uma mera repetição do que já foi dito ou escrito sobre determinado assunto, mas sim é uma forma de propiciar o exame de um tema sob um novo enfoque ou abordagem, chegando a conclusões inovadoras.

A pesquisa bibliográfica será utilizada para identificar e analisar criticamente os fatores que devem ser considerados na fase de planejamento da criação de um EGP. Para se chegar a este objetivo, serão estudados e analisados criticamente os seguintes assuntos relacionados ao EGP:

Conceito, benefícios e fatores motivadores;

> O planejamento estratégico do EGP;

$>$ Tipos e características do EGP;

> Funções, autoridade e estruturas do EGP;

> Influência da cultura organizacional e da maturidade em gestão de projetos;

> Recursos e custos necessários para sua implantação;

> Fatores críticos de sucesso e fracasso;

Para a segunda parte desta dissertação, foi utilizado como método de pesquisa o estudo de caso. Para Yin (2005), o estudo de caso representa a estratégia preferencial de estudo quando se satisfaz três condições: as questões da pesquisa devem ser do tipo "como" e "por que"; o pesquisador não deve ter controle sobre os eventos investigados; e o foco da pesquisa deve ser um fenômeno contemporâneo inserido em algum contexto da vida real.

Para Yin (2005), a utilização do estudo de caso como método de pesquisa apresenta como vantagens a manutenção das características principais de eventos da vida real e a garantia da visão holística do problema estudado. Segundo Gil (2007) e Yin (2005), o estudo de caso é utilizado com um dos seguintes propósitos:

Explorar situações da vida real cujos limites ou resultados não estão claramente definidos;

> Preservar o caráter unitário do objeto estudado;

> Descrever a situação do contexto em que está sendo feita determinada investigação; 
> Descrever o contexto da vida real no qual a intervenção ocorreu;

> Formular hipóteses ou desenvolver teorias;

> Explicar as variáveis causais de determinado fenômeno em situações muito complexas que não possibilitam a utilização de levantamentos e experimentos;

> Fazer uma avaliação da intervenção realizada, ainda que de forma descritiva.

Portanto, as condições para utilização do estudo de caso como método de pesquisa são satisfeitas na proposta de estudo dessa dissertação, tendo em vista que o objeto deste estudo é o entendimento e análise crítica de "como" o planejamento pode ser realizado com sucesso, para aplicação em um fenômeno recente (o EGP) no qual o pesquisador não tem controle, e trata-se também de um fenômeno contemporâneo. O propósito de utilização do estudo de caso desta dissertação é, conforme as sugeridas por Gil (2007) e Yin (2005), explorar a situação da vida real do EGP analisado, cujo limite e resultados não estão claramente definidos.

Segundo Stake (2000) apud Gil (2007), existem três modalidades de estudos de caso: intrínseco, instrumental e coletivo. O estudo de caso intrínseco é aquele em que o caso constitui o próprio objeto da pesquisa, ou seja, pretende-se conhecer o caso em profundidade, sem a preocupação com o desenvolvimento de alguma teoria. O estudo de caso instrumental é aquele desenvolvido com o propósito de auxiliar no conhecimento ou redefinição de determinado problema. Ou seja, não se tem interesse específico no caso, mas reconhece-se que pode ser útil para alcançar determinados objetivos. E o estudo de caso coletivo é aquele com propósito de estudar características de uma população.

Nesta dissertação, o estudo de caso realizado é do tipo instrumental, segundo classificação de Stake (2000) apud Gil (2007), pois tem o propósito de auxiliar no conhecimento ou redefinição de determinado problema, sendo que o caso da empresa analisada é útil para checar as análises realizadas na primeira parte da dissertação.

Segundo Goode e Hatt (1969) apud Harrison (2006), o método do estudo de caso "não é uma técnica específica. É um meio de organizar dados sociais preservando o caráter unitário do objeto social estudado". Segundo Tull e Hawkins (1976) apud 
Harrison (2006), "um estudo de caso refere-se a uma análise intensiva de uma situação particular" e Bonoma (1985) apud Harrison (2006) destaca que o "estudo de caso é uma descrição de uma situação gerencial".

Segundo Gil (2007), os estudos de caso podem ser constituídos tanto de um único quanto de múltiplos casos. A utilização de um único caso é aplicável quando o caso estudado é único, extremo ou quando o acesso a múltiplos casos é difícil e o pesquisador tem possibilidade de investigar um deles. Nesta hipótese, segundo Gil (2007), a pesquisa deve ser reconhecida como exploratória.

Nesta dissertação, o estudo de caso analisado foi realizado com um único caso, pois o assunto investigado é complexo e depende de amplo acesso a informações, que normalmente não são acessíveis. A opção pelo estudo de um único caso deve-se a facilidade do pesquisador em acessar informações referentes ao caso em questão.

O estudo de caso foi realizado em uma empresa onde foi implantado um EGP. Por razões de confidencialidade, não é apresentado o nome da empresa, a qual será chamada genericamente de "LogB". Esta empresa atua no segmento de logística e transporte, sendo líder de seu setor no Brasil. É parte de uma holding nacional de economia mista sob o controle do governo brasileiro.

A empresa estudada foi escolhida pelo fato de o autor da dissertação ter participado da implantação do EGP desta empresa, desde seu início até o momento da elaboração desta dissertação. Portanto, faz-se uso nesta dissertação de dados obtidos através de observação participante. A observação participante é definida por Yin (2005) como uma modalidade de observação na qual o observador não é apenas um observador passivo, e sim, pode assumir uma variedade de funções dentro do estudo de caso e participa, de fato, dos eventos que estão sendo estudados. A vantagem de utilizar um observador participante é poder participar de decisões e entender todo o contexto no qual as decisões foram tomadas, coisa difícil de se conseguir de um observador externo.

Outros motivos pelos quais a empresa analisada foi escolhida são: 
> A empresa é de grande porte, nacional e em processo de expansão;

O EGP implantado atende a toda a companhia, desempenhando muitas funções;

O EGP implantado está inserido em ambiente sujeito a um grande número de variáveis de ordem organizacional e cultural, possibilitando vários tipos de análises e verificação de fatores críticos de sucesso;

Dos métodos de pesquisa existentes, Yin (2005) considera o estudo de caso como o "irmão mais fraco", em função de suas investigações possuírem precisão, objetividade e rigor insuficientes. Tull e Hawkins (1976) apud Harrison (2006) acreditam que fatores como o reduzido tamanho da amostra, sua seleção não randômica, a falta de similaridade em alguns aspectos da situação problema e a natureza subjetiva do processo de medida ajudam a limitar sua precisão. Yin (2005) complementa lembrando que o estudo de caso fornece uma pequena base para generalizações científicas, uma vez que se limita ao estudo de um ou poucos casos.

Como forma de diminuir os aspectos limitadores do estudo de caso, Yin (2005) lembra da importância em definir com precisão as questões da pesquisa. Segundo Philliber, Schwab e Samloss (1980) apud Harrison (2006), a definição da pesquisa deve tratar os seguintes problemas: "quais questões estudar, quais dados são relevantes, quais dados coletar e como analisar os resultados". Dessa forma, complementa Yin (2005), tenta-se evitar a situação em que as evidências obtidas não remetam às questões iniciais da pesquisa.

Os fatores que serão buscados no estudo de caso são os mesmos desenvolvidos na parte da pesquisa bibliográfica, conforme acima citado. Dessa forma se busca identificar e analisar criticamente os fatores considerados na fase de planejamento da criação do EGP do caso estudado, confrontado-os com os identificados na primeira parte da pesquisa (Pesquisa Bibliográfica).

As evidências utilizadas para o levantamento das informações do estudo de caso foram: documentação do planejamento realizado para a implantação do EGP, entrevistas e observação direta. 
A observação direta foi utilizada pois o autor da dissertação participou da implantação do EGP desta empresa desde seu início e teve acesso a toda informação e documentação produzida pelo EGP, participando inclusive da elaboração do planejamento estratégico deste EGP.

Para evitar o problema de poder haver pontos de vista tendenciosos, realizaram-se entrevistas com 09 participantes da equipe de implantação do EGP e mais 03 profissionais de outras áreas que podem ser entendidos como clientes do EGP implantado. Entre a equipe do EGP, foram consultados o gerente geral, dois gerentes, dois coordenadores, dois líderes de equipes, um consultor de planejamento e um profissional de planejamento. Entre os clientes, foram consultados um coordenador de departamento, um líder de equipe e um profissional de planejamento.

As entrevistas foram realizadas pessoalmente pelo autor, de maneira informal, sem a utilização de questionário. O intuito das entrevistas foi extrair as opiniões dos entrevistados sobre os pontos positivos e negativos da implantação, onde houve erros e acertos e o que poderia ser feito para melhorar o processo.

As análises críticas presentes neste estudo de caso foram realizadas aproximadamente dois anos após o início das primeiras atividades de planejamento da implantação deste EGP. 


\section{FUNDAMENTOS TEÓRICOS}

Neste capítulo são apresentados os fundamentos teóricos que dão base às análises objeto desta dissertação. São incluídas neste capítulo, além da revisão bibliográfica, as análises críticas realizadas pelo autor.

Inicialmente é apresentada uma visão geral sobre o que é o Escritório de Gerenciamento de Projetos (EGP). Em seguida são definidas as etapas de implantação de um EGP e, em seqüência, são apresentadas as características do planejamento estratégico do EGP e do planejamento de suas fases. O capítulo conclui com os processos de implantação e operação do EGP.

\subsection{VISÃO GERAL DO ESCRITÓRIO DE GERENCIAMENTO DE PROJETOS}

A definição do Escritório de Gerenciamento de Projetos (EGP) é amplamente discutida entre os estudiosos do assunto, sendo que cada autor define de forma particular a sua visão do que é um EGP.

Na Tabela 1 são apresentadas as definições de EGP segundo alguns autores:

\begin{tabular}{|c|c|}
\hline Autor & Definição \\
\hline $\begin{array}{l}\text { Rad e } \\
\text { Raghavan } \\
(2000)\end{array}$ & $\begin{array}{l}\text { EGP é uma entidade organizacional que provê foco institucional nos } \\
\text { procedimentos de gerenciamento de projetos. O EGP funciona como } \\
\text { um mecanismo que permite a continuidade organizacional das } \\
\text { experiências e lições aprendidas em gerenciamento de projetos, além } \\
\text { de realizar atividades ligadas ao desenvolvimento de políticas, } \\
\text { procedimentos, treinamentos, ferramentas e consultoria em gestão de } \\
\text { projetos. }\end{array}$ \\
\hline
\end{tabular}

Tabela 1: Definições de EGP (continua)

(Fonte: autor) 


\begin{tabular}{|c|c|}
\hline Autor & Definição \\
\hline $\begin{array}{l}\text { Patah, } \\
\text { Carvalho e } \\
\text { Laurindo } \\
\text { (2003) }\end{array}$ & $\begin{array}{l}\text { EGP é uma estrutura organizacional de projetos o qual se } \\
\text { responsabiliza pela aplicação dos conceitos de gestão de projetos } \\
\text { dentro de uma organização. Esta estrutura pode se apresentar das } \\
\text { mais diferentes formas: desde um simples setor para dar suporte ao } \\
\text { gerenciamento de projetos até um importante departamento onde } \\
\text { todos os projetos da empresa são gerenciados. }\end{array}$ \\
\hline $\begin{array}{l}\text { Ward (2000) } \\
\text { apud Dai e } \\
\text { Wells (2004) }\end{array}$ & $\begin{array}{l}\text { EGP é uma entidade organizacional estabelecida para auxiliar } \\
\text { gerentes de projetos, times e vários níveis gerenciais em assuntos } \\
\text { estratégicos e em implementar princípios, práticas, metodologias, } \\
\text { ferramentas e técnicas de gerenciamento de projetos. }\end{array}$ \\
\hline $\begin{array}{l}\text { Englund, } \\
\text { Graham e } \\
\text { Dinsmore } \\
\text { (2003) }\end{array}$ & $\begin{array}{l}\text { EGP consiste num time dedicado a melhorar a prática de } \\
\text { gerenciamento de projetos na organização. Esta melhora no } \\
\text { desempenho organizacional seria alcançada fazendo da gestão de } \\
\text { projetos uma prática de gestão padronizada e trabalhando no } \\
\text { sentido de mover a organização para um conceito de "enterprise } \\
\text { project management (EPM)". Segundo os autores, EPM significa } \\
\text { fazer toda a gestão da empresa por projetos; todas as atividades da } \\
\text { empresa seriam transformadas em projetos. }\end{array}$ \\
\hline PMI (2004) & $\begin{array}{l}\text { EGP é um "corpo ou entidade organizacional à qual são atribuídas } \\
\text { várias responsabilidades relacionadas ao gerenciamento } \\
\text { centralizado e coordenado de projetos sob o seu domínio. As } \\
\text { responsabilidades de um EGP podem variar desde o fornecimento } \\
\text { de funções de suporte ao gerenciamento de projetos até o } \\
\text { gerenciamento direto de um projeto". }\end{array}$ \\
\hline $\begin{array}{l}\text { Block e Frame } \\
(1998)\end{array}$ & $\begin{array}{l}\text { O EGP é uma constituição de profissionais de gerenciamento de } \\
\text { projetos que servem suas organizações nas necessidades de } \\
\text { gerenciamento de projetos. }\end{array}$ \\
\hline
\end{tabular}

Tabela 1: Definições de EGP (continuação)

(Fonte: autor) 
Analisando as definições apresentadas, observa-se que são todas muito parecidas, diferenciando-se basicamente na composição das funções e responsabilidades que cada autor atribui à sua visão de EGP.

Verzuh (2005) consegue resumir satisfatoriamente as várias definições sobre o EGP. Para ele, o EGP pode ser implementado das mais variadas formas, mas os dois fatores que governam as regras de um EGP são "responsabilidade" e "autoridade". Dessa forma é possível criar uma grande variedade de combinações (responsabilidade $\mathrm{x}$ autoridade), cada uma delas servindo para necessidades específicas da empresa.

Como a possibilidade de combinações de responsabilidade e autoridade é grande, é natural haver dificuldade em resumir numa única definição todas as formas possíveis nas quais os EGP podem ser formados nas empresas. Essa dificuldade é percebida por autores como Casey e Peck (2001) os quais relatam que o EGP significa coisas diferentes para diferentes pessoas, com somente uma única coisa comum a todos: é alguma coisa que está vindo para consertar os problemas de projetos. Reforçam ainda que diferentes EGP resolvem diferentes problemas, e que não há uma configuração que solucione todos os problemas.

Desouza e Evaristo (2006) complementam afirmando que não é possível obter uma definição universal de EGP, porque desenvolver um EGP é um exercício de customização e esforço contínuo. Para estes autores, um EGP pode variar fortemente de tamanho, estrutura e responsabilidade e, portanto, não haveria uma receita para estabelecê-lo. Afirmam ainda que o único critério para o sucesso do EGP é que sua estrutura esteja fortemente alinhada a cultura organizacional da empresa.

Uma pesquisa realizada por Hobbs e Aubry (2007) com 500 empresas de todo mundo entre os anos de 2005 e 2007 conseguiu demonstrar que os EGP variam significativamente em termos de estrutura, funções e valor agregado percebido de uma organização para outra. 
Uma outra característica importante dos EGP é comentada por Andersen, Henriksen e Aarseth (2006). Segundo eles, normalmente os EGP se desenvolvem numa estrutura dinâmica no decorrer do tempo. Isto estaria relacionado com a maturidade em gestão de projetos da empresa. A idéia básica é que você precisa aprender primeiro a engatinhar para depois aprender a andar. Ou seja, iniciando de forma simples e depois expandindo para atividades mais complexas. Segundo os autores, esta evolução aconteceria principalmente nas responsabilidades atribuídas ao EGP, ao seu tamanho e recursos humanos, localização organizacional e nível de autoridade do EGP.

Somando a estas características, Crawford (2002) considera que a implantação de um EGP não é uma tarefa simples, pois trata-se de lidar com pessoas. A implantação consiste na construção de novos processos, criar novas formas de tratar os problemas, integrar atividades entre departamentos, coordenar equipes de trabalho de diferentes tamanhos, com tecnologias, complexidades e negócios variados. Para tudo isso é necessário negociar com pessoas. Portanto, Crawford (2002) reforça que, antes de tudo, a implantação de um EGP é um processo de mudança de cultura organizacional.

Resumindo, as características básicas do EGP são:

$>$ O EGP consiste em um time dedicado a melhorar a prática de gerenciamento de projetos na organização (Englund, Graham e Dinsmore, 2003);

> Todos os EGP possuem uma coisa em comum: é alguma coisa que está vindo para consertar os problemas de projetos (Casey e Peck, 2001);

$>$ Um EGP é formado pelos seus diferentes graus de responsabilidade e autoridade (Verzuh, 2005);

$>$ A definição da estrutura de um EGP, bem como sua implantação, é um exercício de customização e esforço contínuo (Desouza e Evaristo, 2006);

$>$ O EGP se desenvolve em uma estrutura dinâmica no decorrer do tempo, relacionada com a maturidade em gestão de projetos da empresa (Andersen, Henriksen e Aarseth, 2006);

$>$ O EGP deve necessariamente estar alinhado à cultura organizacional da empresa (Desouza e Evaristo, 2006); 
> Os EGP variam significativamente de uma organização para outra no que diz respeito à sua estrutura, funções e valor agregado percebido (Hobbs e Aubry, 2007);

> A implantação de um EGP equivale a um processo de mudança de cultura organizacional, pois todas suas ações estão de alguma forma relacionada à negociação com pessoas (Crawford, 2002).

Um outro aspecto interessante no universo dos EGP é a grande variedade de nomes que são dados a esta entidade organizacional. Segundo a pesquisa de Hobbs e Aubry (2007), os nomes mais utilizados para designar essa entidade organizacional são mostrados na Tabela 2.

\begin{tabular}{|l|l|c|}
\hline \multicolumn{1}{|c|}{ Inglês } & \multicolumn{1}{c|}{ Português } & Porcentagem \\
\hline Project Management Office & Escritório de Gerenciamento de Projetos & $59 \%$ \\
\hline Program Management Office & $\begin{array}{l}\text { Escritório de Gerenciamento de } \\
\text { Programas }\end{array}$ & $12 \%$ \\
\hline Project Support Office & Escritório de Suporte a Projetos & $7 \%$ \\
\hline $\begin{array}{l}\text { Name containing the term "project" } \\
\text { and somewhat similar to project } \\
\text { management office (e.g., project } \\
\text { department) }\end{array}$ & $\begin{array}{l}\text { Nome contendo o termo "projeto" ou algo } \\
\text { similar a escritório de gerenciamento de } \\
\text { projetos (ex., departamento de projetos) }\end{array}$ & $4 \%$ \\
\hline Project Office & Escritório de Projetos & $2 \%$ \\
\hline Center of Excellence & Centro de Excelência & $2 \%$ \\
\hline No name & Sem nome & $2 \%$ \\
\hline $\begin{array}{l}\text { Other (a great variety with none } \\
\text { greater than 1\%) }\end{array}$ & $\begin{array}{l}\text { Outros (grande variedade com nenhum } \\
\text { maior que 1\%) }\end{array}$ & $12 \%$ \\
\hline
\end{tabular}

Tabela 2: Nomes de Entidades Organizacionais

(Fonte: autor, adaptado de Hobbs e Aubry, 2007)

Dois dados são interessantes nesta tabela. O primeiro é que $2 \%$ dos respondentes da pesquisa de Hobbs e Aubry (2007) descrevem uma entidade que existe na organização, mas não tem nome oficial, e, consequentemente, não aparece na estrutura organizacional. Segundo Hobbs e Aubry (2007), isso pode acontecer porque esta entidade pode ter sido criada para preencher uma necessidade real, mas ainda não foi formalizada; ou também, por causa de uma fracassada tentativa 
anterior de implementar o EGP, alguns dirigentes preferem manter a estrutura sem muita ostentação (low profile).

O outro ponto interessante está relacionado a utilização do termo EGP para designar entidades organizacionais voltadas para atendimento a um único projeto ou para múltiplos projetos. Segundo Hobbs e Aubry (2007), o termo Escritório de Projetos (Project Office em inglês) é aplicado para EGP que atendem a um único projeto. Kerzner (2001a) concorda com este critério, completando que usualmente o Project Office é utilizado para gerenciar um grande projeto e é definido como sendo a parte integrante do time do projeto que tem a responsabilidade pelo suporte às tarefas do gerente de projetos, sendo que sua maior responsabilidade é realizar a integração dos trabalhos entre as gerências funcionais da organização. Segundo Hobbs e Aubry (2007), na Tabela 2 foram considerados apenas os casos onde o termo Project Office foi utilizado para estruturas responsáveis por múltiplos projetos.

Esta dissertação é focada no estudo dos EGP responsáveis por múltiplos projetos.

O item seguinte analisa quais são as etapas necessárias para se implantar um EGP.

\subsection{AS ETAPAS DE IMPLANTAÇÃO DE UM EGP}

A implantação de um Escritório de Gerenciamento de Projetos é uma tarefa complexa e que envolve riscos. Como o EGP varia significativamente de uma organização para outra, sua implantação exige ser customizada para a empresa onde será implantado.

De uma forma genérica, conforme apresentado na Figura 3 , as etapas para implantação de uma estrutura similar a um EGP envolvem as etapas de planejar sua implantação, para posteriormente implantá-lo e operá-lo.

Nesta dissertação, o foco das análises críticas é a etapa de planejar a implantação do EGP. Os itens seguintes discutem a importância da etapa de planejamento e as etapas necessárias para se implantar um EGP. 


\subsubsection{O Processo de Planejamento}

A etapa mais importante para a criação de uma estrutura do tipo de um EGP referese ao planejamento de sua implantação. Esta etapa é a que dará as bases para uma implantação que poderá atingir os objetivos esperados pela companhia com a implantação de um EGP.

Para Steiner (1969) apud Oliveira (2002), o planejamento no campo da administração é composto por cinco dimensões, os quais não são mutuamente exclusivas nem representam linhas demarcatórias muito claras:

A primeira corresponde ao assunto abordado: produção, pesquisa, novos produtos, finanças, marketing, instalações, recursos humanos, etc.;

> A segunda corresponde aos elementos do planejamento: propósitos, objetivos, estratégias, políticas, programas, orçamentos, normas e procedimentos, entre outros;

$>$ A terceira corresponde à dimensão do tempo do planejamento: curto, médio e longo prazo;

> A quarta corresponde às unidades organizacionais onde o julgamento é elaborado: corporativo, subsidiárias, grupos funcionais, divisões, departamentos, produtos, etc.;

> A quinta corresponde às características do planejamento: complexidade ou simplicidade, qualidade ou quantidade, estratégico ou tático, confidencial ou público, formal ou informal, econômico ou caro.

Dessa forma, Oliveira (2002) conceitua planejamento como um processo, considerando os aspectos abordados pelas dimensões apresentadas, desenvolvido para o alcance de uma situação desejada de um modo mais eficiente ${ }^{2}$, eficaz ${ }^{3}$ e efetivo $^{4}$, com a melhor concentração de esforços e recursos da empresa. Deve procurar maximizar os resultados e minimizar as deficiências.

\footnotetext{
${ }^{2}$ Eficiência: fazer as coisas de maneira adequada (Oliveira, 2002).

${ }^{3}$ Eficácia: fazer as coisas certas (Oliveira, 2002).

4 Efetividade: manter-se no ambiente e apresentar resultados globais positivos ao longo do tempo, permanentemente (Oliveira, 2002).
} 
Para Oliveira (2002), o processo de planejar envolve um modo de pensar. E um salutar modo de pensar envolve indagações. Estas indagações envolvem questionamentos sobre o que fazer, como, quando, para quem, por que, por quem e onde.

Para Ackoff (1974) apud Oliveira (2002) existem cinco aspectos do planejamento no campo da administração que devem ser sempre considerados:

> Planejamento dos fins: especificação do estado futuro desejado, ou seja, a missão, propósitos, objetivos e metas;

> Planejamento dos meios: proposição de caminhos para a empresa chegar ao estado futuro desejado;

> Planejamento organizacional: esquematização dos requisitos organizacionais para poder realizar os meios propostos;

> Planejamento dos recursos: dimensionamento de recursos humanos e materiais, determinação da origem e aplicação dos recursos financeiros;

> Planejamento da implantação e controle: corresponde à atividade de planejar o gerenciamento da implantação.

Considerando os grandes níveis hierárquicos, Oliveira (2002) apresenta três tipos de planejamento no campo da administração:

Planejamento Estratégico: é o processo administrativo que proporciona sustentação metodológica para se estabelecer a melhor direção a ser seguida. Normalmente é de responsabilidade dos níveis mais altos da empresa e diz respeito tanto à formulação de objetivos quanto à seleção dos cursos de ação a serem seguidos para sua consecução, levando em conta as condições externas e internas à empresa e sua evolução esperada. Refere-se à eficácia do planejamento;

> Planejamento Tático: tem por objetivo otimizar determinada área de resultado e não a empresa como um todo, trabalhando com a decomposição dos objetivos, estratégias e políticas estabelecidas no planejamento estratégico. São normalmente desenvolvidos em níveis organizacionais inferiores, tendo como principal finalidade a utilização eficiente dos recursos disponíveis para a 
consecução dos objetivos fixados. Refere-se aos meios para se atingir os objetivos e a sua eficiência;

> Planejamento Operacional: é a formalização das metodologias de desenvolvimento e implantação estabelecidas, através de planos de ação ou planos operacionais. Devem conter os recursos necessários, procedimentos básicos, produtos ou resultados finais esperados, prazos estabelecidos e os responsáveis pela sua execução.

Portanto, nesta dissertação, os conceitos do processo de planejamento no campo da administração serão utilizados para analisar o processo de planejamento da implantação de um EGP.

No item seguinte são discutidos os processos necessários para constituição de um EGP e situado o processo de planejamento dentro de todo o processo de constituição de um EGP.

\subsubsection{Etapas de Implantação de um EGP}

A implantação do EGP pode ser tratada como a implantação de um projeto. Como tal, todas as atividades ligadas à gestão de projetos podem a ela serem aplicadas (PATAH; CARVALHO, 2003 apud PATAH, 2004).

Conforme comentado anteriormente, Andersen, Henriksen e Aaserth (2006) lembram que o EGP deve ser desenvolvido numa estrutura dinâmica no decorrer do tempo e relacionado com a maturidade em gestão de projetos da empresa. Isto sugere a aplicação de fases no processo de implantação do EGP. A idéia básica é iniciar de forma simples e depois expandir para atividades mais avançadas. Relembrando, os autores afirmam que normalmente esta evolução acontece sobre os seguintes fatores: responsabilidades, tamanho, recursos humanos, localização organizacional e nível de autoridade. 
Crawford (2002) complementa que a abordagem para implantação do EGP deve gerar valor ao negócio o mais rapidamente possível. Para tanto, a chave é manter a implementação simples com um plano de implantação bem estruturado.

Autores encontrados na revisão bibliográfica apresentam propostas de planos de implantação de EGP, porém, baseados na visão particular de cada um sobre as funções que devem existir em um EGP, oferecendo uma fórmula padronizada para todas as situações.

Para Englund, Graham e Dinsmore (2003), as etapas da implantação de um EGP são: criar as condições para a mudança, implementar a mudança e re-congelar a situação.

Outra forma é apresentada por Crawford (2002), o qual divide o processo em quatro etapas: estabelecer a base, começar com iniciativas de curto prazo, caminhar com soluções de longo prazo, manter e melhorar.

Block e Frame (1998) consideram as etapas da Figura 4 as correspondentes para implantação de um EGP. Após uma avaliação da situação atual, é elaborado um planejamento que constitui em identificar o patrocinador, definir as funções e a equipe, preparar um plano de comunicação e orçamento. Após isto são obtidos os recursos, conduzido um processo piloto e então inicia-se a implantação.

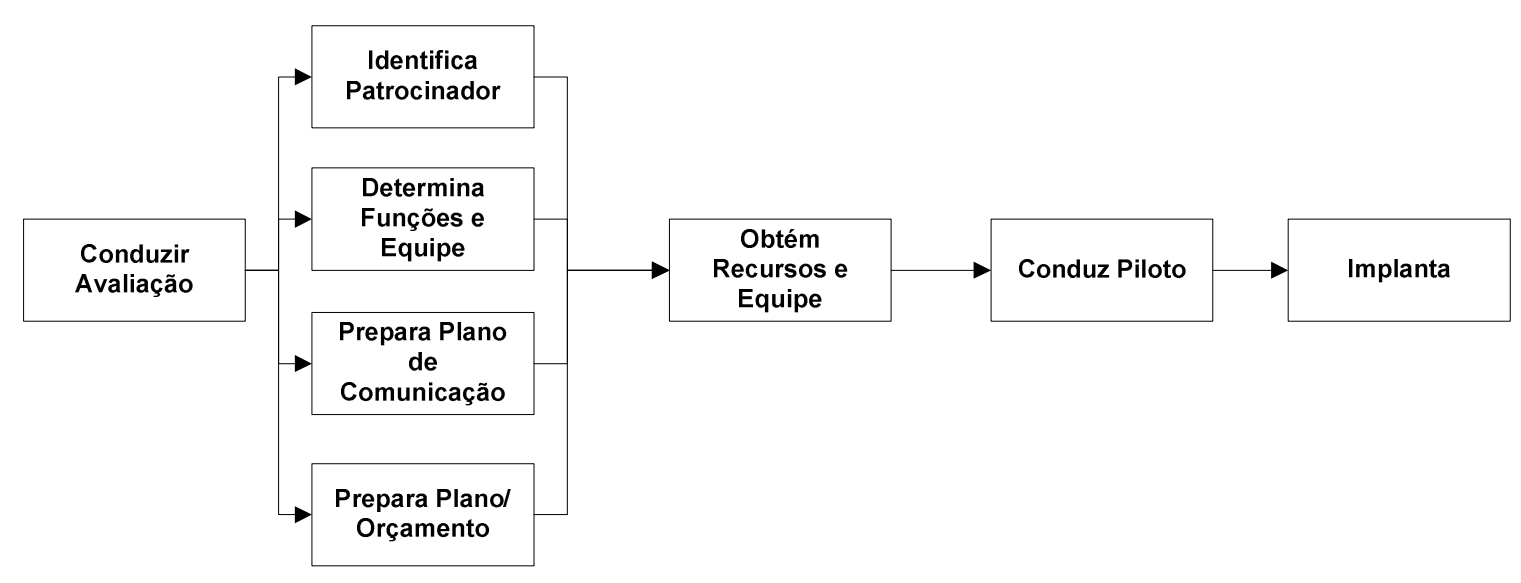

Figura 4: Implantação de um EGP

(Fonte: Block e Frame, 1998) 
No intuito de apresentar um método genérico que pudesse ser aplicado a todas as situações, o autor dessa dissertação propõe um método baseado na Figura 5.

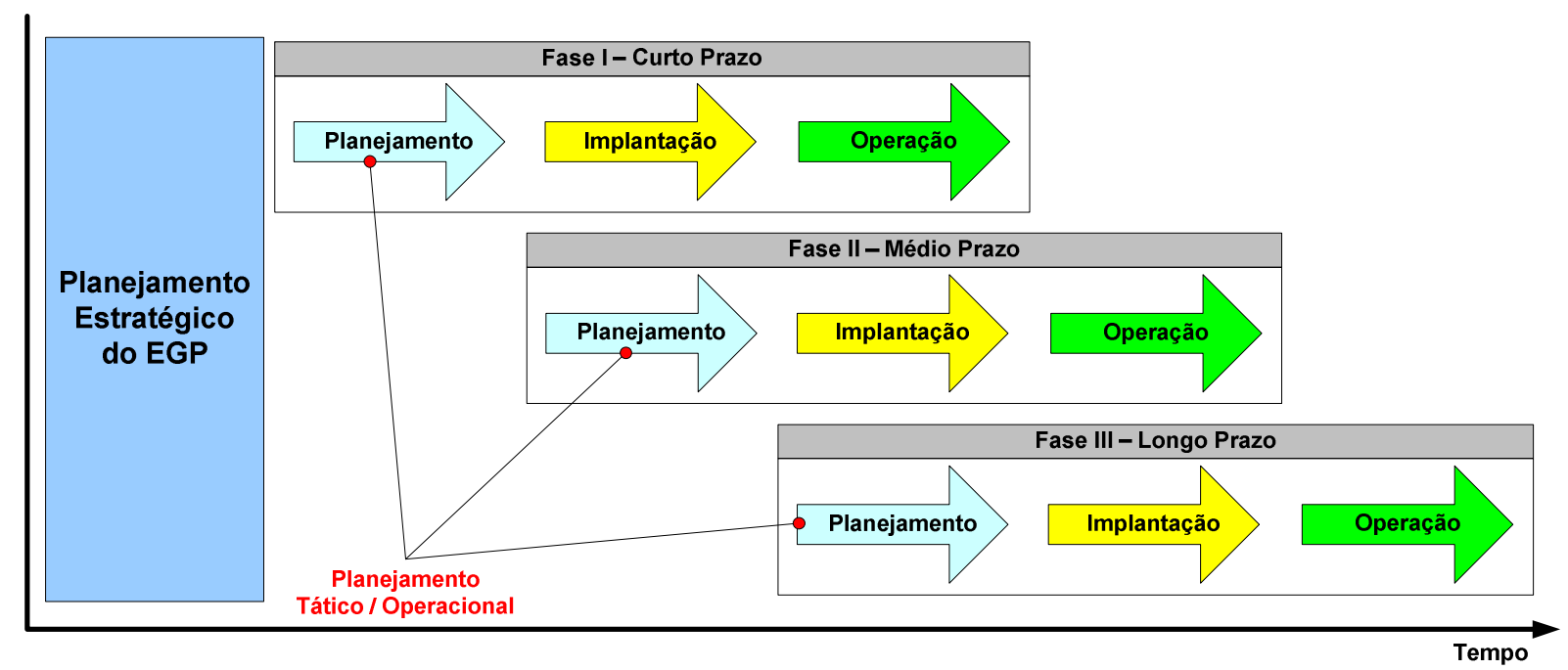

Figura 5: Etapas para implantação de um EGP

(Fonte: autor)

O processo é constituído de duas partes: o planejamento estratégico do EGP e o planejamento tático / operacional do EGP, sendo este sub-dividido em fases.

O trabalho inicial é realizar o planejamento estratégico de toda a implantação do EGP, definindo os objetivos de curto, médio e longo prazo. São analisados os problemas a serem tratados, verificadas as condições para implantação do EGP, definidas as funções e a autoridade do EGP, é identificado o patrocinador que dará o apoio necessário da alta administração e são analisadas as influências de fatores como a maturidade e a cultura organizacional na implantação do EGP.

A distribuição dos objetivos ao longo do tempo gerará as fases da implantação. Nestas fases, deve ser realizado o planejamento tático / operacional, onde então o planejamento deve ser refinado, definindo os detalhes necessários para que cada objetivo seja alcançado, e elaborado o plano de implantação (plano de projeto) da respectiva fase. Neste plano de projeto deverão constar detalhadamente as atividades necessárias para atingir os objetivos da respectiva fase, indicando os responsáveis e os prazos a serem cumpridos. 
Os próximos itens analisam, respectivamente, o planejamento estratégico para a implantação do EGP e o planejamento detalhado das fases mencionadas na Figura 5.

\subsection{O PLANEJAMENTO ESTRATÉGICO DO EGP}

A etapa mais importante para estabelecer o Escritório de Gerenciamento de Projetos é a elaboração de seu planejamento estratégico. É este instrumento que guiará todo o processo de implantação e mostrará o rumo e os objetivos que devem ser perseguidos e alcançados. Segundo Oliveira (2002), o planejamento estratégico pode ser definido como um processo contínuo que visa estabelecer um estado futuro desejado, com a melhor concentração de esforços e recursos pela empresa. Para Kerzner (2003), o planejamento estratégico do EGP envolve determinar onde se gostaria de chegar no futuro e, então, elaborar o plano para chegar lá.

Os pontos essenciais que devem constar do planejamento estratégico do EGP são:

> Diagnóstico da situação atual e identificação dos problemas a serem resolvidos;

> Definição dos benefícios esperados;

> Verificação das condições de viabilidade para implantação;

> Definição da visão, missão, abrangência, princípios e valores do EGP;

> Alinhamento dos objetivos do EGP com os da organização;

$>$ Definição dos objetivos de curto, médio e longo prazo para o EGP;

$>$ Definição das funções do EGP;

> Definição da autoridade e posicionamento do EGP na estrutura organizacional;

> Análise da influência da cultura organizacional;

> Análise da influência da maturidade em gestão de projetos;

> Análise da influência dos fatores críticos de sucesso;

$>$ Estimativa dos recursos e custos envolvidos;

Para tanto, Rabechini, Carvalho e Laurindo (2002) lembra que os objetivos do planejamento estratégico definidos para o EGP devem estar alinhados aos objetivos da organização. 
Desouza e Evaristo (2006) também lembram que todas essas definições devem estar alinhadas com a cultura organizacional da empresa. Kerzner (2002) informa que o planejamento estratégico é um processo dinâmico, que necessita de reavaliações, feedback e atualizações. Portanto, os reflexos e resultados obtidos durante o processo de implantação de cada fase devem provocar revisões e adequações no planejamento estratégico elaborado.

Nos itens seguintes são discutidos cada um dos aspectos acima listados.

\subsubsection{Diagnóstico da Situação Atual}

Para Oliveira (2002) a determinação do diagnóstico estratégico de uma empresa significa determinar "como se está" esta empresa. Para a realização da implantação de um EGP em uma empresa, é necessário identificar qual a situação da sua gestão de projetos no momento. Crawford (2002) também reforça esta necessidade.

É necessário identificar quais são os problemas de gestão de projetos que ocorrem na empresa e quais as conseqüências estes problemas estão gerando. Assim é possível identificar quais são os maiores, principais e mais urgentes problemas que a empresa deve buscar resolver. A implantação do EGP deverá ter o intuito de buscar sanar estes problemas.

A seguir são listados os problemas mais comuns que ocorrem com a gestão de projetos, programas ou portfólios nas empresas:

> Baixa eficiência no controle e execução dos projetos, programas e portfólios;

> Projetos concluídos acima dos custos e prazos estimados;

> Projetos concluídos fora da especificação ou sem a qualidade esperada;

$>$ Excesso de alterações de escopo;

> Falta de padronização na forma de planejamento, execução e avaliação dos projetos e, consequentemente, da gestão de projetos;

> Má utilização dos recursos dos projetos; 
> Comunicação ineficiente entre os vários stakeholders do projeto e da empresa;

> Planejamento do projeto realizado de forma ineficiente;

> Lucratividade abaixo da estimada;

> Baixa produtividade dos recursos (materiais e humanos);

> Ferramentas de gestão sem padronização;

> Falta de aderência do projeto com os objetivos estratégicos da empresa;

> Falta de priorização dos projetos;

> Falta de treinamento e capacitação da equipe em gestão de projetos;

> Cultura organizacional resistente à aplicação da gestão de projetos;

> Falta de base de dados sobre os projetos da empresa;

> Falta de uma base de dados do histórico dos projetos da empresa;

> Falta de documentação e gerenciamento da base de lições aprendidas;

> Falta de documentação e gerenciamento de uma base de riscos;

> Má definição das responsabilidades dentro do projeto;

> Falta de um responsável único pelo projeto;

$>$ Integração entre as gerências funcionais ineficiente;

> Necessidade de controlar vários projetos simultaneamente;

$>$ Necessidade de controlar múltiplos fornecedores simultaneamente;

> Necessidade de prover relatórios consolidados de vários projetos;

$>$ Necessidade de prover uma fonte única de comunicação com os clientes.

É necessário, portanto, que a empresa identifique quais destes problemas, e eventualmente outros, que afligem a companhia, pois a estrutura do EGP deve ser montada para resolver estes problemas.

\subsubsection{Benefícios Esperados}

A implantação de um EGP não gera benefícios pré-definidos. Os benefícios gerados estão relacionados com a responsabilidade que foi transferida ao EGP para resolver cada um dos problemas identificados no item do diagnóstico da situação atual (item anterior). 
Um EGP é implantado em uma empresa com o intuito de resolver os problemas que ocorrem com a sua gestão de projetos, programas ou portfólios. Portanto, devem ser definidos com clareza quais os problemas que ficarão sob a responsabilidade de resolução por parte do EGP e se montar uma estrutura apropriada para a resolução destes problemas.

Dessa forma, os benefícios e vantagens esperados com a existência do EGP virão da capacidade do EGP em resolver estes problemas.

Ainda assim, o valor que um EGP pode gerar a organização varia dependendo do tipo de problema que ficará sob sua responsabilidade. Segundo Gonzáles e Rodrigues (2002), quanto mais próximo do estratégico estiver o foco de atuação do EGP, maior será o seu valor para a organização, conforme ilustra a Figura 6. Dessa forma, estando mais próximo da visão estratégica do negócio, maior valor será adicionado à organização, pois o foco de atuação será a maximização do valor da empresa e da taxa de sucesso de suas iniciativas estratégicas. Enquanto que quanto mais próximo do operacional, maior será o foco na redução de custos e na melhoria da execução.

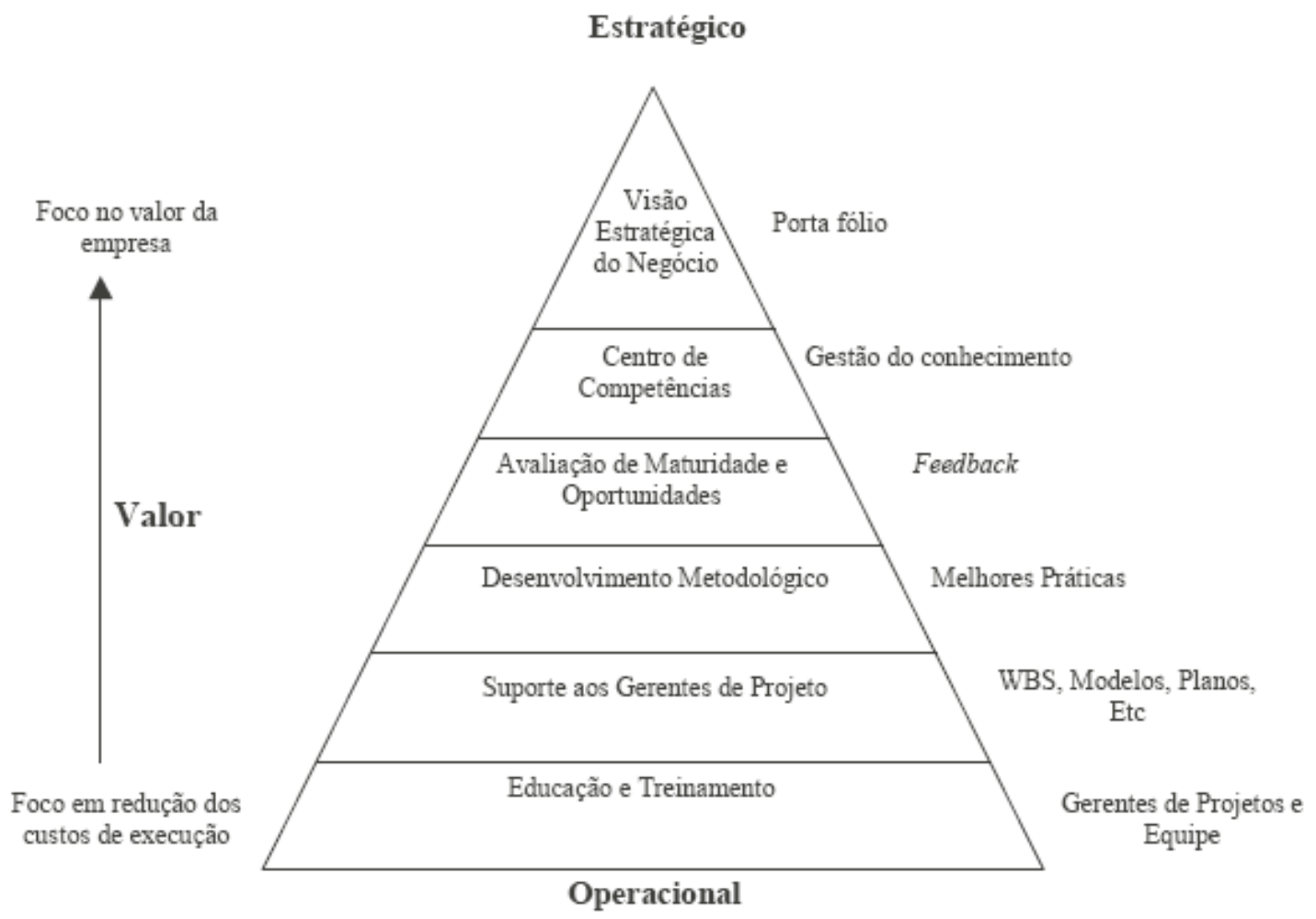

Figura 6: Relação entre foco de atuação e valor para a empresa

(Fonte: Gonzáles e Rodrigues, 2002) 
Block e Frame (1998) ainda lembram que a implantação de um EGP oferece valor tanto para os membros da equipe como para o cliente. Os membros da equipe obterão apoio através de consultoria e treinamentos, o que trará melhoras no seu desempenho. E os clientes enxergarão a implantação como um sinal visível do compromisso da organização com a aplicação da gestão de projetos da melhor maneira possível.

\subsubsection{Condições de Viabilidade para Implantação}

Mesmo com a organização tendo a intenção de transferir ao EGP a responsabilidade por resolver parte ou a totalidade dos problemas identificados no diagnóstico da situação atual, deve se ter o cuidado de verificar se há condições viáveis na empresa para a constituição do EGP. Dinsmore (2002) alerta que pior que rejeitar a idéia de implantar um EGP é querer implantá-lo com expectativas que não sejam realistas.

Dinsmore (2002) associa a implantação de um EGP a um processo de mudança de cultura organizacional. Portanto, as barreiras existentes para a promoção de uma mudança de cultura organizacional também valeriam para a implantação de um EGP. Dinsmore (2002) cita duas dessas barreiras:

> Falta de Pressão Externa: uma mudança é geralmente provocada por uma força externa à organização - tais como mudanças de mercado e pressões por fazer as coisas "mais rápido, mais barato e melhor". Se esta pressão não existe e a companhia se encontra numa rota de sucesso e calmaria, então tentar melhorar as coisas utilizando um EGP provavelmente não dará certo. Kerzner (2001b) também informa que mudanças no estilo de gerenciamento e na cultura organizacional ocorridas durante épocas economicamente favoráveis ocorrem de maneira muito lenta.

> Falta de Insatisfação Interna: se houver pressão externa à empresa, as pessoas na organização ficam mais insatisfeitas com o modo atual de trabalho, pois 
sentem que é necessário mudar. Essa insatisfação é muito importante, pois sem ela, a proposta de mudança dos métodos de trabalhos atuais não será levada a sério;

Outro ponto importante é a verificação se já existe na empresa uma massa crítica de pessoas com conhecimento em gestão de projetos e que dão valor a uma implantação de um EGP. A não existência dessa massa crítica poderá provocar uma grande resistência das pessoas à implantação do EGP. Este ponto, porém, deve ser analisado com cuidado, pois caso não exista essa massa crítica, esta poderá ser construída pelo próprio EGP, através de fortes atividades ligadas à capacitação e treinamento das pessoas da organização (TOLEDO; ROVAI, 2002).

Mesmo havendo as condições para implantação do EGP, é necessário ter cuidado para não montar um EGP que traga outros tipos de problemas para a organização. Os problemas mais comuns advindos da implantação de um EGP são, conforme Snyder (2002):

Aumento de custos, vindos das funções de suportar a padronização de procedimentos, ferramentas, treinamentos e desenvolvimento de serviços;

$>$ Aumento da burocracia, diminuindo a agilidade e desempenho dos projetos;

$>$ Aumento dos conflitos de interesse e territorialismo. Alguns profissionais podem ver suas carreiras ameaçadas enquanto outros podem não sentir confiança na nova estrutura ou mesmo se sentirem desprestigiados na organização;

> Dificuldade em manter a atenção e suporte da alta administração acarretando em maiores riscos de obstrução por parte do restante da organização.

Dai e Kwak (2000) complementam que muitos EGP acabam não sendo bem aceitos dentro da organização, sofrendo uma grande pressão para justificar seus investimentos. Essa pressão pode ser forte e associa um alto risco à constituição do EGP. Segundo os autores, as principais razões para esta pressão seriam: as despesas do EGP serem do tipo overhead, os altos custos de implantação e manutenção, o acréscimo de burocracia e a dificuldade de justificar o retorno do investimento. 


\subsubsection{Objetivos Estratégicos}

Para se construir um Escritório de Gerenciamento de Projetos é necessário construir os alicerces que the darão sustentação. E os alicerces de uma organização são compostos por sua visão, missão, abrangência, princípios e valores (COSTA, 2006 e OLIVEIRA, 2002).

Para o planejamento estratégico de um EGP, podem ser aplicados os mesmos fundamentos e conceitos difundidos nas disciplinas ligadas à gestão estratégica. Portanto, os conceitos abaixo apresentados, quando ditos para a "empresa" devem ser entendidos como "para o EGP".

Oliveira (2002) e Costa (2006) propõem um processo para a elaboração dos objetivos estratégicos, tópico fundamental no planejamento estratégico de uma empresa. Associando as recomendações de ambos, é proposta nesta dissertação o processo para elaboração dos objetivos estratégicos de um EGP conforme apresentado na Figura 7.

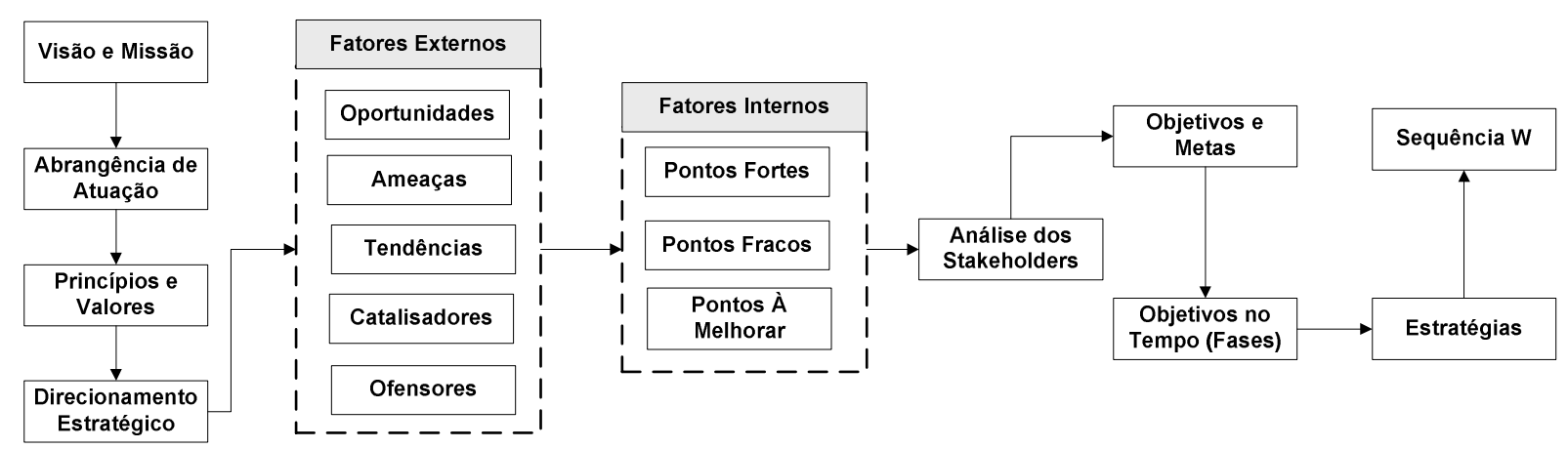

Figura 7: Processo dos Objetivos Estratégicos

(Fonte: autor)

A visão, segundo Costa (2006) e Oliveira (2002), é uma descrição do que a empresa quer ser no futuro, ou seja, uma descrição de como ela se vê ou gostaria de ser vista no futuro. A visão não é um mero sonho, uma utopia, e sim uma situação altamente desejável de uma realidade futura possível. 
Segundo Costa (2006), a visão deve ser definida de forma simples, objetiva e compreensiva, tornado-se assim, útil e funcional para todos os envolvidos. A visão deve ser compartilhada para toda organização, pois sua função é explicitar o que a empresa quer ser, unificar as expectativas, dar um sentido de direção, facilitar a comunicação, ajudar o envolvimento e o comprometimento das pessoas, inspirar as grandes diretrizes e balizar as estratégias.

A missão, segundo Costa (2006), é uma descrição da razão da existência da organização, ou seja, é uma descrição que mostra para o que serve a organização e o que ela pretende suprir. Para Oliveira (2002), a missão determina aonde a empresa quer ir, representando um horizonte dentro do qual a empresa atua ou poderá atuar.

Deve ser definida também a abrangência de atuação do EGP. Segundo Costa (2006), a abrangência descreve as limitações reais ou auto-impostas para atuação da organização. É ela que dá uma concentração, um foco nas ações da organização. Para o caso do EGP, esta abrangência pode definir, por exemplo, o porte ou tipo de projetos em que o EGP atuará ou a divisão da empresa que receberá seus serviços.

Segundo Costa (2006), é importante também definir os princípios e valores a qual a organização se balizará. Os princípios são os pontos e tópicos que a organização não está disposta a mudar, aconteça o que acontecer. Os valores são as características, virtudes e qualidades que são realmente importantes para a organização e, portanto, devem ser preservados e incentivados.

Costa (2006) também lembra da necessidade de definir um direcionamento estratégico às ações da organização. O direcionamento estratégico é um processo que permite selecionar as prioridades em função da gravidade dos problemas enfrentados e estabelecer uma seqüência lógica nos processos de intervenção, começando por aqueles que foram diagnosticados como sendo os mais importantes e mais graves para a organização. 
Dentro deste processo é importante também analisar os efeitos dos fatores externos e internos nas estratégias a serem elaboradas. Nos fatores internos, devem ser analisados os internos ao EGP. Nos fatores externos, devem ser analisados os externos ao EGP (mas ainda dentro da organização) e os externos à organização.

Segundo Costa (2006), os tópicos dos fatores externos a serem analisados são as tendências, os catalisadores, os ofensores, as oportunidades e as ameaças.

As tendências, segundo Costa (2006), são as variações no ambiente externo, lentas ou rápidas, mas persistentes, que podem afetar de forma leve ou profunda os negócios ou as atividades do EGP.

Os catalisadores, segundo Costa (2006), são fatores externos prevalecentes que afetam positivamente e de imediato as atividades da organização. Os ofensores são fatores externos atuais que afetam, de imediato, negativamente, as atividades da organização.

Ainda segundo Costa (2006), as oportunidades são fatores externos previsíveis para o futuro que, se ocorrerem, afetarão positivamente as atividades da empresa ou do EGP. Para Oliveira (2002), as oportunidades são variáveis externas e não controláveis pela empresa, que podem criar condições favoráveis para a empresa, desde que a mesma tenha condições e/ou interesse em usufruí-las.

As ameaças, segundo Costa (2006), são fatores externos previsíveis para o futuro que, se ocorrerem, afetarão negativamente as atividades da empresa ou do EGP. Para Oliveira (2002), as ameaças são variáveis externas e não controláveis pela empresa que podem criar condições desfavoráveis para a mesma.

Para Costa (2006) e Oliveira (2002), os tópicos dos fatores internos a serem analisados são os pontos fortes, pontos fracos e os pontos a melhorar.

Costa (2006) define os pontos fortes como aquelas características positivas de destaque na instituição, que favorecem o cumprimento do seu propósito. Para 
Oliveira (2002), ponto forte é a diferenciação conseguida pela empresa que lhe proporciona uma vantagem operacional no ambiente.

Os pontos fracos, segundo Costa (2006), são as características negativas que prejudicam no cumprimento do seu propósito. Para Oliveira (2002), ponto fraco é uma situação inadequada da empresa que lhe proporciona uma desvantagem operacional no ambiente.

E os pontos a melhorar, segundo Costa (2006), são características positivas que não estão no nível ou grau suficiente para contribuir efetivamente para o cumprimento do seu propósito.

Durante o processo de definição dos objetivos estratégicos, é necessário também realizar uma análise dos stakeholders, termo em inglês para partes interessadas. Segundo Costa (2006), os stakeholders podem ser definidos como qualquer instituição, pessoa, grupo de pessoas, formal ou informal, que tenha algum tipo de interesse que pode afetar ou ser afetado pelo funcionamento, desempenho e resultados da organização ou do EGP. Para cada stakeholder deve ser analisado o que ele espera do EGP, quais seus interesses, como podem afetar positiva ou negativamente e principalmente como atender as suas demandas.

Desta análise dos stakeholders, é importante determinar os possíveis grupos de resistência que o EGP encontrará. Para estes, deverá ser definida ações específicas para minimizar seus impactos. Da mesma forma, é importante também determinar os grupos onde o EGP poderá construir coalizões. Para estes, ações específicas devem ser definidas para viabilizar o mais rápido possível estas coalizões.

No final deste processo, devem estar definidos os objetivos, as metas e as estratégias para a implantação do EGP. Para tanto, é importante ressaltar que estes devem sempre estar alinhados aos objetivos gerais da organização.

Para Oliveira (2002), objetivo é o alvo ou situação que se pretende atingir, determinando assim a direção dos esforços da empresa. E a meta é a quantificação do objetivo. 
Um ponto importante neste processo é a distribuição dos objetivos ao longo do tempo. Conforme sugerido na Figura 5, é necessária a identificação das fases de implantação do EGP. Estas fases são oriundas da definição dos objetivos e metas designadas ao EGP. Uma forma de distribuir no tempo e criar as fases de implantação é, por exemplo, definir objetivos de curto, médio e longo prazo. Neste exemplo haveria três fases de implantação. Com isto, é dado foco e atenção aos principais problemas a serem solucionados. Crawford (2002) reforça esta necessidade, indicando que os objetivos de curto prazo devem ser aqueles que mostrem resultados à organização de forma rápida, ou seja, que seja possível uma rápida implantação e que gerem benefícios claros à organização, de forma a manter os stakeholders interessados na continuação da implantação do EGP.

Crawford (2002) ainda acrescenta que estes objetivos precisam ser: específicos, mensuráveis, acordados entre os stakeholders envolvidos, realistas e limitados no tempo.

Com base nos objetivos e metas estabelecidas, devem ser elaboradas as estratégias. Para Oliveira (2002), a estratégia é a ação ou caminho mais adequado a ser executado para alcançar o objetivo e a meta.

Um cuidado importante a ser tomado é o envolvimento correto das pessoas que participam e decidem os objetivos estratégicos do EGP. Além do envolvimento da alta administração da empresa, a média administração e o nível operacional também devem ser ouvidos, pois eles são diretamente afetados pelas decisões adotadas. Costa (2006) e Oliveira (2002) concordam com a importância que deve ser dada a este assunto. Ambos apresentam uma técnica que permite que se aplique o processo de planejamento estratégico tanto no sentido top-down (de cima para baixo) quanto no sentido bottom-up (de baixo para cima). Costa (2006) deu o nome de "Seqüência W" para esta técnica. Abaixo é descrito os movimentos desta técnica, conforme apresentado por Costa (2006):

"10 movimento: de cima para baixo, de direcionamento e de alinhamento, de sensibilização, de iniciativa da alta administração e da alta gerência"; 
$>$ "2ำ movimento: de baixo para cima, no qual as bases, agora alinhadas, fazem suas reflexões e submetem suas proposições;"

> "3o movimento: de cima para baixo, de decisão e de divulgação, pela alta administração, que examina, consolida e compatibiliza as propostas, toma as decisões e dá conhecimento a todos de suas decisões e determinações;"

"4o movimento: de baixo para cima, de implementação, acompanhamento e realimentação (feedback), no qual as bases colocam em prática aquilo que foi decidido, informando continuamente a alta administração do que está acontecendo."

Nos próximos itens são apresentados outros tópicos que também fazem parte do planejamento estratégico do EGP, como a definição das funções, a estrutura organizacional, os tipos e as influências que afetam o planejamento do EGP.

\subsubsection{Tipos de EGP}

Uma das formas de analisar e estudar os Escritórios de Gerenciamento de Projetos é através do estudo de sua tipologia. A tipologia é formada por modelos ${ }^{5}$, que são necessariamente uma simplificação e redução das complexidades da realidade, sendo muito úteis para suportar pesquisas e estudos (HOBBS; AUBRY, 2007).

Existem várias propostas de tipologia, apresentadas por diferentes autores, os quais supõem que um pequeno número de modelos abrange a utilização na maioria das empresas. Algumas dessas tipologias serão discutidas ainda no decorrer deste item.

Verzuh (2005) revela que a maioria das tipologias existentes é na realidade uma combinação entre as funções e a autoridade designada ao EGP. De fato, cada EGP tratado na literatura é a descrição de uma série de funções com a autoridade e o posicionamento na estrutura organizacional a ele designada.

Dessa forma, cada autor costuma normalmente propor de três a cinco tipos de EGP de múltiplos projetos, organizados de forma ascendente no número de

\footnotetext{
${ }^{5}$ Modelos: são representações organizadas de um dado fenômeno ou processo observado na realidade com elementos constituintes justificados por uma teoria (Oliveira, 2005)
} 
responsabilidades a ele designadas. A passagem de um tipo para outro é dada de forma particular por cada autor, sendo que as mais comuns são relacionadas por Hobbs e Aubry (2007):

Área onde ficam os gerentes de projetos está ou não inclusa dentro do EGP;

$>$ Nível dentro da hierarquia organizacional: do baixo nível operacional ao alto nível administrativo;

> Influência e autoridade: de passivo para ativo em obrigar o uso dos padrões;

$>$ Assuntos operacionais para assuntos estratégicos, freqüentemente associados a uma progressão de gerenciamento de projetos para gerenciamento de programas e/ou portfólios;

> Direcionado a processos para direcionado a negócios;

> Maturidade em gerenciamento de projetos dentro da organização: de uma cultura que não suporta a gestão de projetos para uma cultura que suporta totalmente a gestão de projetos.

Com o intuito de verificar as características acima apresentadas, incluindo a afirmação de Verzuh (2005) de que os tipos de EGP são formados pela composição de suas funções e autoridade, os parágrafos seguintes apresentam e analisam a tipologia apresentada por três autores, apresentada de forma resumida na Tabela 3.

\begin{tabular}{|l|c|c|c|c|c|c|}
\hline Autor & $\begin{array}{c}\text { EGP de um } \\
\text { único } \\
\text { projeto }\end{array}$ & \multicolumn{4}{|c|}{ EGP para Múltiplos Projetos } \\
\hline $\begin{array}{l}\text { Verzuh } \\
(2005)\end{array}$ & $\begin{array}{c}\text { Center of } \\
\text { Excellence }\end{array}$ & $\begin{array}{c}\text { Project } \\
\text { Support } \\
\text { Office }\end{array}$ & $\begin{array}{c}\text { Project } \\
\text { Management } \\
\text { Office }\end{array}$ & $\begin{array}{c}\text { Program } \\
\text { Management } \\
\text { Office }\end{array}$ & $\begin{array}{c}\text { Accountable } \\
\text { Project } \\
\text { Office }\end{array}$ \\
\hline $\begin{array}{l}\text { Dinsmore } \\
(1998)\end{array}$ & $\begin{array}{l}\text { Authonomous } \\
\text { Project Team }\end{array}$ & $\begin{array}{c}\text { Project } \\
\text { Management } \\
\text { Center of } \\
\text { Excellence }\end{array}$ & $\begin{array}{c}\text { Project } \\
\text { Support } \\
\text { Office }\end{array}$ & $\begin{array}{c}\text { Program } \\
\text { Management } \\
\text { Office }\end{array}$ & $\begin{array}{c}\text { Chief } \\
\text { Project } \\
\text { Office }\end{array}$ \\
\hline $\begin{array}{l}\text { Casey e } \\
\text { Peck } \\
(2001)\end{array}$ & & $\begin{array}{c}\text { Control } \\
\text { Tower }\end{array}$ & $\begin{array}{c}\text { Weather } \\
\text { Station }\end{array}$ & $\begin{array}{c}\text { Resource } \\
\text { Pool }\end{array}$ & & \\
\hline
\end{tabular}

Tabela 3: Tipos de EGP

(Fonte: autor, adaptado de Hobbs e Aubry, 2007) 


\section{a) Modelo de Verzuh (2005)}

O modelo de Verzuh (2005) leva em consideração fatores como responsabilidade, autoridade e melhor aplicação. São apresentados cinco tipos de EGP, brevemente comentados abaixo:

\section{Center of Excellence}

O objetivo primário é desenvolver e manter os padrões e metodologias de gerenciamento de projetos e promover sua divulgação e utilização por toda organização. O Center of Excellence não tem autoridade e não toma decisões sobre os projetos. São utilizados como suporte aos gerentes de projetos, atuando como uma consultoria e sua autoridade vêm justamente pela capacidade técnica em gestão de projetos de sua equipe. Atuam também como agentes de mudança, oferecendo conselhos para profissionais de todos os níveis da organização.

\section{Project Support Office (PSO)}

Além de desenvolver, manter e promover a utilização dos padrões e metodologias de gerenciamento de projetos, o PSO também suporta ativamente os vários projetos da empresa, fornecendo serviços como construção e atualização de planos de projetos, orçamentos e cronogramas. Os PSO são formados por analistas de planejamento, nos quais são responsáveis por manter atualizadas as informações dos projetos, porém não assumem a responsabilidade perante o empreendimento. Estes analistas frequentemente tornam-se gerentes de projetos, o que seria também uma contribuição do PSO.

\section{Project Management Office (PMO)}

Além de ter as mesmas obrigações do PSO, como fornecer suporte para elaboração e atualização de cronogramas e orçamentos, o PMO também é responsável por fornecer os gerentes de projetos para os projetos de toda organização. Dessa forma o PMO torna-se o equivalente à "casa" dos gerentes de projetos, responsabilizando-se pelo crescimento na carreira, por seus salários e pela formação e qualidade técnica de seu quadro de 
profissionais. Ainda assim, o PMO é responsável apenas for fornecer os gerentes de projetos, não sendo responsável pelo sucesso ou falha do empreendimento. A responsabilidade pelo empreendimento continua sendo do responsável da área onde o gerente de projetos foi alocado.

\section{Program Management Office (PrgMO)}

O objetivo principal do PrgMO é fornecer conhecimento em gerenciamento de projetos para todo programa, trabalhando na união de todos os projetos. Um PrgMO possui equipes que executam várias funções de gestão de projetos, tais como orçamentos, cronogramas e gerenciamento de riscos. Como o PSO, o PrgMO não é o responsável pela execução do projeto, sendo este um papel da gerência onde o gerente de projetos está alocado. Sua tarefa básica é fornecer as boas práticas de gestão de projetos e suportá-las. Porém, diferente do PSO, o PrgMO participa das decisões do programa, tendo uma participação na decisão equivalente aos gerentes dos projetos. E, diferente de todos os outros tipos de EGP citados, o PrgMO é desmobilizado após a conclusão do programa.

\section{Accountable Project Office (APO)}

Além de ter as mesmas obrigações do PMO, o Accountable Project Office é também o total responsável pelos objetivos, qualidade, custos e cronogramas dos projetos a ele designados. Como o PMO, torna-se também o equivalente à "casa" para os gerentes de projetos e a equipe de gerenciamento, responsabilizando-se pelas suas carreiras.

A Tabela 4 resume os tipos de EGP e suas responsabilidades conforme apresentados por Verzuh (2005).

Verzuh (2005) também afirma que os modelos de EGP não podem ser considerados como evolutivos. Pois isto iria sugerir que o Center of Excellence seria apenas o começo de uma evolução e que se devesse chegar ao Accountable Project Office. Ao invés disso, o modelo de EGP deve refletir a estrutura organizacional da empresa e como os projetos estão alocados dentro dela. 


\begin{tabular}{|c|c|c|c|c|c|}
\hline \multirow{2}{*}{ Tipos de EGP por suas Responsabilidades } & \multicolumn{5}{|c|}{ Autoridade para influir nos projetos } \\
\hline & Baixa & & $<-->$ & & Alta \\
\hline Responsabilidade & 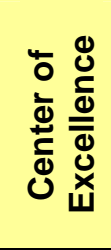 & 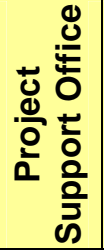 & 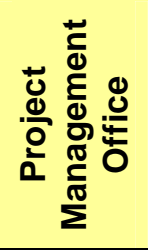 & 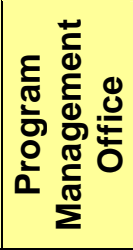 & 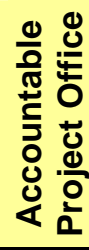 \\
\hline Manutenção de padrões & $\mathbf{R}$ & $\mathbf{R}$ & $\mathbf{R}$ & $\mathbf{R}$ & $\mathbf{R}$ \\
\hline Manutenção dos históricos dos projetos & $\mathbf{R}$ & $\mathbf{R}$ & $\mathbf{R}$ & $\mathbf{R}$ & $\mathbf{R}$ \\
\hline Organização de treinamentos & $\mathbf{P}$ & $\mathbf{P}$ & $\mathbf{P}$ & $\mathbf{P}$ & $\mathbf{P}$ \\
\hline Mentoring ${ }^{6}$ e Consultoria & $\mathbf{P}$ & $\mathbf{R}$ & $\mathbf{R}$ & $\mathbf{R}$ & $\mathbf{R}$ \\
\hline Análises de cronogramas e orçamentos & & $\mathbf{R}$ & $\mathbf{R}$ & $\mathbf{R}$ & $\mathbf{R}$ \\
\hline Preparação de informações de projetos & & $\mathbf{R}$ & $\mathbf{R}$ & $\mathbf{R}$ & $\mathbf{R}$ \\
\hline Coordenação de múltiplos projetos & & $\mathbf{P}$ & $\mathbf{P}$ & $\mathbf{R}$ & $\mathbf{R}$ \\
\hline Tomada de decisões em gerenciamento de projetos & & & & $\mathbf{R}$ & $\mathbf{R}$ \\
\hline Supervisão de gerentes de projetos & & & $\mathbf{P}$ & & $\mathbf{R}$ \\
\hline Cumprimento de objetivos de projetos & & & $\mathbf{P}$ & $\mathbf{P}$ & $\mathbf{R}$ \\
\hline Crescimento na carreira para gerentes de projetos & $\mathbf{P}$ & $\mathbf{P}$ & $\mathbf{R}$ & $\mathbf{P}$ & $\mathbf{R}$ \\
\hline Fornecimento de gerentes de projetos para a organização & & & $\mathbf{P}$ & & $\mathbf{R}$ \\
\hline Participação no gerenciamento do portfólio de projetos & $\mathbf{P}$ & $\mathbf{P}$ & $\mathbf{P}$ & $\mathbf{R}$ & $\mathbf{R}$ \\
\hline
\end{tabular}

Tabela 4: Tipos de EGP por suas Responsabilidades

(Fonte: adaptado de Verzuh, 2005)

\section{b) Modelo de Dinsmore (1998)}

O modelo de Dinsmore (1998) considera o EGP como a "casa do gerenciamento de projetos". Ele considera cinco modelos:

\section{Authonomous Project Team (APT)}

Em algumas situações nas quais as empresas realizam alguns projetos autônomos, as funções do gerenciamento de projetos permanecem dentro do próprio projeto. Nestes casos, as experiências sobre práticas de gestão de projetos vêm dos líderes das próprias equipes do projeto, e a organização não fornece suporte algum. Todos os custos da equipe são alocados no próprio projeto. A função deste tipo de EGP é gerenciar e executar todas as tarefas

\footnotetext{
${ }^{6}$ Mentoring ou Aconselhamento: atividade na qual um profissional oferece serviço de apoio a outro, no intuito de instruí-lo na realização de uma atividade ou ação.
} 
do projeto, sendo responsável por todo sucesso ou fracasso do empreendimento. Eles são utilizados para projetos que não possuem interface com a organização e a empresa tem pouco conhecimento a oferecer.

\section{Project Management Center of Excellence (PMCOE)}

O PMCOE é o ponto focal da experiência em gerenciamento de projetos na empresa, mas não assume a responsabilidade pela sua execução e resultados. Seus custos são alocados como uma despesa geral de overhead, não sendo alocados diretamente nos projetos. A tarefa do PMCOE é em grande parte de natureza missionária: disseminar a idéia, converter os incrédulos e transformar os adeptos em praticantes. É responsável pelas metodologias em gerenciamento de projetos e também padronização de processos, treinamentos, consultoria interna, padronização de ferramentas e benchmarking. Ele deve também manter os canais de informação abertos entre os projetos e a comunidade externa ao gerenciamento de projetos. Para que funcione corretamente, necessita de: patrocínio da alta administração; liderança ativa, pois seu trabalho é de convencimento e não de uso da força; mostrar os benefícios do que está implantando; promover o desenvolvimento profissional; conhecimento no estado da arte. O PMCOE é útil para corporações com grandes responsabilidades e empreendimentos das mais diferentes naturezas e organizações que preferem uma atuação mais calma para influenciar a cultura interna.

\section{Project Support Office (PSO)}

O PSO fornece suporte técnico e administrativo, ferramentas e serviços de planejamento e controle para os vários gerentes de projetos da organização. Estes serviços incluem elaboração e atualização de cronogramas, orçamentos, gestão de contratos, ferramentas, métricas de projetos, gestão da documentação, gestão dos recursos, auditorias e controle das mudanças de escopo. Os recursos e custos envolvidos são alocados nos projetos. A responsabilidade pelo sucesso do projeto não reside no $\mathrm{PSO}$, e sim nos gerentes de projetos que utilizam seus serviços. O PSO é mais comumente aplicado onde projetos são liderados por fortes gerentes de projetos, onde existe a consciência em gerenciamento de projetos dentro da organização, 
onde há necessidade de forte controle e formalização da documentação e onde há muitos projetos realizados simultaneamente.

\section{Program Management Office (PrgMO)}

O PrgMO gerencia os gerentes de projetos e é, em última instância, responsável pelos resultados dos projetos. Normalmente, concentra seus esforços em projetos prioritários. Outros projetos são gerenciados por departamentos ou áreas e recebem o suporte do PrgMO conforme necessário. O PrgMO compreende as funções do PMCOE e em alguns casos, as do PSO. É responsável pela alocação e gestão de recursos, recrutamento e desenvolvimento dos gerentes de projetos, gestão do portfólio, processos e metodologias de gestão de projetos e a coordenação dos gerentes de projetos. Para que um PrgMO funcione adequadamente, é necessário: poder, prioridade corporativa e controle em âmbito empresarial. Os PrgMO são normalmente aplicados quando a corporação está convencida em gerenciar negócios prioritários como projetos, quando há uma adequada maturidade organizacional para trabalhar com projetos e quando não gerenciar os negócios por projetos irá trazer graves conseqüências negativas.

\section{Chief Project Office (CPO)}

O CPO é responsável por criar e cuidar do gerenciamento de portfólio de projetos da organização, desde o estágio de decisão do negócio até sua implementação final. As atividades do CPO são: envolvimento nas decisões de negócios que resultem em novos projetos; planejamento estratégico de projetos; estabelecer prioridades e negociar recursos dos projetos; supervisão da implantação dos projetos estratégicos; responsável pelo sistema de

gerenciamento de projetos em nível empresarial; desenvolver a conscientização e a capacidade em gerenciamento de projetos através da organização; avaliação periódica dos projetos, incluindo a decisão pela sua descontinuidade; e o gerenciamento de stakeholders de alto nível, facilitação e aconselhamento (mentoring). O CPO faz sentido para organizações globais, orientada a projetos, multidisciplinares e que requerem prazos exíguos para entrega de múltiplos e complexos projetos. 
A Tabela 5 mostra uma comparação entre os cinco modelos propostos por Dinsmore (1998).

Segundo Dinsmore (1998), estes cinco modelos são soluções puras e que normalmente são aplicadas fazendo-se uma combinação entre elas. Ele reforça também que estes modelos não são evolutivos, sendo que cada um deles atende a uma necessidade específica.

\begin{tabular}{|c|c|c|c|c|c|}
\hline Funções & APT & PSO & PMCOE & PrgMO & CPO \\
\hline $\begin{array}{l}\text { Prazo, Escopo, Custo Qualidade, } \\
\text { Riscos, Suprimentos, } \\
\text { Comunicações, RH, Integração }\end{array}$ & executa & suporta & educa & supervisiona & $\begin{array}{l}\text { responsável } \\
\text { final }\end{array}$ \\
\hline $\begin{array}{l}\text { Responsabilidade por múltiplos } \\
\text { projetos }\end{array}$ & & suporta & articula & coordena & \\
\hline $\begin{array}{l}\text { Consistência do gerenciamento de } \\
\text { projetos em toda a organização }\end{array}$ & & suporta & articula & & $\begin{array}{l}\text { responsável } \\
\text { final }\end{array}$ \\
\hline $\begin{array}{l}\text { Desenvolvimento da competência } \\
\text { em gerenciamento de projetos }\end{array}$ & & & promove & coordena & $\begin{array}{l}\text { responsável } \\
\text { final }\end{array}$ \\
\hline $\begin{array}{l}\text { Alinhamento das estratégias de } \\
\text { negócios com os projetos }\end{array}$ & & & & & articula \\
\hline $\begin{array}{l}\text { Acompanhamento dos projetos em } \\
\text { âmbito empresarial }\end{array}$ & & & & & executa \\
\hline
\end{tabular}

Tabela 5: Funções de Gerenciamento de Projetos por tipos de EGP (fonte: adaptado de Dinsmore, 1998)

\section{d) Modelo de Casey e Peck (2001)}

Casey e Peck (2001) parte do pressuposto de que não existe um único tipo de EGP que atenda a todas as necessidades, pois cada modelo resolve diferentes problemas dentro da organização. Eles propõem três tipos de EGP que podem ser aplicados individualmente ou combinados entre eles:

\section{Estação Metereológica (Weather Station)}

É utilizado para monitorar, controlar e divulgar o status dos projetos da empresa. Ele é responsável por buscar, formatar e divulgar as informações dos projetos dentro da organização, tais como a situação física e financeira dos projetos, os maiores riscos e a satisfação dos clientes. Este EGP não tem 
autoridade sobre os projetos, sendo apenas um facilitador na coleta e divulgação de informações. Portanto, não tem força para resolver os grandes problemas de gestão de projetos da organização.

\section{Torre de Controle (Control Tower)}

É responsável pela construção, implantação e manutenção das metodologias em gerenciamento de projetos na empresa, com funções como: estabelecer padrões, treinamentos, garantir a utilização das metodologias e seu aprimoramento contínuo. Este EGP também não tem autoridade nem responsabilidade sobre os projetos, fazendo um papel de fomentador e desenvolvedor das melhores práticas. As funções da Torre de Controle podem e devem ser combinadas com a da Estação Metereológica para um melhor desempenho.

\section{Pool de Recursos (Resource Pool)}

Tem a responsabilidade de selecionar e fornecer gerentes de projetos aos projetos da empresa, de forma que sejam todos capacitados e alinhados com as metodologias de gestão de projetos da organização. Ainda assim o EGP não tem a responsabilidade perante o projeto e sim, responsabilidade sobre a qualidade do trabalho realizado pelos gerentes de projetos, podendo inclusive trocá-los se achar conveniente. Dessa forma é um EGP com razoável força dentro da empresa. Este Pool de Recursos é aconselhável que seja combinado com os outros dois tipos de EGP (Estação Metereológica e Torre de Controle).

Casey e Peck (2001) relembram que o tipo de EGP indicado para a empresa dependerá das necessidades que ela está vivenciando. E que, provavelmente, uma combinação entre os tipos propostos seja o mais adequado. Para exemplificar uma utilização de seus modelos, os autores geraram um exemplo conforme apresentado na Figura 8 onde, para projetos que percorrem vários departamentos, poder-se-iam utilizar os três tipos de EGP. Para grandes projetos gerenciados por uma única área, seria interessante ter dois tipos (Estação Metereológica e Torre de Controle). Para médios projetos, em uma única área, poder-se-ia utilizar o EGP tipo Estação Metereológica. 


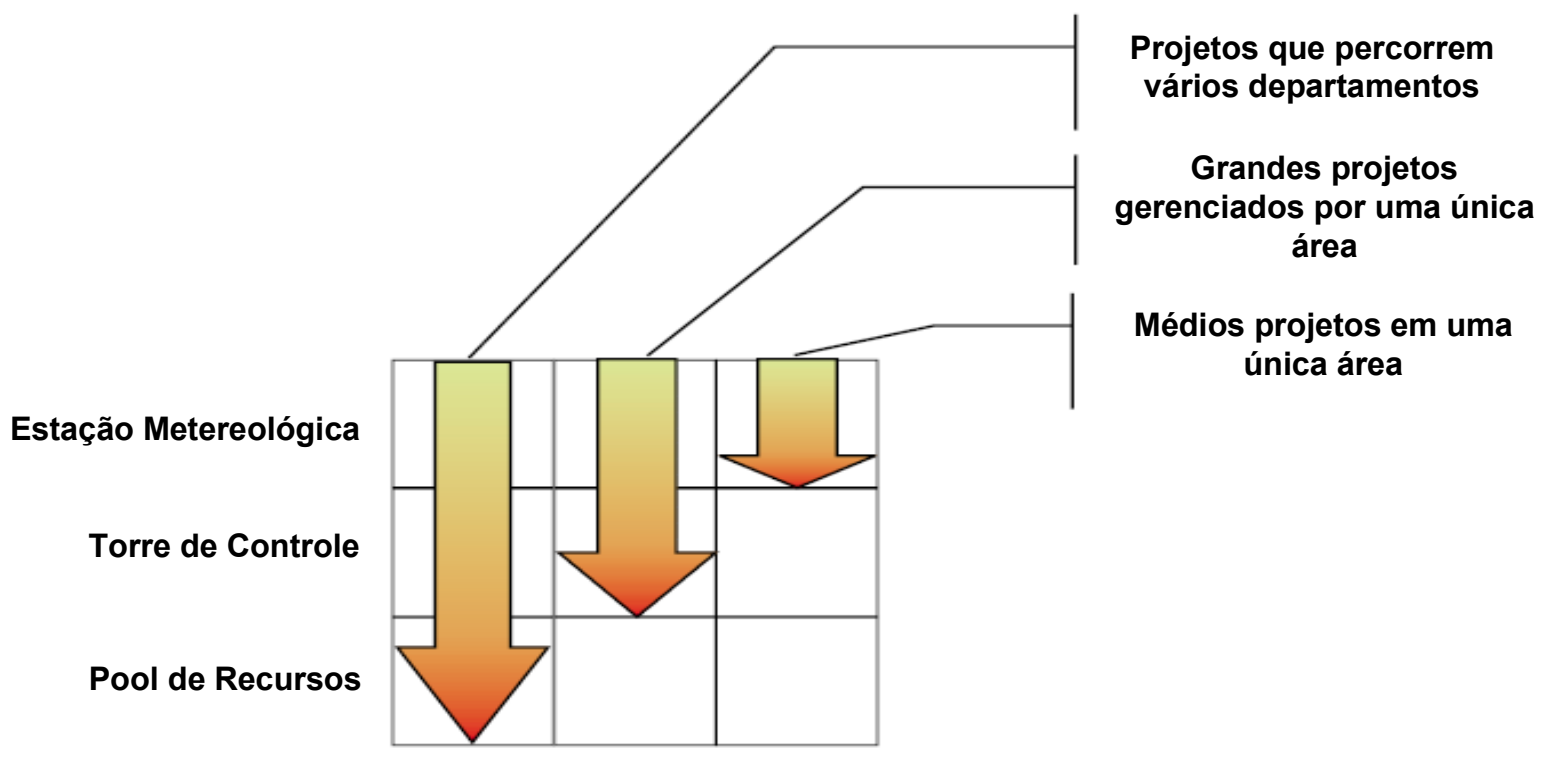

Figura 8: Exemplo de aplicação dos Modelos de EGP de Casey e Peck.

(Fonte: Casey e Peck, 2001)

\section{e) Análise dos Modelos}

Pela análise dos modelos de EGP apresentados, nota-se que realmente a diferenciação entre um modelo e outro ocorre na definição de quais funções e qual a autoridade é designada a cada modelo.

Com isso, uma conclusão que se obtém é que se for eliminado dos modelos de EGP os fatores relacionados à "autoridade", pode-se observar que os modelos se tornam basicamente um agrupamento de funções.

Um problema apontado por Hobbs e Aubry (2007) está na aplicação dessas tipologias na vida real. O cenário real das empresas onde esses EGP podem ser aplicados é muito mais complexo do que o apontado pelas tipologias e variam enormemente em vários aspectos de uma empresa para outra. Hobbs e Aubry (2007) acreditam que a redução de todos os inúmeros cenários possíveis a três, quatro ou cinco modelos é uma redução radical, e dependendo de como for utilizado, poderá gerar prejuízo na qualidade da informação. 
Portanto, a abordagem de adoção de um modelo para aplicação em uma empresa não é a mais recomendável sob o ponto de vista de um usuário que está na fase de planejar o seu EGP e precisa decidir sobre como irá implantá-lo na sua organização. Conforme afirmado por Casey e Peck (2001), nenhum modelo de EGP se encaixa perfeitamente em uma empresa.

Como conclusão da análise crítica sobre os tipos de EGP, propõe-se o seguinte:

> Para o planejamento de um EGP a ser implantado em uma empresa, deve-se discutir os aspectos relacionados às funções (responsabilidades) e ao poder (autoridade) do EGP;

> Para os aspectos relacionados às funções, devem-se determinar quais são as funções que irão atender as necessidades da empresa, visando resolver os problemas identificados no planejamento estratégico;

Os aspectos referentes à autoridade devem estar relacionados às funções e aos objetivos designados ao EGP no planejamento estratégico, de tal forma que seja dada ao EGP o poder necessário para realizar as suas atividades. A definição dessa autoridade está relacionada com a definição do posicionamento do EGP na estrutura organizacional e com a cultura organizacional da empresa;

Dessa forma, a conclusão obtida é que se torna desnecessária a definição do tipo de EGP a ser aplicado na empresa, pois o assunto teria sido contemplado pela determinação das funções e da autoridade.

No item seguinte são apresentadas as funções que um EGP pode desempenhar numa organização.

\subsubsection{Funções}

As funções a serem designadas a um Escritório de Gerenciamento de Projetos devem estar relacionadas aos problemas existentes na gestão de projetos, programas e portfólios, cuja responsabilidade pela solução a organização pretende 
transferir ao EGP. Uma listagem destes problemas mais comuns é mostrada no item 3.3.1 dessa dissertação.

Dessa forma, existe uma infinidade de funções que podem ser designadas a um EGP. Cada empresa tem problemas e necessidades específicas e cada uma delas pode atribuir de maneira particular a responsabilidade pela solução desses problemas ao seu EGP.

Hobbs e Aubry (2007), através de estudo de caso e revisão da literatura, identificaram as 27 funções mais comumente atribuídas ao EGP. Para estas, foi realizada uma pesquisa no qual mostra o percentual onde essas funções aparecem de forma relevante para a empresa. O resultado desta pesquisa é mostrado na Tabela 6.

\begin{tabular}{|c|c|}
\hline Função do EGP & $\%$ de EGP \\
\hline Reportar status dos projetos para gerência superior & $83 \%$ \\
\hline Desenvolver e implementar uma metodologia padronizada & $76 \%$ \\
\hline Monitorar e controlar o desempenho dos projetos & $65 \%$ \\
\hline Desenvolver a competência das pessoas, incluindo treinamento & $65 \%$ \\
\hline Implementar e operar um sistema de gerenciamento de projetos & $60 \%$ \\
\hline Prover conselhos para gerência superior & $60 \%$ \\
\hline Coordenação entre projetos & $59 \%$ \\
\hline Desenvolver e manter um painel de controle dos projetos & $58 \%$ \\
\hline Promover a gestão de projetos dentro da organização & $55 \%$ \\
\hline Monitorar e controlar o desempenho do EGP & $50 \%$ \\
\hline Participar do planejamento estratégico & $49 \%$ \\
\hline Prover aconselhamento aos gerentes de projetos & $49 \%$ \\
\hline Gerenciar um ou mais portfólios & $49 \%$ \\
\hline Identificar, selecionar e priorizar novos projetos & $48 \%$ \\
\hline Gerenciar os arquivos da documentação dos projetos & $48 \%$ \\
\hline Gerenciar um ou mais programas & $48 \%$ \\
\hline
\end{tabular}

Tabela 6: Funções de EGP em ordem decrescente de importância (continua)

(Fonte: Traduzido de Hobbs e Aubry, 2007) 
Função do EGP

\begin{tabular}{|l|l|}
\hline Conduzir auditorias nos projetos & $45 \%$ \\
\hline Gerenciar as interfaces com cliente & $45 \%$ \\
\hline Prover um conjunto de ferramentas sem o esforço de padronizá-las & $42 \%$ \\
\hline Executar tarefas especializadas para os gerentes de projetos & $42 \%$ \\
\hline Alocar recursos entre os projetos & $40 \%$ \\
\hline Conduzir revisões pós projeto & $38 \%$ \\
\hline Implementar e gerenciar a base das lições aprendidas & $34 \%$ \\
\hline Implementar e gerenciar a base dos riscos & $29 \%$ \\
\hline Gerenciamento dos benefícios & $28 \%$ \\
\hline Benchmarking & $25 \%$ \\
\hline $\begin{array}{l}\text { Recrutar, selecionar, avaliar e determinar salários para os gerentes de } \\
\text { projetos }\end{array}$ & $22 \%$ \\
\hline
\end{tabular}

Tabela 6: Funções de EGP em ordem decrescente de importância (continuação) (Fonte: Traduzido de Hobbs e Aubry, 2007)

No intuito de complementar a lista de funções apresentada na Tabela 6, apresentam-se abaixo outras funções obtidas da revisão da literatura (Tabela 7):

\section{Função do EGP}

\section{Referência}

\begin{tabular}{|l|l|}
\hline Gerenciar um ou mais projetos & $\begin{array}{l}\text { Verzuh (2005); Kerzner } \\
(2003)\end{array}$ \\
\hline Supervisionar e avaliar os gerentes de projetos & $\begin{array}{l}\text { Verzuh (2005); Kerzner } \\
(2003)\end{array}$ \\
\hline Fornecer gerentes de projetos para a organização & $\begin{array}{l}\text { Verzuh (2005); Kerzner } \\
(2003)\end{array}$ \\
\hline Atuar na resolução de conflitos & $\begin{array}{l}\text { Rad e Raghavan (2000); } \\
\text { Kerzner (2003) }\end{array}$ \\
\hline Definir as funções e responsabilidades dos gerentes de projetos & Kerzner (2003) \\
\hline Prover suporte aos gerentes e equipes de projetos & Block e Frame (1998) \\
\hline Prover consultoria em gerenciamento de projetos & Block e Frame (1998) \\
\hline
\end{tabular}

Tabela 7: Mais Funções de EGP

(Fonte: autor)

Uma forma útil e didática de analisar e organizar as funções existentes é agrupando as funções que estão logicamente relacionadas. A seguir, apresentam-se algumas formas de se fazer este agrupamento: 


\section{a) Agrupamento proposto por Rad e Raghavan (2000)}

Rad e Raghavan agrupam as funções em dois grupos: as ligadas aos Processos e as ligadas às Pessoas.

As funções relativas aos Processos cobrem as atividades de planejar e executar os processos e procedimentos necessários para assegurar a correta implementação dos métodos da gestão de projetos. Entre as atividades desta categoria, destacamse:

> Suporte administrativo aos projetos;

> Consultoria e aconselhamento (mentoring);

$>$ Elaboração de padrões e procedimentos.

Já as funções relativas às Pessoas cobrem as atividades para selecionar, manter e gerenciar as pessoas envolvidas no ambiente de projetos. Entre as atividades desta categoria, destacam-se:

> Prover gerentes de projetos para a organização;

$>$ Identificar as habilidades requeridas nos projetos;

> Recrutar, desenvolver e manter os gerentes de projetos;

> Treinar em práticas de gerenciamento de projetos;

$>$ Atuar na resolução de conflitos.

Para Rad e Raghavan (2000) é o correto balanceamento entre estes dois grupos de funções que garante o sucesso do EGP. De maneira contrária, uma ênfase maior em um dos grupos de funções poderia trazer sérias conseqüências ao EGP.

\section{b) Agrupamento proposto por Hobbs e Aubry (2007)}

Estes autores apresentam 5 grupos de funções e mais 3 funções separadas. Este agrupamento é baseado nas funções apresentadas na Tabela 6 .

> Grupo 1: Monitoramento e Controle do Desempenho do Projeto

- Reportar status dos projetos para gerência superior; 
- Monitorar e controlar o desempenho dos projetos;

- Implementar e operar um sistema de gerenciamento de projetos;

- Desenvolver e manter um painel de controle dos projetos.

> Grupo 2: Desenvolvimento das Competências e Metodologias em Gerenciamento de Projetos

- Desenvolver e implementar uma metodologia padronizada;

- Desenvolver a competência das pessoas, incluindo treinamento;

- Promover a gestão de projetos dentro da organização;

- Prover aconselhamento aos gerentes de projetos;

- Prover um conjunto de ferramentas sem o esforço de padronizá-las.

Grupo 3: Gerenciamento de Múltiplos Projetos

- Coordenar as interferências entre projetos;

- Gerenciar um ou mais portfólios;

- Identificar, selecionar e priorizar novos projetos;

- Gerenciar um ou mais programas;

- Alocar recursos entre os projetos.

Grupo 4: Gerenciamento Estratégico

- Prover conselhos para gerência superior;

- Participar do planejamento estratégico;

- Gerenciamento dos benefícios;

- Benchmarking.

Grupo 5: Aprendizado Organizacional

- Monitorar e controlar o desempenho do EGP;

- Gerenciar os arquivos da documentação dos projetos;

- Conduzir auditorias nos projetos;

- Conduzir revisões pós projeto;

- Implementar e gerenciar a base das lições aprendidas;

- Implementar e gerenciar a base dos riscos. 
Funções separadas:

- Executar tarefas especializadas para os gerentes de projetos (ex.: preparar cronogramas);

- Gerenciar as interfaces com cliente;

- Recrutar, selecionar, avaliar e determinar salários para os gerentes de projetos.

\section{c) Agrupamento proposto pelo autor desta dissertação}

Os agrupamentos propostos por Rad e Raghavan e Hobbs e Aubry são bastante úteis, mas não contemplam todas as funções identificadas nesta dissertação. No intuito de promover um agrupamento que inclua todas as funções identificadas, apresenta-se abaixo uma nova proposta de agrupamento. Nela são criados Grupos de Funções que agrupam as funções que possuem características semelhantes, conforme apresentado na Tabela 8.

\begin{tabular}{|c|c|c|}
\hline & Grupos de Funções & Objetivo \\
\hline 1 & $\begin{array}{l}\text { Gerenciamento } \\
\text { Estratégico }\end{array}$ & $\begin{array}{l}\text { Desenvolvimento de políticas de gestão de projetos para } \\
\text { toda organização e participação ativa nas estratégias } \\
\text { corporativas. }\end{array}$ \\
\hline 2 & $\begin{array}{l}\text { Gerenciamento de } \\
\text { Múltiplos Projetos }\end{array}$ & $\begin{array}{l}\text { Alinhamento dos projetos com os objetivos estratégicos da } \\
\text { organização. Gerenciamento, integração e controle dos } \\
\text { múltiplos projetos da organização, buscando otimização de } \\
\text { recursos. }\end{array}$ \\
\hline 3 & Gestão de Recursos & $\begin{array}{l}\text { Fornecimento de recursos de projetos para organização, } \\
\text { sendo a "casa" da equipe de gerenciamento. }\end{array}$ \\
\hline 4 & Gestão da Execução & $\begin{array}{l}\text { Gestão e integração do projeto, assumindo a } \\
\text { responsabilidade pela execução do projeto e pelo } \\
\text { atingimento da qualidade e objetivos estipulados. }\end{array}$ \\
\hline 5 & Planejamento & Execução de tarefas de planejamento. \\
\hline 6 & $\begin{array}{l}\text { Monitoramento e } \\
\text { Controle do Desempenho }\end{array}$ & $\begin{array}{l}\text { Monitoramento, controle e divulgação das informações de } \\
\text { evolução dos projetos a todos interessados. }\end{array}$ \\
\hline 7 & $\begin{array}{l}\text { Desenvolvimento das } \\
\text { Competências e } \\
\text { Metodologias }\end{array}$ & $\begin{array}{l}\text { Desenvolvimento das competências, implantação de } \\
\text { metodologias, treinamentos e promoção da gestão de } \\
\text { projetos e da mudança da cultura organizacional. }\end{array}$ \\
\hline
\end{tabular}

Tabela 8: Grupos de Funções (continua)

(Fonte: autor) 
Grupos de Funções

\begin{tabular}{|c|l|l|}
\hline 8 & Ferramentas & $\begin{array}{l}\text { Desenvolvimento e aplicação das ferramentas de gerenciamento } \\
\text { de projetos. }\end{array}$ \\
\hline 9 & $\begin{array}{l}\text { Aprendizado } \\
\text { Organizacional }\end{array}$ & $\begin{array}{l}\text { Promoção das práticas para melhoria contínua da gestão de } \\
\text { projetos, incluindo as lições aprendidas e o controle do } \\
\text { desempenho do próprio EGP. }\end{array}$ \\
\hline 10 & $\begin{array}{l}\text { Interface com } \\
\text { Clientes }\end{array}$ & $\begin{array}{l}\text { Gerenciamento da interface com os clientes, garantindo a entrega } \\
\text { dos serviços e a satisfação do cliente. }\end{array}$ \\
\hline
\end{tabular}

Tabela 8: Grupos de Funções (continuação)

(Fonte: autor)

Cada um desses Grupos de Funções é composto por uma série de funções nas quais o EGP estaria comprometido em atuar. Abaixo apresentam-se uma série de funções de cada grupo, lembrando que esta lista de funções não tem o intuito de abranger todas as possíveis funções existentes.

\section{Gerenciamento Estratégico}

$>$ Prover conselhos para gerência superior;

> Participar do planejamento estratégico;

> Participação ativa nas estratégias corporativas;

> Desenvolvimento da integração entre áreas e departamentos;

$>$ Gerenciamento dos benefícios;

$>$ Benchmarking.

\section{Gerenciamento de Múltiplos Projetos}

> Gestão de Portfólios;

$>$ Identificar, selecionar e priorizar projetos;

> Gestão de Programas;

$>$ Coordenação entre projetos;

> Garantia da aderência dos projetos aos objetivos dos negócios;

> Decisão sobre descontinuidades de projetos;

> Gerenciamento de stakeholders de alto nível;

> Gerenciamento da carteira orçamentária de projetos;

$>$ Controle dos riscos da carteira 


\section{Gestão dos Recursos}

> Alocar recursos entre os projetos;

> Fornecer profissionais de gerenciamento para a empresa;

$>$ Gerenciamento e otimização dos recursos;

> Estudos da capacidade de realização de projetos da empresa;

> Recrutar, selecionar, avaliar e determinar salários para a equipe de projetos.

\section{Gestão da Execução do Projeto}

$>$ Gestão e integração do projeto;

> Garantia da entrega e qualidade dos deliverables;

$>$ Resolução de problemas e conflitos;

$>$ Tomada de decisões do projeto dentro de critérios estabelecidos;

> Definição das funções e responsabilidades dentro do projeto;

> Garantir a comunicação clara e eficiente do projeto;

> Garantir sistema de informações eficiente do projeto;

$>$ Supervisão da equipe do projeto;

$>$ Elaboração do plano do projeto;

$>$ Responsável pelo planejamento e estratégia de implantação do projeto.

\section{Planejamento}

$>$ Suporte ao gerenciamento do projeto;

> Executar tarefas de planejamento ao time e gerente de projetos;

> Preparar documentação do cliente.

\section{Monitoramento e Controle do Desempenho do Projeto}

> Reportar status e evolução dos projetos para todos interessados;

$>\quad$ Monitorar e controlar o desempenho dos projetos;

$>\quad$ Desenvolver e manter um painel de controle dos projetos. 


\section{Desenvolvimento das Competências e Metodologias}

> Desenvolver e implementar uma metodologia padronizada;

> Desenvolver a competência das pessoas, incluindo treinamento;

> Identificação das competências e habilidades requeridas;

$>$ Prover aconselhamento (mentoring) aos gerentes de projetos;

> Consultoria e assistência nos projetos;

> Promover a gestão de projetos dentro da organização;

> Promover a mudança de cultura na organização;

$>$ Promover a cultura pelo foco no planejamento do projeto.

\section{Ferramentas}

> Implementar e operar um sistema integrado de gerenciamento de projetos;

> Prover um conjunto de ferramentas sem o esforço de padronizálas;

> Desenvolver, implantar e operar ferramentas customizadas de gerenciamento de projetos;

> Selecionar, implementar, assistir e manter ferramentas de gerenciamento de projetos.

\section{Aprendizado Organizacional}

> Monitorar e controlar o desempenho do EGP;

> Desenvolver a base de dados sobre os projetos;

$>$ Conduzir avaliação e auditorias nos projetos;

> Implementar e gerenciar a base das lições aprendidas;

> Implementar e gerenciar a base dos riscos;

$>$ Conduzir revisões pós projeto;

> Capturar, compartilhar e transferir conhecimentos;

> Avaliar a satisfação dos clientes;

$>$ Avaliar a maturidade em gerenciamento de projetos.

\section{Interface com Clientes}

> Gerenciar as interfaces com o cliente;

$>$ Elaborar propostas comerciais. 
Estes Grupos de Funções funcionam como uma amostra do universo de possíveis funções que um Escritório de Gerenciamento de Projetos pode assumir dentro de uma organização. Estas funções podem ser combinadas de forma livre, utilizando em uma mesma empresa, desde apenas um grupo, alguns grupos ou até mesmo todos os grupos.

Todas as funções e os grupos de funções descritos são importantes, e em um contexto particular, qualquer uma delas pode ser a mais importante para a organização. A definição de quais funções serão consideradas dependerá de qual tipo de problema ou situação a organização está vivenciando no momento e de quais funções está disposta a entregar ao EGP. As organizações devem usar o bom senso para decidir quais funções entregarão ao EGP.

O usuário do EGP deve levar em consideração também a característica apontada por Andersen, Henriksen e Aarseth (2006) de que o EGP se desenvolve em uma estrutura dinâmica no decorrer do tempo, ou seja, ele pode iniciar com determinadas funções e no futuro agregar outras funções, de acordo com a evolução da maturidade em gestão de projetos da empresa.

\subsubsection{A Influência da Estrutura Organizacional}

A estrutura organizacional da empresa constitui-se num dos fatores que influenciam a constituição de um EGP. A estrutura organizacional está presente em todas as empresas e de certa forma demonstra a estrutura de poder existente. Um projeto e mesmo o EGP serão sempre influenciados por esta distribuição de poder e a equipe do projeto deve estar ciente de como isto pode afetá-lo (PMI, 2004).

As estruturas organizacionais variam da estrutura funcional à estrutura projetizada, passando por estruturas matriciais intermediárias (PMI, 2004), conforme mostrado na Tabela 9. 


\begin{tabular}{|c|c|c|c|c|c|}
\hline \multirow{2}{*}{$\begin{array}{l}\text { Estrutura da } \\
\text { organlzaçäo } \\
\text { Características } \\
\text { do projeto }\end{array}$} & \multirow{2}{*}{ Funcional } & \multicolumn{3}{|c|}{ Matricial } & \multirow[b]{2}{*}{ Aor projeta } \\
\hline & & Fraca & Balanceada & Forte & \\
\hline $\begin{array}{l}\text { Autoriciade do } \\
\text { gerente de projetos }\end{array}$ & $\begin{array}{l}\text { Pouca ou } \\
\text { nenhuma }\end{array}$ & Limitada & $\begin{array}{l}\text { Baixa a } \\
\text { moderada }\end{array}$ & $\begin{array}{c}\text { Moderada } \\
\text { a alta }\end{array}$ & $\begin{array}{c}\text { Alta a } \\
\text { quase total }\end{array}$ \\
\hline $\begin{array}{l}\text { Disponibilidade } \\
\text { de recursos }\end{array}$ & $\begin{array}{l}\text { Pouca ou } \\
\text { nenhuma }\end{array}$ & Limitada & $\begin{array}{l}\text { Baixa a } \\
\text { moderada }\end{array}$ & $\begin{array}{c}\text { Moderada } \\
\text { a alta }\end{array}$ & $\begin{array}{c}\text { Alta a } \\
\text { quase total }\end{array}$ \\
\hline $\begin{array}{l}\text { Quem controla o } \\
\text { orçamento do projeto }\end{array}$ & $\begin{array}{l}\text { Gerente } \\
\text { funcional }\end{array}$ & $\begin{array}{l}\text { Gerente } \\
\text { funcional }\end{array}$ & Misto & $\begin{array}{c}\text { Gerente de } \\
\text { projetos }\end{array}$ & $\begin{array}{c}\text { Gerente } \\
\text { de projetos }\end{array}$ \\
\hline $\begin{array}{l}\text { Funçäo do gerente } \\
\text { de projetos }\end{array}$ & Tempo parcial & Tempo parcial & Tempo integral & Tempo integral & Tempo integral \\
\hline $\begin{array}{l}\text { Equipe administrativa } \\
\text { do gerenciamento } \\
\text { de projetos }\end{array}$ & Tempo parcial & Tempo parcial & Tempo parcial & Tempo integral & Tempo integral \\
\hline
\end{tabular}

Tabela 9: Características das Estruturas Organizacionais (Fonte: PMI, 2004)

Nos próximos itens são apresentadas as características de cada tipo de estrutura organizacional (funcional, matricial e projetizada) e é realizada uma análise crítica sobre a influência da escolha de cada uma delas no planejamento da implantação de um EGP. É também apresentada uma análise crítica sobre a influência do posicionamento do EGP dentro da estrutura organizacional para o correto desempenho de suas atribuições.

\subsubsection{Estrutura Funcional}

A Estrutura Funcional é uma hierarquia em que cada funcionário tem um superior bem definido; os funcionários são agrupados por especialidades (ex.: engenharia, marketing, produção) e são gerenciados por uma pessoa especializada dessa área. Os projetos também podem ser executados através de equipes estruturadas conforme uma estrutura funcional, mas o escopo do projeto geralmente está restrito ao limite da função (PMI, 2004). A Figura 9 mostra um exemplo de estrutura funcional. 


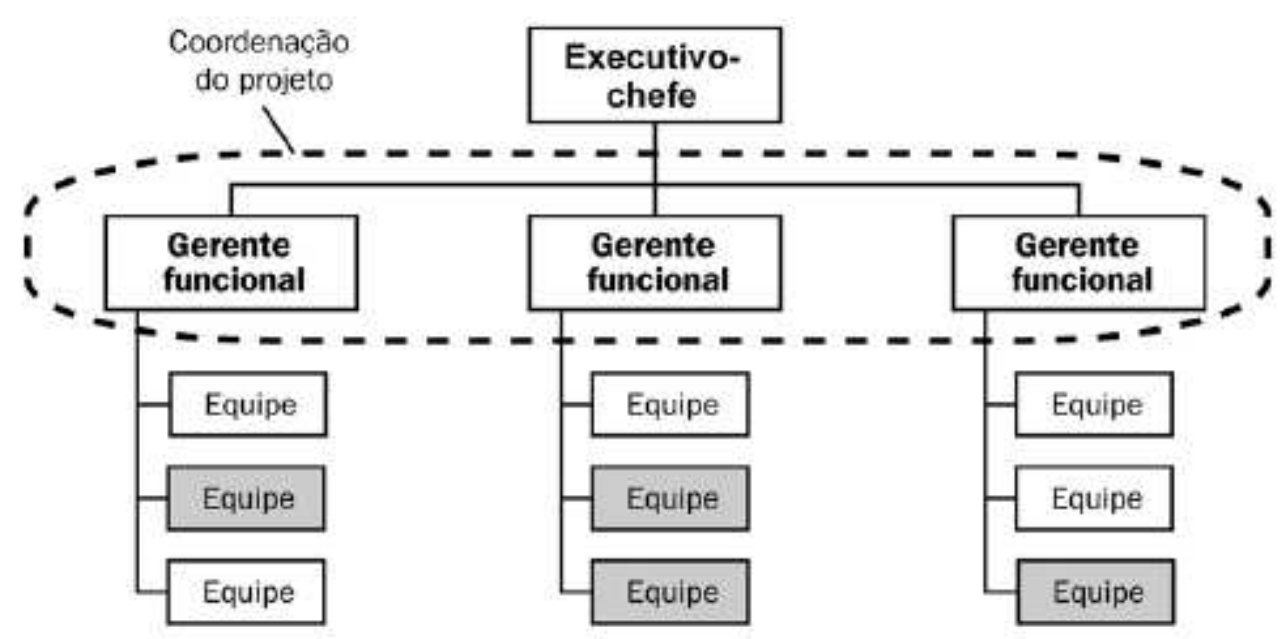

(As caixas cinzas representam equipes envolvidas em atividades do projeto.)

Figura 9: Estrutura Organizacional Funcional

(Fonte: PMI, 2004)

As vantagens e desvantagens deste tipo de estrutura organizacional são apresentadas por Patah (2004), extraídos de Meredith e Mantel (2000) e de Kerzner (2001a).

\section{Vantagens:}

$>$ Grande flexibilidade no uso dos recursos humanos;

> Especialistas podem ser utilizados em diferentes projetos;

> Facilidade de compartilhamento de conhecimentos entre especialistas da área funcional;

$>\mathrm{O}$ conhecimento tecnológico fica mantido no departamento quando da saída do profissional do projeto ou da empresa;

$>$ Possibilidade de evolução na carreira dentro da área funcional de forma mais natural;

$>$ Facilidade de controle do orçamento e custos do projeto;

> Possibilidade de um melhor controle técnico;

> Melhor controle hierárquico, pois cada funcionário possui somente um chefe;

$>$ Os canais de comunicação são verticais e bem estabelecidos.

\section{Desvantagens:}

$>$ O departamento funcional tende a ser orientado às suas atividades particulares; 
$>$ A responsabilidade total do projeto não é delegada a nenhum funcionário específico;

$>$ Existe uma tendência de subestimar o projeto;

> A estrutura funcional não facilita uma abordagem global do projeto;

> A coordenação torna-se complexa e é necessário um tempo de espera adicional para aprovação das decisões;

$>$ As decisões normalmente são tomadas em favor dos grupos funcionais mais fortes;

$>$ Não há foco nos clientes;

$>$ As respostas às necessidades dos clientes são lentas.

\subsubsection{Estrutura Projetizada}

A Estrutura Projetizada é uma hierarquia organizacional que possibilita que o gerente de projetos tenha autoridade total para atribuir prioridades, aplicar recursos e orientar o trabalho das pessoas designadas para o projeto. Nesta estrutura, os membros da equipe geralmente são colocados juntos (PMI, 2004). A Figura 10 mostra um exemplo de estrutura projetizada.

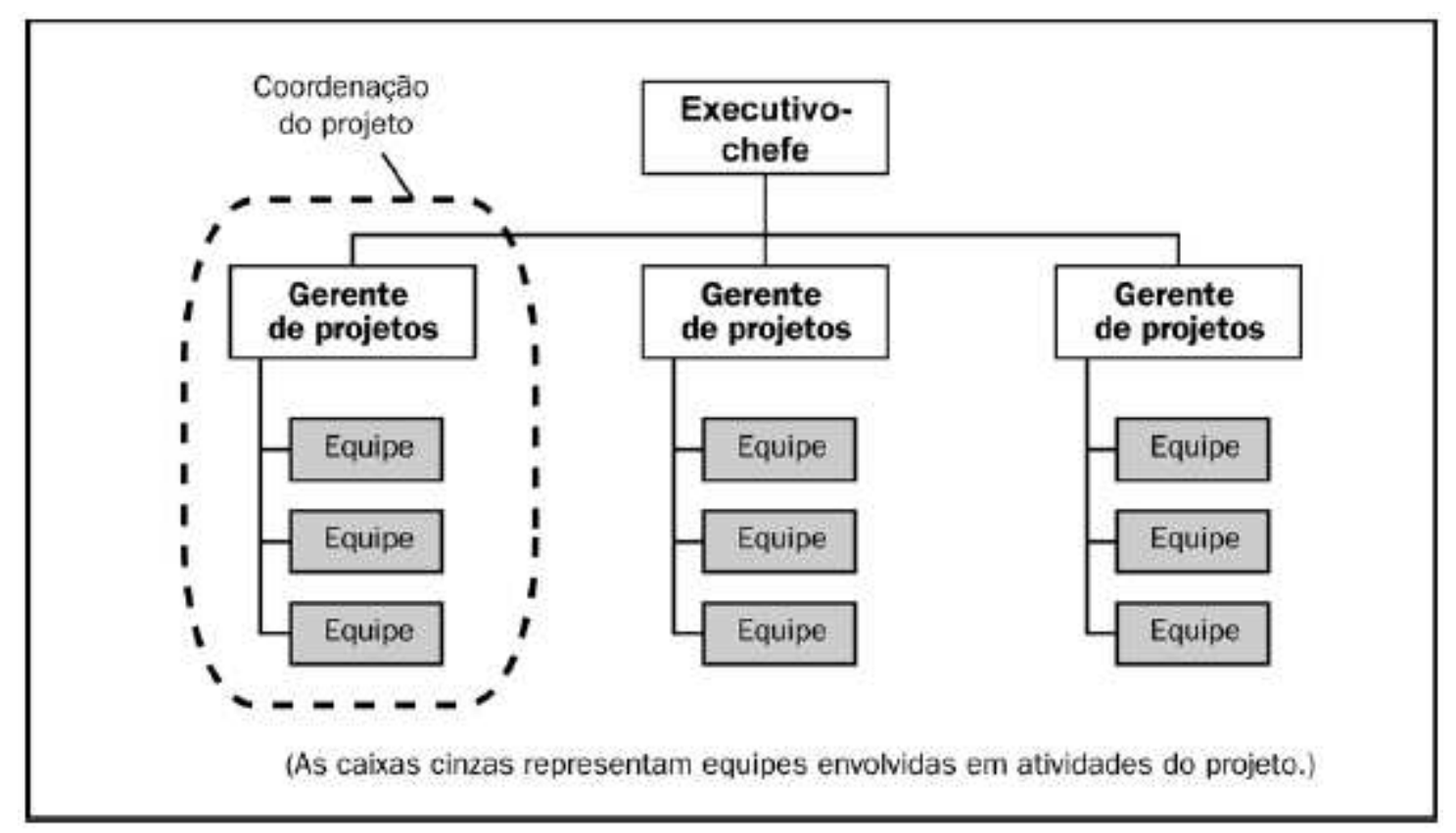

Figura 10: Estrutura Organizacional Projetizada

(Fonte: PMI, 2004) 
Segundo Kerzner (2001a), a maior vantagem da estrutura projetizada é que um único indivíduo, o gerente de projetos, mantém autoridade completa sobre o projeto como um todo. Patah (2004) apresenta outras vantagens e desvantagens, extraídas de Meredith e Mantel (2000) e de Kerzner (2001a).

\section{Vantagens:}

$>$ O gerente de projeto tem total autoridade sobre o projeto e sua equipe;

> As comunicações são facilitadas em comparação à estrutura funcional;

$>$ Tendência da equipe em desenvolver um alto nível de comprometimento e lealdade com o projeto;

> Possibilidade de maior rapidez nas tomadas de decisões;

> Estruturas projetizadas são estruturalmente simples e flexíveis, e relativamente fáceis de se compreender e implementar;

> A estrutura organizacional permite uma abordagem global do projeto;

> Possibilidade de manter as pessoas chaves dentro do departamento, sem a necessidade de compartilhá-las;

$>$ Rápida resposta aos clientes;

$>$ A interface com a alta administração torna-se mais fácil, uma vez que o tamanho da unidade é diminuído.

\section{Desvantagens:}

> Os especialistas tendem a serem alocados aos projetos quando eles estão disponíveis e não quando eles são necessários para o projeto;

> Estruturas projetizadas tendem a apresentar certa inconsistência na maneira pela quais as políticas e procedimentos internos da empresa são cumpridos;

> Existe uma considerável incerteza sobre o que irá ocorrer com os membros da equipe do projeto quando ele terminar;

> Possibilidade de duplicação de trabalhos, facilidades e pessoal quando a organização tem vários projetos. Os custos de manter esta estrutura podem ser proibitivos.

> Tendência de reter os funcionários em um projeto por um tempo maior que o necessário;

> Falta de oportunidades para o intercâmbio técnico entre os diferentes projetos;

$>$ Falta de continuidade de carreira para as pessoas que trabalham em projetos. 


\subsubsection{Estruturas Matriciais}

As características das organizações com estruturas matriciais são uma combinação de características das organizações funcionais com a das estruturas projetizadas. Nestas estruturas o gerente de projetos divide as responsabilidades com os gerentes funcionais para atribuição de prioridades e orientação do trabalho das pessoas designadas para o projeto (PMI, 2004).

O PMI (2004) apresenta as estruturas matriciais variando da fraca à forte, passando pela balanceada. As matrizes fracas mantêm muitas das características da funcional e a função do gerente de projetos é mais parecida com a de um coordenador ou facilitador; neste caso, os gerentes funcionais possuem mais poder que o gerente de projeto. As matrizes fortes já possuem as características parecidas às estruturas projetizadas e podem ter gerentes de projetos em tempo integral, com autoridade considerável e pessoal administrativo alocado em tempo integral; neste caso os gerentes de projetos possuem mais influência sobre a equipe do projeto do que os gerentes funcionais. As matrizes balanceadas encontram-se no meio do caminho; apesar de reconhecer a necessidade de um gerente de projetos, ela não fornece ao gerente de projetos autoridade total e recursos financeiros do projeto; neste caso os gerentes funcionais e os gerentes de projetos possuem a mesma influência sobre a equipe do projeto. As Figura 11, Figura 12 e Figura 13 mostram um exemplo dessas estruturas. 


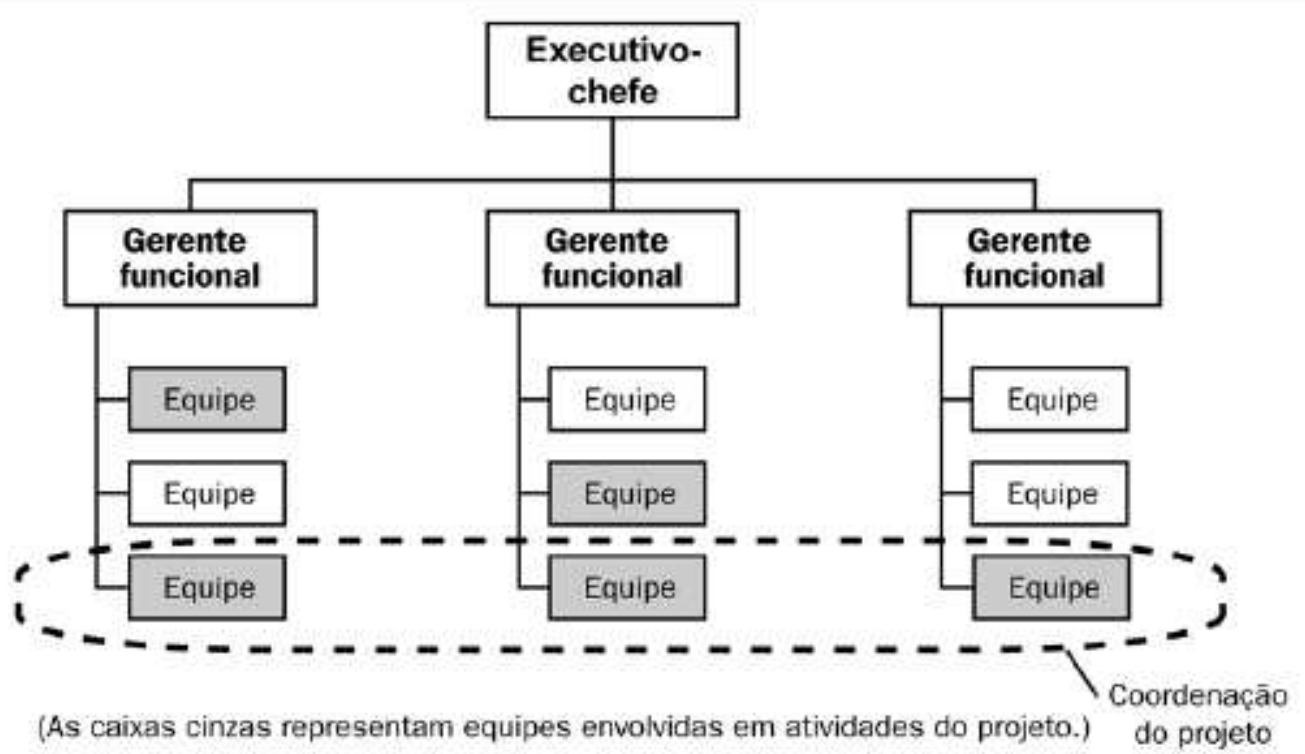

Figura 11: Estrutura Organizacional Matricial Fraca

(Fonte: PMI, 2004)

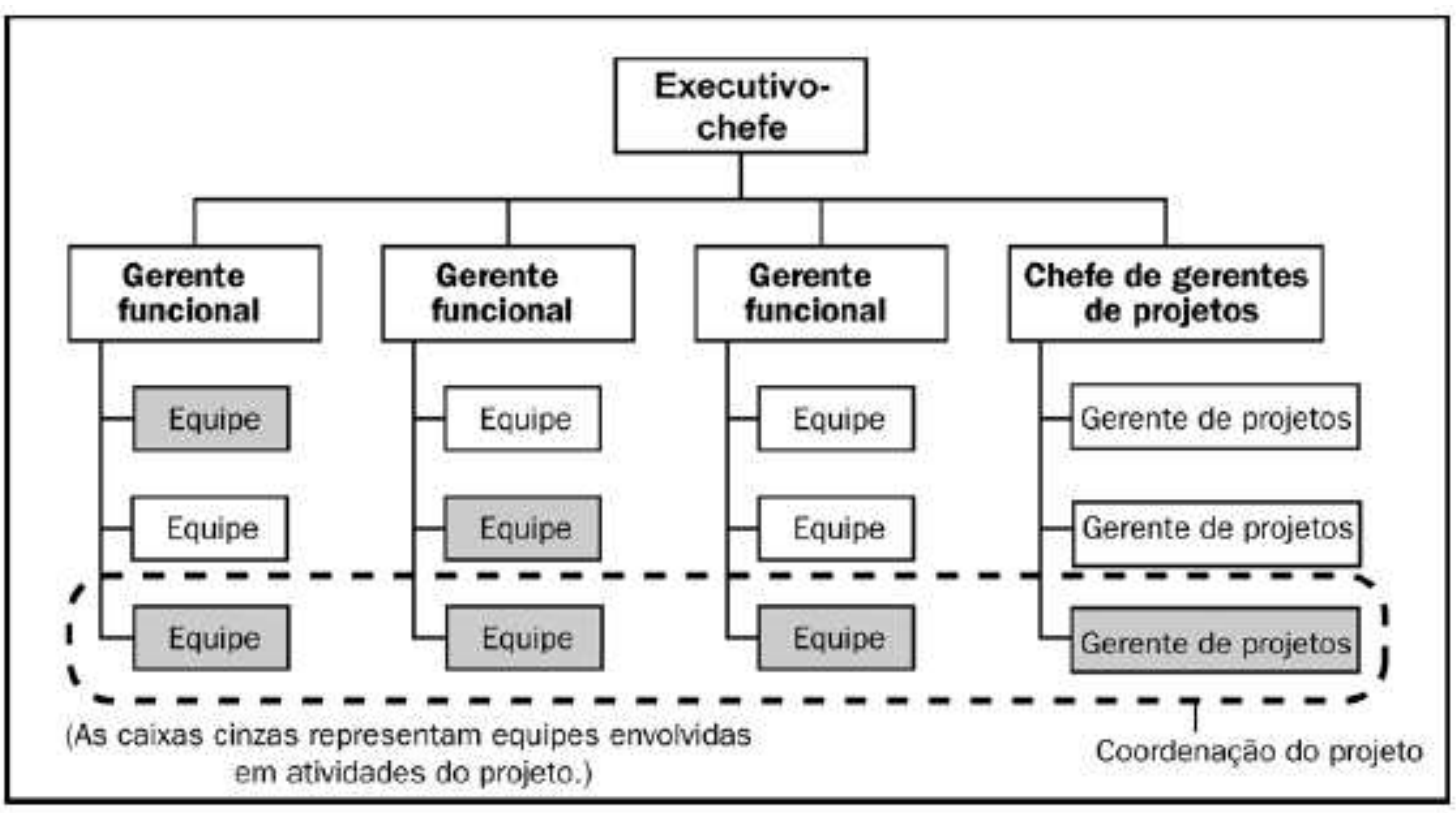

Figura 12: Estrutura Organizacional Matricial Forte

(Fonte: PMI, 2004) 


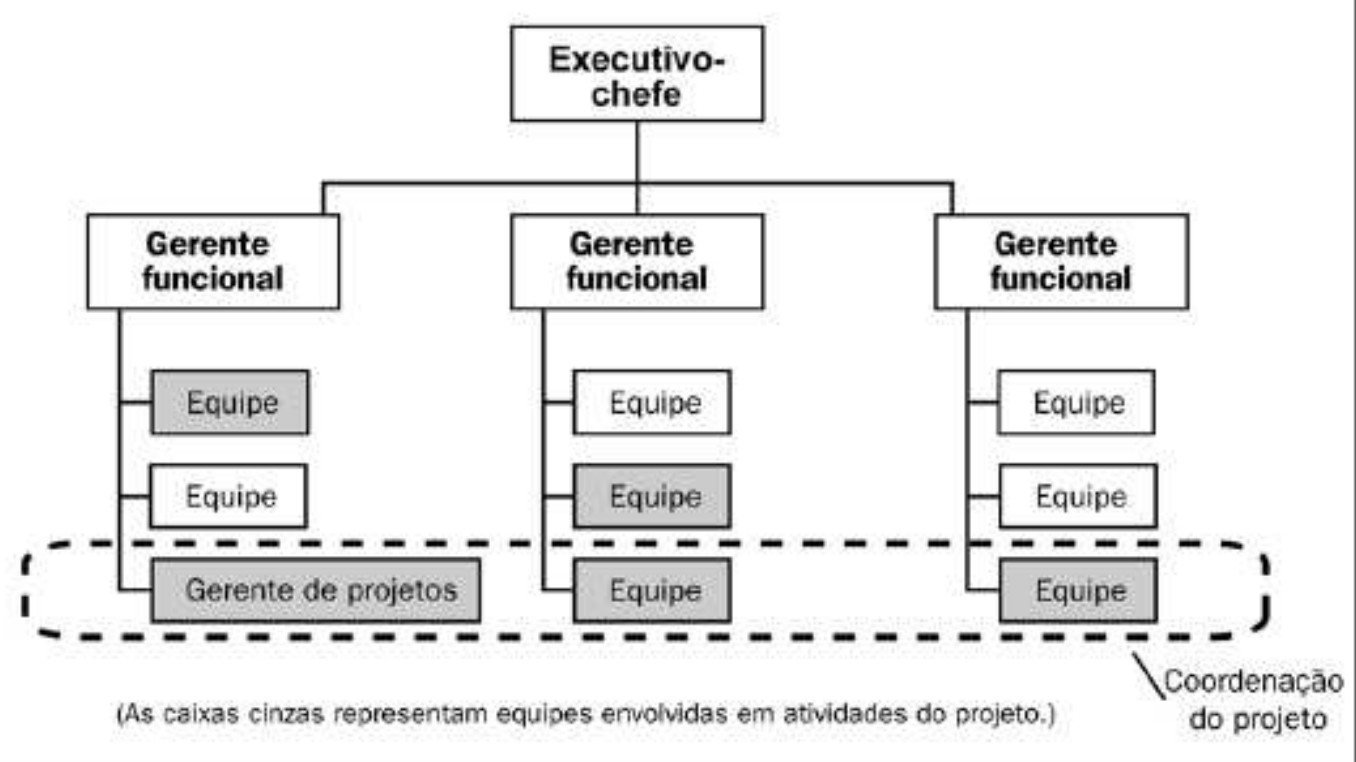

Figura 13: Estrutura Organizacional Matricial Balanceada (Fonte: PMI, 2004)

Patah (2004) apresenta algumas vantagens e desvantagens das estruturas matriciais, extraídas de Meredith e Mantel (2000) e de Kerzner (2001a).

\section{Vantagens:}

Utilização de toda a capacidade técnica da empresa, devido ao fato do projeto estar distribuído ao longo das divisões da empresa;

> Existe uma ansiedade menor sobre o que irá ocorrer com as pessoas com o fim do projeto; cada pessoa possui uma "casa" depois do encerramento do projeto;

$>$ A estrutura matricial é flexível;

> Maior otimização do uso de recursos da empresa, devido ao fato de normalmente ocorrerem vários projetos simultaneamente nas empresas; consequentemente, os custos são minimizados;

$>$ Ocorre um rápido desenvolvimento de especialistas e generalistas;

$>$ O stress é compartilhado por todo o time e pelos gerentes funcionais.

\section{Desvantagens:}

> Podem existir dúvidas quanto à responsabilidade pela tomada de uma decisão dentro do projeto; isto pode atrasar a realização do mesmo;

$>$ Os diferentes gerentes de projetos podem "competir" pelos recursos técnicos disponíveis na empresa, fazendo com que o uso dos mesmos deixe de ser realizado de maneira otimizada; 
$>$ É necessário que o gerente de projetos possua uma habilidade especial em negociar recursos com os gerentes funcionais;

$>$ A equipe do projeto tem que se reportar a dois chefes: o gerente de projetos e 0 gerente funcional;

> Existem fluxos de informação e trabalho multidimensionais;

$>$ Prioridades são alteradas continuamente;

> Os objetivos da gerência diferem dos objetivos do projeto;

> Existe um grande potencial para a ocorrência de conflitos;

$>$ Dificuldade de monitoração e controle.

\subsubsection{A Escolha da Estrutura Organizacional}

Verzuh (2005) apresenta alguns fatores que afetam a escolha da estrutura organizacional:

$>$ Projetos versus Operação - organizações que tem a maior parcela de sua receita oriunda de projetos são mais bem servidas numa estrutura projetizada;

> Amplitude de Funções - funções são usualmente organizadas em áreas de especialidades técnicas ou de conhecimento (engenharia, finanças, marketing). Se os projetos tendem a necessitar de múltiplas funções, os custos de comunicação e coordenação irão aumentar numa estrutura funcional. Se isto acontecer com freqüência, uma estrutura mais voltada a projetos será mais eficiente;

$>$ Tamanho - quanto maior o projeto e a receita oriunda de poucos deles, mais sentido fazem as estrutura projetizadas;

$>$ Duração do projeto - quanto mais longos os projetos, mais sentido faz organizar uma empresa ao redor de projetos;

$>$ Comprometimento do time - quanto maior a quantidade de pessoas alocadas em tempo integral a um projeto, mais forte é o indicador em favor das estruturas projetizadas;

$>$ Proporção de orçamento - quanto maior a receita proveniente de projetos, mas sentido faz a estrutura projetizada; 
Similaridade de projetos - quanto menos similares forem os projetos, mais sentido novamente faz a estrutura projetizada; quando os projetos são muito parecidos, mais sentido faz a estrutura funcional;

$>$ Complexidade do trabalho - estruturas funcionais estão mais aptas a manter uma base de conhecimento técnico; estrutura projetizadas são mais lentas e inapropriadas para manter a base de conhecimento quando se passa de um projeto para outro. Em longo prazo, caso a manutenção da base do conhecimento técnico seja importante, as estruturas funcionais seriam mais indicadas;

> Previsibilidade dos projetos - a natureza temporária dos projetos torna difícil para as empresas determinar a quantidade de pessoas e projetos. Se isto for combinado com a inabilidade de prever o volume de projetos que a empresa terá, ficará duplamente difícil prever a quantidade de pessoas que a empresa necessitará em seu quadro de funcionários. Para empresas deste tipo, são mais recomendáveis as estruturas projetizadas. À medida que essa previsibilidade aumenta, menos necessidade a empresa terá das estruturas projetizadas.

Segundo o PMI (2004), organizações cuja receita é obtida principalmente da realização de projetos para terceiros sob contratos (ex.: empresas de engenharia, consultores, empreiteiros), estão mais propensas a utilizar estruturas voltadas a projetos.

Meredith e Mantel (2000), concluem também que, apesar da escolha da estrutura organizacional ser determinada pela situação dos projetos da empresa, a decisão final ainda é suscetível a uma análise intuitiva realizada por quem tem a responsabilidade por tomar a decisão final da escolha.

No item seguinte são apresentados os fatores que afetam o posicionamento do EGP dentro de uma estrutura organizacional.

\subsubsection{O Posicionamento do EGP na Estrutura Organizacional}

Rad e Raghavan (2000) afirmam que o EGP pode ter papel importante em qualquer um dos três tipos de estruturas organizacionais: funcional, matricial e projetizada. $O$ 
PMI (2004) concorda com esta afirmação e complementa dizendo que a possibilidade de ocorrência de um EGP é maior à medida que se caminha na direção da estrutura projetizada, conforme a Tabela 9.

A grande questão do EGP é onde ele deve ser inserido na estrutura organizacional.

Para as estruturas organizacionais apresentadas nos itens anteriores, o PMI (2004) sugere o posicionamento do EGP da seguinte forma: para a estrutura projetizada (Figura 10), haveria uma caixa adicional entre a camada dos gerentes de projetos e a camada do executivo-chefe; para uma estrutura matricial forte (Figura 12), o "chefe de gerentes de projetos" normalmente seria o gerente do EGP; enquanto que, para as estruturas matriciais fraca e balanceada (Figura 11 e Figura 13 respectivamente), o EGP normalmente não se reportaria diretamente ao executivo-chefe.

Porém, existem três outros fatores que podem influenciar fortemente 0 posicionamento do EGP dentro da estrutura organizacional. O primeiro é a análise se um único EGP será suficiente para atender as demandas da organização. O segundo é a definição de que os gerentes de projetos estarão ou não sob a responsabilidade do EGP. E o terceiro é a associação entre as funções com o nível de autoridade necessária ao EGP.

O primeiro desses fatores é analisar se um único EGP é suficiente para atender as demandas da organização. Numa pesquisa realizada por Hobbs e Aubry (2007), eles identificaram que muitas organizações têm mais que um EGP. Segundo esta pesquisa, foi constatada que $47 \%$ dos casos há mais de um EGP na organização. Segundo Litke (1995) apud Patah (2004), a utilização de um único EGP em empresas com muitos projetos pode ocasionar problemas de comunicação, uma vez que a quantidade de pessoas envolvidas é muito grande. Neste caso, o autor sugere que sejam implantados EGP separados, específicos para cada divisão da organização, porém com as mesmas diretrizes básicas. Outra situação a ser considerada é a diversidade geográfica na qual o EGP pode se deparar. Em empresas de grande porte, pode ser necessária a constituição de EGP regionais para atender demandas específicas (BLOCK E FRAME, 1998). 
Os dois outros fatores que influenciam o posicionamento do EGP na estrutura organizacional são tratados nos próximos itens.

\subsection{A Função Gerente de Projetos dentro ou fora do EGP \\ O Gerente de Projetos tem um papel muito importante na condução dos projetos, sendo responsável muitas vezes pelo sucesso ou não do empreendimento.}

A influência dos Gerentes de Projetos na organização é um assunto chave e que deve ser analisado em conjunto com a definição da Estrutura Organizacional e das responsabilidades que o EGP terá na empresa.

As grandes questões em torno da figura do Gerente de Projetos são a definição de qual poder e autoridade este terá na efetiva gestão dos empreendimentos e em que lugar da estrutura organizacional ele estará estabelecido. O Gerente de Projetos terá toda liberdade e poder para gerenciar o projeto? Ou ele fará o papel de um Integrador, responsável por acompanhar e gerenciar o projeto como um todo, mas sem poder formal sobre seus colaboradores?

Essa definição é obtida da determinação da estrutura organizacional. Se for escolhida uma estrutura funcional, o poder sobre os funcionários estará na gerência funcional. Enquanto que, se a escolha for de uma estrutura projetizada, o poder estará com o gerente de projetos. Já as estruturas matriciais oferecem uma grande variedade de opções de compartilhamento de poder. As mais fracas levarão o poder para as gerências funcionais e as mais fortes manterão o poder com o gerente de projetos.

O ponto a ser discutido é a análise conjunta da possível estrutura organizacional com a cultura organizacional da empresa. A cultura organizacional da empresa é compatível com a atuação de um gerente de projetos com total poder sobre o empreendimento? Ou a cultura organizacional é compatível no máximo com a atuação da figura do "Integrador do Projeto"? 
Nesta dissertação, é utilizado o termo "Integrador do Projeto" para se referir à pessoa que tem a função do Gerente de Projetos, mas não tem poder para atuar como o responsável geral pelo projeto. A responsabilidade estaria na gerência funcional. Cabe ao Integrador do Projeto a responsabilidade por fazer a integração do projeto, acompanhando a execução de todas as tarefas e promovendo a troca de informações entre todos os envolvidos. O termo Integrador do Projeto é mais caracterizado nas estruturas organizacionais funcional e matricial fraca.

Portanto, uma das grandes decisões a ser tomadas é se o Gerente de Projetos ficará alocado dentro do EGP ou nas gerências funcionais. Na pesquisa realizada por Hobbs e Aubry (2007), eles identificaram que 31\% das organizações disseram que $100 \%$ dos gerentes de projetos estão dentro do EGP. Enquanto isso, $29 \%$ das empresas disseram não ter nenhum gerente de projetos dentro do EGP, conforme mostra a Figura 14. Visto de outra forma, a pesquisa mostra que 46\% dos EGP têm menos de $25 \%$ dos gerentes de projetos dentro dele; e $40 \%$ tem mais de $75 \%$ dos gerentes de projetos alocados no EGP. Isso mostra a extrema variedade de formas de organizar a estrutura dos EGP.

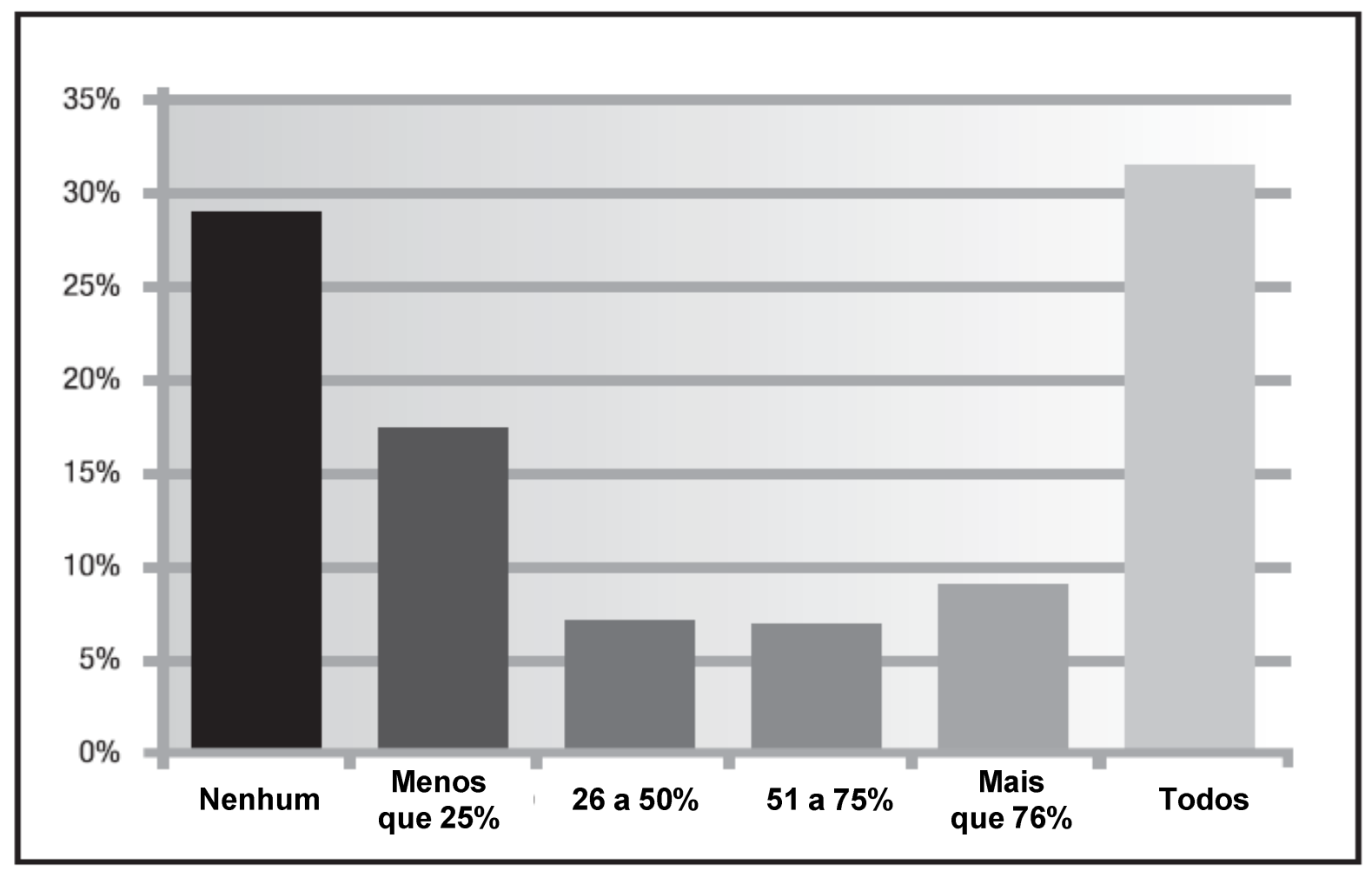

Figura 14: Porcentagem de gerentes de projetos dentro do EGP (Fonte: Hobbs e Aubry, 2007) 
Um outro ponto de discussão é qual o perfil ideal dos gerentes de projetos que trabalham no EGP. Rad (2001) relembra o debate existente se o perfil do gerente de projetos deve ser mais técnico ou mais gerencial. Ele afirma que o ideal é um balanço entre os dois perfis, pois os dois são importantes e necessários. Uma falha em algum destes perfis pode levar o projeto ao fracasso.

Uma das funções de um EGP é definir e implementar as competências necessárias para os gerentes de projetos. Rad (2001) diz que a determinação destas competências é fortemente influenciada pelas necessidades, estratégias e cultura da organização. Portanto, estas influências devem ser analisadas antes da constituição do EGP. Ainda segundo Rad (2001), uma das alternativas do EGP é encontrar os melhores gerentes de projetos dentro da empresa. Porém, para tanto, ele alerta que a escolha dos gerentes de projetos deve ser feita pela análise crítica, realista e documentada da performance desse gerente nos projetos, tendo o cuidado de não escolher o gerente apenas pelo seu sucesso aparente.

Rad e Raghavan (2000) lembram também que há a necessidade de se definir como o EGP irá conseguir os seus gerentes de projetos. Segundo eles, as opções seriam: desenvolver os gerentes de projetos já existentes na empresa; contratar gerentes de projetos experientes do mercado; e/ou terceirizar os serviços para gerentes de projetos contratados.

No item seguinte é apresentada a análise da associação entre as funções e o nível de autoridade designado ao EGP.

\subsection{Associação entre Funções e Autoridade}

Um outro item com forte influência no posicionamento do EGP dentro da estrutura organizacional vem da análise da associação entre as funções e a autoridade designadas ao EGP. 
Nas análises críticas realizadas no item 3.3.5 foi proposto que o planejamento do EGP tratasse separadamente os assuntos funções (responsabilidade) e autoridade, sendo estes depois associados, permitindo dessa forma uma caracterização do EGP voltada às necessidades particulares da empresa.

Como as possibilidades de combinação das funções com o nível de autoridade são inúmeras, torna-se importante entender como essa associação afeta as possibilidades de posicionar o EGP na estrutura organizacional e quais são os reflexos deste posicionamento na atuação do EGP para executar as responsabilidades a ele atribuídas.

Dessa forma, o primeiro passo seria a definição das funções que seriam designadas ao EGP. Em seguida é necessário verificar como cada uma das funções pode impactar na autoridade a ser designada ao EGP.

A primeira análise a ser feita é entender como cada função atribuída ao EGP tem responsabilidade sobre os resultados dos projetos. Para compreender melhor este impacto, é proposta pelo autor dessa dissertação uma classificação das funções em três categorias:

$>$ Funções atribuídas ao EGP que tem responsabilidade direta pela execução dos projetos: são as funções que dão ao EGP a responsabilidade direta pela execução dos projetos, como a "Gestão da Execução" e o "Gerenciamento de Múltiplos Projetos". Neste caso, o EGP e os gerentes de projetos têm a responsabilidade pelos objetivos e resultados finais dos projetos.

Funções atribuídas ao EGP que tem responsabilidade indireta pela execução dos projetos: são funções executadas pelo EGP de grande importância para os resultados dos projetos, mas que não atribuem ao EGP a responsabilidade final pelos resultados dos projetos. São funções como "o fornecimento de gerentes de projetos aos empreendimentos", "o planejamento do empreendimento" e a "gestão estratégica". Estas funções são vitais à execução do empreendimento, mas, em última instância, a responsabilidade pelo resultado final do projeto está com quem tem a função pela execução direta dos projetos. 
Funções atribuídas ao EGP que tem responsabilidade por apoiar a gestão de projetos: são as funções executadas pelo EGP que tem o intuito de organizar e divulgar as práticas de gestão de projetos pela organização. São as típicas funções ligadas ao EGP do tipo "Centro de Excelência". São funções que apóiam, mostram como fazer, treinam, promovem mudança de cultura, ou seja, tentam influenciar outras pessoas da empresa a trabalharem de um determinado modo, acreditando que assim podem obter melhores resultados nos empreendimentos.

A Tabela 10 mostra como ficam os Grupos de Funções da Tabela 10 classificada conforme esta proposição.

\begin{tabular}{|c|l|c|c|c|}
\hline \multicolumn{1}{|c|}{ Grupo de Funções } & $\begin{array}{c}\text { Execução } \\
\text { Direta } \\
\text { dos } \\
\text { Projetos }\end{array}$ & $\begin{array}{c}\text { Execução } \\
\text { Indireta } \\
\text { dos } \\
\text { Projetos }\end{array}$ & $\begin{array}{c}\text { Apoio } \\
\text { nos } \\
\text { Projetos }\end{array}$ \\
\hline 1 & Gerenciamento Estratégico & $\mathbf{X}$ & \\
\hline 2 & Gerenciamento de Múltiplos Projetos & & \\
\hline 3 & Gestão de Recursos & $\mathbf{X}$ & & \\
\hline 4 & Gestão da Execução & & $\mathbf{X}$ & \\
\hline 5 & Planejamento & & & $\mathbf{X}$ \\
\hline 6 & Monitoramento e Controle do Desempenho & & $\mathbf{X}$ \\
\hline 7 & Desenvolvimento das Competências e Metodologias & & & $\mathbf{X}$ \\
\hline 8 & Ferramentas & & & $\mathbf{X}$ \\
\hline 9 & Aprendizado Organizacional & & $\mathbf{X}$ & \\
\hline 10 & Interface com Clientes & & \\
\hline
\end{tabular}

Tabela 10: Grupos de Funções x Responsabilidade sobre os resultados dos projetos (Fonte: autor)

Considerando que o EGP é formado pela combinação destes Grupos de Funções, que pode ser feita de forma livre (qualquer tipo de combinação), conclui-se que, dependendo como ele é formado, haverá uma influência diferente na estrutura organizacional da empresa, e, consequentemente, no local de posicionamento do EGP dentro desta estrutura organizacional.

Dessa forma, novas análises críticas podem ser apresentadas: 
Funções atribuídas ao EGP que tem responsabilidade por apoiar a gestão de projetos: neste caso, o posicionamento do EGP na estrutura organizacional não tem impacto muito alto. Isto porque as suas funções estão ligadas ao processo de convencimento das pessoas ou ao processo de prestação de algum serviço ao restante da empresa. Desse modo, em qualquer local da estrutura organizacional ele poderia realizar as suas atividades. Ou seja, o EGP poderia ser posicionado em qualquer local da estrutura organizacional. O que diferencia 0 local de posicionamento do EGP neste caso é a força que se deseja dar a ele. Se o EGP for posicionado na parte de baixo da hierarquia organizacional, este não terá muito poder de influência perante o resto da organização, pois não seria explícito o apoio direto da alta administração. Teria assim uma atuação mais voltada ao planejamento, controle e treinamentos. Porém, uma vez o EGP posicionado numa parte mais alta da hierarquia organizacional, este terá mais força de atuação e poder de influência perante o resto da organização, pois seria mais explícito o apoio da alta administração. Teria assim uma atuação mais voltada à mudança de cultura, desenvolvimento metodológico e melhoria contínua.

Funções atribuídas ao EGP que tem responsabilidade direta pela execução dos projetos: para estas funções que tem responsabilidade direta pela execução dos projetos, o posicionamento do EGP na estrutura organizacional tem impacto muito alto. Sendo do EGP a responsabilidade pelos resultados do projeto, o EGP tem que estar posicionado de forma que reflita o real poder que deve ter sobre os projetos. O posicionamento do EGP na estrutura organizacional irá influenciar neste caso na determinação de qual estrutura organizacional é a mais apropriada: funcional, matricial ou projetizada. No caso, por exemplo, do EGP assumir a responsabilidade direta pela execução dos projetos (Gestão da Execução), o EGP deveria ser inserido numa estrutura matricial forte ou projetizada. Ou seja, o posicionamento do EGP na estrutura organizacional se torna importante, pois é isto que irá dar força ou não para a realização das funções a ele atribuídas. 
> Funções atribuídas ao EGP que tem responsabilidade indireta pela execução dos projetos: para estas funções, a influência do posicionamento do EGP na estrutura organizacional é algo intermediária entre as duas influências descritas anteriormente. De acordo com as necessidades da empresa, este grupo de funções poderia ser colocado também em qualquer ponto da estrutura organizacional. Porém, pelo fato de algumas de suas funções serem estratégicas, é recomendável que este posicionamento esteja próximo da alta administração. A exceção fica para a função "Planejamento" que não há a necessidade de estar próxima à alta administração.

Como as possibilidades de combinação de funções e posicionamento da estrutura organizacional são inúmeras, fica evidente a importância do entendimento do conceito da relação função (responsabilidade) x autoridade para a determinação de como deve ser constituído o EGP para que este possa atender as reais necessidades da empresa.

\subsubsection{A Influência da Cultura Organizacional}

Um dos fatores fundamentais na implantação de um Escritório de Gerenciamento de Projetos é o seu alinhamento com a Cultura Organizacional da empresa. Dinsmore (2002) e Crawford (2002) associam a implantação de um EGP a um processo de gestão da mudança de cultura organizacional. Trata-se de aprender a lidar com as resistências das pessoas da organização. Block e Frame (1998) dizem que a implantação de um EGP requer muita "sensibilidade política" de quem conduz a implantação, pois muitas pessoas irão resistir a idéia de sua implantação.

Schein (2001) apud Fleury e Sampaio (2002) define cultura organizacional como "o conjunto de pressupostos básicos que um grupo inventou, descobriu ou desenvolveu ao aprender como lidar com os problemas de adaptação externa e integração interna e que funcionou bem o suficiente para ser considerado válido e ensinado a novos membros como a forma correta de perceber, pensar e sentir em relação a esses problemas". 
Crawford (2002) define cultura organizacional como um conjunto de conviç̧ões, valores e expectativas compartilhadas. Nela estão inclusas as políticas, procedimentos, hábitos, rotinas e outras coisas que definem como as coisas são feitas na organização.

O PMI (2004) também concorda que a maior parte das organizações desenvolve sua própria cultura, e que elas são exclusivas e descritíveis. Essa cultura se reflete em diversos fatores, tais como: normas, crenças, expectativas e valores compartilhados; políticas e procedimentos; visão das relações de autoridade; ética do trabalho e horas de trabalho. Essas culturas organizacionais podem ter influência direta no projeto, como por exemplo: a) "uma equipe que propõe uma abordagem pouco usual ou de alto risco tem maior probabilidade de garantir a aprovação em uma organização agressiva ou empreendedora"; b) "um gerente de projetos com estilo altamente participativo provavelmente encontrará problemas em uma organização com hierarquia rígida, enquanto um gerente de projetos com estilo autoritário também enfrentará problemas em uma organização participativa".

Em uma implantação de EGP, Block e Frame (1998) lembram que nem todos da organização irão abraçar a idéia de implantar um EGP. Eles dizem que a equipe do EGP deve compreender que encontrará muito ceticismo e resistência às suas ações. Muitos vão achar que esta é uma despesa desnecessária e que não vale a pena implantá-lo, principalmente se for uma época de recursos escassos. Outros irão ver isso como um aumento de burocracia que irá diminuir a velocidade dos negócios da organização. Ainda outros irão ver como um processo de retirada de poder das mãos de uns para transferi-los a outros. Crawford (2002) lembra também que num processo de mudança cultural dificilmente haverá consenso entre as pessoas da organização.

Segundo Block e Frame (1998), uma forma de buscar diminuir estas resistências é investir em um processo de comunicação que reforce as necessidades e benefícios que o EGP irá gerar para a organização. Deve ser esclarecido a todos da organização quais são as funções do EGP e como ele irá funcionar. Este processo de esclarecimento não deve acontecer unicamente na fase inicial de implantação do EGP, mas sim durante todo o processo de implantação. 
Uma outra ação que pode ser tomada neste processo de convencimento dos benefícios do EGP é, segundo Block e Frame (1998), identificar quais os questionamentos e provocações as pessoas podem fazer no intuito de inviabilizar a implantação. Dessa forma é possível elaborar respostas para cada questionamento, acalmando assim a inquietação dos céticos. Nesta mesma linha, Crawford (2002) recomenda que sejam construídos cenários de possíveis situações futuras. Dessa forma é possível planejar as devidas respostas e ajustes necessários.

Dinsmore (2001) também sugere algumas atividades operacionais que facilitam este processo:

Validação e motivação inicial:

- Pesquisas e entrevistas para definir uma linha de referência para o projeto de implementação do EGP;

- Uma detalhada estruturação do programa;

- Apresentações para a alta administração;

- Seminários para validação;

- Conversas motivacionais com as principais áreas.

Treinamento e desenvolvimento:

- Seminários para os gerentes de projetos e pessoas-chave em temas como liderança e gerenciamento de projetos.

Treinamento no local de trabalho:

- Definição e priorização dos projetos que serão utilizados como piloto durante a implementação;

- Apoio na implementação para gerentes de projetos.

$>$ Infra-estrutura e sistemas de suporte:

- Interface com os desenvolvedores de software;

- Alinhamento das ferramentas e metodologias.

> Mapeamento da competência profissional:

- Pesquisa para definir uma metodologia de avaliação de competências;

- Entrevistas com profissionais e consolidação dos resultados;

- Estabelecimento de programas de desenvolvimento individuais. 
> Acompanhamento e controle:

- Estabelecimento de critérios de medição;

- Feedback para o time de gerenciamento;

- Proposição de mudanças nas estratégias devido a novos cenários.

Kerzner (2003) alerta que focos de resistência podem ser criados para cada uma das funções que o EGP pretende assumir, pois isto pode ser entendido como uma perda de poder e autoridade por determinadas áreas funcionais. Kerzner apresenta uma forma de classificar estes níveis de resistência, conforme abaixo:

> Baixo Risco: Fácil aceitação pela organização com pouca mudança da balança de poder. Virtualmente sem impacto na cultura corporativa.

$>$ Risco Moderado: Alguma resistência pela cultura corporativa e possibilidade de mudança na balança de poder e autoridade. Alguma resistência precisa ser superada rapidamente e com o mínimo de esforço.

> Alto Risco: Fortes grupos de resistência e definida mudança na balança de poder e autoridade. Forte liderança executiva é necessária para superar a resistência.

Kerzner (2003) apresenta na Figura 15 os típicos níveis de risco apresentados para funções designadas ao EGP. Avaliar estes riscos na fase de planejamento do EGP é essencial para seu sucesso. Ele afirma ser uma estratégia conveniente começar a implantação assumindo as atividades de menor risco com o intuito de reforçar a base e ganhar comprometimento com o EGP. Com o tempo, novas funções podem ser agregadas, saindo então de atividades mais operacionais e caminhando para as atividades mais estratégicas.

Um outro item apresentado por Kerzner (2003) que pode gerar resistências é a forma como o EGP pode padronizar as trocas de informações de projetos dentro da organização. Um sistema eficiente de informações pode apontar falhas em projetos nos quais grupos de pessoas não têm interesse que sejam divulgadas, pois pode significar uma perda de poder por parte delas.

A teoria atual de mudança da cultura organizacional está alinhada com as mudanças necessárias em uma implantação de EGP. Segundo Fischer (2002) o conceito atual é o da transformação da cultura, que pressupõe que o esforço direcionado da 
organização deve estar voltado para o aperfeiçoamento contínuo e não para a estabilidade de normas, padrões e regras previamente instauradas. E que o gestor deve funcionar como facilitador de condições e recursos que propiciem o desenvolvimento permanentemente.

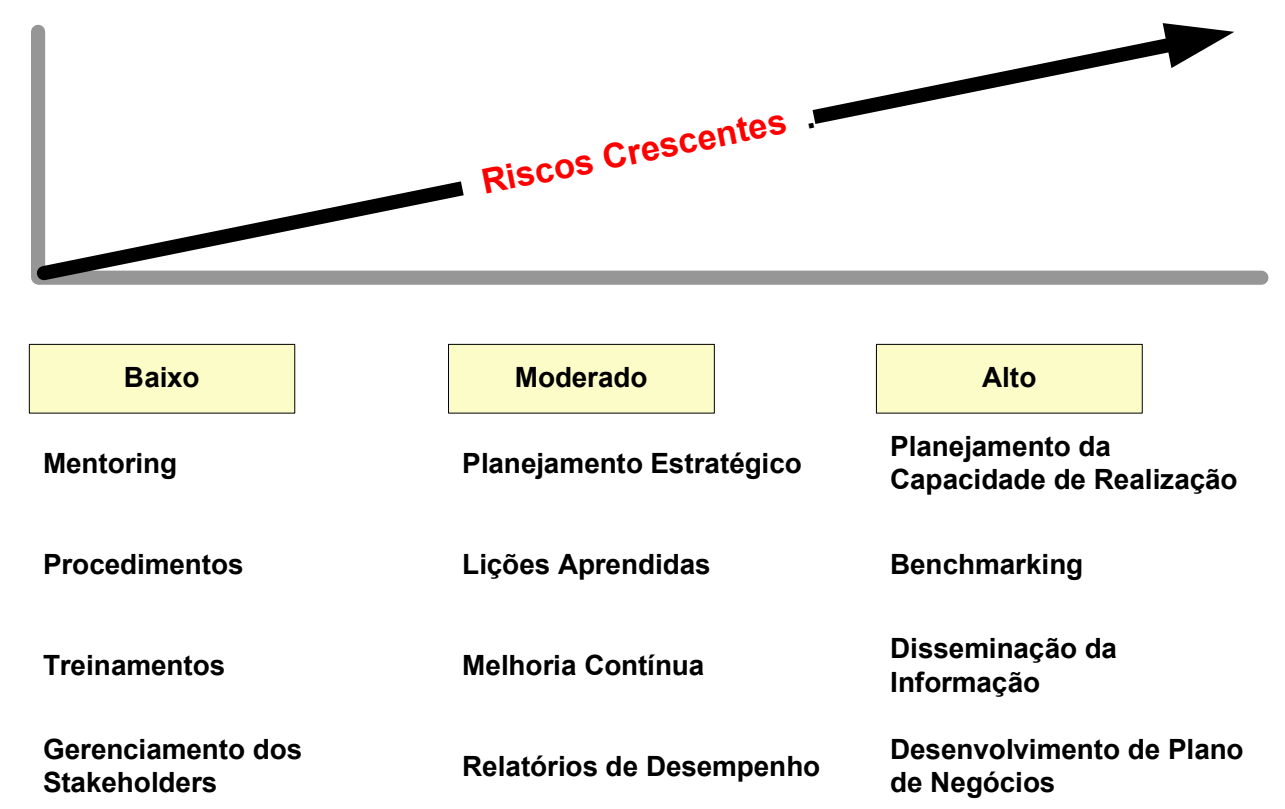

Figura 15: Níveis de Risco por Funções do EGP

(Fonte: traduzido de Kerzner, 2003)

Um outro pressuposto importante vindo da teoria de mudança da cultura organizacional, segundo Fischer (2002), diz que a transformação organizacional só se efetiva com as pessoas, para as pessoas e através do envolvimento e do comprometimento das pessoas. Portanto, os processos e estratégias necessárias para constituição de um EGP devem se fundamentar na valorização e no trabalho das pessoas da organização. Sem elas, nada do que se propõe para o EGP irá funcionar. Esse pressuposto fornece mais força ao raciocínio de Rad e Raghavan (2000) de que as empresas deveriam investir mais suas ações nas pessoas e na integração de departamentos do que na implantação de ferramentas e aplicativos. Não adianta implantar ferramentas se seus usuários não concordarem com a sua utilização.

Fischer (2002) recomenda que o processo de transformação da cultura organizacional seja iniciado sempre com um diagnóstico (auscultação) do cenário atual da organização. Para tal, devem ser realizados: um mapeamento de aptidões e 
resistências à mudança das pessoas envolvidas; mapeamento dos agentes do contexto interno e externo da organização; um levantamento de restritores e alavancadores; uma identificação dos projetos e ações de aperfeiçoamento e treinamento em andamento na empresa; e um levantamento de opiniões e sugestões de pessoas chave da organização, tanto ao nível operacional quanto executivo.

\subsubsection{A Influência da Maturidade em Gestão de Projetos}

Um dos fatores que afetam a implantação de um Escritório de Gerenciamento de Projetos é o nível de maturidade em gestão de projetos da empresa. O modelo de EGP a ser adotado deve estar adequado ao nível de maturidade da empresa, caso contrário, pode tornar-se um processo doloroso e não alcançar os objetivos e resultados propostos (PATAH, 2004).

A maturidade em gestão de projetos é um meio de analisar o quanto a organização já caminhou no sentido de obter a excelência na gestão de seus projetos. Deve-se compreender que todas as empresas atravessam seus próprios processos de maturidade, e que este é um processo que deve preceder a excelência (KERZNER, 2002).

Kerzner (2002) conceitua a maturidade de gestão de projetos como sendo o desenvolvimento de sistemas e processos que são por natureza repetitivos e que garantem uma alta probabilidade de que cada um deles seja um sucesso. Entretanto, processos e sistemas repetitivos não são, por si, garantia de sucesso. Apenas aumentam a sua probabilidade.

Uma empresa pode ser madura em gestão de projetos e não ser excelente. A definição de excelência vai além da definição de maturidade, conforme mostra a Figura 16. As organizações de reconhecida excelência em gestão de projetos criam um ambiente no qual existe um fluxo contínuo de projetos gerenciados com sucesso (KERZNER, 2002). 


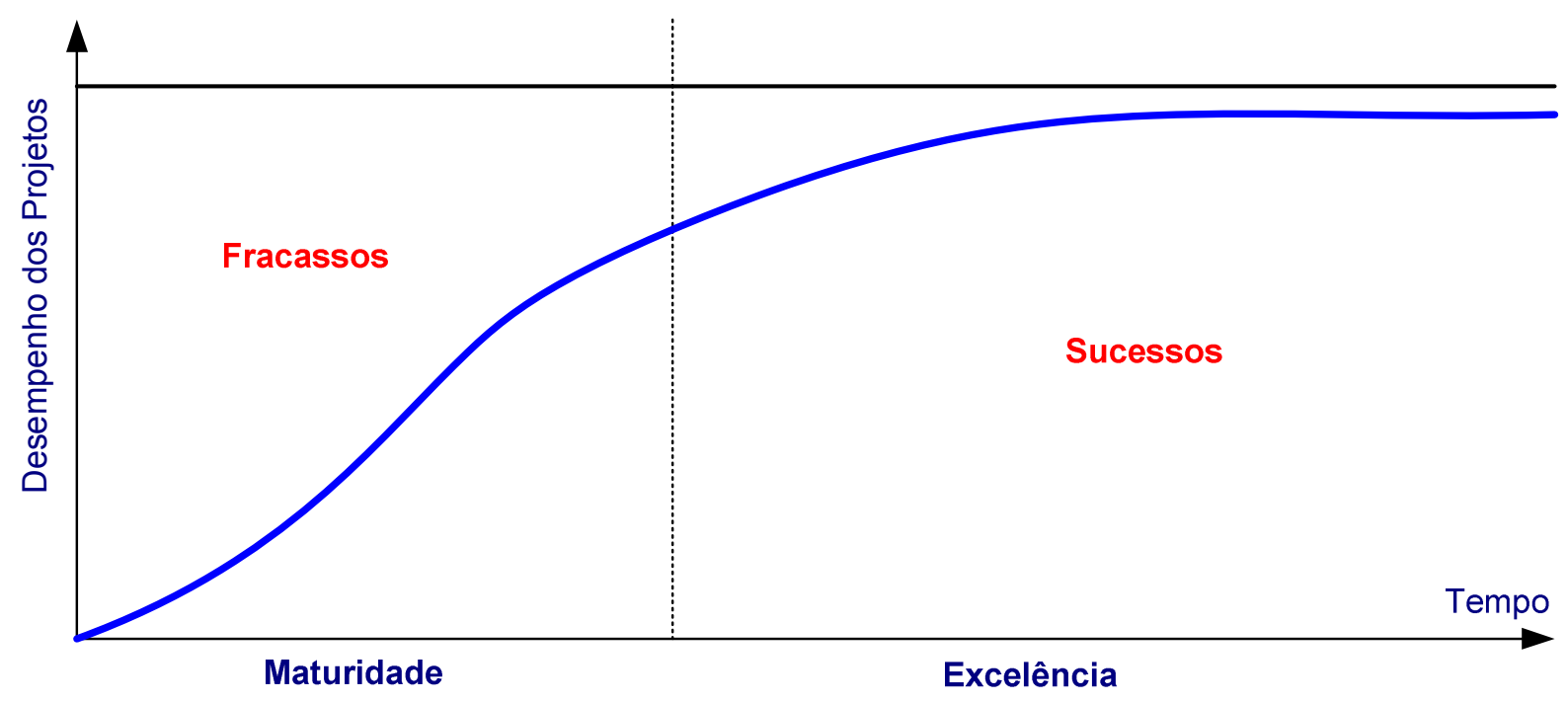

Figura 16: Maturidade e Excelência nas empresas com gestão de projetos (Fonte: adaptado de Kerzner, 2002)

Segundo Kerzner (2002), a definição de excelência pode ser desmembrada em dois componentes. O primeiro requer que um fluxo contínuo de projetos seja administrado com sucesso. Isto não significa que os projetos serão bem sucedidos, apenas que estão sendo gerenciados adequadamente. Como mostra a Figura 16, as empresas excelentes ainda terão um percentual de projetos que serão fracassos. Segundo Kerzner (2002), caso uma empresa descubra que $100 \%$ de seus projetos são bem sucedidos, significa que seus executivos não estão tomando todas as decisões que deveriam. Ainda conforme o autor, o segundo componente da definição de excelência, impõe que as decisões tomadas em projetos separados levem em conta os interesses do projeto e da empresa como um todo. $O$ autor complementa dizendo que geralmente uma empresa comprometida na aplicação da gestão de projetos, leva em torno de 2 anos para atingir a maturidade e mais 5 anos para atingir a excelência em gestão de projetos.

Existem na literatura vários modelos para se medir a evolução da maturidade em gestão de projetos. Dois dos mais conhecidos são o Project Management Maturity Model (PMMM), desenvolvido por Kerzner (2001b) e o Organizational Project Management Maturity Model (OPM3), desenvolvido pelo PMI (2003). No item seguinte são apresentados os conceitos do PMMM. Este modelo é detalhado no item seguinte pois será aplicado no estudo de caso desta dissertação. 


\subsubsection{Project Management Maturity Model (PMMM)}

Um dos modelos de avaliação da maturidade em gestão de projetos é o Project Management Maturity Model (PMMM), proposto por Kerzner (2001b). Este modelo propõe cinco níveis de maturidade, conforme Figura 17:

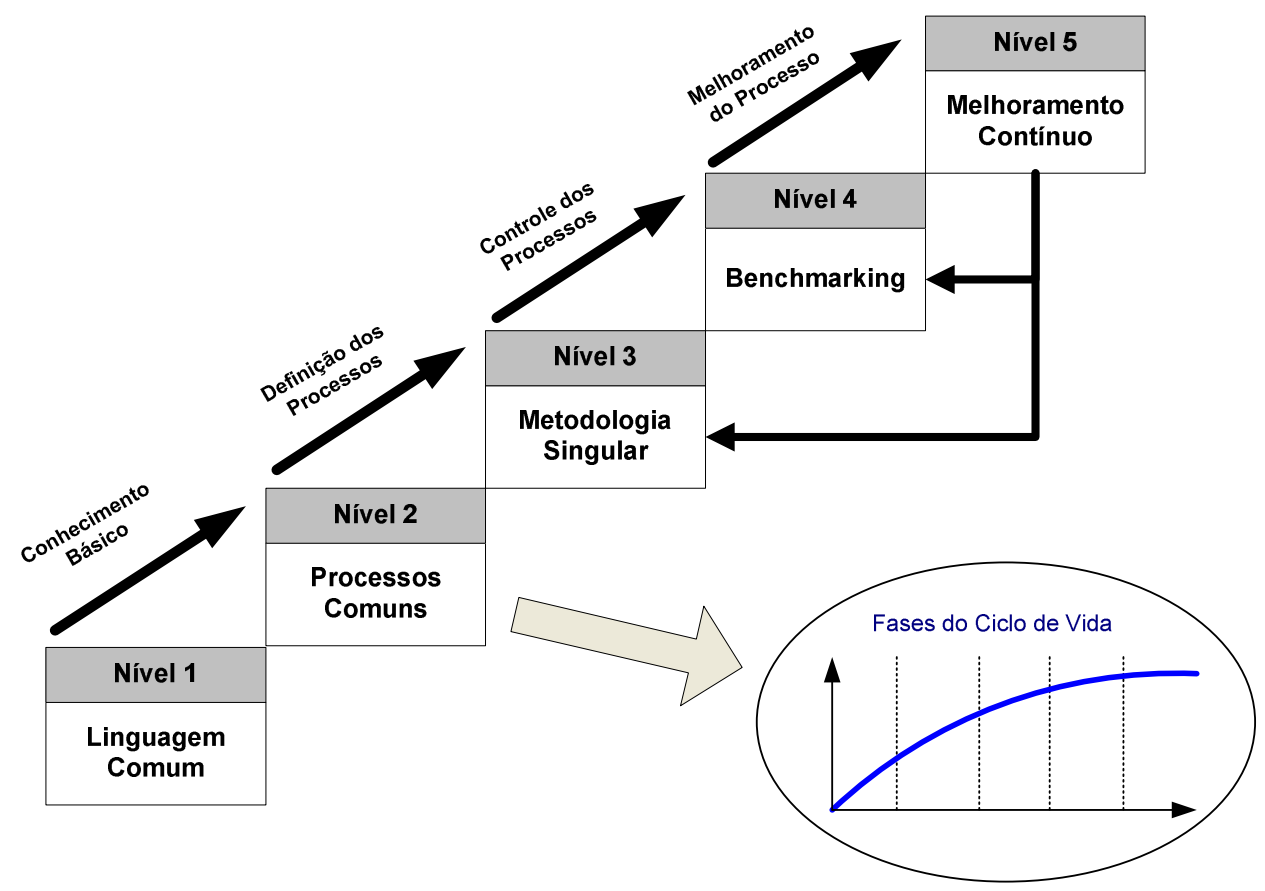

Figura 17: Níveis de maturidade do PMMM

(Fonte: adaptado de Kerzner, 2001b)

As descrições e características de cada nível são descritas abaixo (KERZNER, 2001b):

\section{Nível 1 - Linguagem Comum}

Neste nível a organização começa a reconhecer a importância da gestão de projetos. A organização possui pouco ou nenhum conhecimento da gestão de projetos, mas sente a necessidade de ter um conhecimento básico da disciplina e da linguagem comum que ela proporciona.

Suas características são: uso esporádico do gerenciamento de projetos; nenhum suporte do nível executivo da organização; pequenos grupos de interesse na gestão de projetos; nenhuma tentativa no sentido de reconhecer os benefícios do gerenciamento de projetos; as decisões são tomadas no 
sentido de beneficiar o tomador de decisão, não a empresa como um todo; nenhum investimento em treinamento de gestão de projetos.

\section{Nível 2 - Processos Comuns}

Neste nível a organização faz um esforço combinado para usar a gestão de projetos e desenvolver os processos e metodologias que suportam seu uso efetivo e que possibilitarão que o sucesso de um projeto possa ser repetido nos demais projetos da organização. Para um maior detalhamento do esforço necessário para atingir os objetivos deste nível, este é sub-dividido em fases do ciclo de vida para a maturidade em gestão de projetos, conforme será detalhado mais adiante.

Suas características são: os benefícios do uso da gestão de projetos começam a aparecer, principalmente na diminuição de custos e prazos, sem sacrifício do escopo e qualidade, e com aumento da satisfação do cliente; suporte organizacional de todos os níveis gerenciais, inclusive da alta administração; reconhecimento de que os processos e metodologias proporcionam melhores chances de sucesso nos projetos; reconhecimento que para um perfeito controle de custos há necessidade de adaptações no sistema contábil da empresa; desenvolvimento de um programa permanente de treinamento em gerenciamento de projetos.

\section{Nível 3 - Metodologia Singular}

Neste nível a organização reconhece o efeito da sinergia da combinação de todas as metodologias da corporação em uma metodologia singular, cujo centro é o gerenciamento de projetos. Os efeitos desta sinergia também tornam o controle do processo mais fácil contando com uma única metodologia ao invés de múltiplas metodologias. É considerada uma das etapas de maior dificuldade, pois envolve unificar os processos de toda a organização com base nos processos de gestão de projetos.

Suas características são: todos os processos da organização integrados, com base nos processos de gestão de projetos; cultura organizacional apóia a gestão de projetos; suporte organizacional visível por todos os níveis gerenciais; gerenciamento de projetos informal, com quantidade mínima de 
procedimentos; obtenção de retorno do investimento em treinamentos; excelência comportamental.

\section{Nível 4 - Benchmarking}

Benchmarking é um processo contínuo de comparar as práticas de gestão de projetos da organização com as práticas de outras organizações. Neste nível a organização percebe a necessidade de melhoramento nos processos para manter as vantagens competitivas da organização. A empresa deve decidir de quem fazer o benchmarking e o que procurar neste processo, sendo que este processo deve ser realizado em uma base contínua.

Suas características são: dedicação ao processo de benchmarking; benchmarking realizado em indústrias similares e não similares; benchmarking quantitativo (processos e metodologias) e qualitativo (culturas).

\section{Nível 5 - Melhoramento Contínuo}

Neste nível a organização avalia as informações obtidas através do benchmarking e implementa as mudanças necessárias para melhorar sua metodologia singular (nível 3). Posteriormente são realizados novos processos de benchmarking (nível 4), de tal forma que a excelência em gestão de projetos torna-se uma jornada sem fim.

Suas características são: presença de arquivos de lições aprendidas; conhecimento aprendido de projetos anteriores é transferido para os novos projetos e equipes; desenvolvimento de um programa de mentoring; entendimento que a excelência em gestão de projetos é um processo contínuo.

Kerzner (2001b) define que o Nível 2 (Processos Comuns), pode ser sub-dividido nas fases do ciclo de vida para a maturidade em gestão de projetos. São cinco as fases do ciclo de vida da maturidade, conforme Figura 18: 


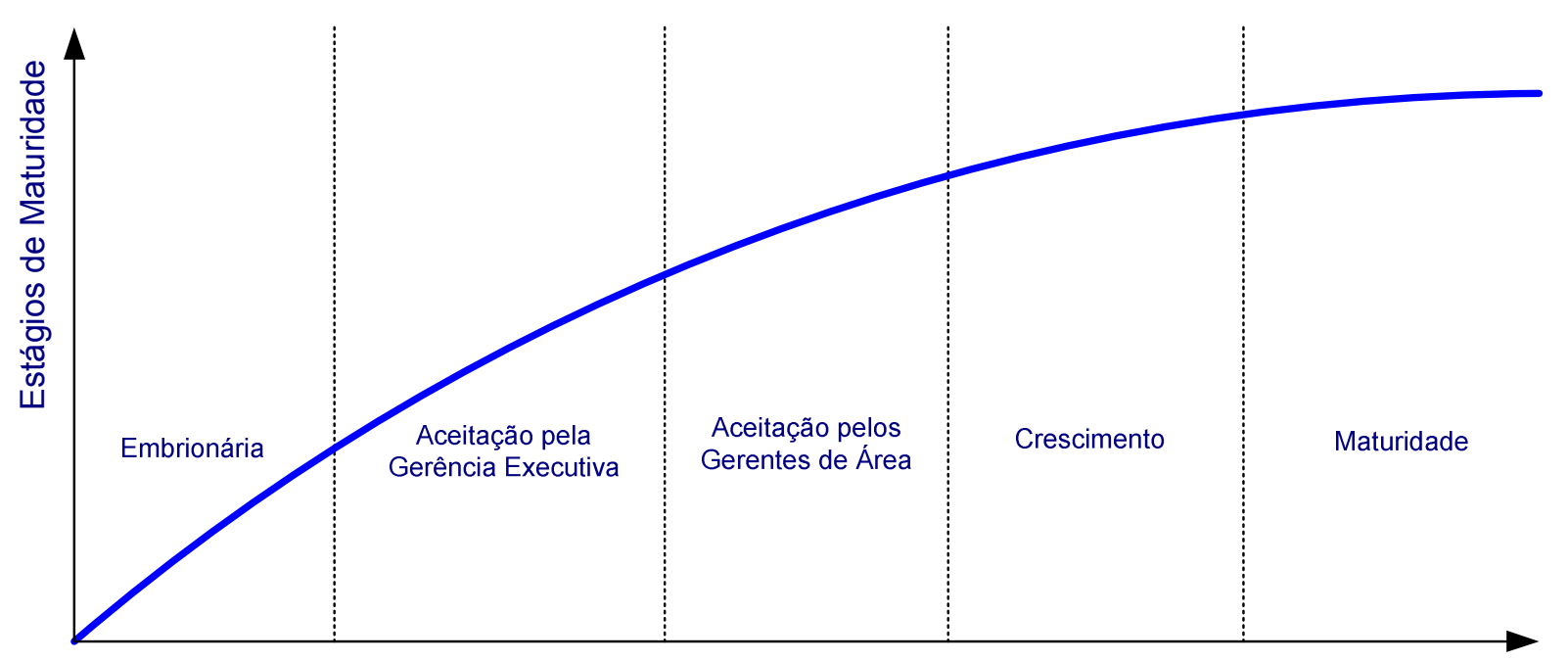

Fases do Ciclo de Vida

Figura 18: Fases do Ciclo de Vida para Maturidade em Gestão de Projetos

(Fonte: adaptado de Kerzner, 2001b)

Segundo Kerzner (2001b), as características de cada fase do ciclo de vida são descritas abaixo:

\section{Fase 1 - Embrionária}

É onde ocorre o reconhecimento por parte da organização dos benefícios que a gestão de projetos pode oferecer. Este reconhecimento costuma ocorrer primeiro nos níveis gerenciais baixo e médio. O conceito da gestão de projetos precisa ainda ser "vendido" à alta administração.

Suas características são: reconhecimento da necessidade da gestão de projetos; reconhecimento dos benefícios potenciais da gestão de projetos; reconhecimento da aplicação da gestão de projetos em várias partes dos negócios da empresa; reconhecimento do que precisa ser feito para implantar a gestão de projetos.

\section{Fase 2 - Aceitacão pela Gerência Executiva}

Aceitação pela gerência executiva (alta administração) dos benefícios da gestão de projetos.

Suas características são: obtenção de apoio visível dos executivos; garantir que os executivos entendam a gestão de projetos; estabelecimento de patrocinadores (sponsor) no nível executivo; garantir dos executivos que eles estão dispostos a mudar a maneira de conduzir os projetos. 


\section{Fase 3 - Aceitacão pelos Gerentes de Área}

Aceitação pelos gerentes de área dos benefícios da gestão de projetos.

Suas características são: obtenção de apoio visível dos gerentes de área; obtenção do comprometimento dos gerentes de área pela gestão de projetos; garantir que os gerentes de área entendam a gestão de projetos; garantir que os gerentes de área estejam dispostos a liberar seus funcionários para treinamentos em gestão de projetos.

\section{Fase 4 - Crescimento}

É onde ocorre o início da criação dos processos de gerenciamento de projetos. Algum esforço desta fase pode ocorrer em paralelo às três fases anteriores, mas ela só estará concluída com a conclusão das três fases anteriores. Esta é considerada a fase mais crítica.

Suas características são: desenvolvimento do ciclo de vida de projetos da empresa; desenvolvimento da metodologia de gestão de projetos da empresa; obtenção do comprometimento das pessoas da organização pela realização de um planejamento efetivo; minimização das mudanças de escopo; seleção de um software de gestão de projetos que dará suporte à metodologia.

\section{Fase 5 - Maturidade}

É também chamada de "fase de maturidade inicial".

Suas características são: desenvolvimento de um sistema integrado de controle do custo e cronograma; integração do controle de custo e cronograma; desenvolvimento de um programa permanente de treinamento em gerenciamento de projetos.

Segundo Kerzner (2001b), tanto os níveis de maturidade quanto as fases do ciclo de vida não necessitam obrigatoriamente serem realizados numa seqüência. Eles podem e normalmente costumam ser sobrepostos. A magnitude dessa sobreposição é baseada na quantidade de risco que a organização está disposta a tolerar. 
A avaliação de cada um dos níveis de maturidade é feita através da aplicação de questionários, encontrados em Kerzner (2001b). Existem cinco questionários, um para cada nível de maturidade.

Kerzner (2001b) apresenta também um levantamento das formas mais comuns de resistência, de acordo com o nível de maturidade:

Nível 1 - Linguagem Comum: a resistência à mudança resulta da crença das gerências de que a implantação da gestão de projetos irá causar um choque cultural onde as gerências funcionais irão perder parte ou toda a autoridade sobre os projetos para os gerentes de projetos. Como resultado, várias desculpas aparecem tentando mostrar que a gestão de projetos não é necessária para a empresa. Surgem comentários do tipo: "Nós não precisamos disto"; "Isto não se aplica aos nossos negócios"; "Vamos viver melhor sem isso".

Nível 2 - Processos Comuns: a resistência é oriunda do medo de que suportar a nova metodologia irá provocar uma troca de poderes e relações de autoridade na empresa. Outro medo é que a nova metodologia irá estabelecer rígidas políticas e procedimentos, novamente causando medo da troca de poderes. Surgem comentários do tipo: "O que nós temos atualmente já funciona bem".

Nível 3 - Metodologia Singular: sempre haverá resistência a utilização da metodologia singular devido ao medo dela promover mudanças de poder na empresa. Gerentes de área vão resistir a uma integração dos custos com o sistema contábil da empresa. Organizações com forte e fragmentada cultura organizacional resistem a serem convertidos numa única cultura corporativa. Algumas organizações criam a cultura de que somente o que está no papel vale. Isto gera uma super ênfase na documentação que é difícil de quebrar.

Nível 4 - Benchmarking: uma forma de resistência comum é a pessoa que desenvolveu a metodologia singular (nível 3) resistir a qualquer tipo de alteração na metodologia, com argumentos do tipo: "isto não foi inventado 
aqui"; "isto não se aplica a nós". Outro tipo de resistência é com o argumento de que o benchmarking foi realizado num tipo de indústria errada.

No item seguinte é discutido como a avaliação da maturidade em gestão de projetos está relacionada e pode cooperar com a implantação de um EGP.

\subsubsection{Relacionamento entre a Maturidade e o EGP}

A maturidade em gestão de projetos da empresa tem uma influência muito grande na implantação de seu EGP. A identificação desta maturidade é uma importante informação que sinaliza onde a empresa está situada e quais são as ações necessárias a se tomar no longo caminho para se obter a excelência em gestão de projetos.

Considerando que se pode utilizar um EGP para se buscar alcançar a excelência em gestão de projetos, torna-se importante identificar como um EGP pode ser customizado para se adequar ao nível de maturidade em gestão de projetos da empresa. Para tanto, torna-se necessário entender como a maturidade influencia esta customização.

Conforme comentário realizado por Andersen, Henriksen e Aarseth (2006), os EGP se desenvolvem numa estrutura dinâmica no decorrer do tempo, sendo que isto estaria relacionado com a maturidade em gestão de projetos da empresa. Ou seja, a maturidade estaria relacionada com a criação das fases de implantação do EGP.

Entretanto, a maturidade por si só não define as fases de implantação do EGP. Os seguintes tópicos também influem na definição destas fases: a cultura organizacional, o diagnóstico da situação atual, a necessidade de gerar valor à organização no curto prazo, as expectativas criadas pelos benefícios esperados e os riscos da implantação. Além disso, a necessidade de atender aos Objetivos Estratégicos do EGP também influi na determinação das fases.

Para uma melhor compreensão, é bom relembrar que na implantação de um EGP, segundo a Figura 5, o primeiro passo é a realização do planejamento estratégico do 
EGP. Nesta etapa, uma das principais decisões é a definição dos Objetivos Estratégicos do EGP, conforme discutido no item 3.3.4. Neste item é recomendado que os objetivos estratégicos do EGP devam ser colocados no tempo, criando as fases de implantação do EGP.

Conforme apresentado no item 3.3.1, uma das ações necessárias para a definição dos Objetivos Estratégicos do EGP é a realização do diagnóstico atual da situação da gestão de projetos na organização. Este diagnóstico identificará os problemas atuais e mostrará quais problemas devem ser solucionados. Entretanto, esta ação está completamente relacionada com a identificação da maturidade em gestão de projetos da empresa. A determinação da maturidade significa justamente identificar onde a empresa está atualmente, significado similar ao da realização do diagnóstico da situação atual. A vantagem de se utilizar os modelos de maturidade em gestão de projetos é a possibilidade de se utilizar um método padronizado, já testado por profissionais de outras empresas e meios acadêmicos.

Ou seja, as atividades conjuntas de realização do diagnóstico atual da empresa e a identificação do seu nível de maturidade influenciam na definição das fases de implantação do EGP. Se a maturidade da empresa já é alta, então ela já pode colocar nas fases iniciais atividades e ações mais complexas. Se a maturidade é baixa, então as fases iniciais devem conter atividades e ações menos complexas e mais fáceis de implantar (Andersen, Henriksen e Aarseth, 2006).

Outro ponto de grande influência na definição das fases de implantação do EGP é o alinhamento com a cultura organizacional da empresa. A implantação de um EGP associa-se a um processo de gestão da mudança de cultura organizacional (Dinsmore, 2002; Crawford, 2002; Block e Frame, 1998). Esta cultura também está associada com a maturidade em gestão de projetos da organização. Uma organização com alto nível de maturidade possui uma cultura organizacional mais adaptada à gestão de projetos. Uma organização com baixo nível de maturidade ainda não possui uma cultura organizacional voltada à gestão de projetos e, consequentemente, seus funcionários promoverão uma maior barreira e resistência à implantação de um EGP. 
Kerzner (2003) trata desse assunto, conforme discutido no item 3.3.8, onde ele apresenta uma forma de classificar os níveis de resistência numa implantação de EGP, de acordo com o tipo de funções designadas ao EGP. Este autor também recomenda que funções que gerem maior nível de resistência sejam colocadas nas fases mais avançadas da implantação do EGP.

$\mathrm{Na}$ mesma linha de raciocínio, os riscos da implantação do EGP também estão associados à definição das fases de implantação do EGP. Kerzner (2001b), conforme discutido no item 3.3.9.1, apresenta as formas mais comuns de resistência conforme o nível de maturidade. As funções, ações e atividades que foram identificadas com maior potencial de risco devem ser colocadas nas fases mais avançadas da implantação, deixando para as fases iniciais, preferencialmente, as que possuem menor potencial de risco.

Dessa forma tem-se a impressão que todas as ações com um maior potencial de riscos devem ser automaticamente colocadas nas fases posteriores da implantação do EGP. Infelizmente esta equação não é automática, pois a empresa necessita resolver seus problemas, independente da quantidade de riscos que ela tenha que enfrentar para resolvê-los. E as expectativas das pessoas da organização, principalmente da alta administração, a respeito dos benefícios que o EGP irá gerar, devem ser atendidas o mais breve possível. Isto gera a necessidade de gerar valor rápido à organização, pois somente desta forma os executivos da empresa continuarão interessados em continuar com a implantação do EGP.

Portanto, torna-se evidente que as fases da implantação do EGP devem ser definidas através da compatibilização de todos os tópicos acima apresentados. Assuntos como a cultura organizacional e os riscos envolvidos tenderão a alongar os prazos de solução. E assuntos como gerar valor no curto prazo e atender às expectativas dos stakeholders quanto aos benefícios que serão gerados, tenderão a encurtar os prazos de solução. A fórmula para a solução desta equação está na habilidade dos membros da equipe de implantação do EGP em negociar junto aos stakeholders o melhor conjunto de funções e atividades versus os riscos e as dificuldades que elas provocam. 
No intuito de fornecer uma visão de como as funções mais comuns poderiam ser designadas ao EGP de acordo com o seu nível de maturidade, o autor propõe a composição apresentada na Figura 19.

Esta composição é apenas uma proposta no intuito de fornecer uma orientação ao leitor, porém, a real composição a ser utilizada na empresa deve ser realizada de acordo com os comentários feitos no corpo de todo este item.

Desta forma, nos níveis iniciais de maturidade (Linguagem Comum (nível 1) e Embrionário (nível 2)), o foco das atividades do EGP seria a realização de treinamentos e a promoção da gestão de projetos pela organização. Durante os níveis de aceitação da gerência executiva e gerentes de área (nível 2), o foco continuaria sendo treinamento e promoção das vantagens da gestão de projetos, sendo que poderiam começar também as atividades de mentoring e os primeiros passos no desenvolvimento da metodologia de gestão de projetos da empresa.

$\mathrm{Na}$ etapa de Crescimento (nível 2), deveria continuar o desenvolvimento da metodologia e iniciar $o$ processo de desenvolvimento da integração dos departamentos. Dependendo das funções designadas ao EGP, poderia também iniciar as atividades de gestão da execução do projeto, suporte ao planejamento, monitoramente e controle dos projetos, alocação de recursos e fornecimento de gerentes de projetos e demais membros da equipe para os projetos.

Na etapa de Maturidade (nível 2), além das funções já iniciadas, poderia iniciar o desenvolvimento de um banco de dados de lições aprendidas, riscos e dados dos projetos, além do desenvolvimento de uma ferramenta de suporte à metodologia. Atividades de consultoria e auditorias poderiam ser realizadas.

$\mathrm{Na}$ etapa de metodologia singular (nível 3), deve ser desenvolvida a metodologia singular da empresa além de outras atividades iniciadas nos níveis anteriores, conforme a Figura 19. Poderiam também ser iniciadas as atividades de planejar a capacidade de realização de projetos da empresa e a gestão de portfólio. 


\begin{tabular}{|c|c|c|c|c|c|c|c|c|}
\hline \multirow[b]{2}{*}{$\begin{array}{c}1 \\
\text { Linguagem } \\
\text { Comum }\end{array}$} & \multicolumn{5}{|c|}{2 - Processos Comuns } & \multirow[b]{2}{*}{$\begin{array}{c}3 \\
\text { Metodologia } \\
\text { Singular }\end{array}$} & \multirow[b]{2}{*}{$\begin{array}{c}4 \\
\text { Bench- } \\
\text { marking }\end{array}$} & \multirow[b]{2}{*}{$\begin{array}{c}5 \\
\text { Melhoria } \\
\text { Contínua }\end{array}$} \\
\hline & Embrionário & $\begin{array}{c}\text { Aceitação } \\
\text { pela } \\
\text { Gerência } \\
\text { Executiva } \\
\end{array}$ & $\begin{array}{c}\text { Aceitação } \\
\text { pelos } \\
\text { Gerentes } \\
\text { de Área }\end{array}$ & Crescimento & Maturidade & & & \\
\hline \multicolumn{2}{|c|}{ Treinamento básico } & \multicolumn{2}{|c|}{$\begin{array}{l}\text { Treinamento para } \\
\text { gerentes e executivos }\end{array}$} & \multicolumn{2}{|c|}{ Treinamento básico } & \multicolumn{3}{|c|}{ Treinamento avançado } \\
\hline \multicolumn{9}{|c|}{ Promover a gestão de projetos dentro da organização } \\
\hline & & \multicolumn{5}{|c|}{ Promover mudança de cultura } & & \\
\hline & & \multicolumn{5}{|c|}{ Aconselhamento (Mentoring) } & & \\
\hline & & & \multicolumn{2}{|c|}{ Desenv. metodologia } & $\begin{array}{c}\text { Melhoria } \\
\text { contínua da } \\
\text { metodologia }\end{array}$ & $\begin{array}{l}\text { Desenv. } \\
\text { metodologia } \\
\text { singular }\end{array}$ & \multicolumn{2}{|c|}{$\begin{array}{l}\text { Melhoria contínua da } \\
\text { metodologia singular }\end{array}$} \\
\hline & & & & \multicolumn{5}{|c|}{ Monitoramento e controle do desempenho dos projetos } \\
\hline & & & & \multicolumn{5}{|c|}{ Desenv. da integração entre departamentos } \\
\hline & & & & \multicolumn{5}{|c|}{ Alocar recursos nos projetos } \\
\hline & & & & \multicolumn{5}{|c|}{ Fornecer profissionais aos projetos (gerente e equipe) } \\
\hline & & & & \multicolumn{5}{|c|}{ Gestão da execução do projeto } \\
\hline & & & & \multicolumn{5}{|c|}{ Fornecer suporte ao planejamento } \\
\hline & & & & & \multicolumn{2}{|c|}{$\begin{array}{c}\text { Desen. base de lições } \\
\text { aprendidas }\end{array}$} & \multicolumn{2}{|c|}{ Gerenciar lições aprendidas } \\
\hline & & & & & \multicolumn{2}{|c|}{ Desenv. base de riscos } & \multicolumn{2}{|c|}{ Gerenciar base de riscos } \\
\hline & & & & & \multicolumn{2}{|c|}{$\begin{array}{c}\text { Desenv. base de dados dos } \\
\text { projetos }\end{array}$} & \multicolumn{2}{|c|}{\begin{tabular}{|c|}
$\begin{array}{c}\text { Gerenciar base de dados dos } \\
\text { projetos }\end{array}$ \\
\end{tabular}} \\
\hline & & & & & \multicolumn{2}{|c|}{ Desenv. software de apoio } & \multicolumn{2}{|c|}{$\begin{array}{l}\text { Melhoria continua no } \\
\text { software de apoio }\end{array}$} \\
\hline & & & & & \multicolumn{4}{|c|}{ Consultoria } \\
\hline & & & & & \multicolumn{4}{|c|}{ Auditorias nos projetos } \\
\hline & & & & & & \multicolumn{3}{|c|}{$\begin{array}{c}\text { Planejar capacidade de realização da } \\
\text { empresa }\end{array}$} \\
\hline & & & & & & \multicolumn{3}{|c|}{ Gestão do portfólio } \\
\hline & & & & & & \multicolumn{3}{|c|}{ Conduzir revisões pós projeto } \\
\hline & & & & & & & Benc & arking \\
\hline
\end{tabular}

Figura 19: Funções do EGP x Nível de Maturidade

(Fonte: autor)

\subsubsection{A Influência dos Fatores Críticos de Sucesso}

A implantação de um Escritório de Gerenciamento de Projetos é uma tarefa complexa e que envolve riscos. Conseqüentemente, há vários fatores críticos de sucesso que necessitam ser considerados no intuito de diminuir os riscos da implantação do EGP. 
Os fatores críticos de sucesso identificados na literatura são descritos na Tabela 11:

Fator Crítico de Sucesso

Referência

Patrocínio da alta administração - sem o apoio da alta administração, não importa o que se faça, a implantação falhará.

Manter a implantação o mais simples possível - atender as questões mais simples para depois pensar nas tarefas mais complexas.

Focar os principais problemas da organização.

Foco em valor - procurar gerar o maior valor possível no menor espaço de tempo.

Estabelecer objetivos incrementais.

Procurar entender os problemas da organização de vários pontos de vista diferentes.

Definição do escopo da mudança: a gestão de projetos melhora vários aspectos da organização, mas não é a resposta para todos os seus problemas.

Realizar testes em projetos pilotos das metodologias desenvolvidas.

Fazer um planejamento detalhado do processo de implantação do EGP.

Reconhecer que a implantação de um EGP é muito mais do que desenvolver e implantar padrões e ferramentas. Ao invés disso, é uma mudança cultural que mexe nos valores pessoais e da organização.

Formar a equipe do EGP com profissionais e gerentes de projetos seniores.

Integração com os sistemas de informação e os processos existentes na empresa.
Crawford (2002)

Crawford (2002)

Crawford (2002)

Crawford (2002)

Crawford (2002)

Crawford (2002)

Verzuh (2005)

Crawford (2002)

Crawford (2002)

Verzuh (2005)

Andersen,

Henriksen e Aarseth (2007)

Patah e Carvalho (2003) apud Patah (2004)

Tabela 11: Fatores Críticos de Sucesso (continua) (Fonte: autor) 


\begin{tabular}{|l|l|}
\hline $\begin{array}{l}\text { Não esquecer de compartilhar as expectativas e objetivos do } \\
\text { processo. }\end{array}$ & Crawford (2002) \\
\hline Comunicar os objetivos e sucessos atingidos pelo EGP. & Crawford (2002) \\
\hline Controlar o desempenho da equipe do EGP. & $\begin{array}{l}\text { Hobbs e Aubry } \\
(2007)\end{array}$ \\
\hline
\end{tabular}

Tabela 11: Fatores Críticos de Sucesso (continuação)

(Fonte: autor)

Um outro fator crítico de sucesso é a forma como se tratam os diferentes tipos de projetos que existem dentro da organização. Rad e Raghavan (2000) sugestionam que uma deficiência da própria teoria de gerenciamento de projetos é não haver uma diferenciação de projetos pelo seu tipo, estratégia ou contexto operacional. Há na literatura um largo conhecimento em como organizar, planejar e controlar os projetos, mas não há diferenciação em como fazer isso para as diferentes indústrias existentes.

Dessa forma, torna-se importante que o EGP seja constituído de forma compatível com os tipos de projetos da organização. Rad e Raghavan (2000) e Crawford (2002) propõem que os projetos sejam classificados e que sejam desenvolvidas metodologias para cada tipo de classificação. Desse modo estaria sendo feita uma diferenciação por tipo de projetos. Os projetos poderiam ser classificados por porte, tipo, quantidade, complexidade, grau de inovação, grau de integração necessária, estrutura organizacional envolvida, tipo de indústria, tipo de recursos necessários ou outras formas que façam sentido à empresa. Por exemplo, poderiam ser desenvolvidas metodologias específicas para projetos de pequeno, médio e grande porte.

Tão importante quanto analisar os fatores que levam ao sucesso da implantação de um EGP, é analisar os fatores que certamente levarão ao seu fracasso. Os fatores críticos de fracasso identificados na literatura são descritos na Tabela 12: 


\begin{tabular}{|l|l|}
\hline $\begin{array}{l}\text { Esquecer os stakeholders chave do processo de implantação: falta de } \\
\text { envolvimento da alta administração e de todos interessados desde o } \\
\text { início, determinando suas necessidades, expectativas e objetivos; }\end{array}$ & $\begin{array}{l}\text { Crawford } \\
(2002)\end{array}$ \\
\hline $\begin{array}{l}\text { Demandar antes de prover: o EGP necessita ser visto como uma } \\
\text { entidade que provê serviços para facilitar a gestão de projetos e não } \\
\text { como uma entidade que apenas cobra informações e ações de outras } \\
\text { áreas; }\end{array}$ & $\begin{array}{l}\text { Crawford } \\
(2002)\end{array}$ \\
\hline $\begin{array}{l}\text { Tentar mudar as pessoas, os processos e as ferramentas da } \\
\text { organização de uma única vez: mudar as três coisas de uma vez é } \\
\text { uma tarefa muito complexa, que deve ser evitada se possível; }\end{array}$ & $\begin{array}{l}\text { Crawford } \\
(2002)\end{array}$ \\
\hline $\begin{array}{l}\text { Adiar a implantação do EGP depois que a decisão foi tomada: } \\
\text { hesitações podem acarretar uma perda de confiança das pessoas no } \\
\text { processo; }\end{array}$ & $\begin{array}{l}\text { Crawford } \\
(2002)\end{array}$ \\
\hline $\begin{array}{l}\text { "Re-inventar" a roda, ignorando idéias, o conhecimento e as } \\
\text { experiências das demais pessoas da organização; }\end{array}$ & $\begin{array}{l}\text { Crawford } \\
(2002)\end{array}$ \\
\hline $\begin{array}{l}\text { Dar prioridade de implantação às ferramentas e aplicativos, ao invés } \\
\text { de concentrar esforços em obter altos níveis de integração entre os } \\
\text { departamentos. }\end{array}$ & $\begin{array}{l}\text { Rad e } \\
\text { Raghavan } \\
(2000)\end{array}$ \\
\hline
\end{tabular}

Tabela 12: Fatores Críticos de Fracasso

(Fonte: autor)

Um dos fatores chave em qualquer implantação de EGP é o apoio ou não da alta administração da empresa. Sem este apoio da alta administração, não é possível conduzir uma implantação deste tipo com sucesso. Alguns dos fatores que justificam essa influência são comentados por Sbragia, Rodrigues e Gonzáles (2002):

> Dificuldade em se justificar o dinheiro investido na implementação do EGP;

> A percepção de que os benefícios da implementação de um EGP são a longo prazo, enquanto que o aumento de carga "burocrática" é imediato, devido à aplicação formal de metodologias de gerenciamento de projetos;

> Os conflitos que devem ser administrados a partir da introdução de um novo grupo que disputará o poder com grupos já estabelecidos na organização. 
Kerzner (2003) acredita que os maiores riscos de fracasso do EGP não acontecem durante a criação do EGP e sim após a sua implantação. Estes riscos seriam:

Número de funcionários: uma vez a organização acreditando nos benefícios oferecidos pelo EGP, há uma tendência natural em aumentar o número de funcionários do EGP, com a crença que uma equipe maior poderá trazer maiores benefícios. Esta crença poderá trazer problemas ao EGP. A situação verdadeira é que o número de funcionários tende a diminuir com o sucesso da implantação do EGP;

> Pessoas "queimadas": sempre existe o risco de funcionários se "queimarem". Utilizar políticas de job rotation ou alocação parcial do tempo dos funcionários pode minimizar essa situação. Não é incomum ver pessoas reportando com "linha sólida" ao gerente funcional e com "linha pontilhada" ao gerente do projeto;

> Excessiva documentação: excessivas metodologias e padronizações podem causar perda de tempo e produtividade. O ideal é utilizar formulários, guias e checklists, ao invés de rígidas políticas e procedimentos;

> Reestruturação organizacional: é natural uma luta de poderes para definir com quem fica o controle do EGP, principalmente o controle sobre os gerentes de projetos;

> Tentativa de servir a todos na organização: a organização precisa estabelecer critérios de onde o EGP irá atuar, já que ele não consegue atuar e monitorar todos os projetos.

\subsubsection{Os Recursos Humanos}

Um dos pontos cruciais na montagem de qualquer Escritório de Gerenciamento de Projetos é a constituição de seu quadro de funcionários.

Este quadro de funcionários deve ser constituído de acordo com o tamanho, o nível que o EGP estará na estrutura organizacional e as responsabilidades que o EGP deverá assumir. Segundo Crawford (2002), os cargos possíveis seriam:

$>$ Diretor

$>$ Gerente de Projetos 
$>$ Mentor

$>$ Planejador

- Especialista em Metodologias

> Bibliotecário ou especialista em documentação

$>$ Coordenador de Suporte Administrativo

> Coordenador de Comunicações

> Coordenador de Controle de Mudanças

$>$ Coordenador de Gerenciamento de Risco

Kate (2000) ainda acrescenta as seguintes funções:

> Analista de Projetos

$>$ Consultor de Projetos

> Gerentes de Projetos e Programas

> Treinador de Gerenciamento de Projetos

Na elaboração da constituição do EGP deve-se lembrar que nem sempre todos os funcionários ficarão alocados dentro do próprio departamento do EGP. Há situações em que se cria um EGP central, com poucas pessoas, e se utiliza representantes das áreas ou gerências funcionais para atuar em conjunto com o EGP central. Esses representantes podem ter as mais diversas responsabilidades, desde elaboração das metodologias até ser um facilitador dentro do departamento.

A pesquisa realizada por Hobbs e Aubry (2007) mostra que a maioria dos EGP tem muito poucas pessoas alocadas, conforme mostra a Figura 20. Aproximadamente $50 \%$ dos EGP têm de 1 a 3 pessoas alocadas em tempo integral.

Um dos principais fatores pelo baixo número de pessoas alocados no EGP é seu custo de overhead. Estas pessoas são overhead e as organizações são muito relutantes em criar despesas do tipo overhead, segundo Hobbs e Aubry (2007). O item custo de overhead é tão crucial que é normal encontrar situações paradoxais em que o EGP é pressionado para realizar diversas funções, mas ao mesmo tempo é pressionado para ter poucos recursos. Este também é um dos motivos por se utilizar a abordagem de ter parte das pessoas do EGP alocadas nas áreas ou gerências funcionais. 


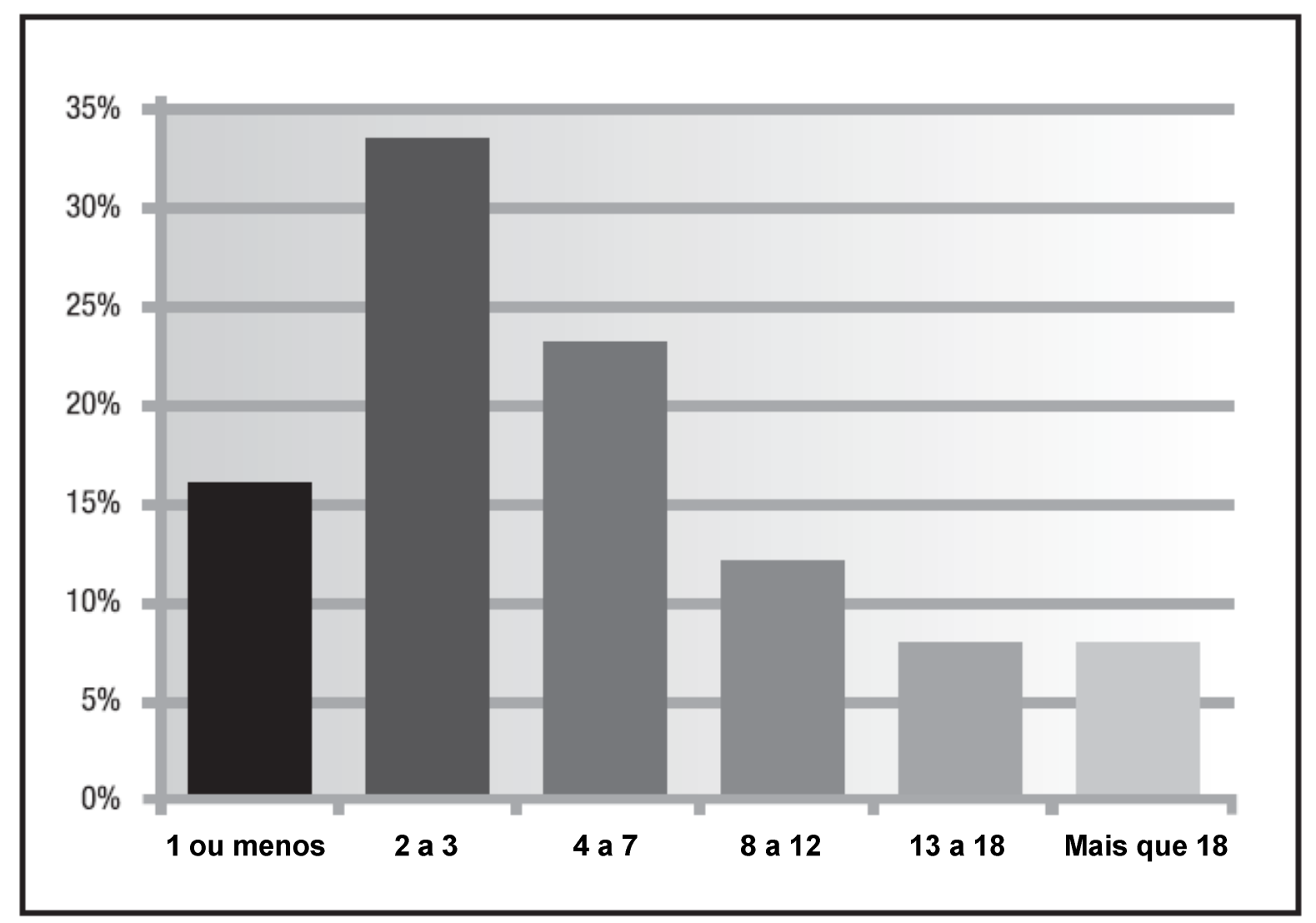

Figura 20: Pessoas alocadas no EGP excluindo os gerentes de projetos (full time equivalent ${ }^{7}$ )

(Fonte: Hobbs e Aubry, 2007)

\subsubsection{Custos da Implantação}

Para a implantação e posterior operação da estrutura de um EGP, durante a fase de planejamento devem ser levantados com bastante rigor todos os recursos e os custos que serão necessários. Estes devem ser viabilizados antes do início dos trabalhos.

A Tabela 13 apresenta vários custos possíveis de ocorrer, porém a equipe do EGP deve analisar se ainda existem outros custos específicos de sua implantação além destes apresentados.

\footnotetext{
${ }^{7}$ Full Time Equivalent: Número equivalente ao de profissionais trabalhando em período integral no projeto.
} 
Custos

Referência

\begin{tabular}{|l|l|}
\hline Recursos Humanos & Patah (2004) \\
\hline Locação de espaço físico para o escritório & Patah (2004) \\
\hline Compra ou locação de mobiliário & Patah (2004) \\
\hline Recursos de informática: hardware, software & Patah (2004) \\
\hline Montagem de biblioteca especializada em gerenciamento de projetos & Patah (2004) \\
\hline Treinamentos da equipe do EGP & Patah (2004) \\
\hline $\begin{array}{l}\text { Treinamentos para os diversos funcionários da organização: gerentes } \\
\text { e equipe de projetos, alta direção, gerentes funcionais, etc. }\end{array}$ & autor \\
\hline Treinamentos em softwares específicos & Patah (2004) \\
\hline Desenvolvimento de ferramentas (softwares) & autor \\
\hline Desenvolvimento das metodologias & autor \\
\hline Elaboração de manuais, apostilas, material de apresentação & autor \\
\hline $\begin{array}{l}\text { Divulgação e Marketing: apresentações, workshops, intranet, material } \\
\text { publicitário }\end{array}$ & $\begin{array}{l}\text { Patah (2004); } \\
\text { autor }\end{array}$ \\
\hline Consultorias & Rad (2001) \\
\hline Viagens & Patah (2004) \\
\hline Gastos da rotina administrativa & autor \\
\hline
\end{tabular}

Tabela 13: Custos da Implantação

(Fonte: autor)

Outro ponto a ser discutido é a alocação dos custos gerados pela implantação do EGP. Patah (2004) lembra que, devido ao fato de vários departamentos serem beneficiados pelo EGP, seria natural que os custos da implantação fossem rateados entre os departamentos. Esta é uma forma comumente utilizada de financiamento dos custos da implantação. Uma outra opção seria o rateio dos custos entre os projetos que se utilizam do EGP. E uma terceira possibilidade ocorre quando o EGP é criado para o suporte a um projeto específico. Neste caso todos os custos seriam alocados diretamente neste projeto. 


\subsection{PLANEJAMENTO DAS FASES}

No item anterior (3.3) foram apresentadas as atividades necessárias para a elaboração do planejamento estratégico do EGP. O processo de planejamento estratégico deve ter sido capaz de definir as funções e autoridade do EGP, qual seu posicionamento na estrutura organizacional, qual sua abrangência de atuação e, principalmente, quais os objetivos a serem atingidos.

As análises realizadas durante o planejamento estratégico podem indicar a necessidade de conduzir o processo de implantação do EGP em fases. Conforme anteriormente apresentado por Andersen, Henriksen e Aaserth (2006), essa estratégia de faseamento é bastante recomendada, pois permite que a estrutura do EGP cresça conforme a evolução de sua maturidade. O ideal é iniciar com uma estrutura simples e com o tempo ir agregando novas funções. De acordo com a Figura 5, estas fases podem, por exemplo, refletir os objetivos de curto, médio e longo prazo.

Uma vez definida as fases da implantação do EGP, cada uma das fases pode ser considerada um projeto (PATAH; CARVALHO, 2003 apud PATAH, 2004). Assim, a implantação do EGP como um todo (todas as fases) pode ser considerado um programa.

Neste momento é necessário detalhar o planejamento da fase vigente. Este planejamento pode ser entendido como o planejamento tático / operacional da implantação e deve ser realizado conforme as práticas da gestão de projetos, podendo ser utilizado as práticas recomendadas, por exemplo, pelo Project Management Institute (PMI) ou pelo International Project Management Association (IPMA). Nesta dissertação serão utilizadas as práticas recomendadas pelo PMI.

Segundo o PMI (2004), o planejamento da fase deve ser iniciado com a elaboração e emissão do Termo de Abertura do Projeto, que é o documento que autoriza o início formal do projeto ou da fase e nomeia o gerente do projeto responsável pela implantação. Neste documento deve estar descrito todos os aspectos do 
planejamento estratégico que devem ser aplicados na fase, principalmente as funções e os objetivos específicos da fase.

Durante o planejamento da fase, devem ser analisadas cada uma das áreas de conhecimento do PMBoK, como o escopo, prazo, custo, qualidade, risco, comunicação, recursos humanos, suprimentos e a integração de todas elas. Este planejamento deve ser consolidado no documento chamado Plano do Projeto (PMI, 2004).

$\mathrm{Na}$ parte referente ao escopo, devem ser detalhadas as funções que o EGP terá nesta fase e como ele realizará essas funções. Deve ser elaborada a declaração de escopo e definida a EAP do projeto (ou fase). Devem ser documentadas as premissas e as restrições impostas ao projeto.

Deve ser realizado um cronograma detalhado das tarefas de implantação que o EGP terá de realizar para atingir seus objetivos, indicando os responsáveis de cada tarefa. É importante também elaborar a "Curva S" do projeto, pois é uma ferramenta útil para o controle da evolução dos trabalhos. Caso o prazo de implantação da fase seja longo, é importante definir objetivos parciais, com prazos menores para facilitar o controle.

Devem ser definidos todos os recursos necessários para a execução das funções propostas ao EGP. Estes recursos devem envolver materiais, equipamentos, serviços, infra-estrutura e principalmente os recursos humanos.

Deve-se realizar um detalhamento dos custos necessários para a respectiva fase e alinhá-los com o orçamento disponível para implantação. Devem ser preparados os controles necessários para acompanhar a evolução dos custos de implantação, como por exemplo, planilhas de controle e o desenvolvimento da "Curva S" de Custos.

$\mathrm{Na}$ parte referente à qualidade do projeto, devem ser documentados os objetivos e as metas do EGP na respectiva fase. Estes devem ser perseguidos durante toda a implantação da fase. 
Todos os recursos humanos necessários para implantação da fase devem ser definidos e documentados no plano de projeto. Devem ser definidas as competências necessárias para a equipe do projeto, definindo os conhecimentos e nível de experiência necessária para a implantação. Neste caso, é importante observar que estes profissionais provavelmente também deverão atuar nas fases seguintes, portanto, o conhecimento e experiências necessárias devem respeitar também todas as fases da implantação. Caso seja identificada a necessidade de capacitação da própria equipe, deve ser elaborado o plano para suprir as necessidades identificadas. Uma das possibilidades de necessidade de capacitação da própria equipe acontece quando a equipe do projeto é nova na organização. Neste caso, torna-se necessário treinar a equipe nos negócios e rotinas operacionais da organização.

$\mathrm{Na}$ parte referente às comunicações, o plano deve prever a forma como serão realizadas as trocas de informações dentro do projeto durante a implantação. Deve ser prevista também a forma como o EGP irá se comunicar com o resto da organização, como irá se apresentar e quais os canais de comunicação estarão disponíveis entre o EGP e o restante da organização. É importante desenvolver também uma análise de todos os stakeholders envolvidos, gerando um plano de ação para atender as necessidades de cada um deles.

Deve também ser definido e documentado o plano de riscos do projeto. Todos os riscos envolvidos na implantação devem ser identificados, sendo gerado um plano de ação para tratá-los. Todos os riscos apresentados no capítulo do planejamento estratégico devem ser considerados e tratados.

No caso de haver a necessidade de aquisição de materiais, equipamentos, serviços ou consultorias, esta deve ser documentada, planejando suas aquisições.

As formas de controle da execução do plano de projeto também devem ser definidas, garantindo com isso que as tarefas do EGP sejam devidamente controladas conforme a implantação de qualquer projeto. 
Com a conclusão da elaboração do plano do projeto, pode-se dar o início da implantação da respectiva fase do EGP.

\subsection{O PROCESSO DE IMPLANTAÇÃO}

Uma vez realizados o planejamento estratégico e o detalhamento das possíveis fases do EGP, inicia-se o processo de implantação.

A execução da implantação deve ocorrer de forma rigorosa e estritamente como foi planejado. Um processo de execução ineficiente pode acabar com todos os benefícios propostos na fase de planejamento. Portanto, é importante que ele seja bem realizado e esteja dentro das ações previstas no planejamento.

Segundo Kaplan e Norton (2001) apud Oliveira (2007), a capacidade de executar as estratégias é mais importante que a qualidade da estratégia em si. Estes autores dizem que apenas $10 \%$ das estratégias formuladas são implantadas com êxito, concluindo que o verdadeiro problema não é a má estratégia, e sim, a má execução da estratégia.

É fundamental estabelecer uma forma de controle de todo o processo de implantação para que qualquer desvio apresentado seja rapidamente identificado e tratado. Controlar as próprias ações do EGP e de sua equipe são fundamentais para garantir a boa execução deste processo.

Kerzner (2002) ainda informa que o planejamento estratégico do EGP é um processo dinâmico e que necessita de reavaliações, feedback e atualizações. Da mesma forma, o planejamento detalhado das fases também necessita de reavaliações. Para Kerzner (2002), os reflexos e resultados obtidos durante o processo de implantação de cada fase devem provocar revisões e adequações no planejamento elaborado.

Mintzberg, Ahlstrand e Lampel (2000) também concordam que na prática, nem todas as estratégias definidas são sempre realizadas. Durante a implantação das 
estratégias, algumas não seriam realizadas enquanto novas surgiriam. Estes autores chamaram de "estratégias deliberadas" aquelas definidas previamente e de "estratégias emergentes" as novas que surgiram durante o processo de implantação. Estes autores consideram que as estratégias emergentes não são necessariamente más, pois elas podem refletir um processo de aprendizado e uma capacidade de reagir a eventos inesperados.

\subsection{A OPERAÇÃO DO EGP}

A fase de Operação inicia-se quando for possível identificar os benefícios propostos no início da implantação do EGP e documentados em seu planejamento estratégico.

Dessa forma comprova-se que os objetivos, metas e compromissos assumidos pelo EGP na sua fase de planejamento foram alcançados e os benefícios gerados à organização são identificados e visíveis por todos os usuários.

Com isso, o conceito fundamental deste ponto em diante é a manutenção dos benefícios gerados pelo EGP. O EGP deve manter ou montar uma estrutura que propicie a manutenção destes benefícios e trabalhe pela busca da melhoria contínua.

Esta fase de Operação está associada com níveis mais altos de maturidade em gerenciamento de projetos e tem como funções características as ligadas às práticas de benchmarking e a todo processo de melhoramento contínuo.

Para as implantações realizadas por fases, este é o momento de iniciar a fase seguinte. Conforme proposto pela Figura 5, no caso de divisão de fases em curto, médio e longo prazo, este é o momento de iniciar a fase de médio ou a de longo prazo.

As equipes do EGP devem ter o cuidado de não cair na tentação de realizar atividades ou fases em paralelo. $O$ intuito e a pressão por gerar a maior quantidade de benefícios no menor prazo possível, podem levar à tentação de iniciar as fases 
seguintes antes de concluir as fases anteriores. Essa ação deve ser evitada, pois envolve um aumento nos riscos da implantação.

Uma vez concluída a implantação de todas as fases, entra-se por completo na fase de operação do EGP. A partir deste momento, o EGP deve-se focar na manutenção dos benefícios gerados, buscando também evoluir na busca da excelência da gestão de projetos na organização.

O capítulo seguinte trata de um estudo de caso realizado para observar, em um caso real, as propostas discutidas neste capítulo. 


\section{ESTUDO DE CASO}

Este capítulo apresenta o estudo de caso do planejamento da implantação do EGP de uma empresa de grande porte. A metodologia de pesquisa utilizada para tal é descrita no capítulo 2. O intuito deste estudo de caso é identificar e analisar os fatores considerados no planejamento deste EGP, confrontando-os com as análises apresentadas no capítulo 3.

Nos próximos itens é apresentada uma visão geral da empresa e de seu EGP e são analisados seu planejamento estratégico, planejamento das fases, sua implantação, os resultados obtidos e as conclusões do estudo de caso.

\subsection{AMBIENTAÇÃO DA EMPRESA E SEUS PROJETOS}

A empresa estudada atua no segmento de logística e transporte, sendo líder de seu setor no Brasil. É parte de uma holding nacional de economia mista sob o controle do governo brasileiro. Por razões de confidencialidade, não é apresentado o nome da empresa, a qual será chamada genericamente de "LogB".

A LogB faturou no ano de 2005 aproximadamente $R \$ 3$ bilhões e possui aproximadamente 5000 funcionários, sendo $30 \%$ próprios e $70 \%$ contratados. As funções de coordenação e as hierarquicamente superiores são todas preenchidas por funcionários próprios.

A empresa tem atuação nacional, com sede no Rio de Janeiro e estrutura administrativa dividida em quatro regionais: São Paulo e Centro Oeste (SPCO), Sul, Sudeste (SE) e Norte e Nordeste (NNE).

A carteira de projetos da empresa do ano de 2007 foi constituída de mais de 2500 projetos, totalizando investimentos superiores a um bilhão de reais. Os projetos apresentam diferentes níveis de complexidade, variando desde simples reformas prediais até a construção de novos terminais logísticos. O porte dos projetos também varia bastante, conforme pode ser observado na Figura 21. 

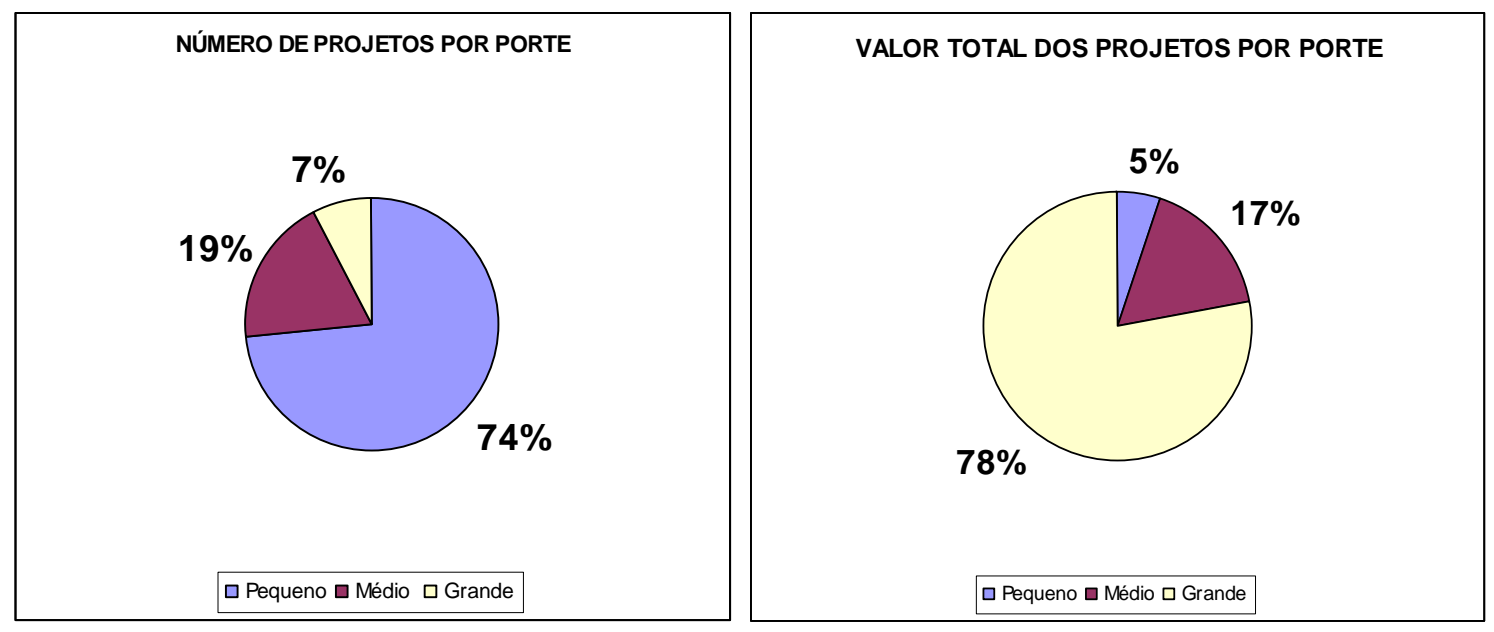

Figura 21: Carteira de Projetos 2007

(Fonte: autor)

O porte do projeto é definido pelo valor total do projeto. São considerados de pequeno porte os projetos com valor total inferior a $R \$ 1.500 .000$. De médio porte são os projetos até $R \$ 10.000 .000$. E os de grande porte são os projetos com valor total superior a $\mathrm{R} \$ 10.000 .000$.

\subsection{VISÃO GERAL DA IMPLANTAÇÃO DO EGP}

Antes de começar a realizar as análises de como foi planejada a implantação do EGP desta empresa, é necessário apresentar uma visão geral de como ocorreu sua implantação, os motivos que levaram a empresa a montá-lo, quais foram as fases de implantação e como a implantação ocorreu. Após a apresentação da visão geral, são apresentadas as análises de como foi realizado seu planejamento, de acordo com os fundamentos teóricos discutidos no capítulo 3.

A Figura 22 busca apresentar todos os grandes movimentos que ocorreram desde as primeiras ações em prol da gestão de projetos até a atual configuração deste EGP. 


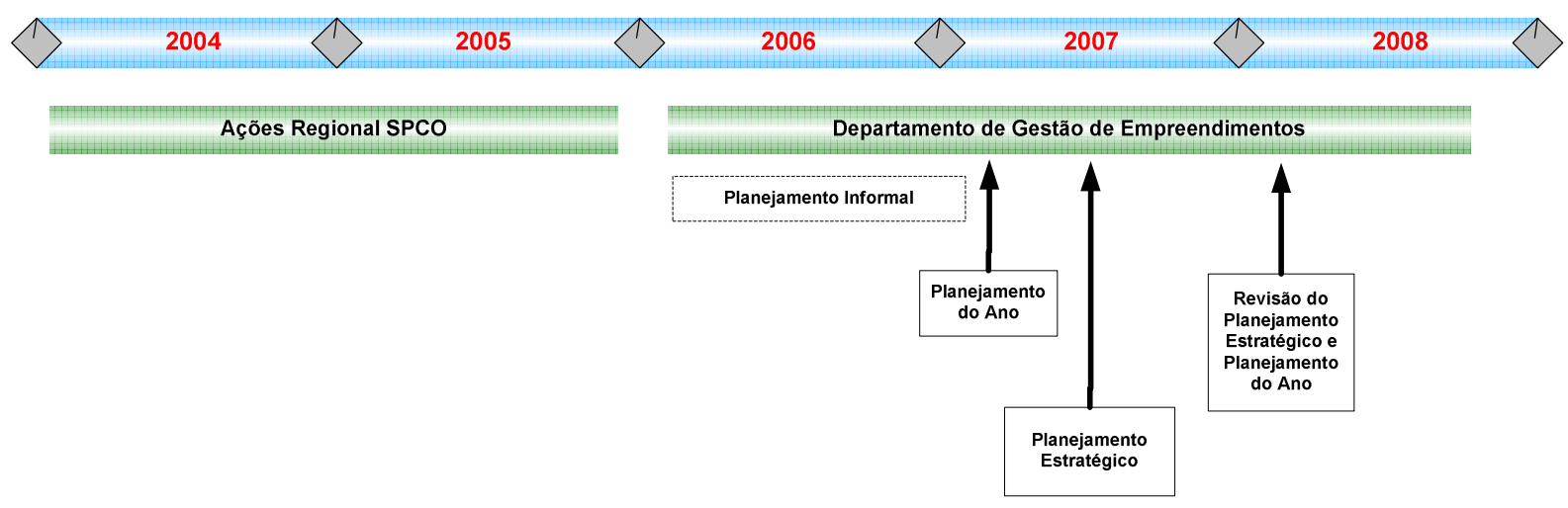

Figura 22: Grandes Movimentos no EGP da LogB

(Fonte: autor)

O início das atividades do EGP da LogB ocorreu no início de 2006 com a criação oficial do departamento chamado "Gestão de Empreendimentos". Entretanto, as ações que possibilitaram a criação deste departamento vinham ocorrendo desde início de 2004, através de ações que a Regional São Paulo e Centro Oeste (SPCO) vinham realizando em prol da gestão de projetos.

A Regional SPCO vivia naquele momento uma série de problemas causados justamente pela falta de aplicação da gestão de projetos nos seus empreendimentos. Com o intuito de buscar melhorar a performance de seus empreendimentos, esta regional começou a aplicar a gestão de projetos nos empreendimentos de sua regional.

As ações praticadas pela Regional SPCO nestes dois anos foram: desenvolvimento de uma metodologia de gestão de projetos; desenvolvimento de um software de gestão de projetos para suportar a metodologia; realização de treinamentos em gestão de projetos; mentoring; buscou promover a integração dos departamentos que atuam com empreendimentos; buscou identificar um responsável único para cada projeto (integrador do empreendimento); buscou disseminar a cultura de planejamento e gestão de projetos; e buscou o apoio da alta e média administração para que a gestão de projetos fosse aplicada de forma mais ampla.

Estas ações promovidas pela Regional SPCO ocorreram basicamente em um de seus departamentos, o relacionado a Empreendimentos. Deste departamento partiram as ações para envolver o restante dos departamentos da regional. Estas 
atividades foram realizadas por uma equipe de 4 pessoas, sendo 3 consultores terceirizados mais o coordenador do departamento.

As ações realizadas pela Regional SPCO coincidem com as idéias propostas por Englund, Graham e Dinsmore (2003) e Crawford (2002). Para estes autores, antes de iniciar a implantação de um EGP, é necessário que se "crie as condições para a mudança", ou seja, que se prepare a base para se poder partir com a decisão por se implantar um EGP. Pode ser considerado que o trabalho completo de se estabelecer estas bases não tenha sido concluído, mas uma parte importante foi realizada, pois o trabalho realizado por esta regional repercutiu em toda a organização, inclusive na alta administração.

Desta repercussão surgiu a definição pela criação do departamento de Gestão de Empreendimentos. Como as coisas na vida real não acontecem de forma linear, este departamento surgiu originalmente de uma necessidade de se melhorar o fluxo de comunicação e reporte dos projetos da base para a média e alta administração. Nesta época, informações importantes dos projetos, como status, relatórios, maiores problemas, previsão de gastos futuros, não chegavam de forma eficiente para os altos níveis gerenciais da organização. O intuito do então criado departamento era aperfeiçoar este fluxo de informação, fazendo com que as informações dos projetos chegassem à média e alta administração.

Entretanto, com a repercussão dos trabalhos realizados pela Regional SPCO, a gerência deste novo departamento decidiu por trazer para sua equipe o coordenador do departamento de Empreendimentos da referida regional. Aproveitando a oportunidade, este coordenador convenceu a gerência do departamento em implantar em nível nacional as mesmas práticas e filosofias que estavam sendo implantadas na Regional SPCO. Dessa forma os resultados esperados pelo novo departamento iriam atender as expectativas originais e ainda superá-las, pois a abrangência das ações seria bem maiores que as originalmente previstas. Estava neste momento nascendo um departamento com todas as características de um EGP. 
É interessante notar que todo este processo que se originou nas ações da Regional SPCO até a criação do departamento de Gestão de Empreendimentos está de acordo com as idéias propostas por Kerzner (2001b) para a fase Embrionária de seu método de avaliação da maturidade em gestão de projetos. Kerzner (2001b) afirma que normalmente os primeiros contatos com a gestão de projetos ocorrem nos níveis inferiores da estrutura organizacional. Engenheiros, coordenadores e supervisores são quem normalmente tem os primeiros contatos com a disciplina e acabam ficando com a responsabilidade (ou pró-atividade) de "vender" esta idéia aos níveis superiores.

Este departamento criado, apesar de originalmente não ter tido a intenção específica de ser um EGP, tem todas as características de um EGP. A caracterização deste departamento como um EGP é obtida pela análise de suas funções, responsabilidades e forma de atuação, as quais estão totalmente de acordo com as definições e conceitos de um EGP, conforme apresentado nos itens 3.1, 3.3.6 e 3.3.7. Nos próximos itens ficará claro que as funções deste departamento, suas responsabilidades, sua forma de atuação, sua intenção de melhorar a gestão de projetos na organização, seu trabalho em promover um processo de mudança de cultura organizacional, sua evolução customizada de tempos em tempos para se adequar à cultura organizacional e até seu posicionamento na estrutura organizacional, estão todos compatíveis com a de um EGP.

Deste modo, este departamento foi implantado e continua funcionando de forma equivalente a um EGP. No próximo item será comentado a respeito do planejamento da implantação deste EGP e em seguida será discutido seu planejamento estratégico.

\subsection{AS FASES DA IMPLANTAÇÃO DO EGP}

Este trabalho foca a realização do planejamento para implantação do EGP da empresa LogB. Para tanto, será considerado neste trabalho o planejamento 
realizado após a criação oficial do departamento Gestão de Empreendimentos, ou seja, a partir do início de 2006, conforme Figura $22^{8}$.

Conforme a Figura 22 novamente, as etapas da implantação deste EGP não seguiram as mesmas etapas propostas por este autor descritas no item 3.2.2 e apresentada na Figura $5^{9}$.

$\mathrm{Na}$ implantação do EGP da LogB não foram criadas fases oficiais de implantação. Inclusive, não se consegue separar um momento onde ocorreram exclusivamente atividades de planejamento, nem no seu início. No início, no decorrer do ano de 2006, as atividades de planejamento e execução das atividades ocorreram em paralelo. Por isto, está sendo considerado que durante o ano de 2006, o planejamento foi informal. Ou seja, ocorreu, mas através de conversas, discussões e reuniões durante todo o ano.

No início de 2007 ocorreu o primeiro planejamento formal do EGP. Entretanto, seu objetivo foi planejar as atividades que ocorreriam em 2007, e não abordou aspectos do planejamento estratégico. O planejamento estratégico deste EGP ocorreu em meados de 2007.

Após isto, no início de 2008, houve uma revisão formal do planejamento estratégico do EGP e um detalhamento do planejamento para o ano de 2008.

Comparado com o método proposto pelo autor (item 3.2.2), o planejamento estratégico do EGP ocorrido em meados de 2007 e início de 2008 podem ser considerados como o planejamento estratégico descrito no item 3.3. E os planejamentos detalhados dos anos 2007 e 2008, podem ser considerados como o planejamento das fases (tático / operacional), descrito no item 3.4.

\footnotetext{
${ }^{8}$ Como apresentado no capítulo 2, as ações realizadas na Regional SPCO não é foco desta dissertação, pois suas ações estão sendo consideradas como as necessárias para que houvesse uma condição viável para se tomar a decisão por criar o EGP. Entretanto, quando pontos relevantes deste período forem importantes para a compreensão do planejamento do EGP, estes serão devidamente tratados e esclarecidos.

9 A implantação do EGP da $\operatorname{LogB}$ não poderia ter seguido o método proposto por este autor uma vez que esta dissertação (e conseqüentemente, esta proposição de forma de implantação) foi escrita em 2008, dois anos após o início das atividades deste EGP. As análises deste estudo visam confrontar os fatores considerados no planejamento do EGP desta empresa com os identificados no capítulo 3.
} 
No item seguinte são analisados como os assuntos relacionados ao planejamento estratégico de um EGP, abordado no item 3.3, foram realizados no EGP da LogB.

\subsection{O PLANEJAMENTO ESTRATÉGICO DO EGP}

Conforme comentado no item anterior, o planejamento estratégico do EGP ocorreu apenas em meados de 2007, um ano e meio após o início de suas atividades e foi revisado no início de 2008. Entretanto, vários dos assuntos que deveriam ser tratados no planejamento estratégico, acabaram sendo discutidos no que foi chamado de "planejamento informal", que ocorreu durante o ano de 2006, de acordo com a Figura 22.

Portanto, as análises realizadas nos próximos itens levam em consideração tanto as decisões tomadas no planejamento estratégico quanto no planejamento informal. Os itens seguintes analisam todos os aspectos da elaboração do planejamento estratégico, conforme apresentado no item 3.3.

\subsubsection{Diagnóstico da Situação Atual}

Conforme exposto no item 3.3.1, Oliveira (2002) e Crawford (2002) deixam claro a importância por se realizar um diagnóstico da atual situação da gestão de projetos na empresa, com o intuito de determinar "onde se está". Dessa forma torna-se possível identificar quais os maiores, principais e mais urgentes problemas que a empresa deve buscar resolver.

Da lista de problemas mais comuns que ocorrem com a gestão de projetos, programas e portfólios nas empresas, apresentado no item 3.3.1, a empresa LogB vivia os problemas apresentados na Tabela 14. A identificação destes problemas ocorreu de maneira informal, durante o período do planejamento informal descrito na Figura 22, e representa o resultado do diagnóstico da situação atual da LogB. 


\begin{tabular}{|l|c|}
\hline Baixa eficiência no controle e execução dos projetos, programas e portfólios; & $\mathrm{X}$ \\
\hline Projetos concluídos acima dos custos e prazos estimados; & $\mathrm{X}$ \\
\hline Projetos concluídos fora da especificação ou sem a qualidade esperada; & $\mathrm{X}$ \\
\hline Excesso de alteraçães de escopo; & $\mathrm{X}$ \\
\hline $\begin{array}{l}\text { Falta de padronização na forma de planejamento, execução e avaliação dos } \\
\text { projetos e consequentemente, da gestão de projetos; }\end{array}$ & $\mathrm{X}$ \\
\hline Má utilização dos recursos dos projetos; & $\mathrm{X}$ \\
\hline Comunicação ineficiente entre os vários stakeholders do projeto e da empresa; & $\mathrm{X}$ \\
\hline Planejamento do projeto realizado de forma ineficiente; & $\mathrm{X}$ \\
\hline Lucratividade abaixo da estimada; & \\
\hline Baixa produtividade dos recursos (materiais e humanos); & \\
\hline Ferramentas de gestão sem padronização; & $\mathrm{X}$ \\
\hline Falta de aderência do projeto com os objetivos estratégicos da empresa; & \\
\hline Falta de priorização dos projetos; & $\mathrm{X}$ \\
\hline Falta de treinamento e capacitação da equipe em gestão de projetos; & $\mathrm{X}$ \\
\hline Cultura organizacional resistente à aplicação da gestão de projetos; & $\mathrm{X}$ \\
\hline Falta de base de dados sobre os projetos da empresa; & $\mathrm{X}$ \\
\hline Falta de uma base de dados do histórico dos projetos da empresa; & $\mathrm{X}$ \\
\hline Falta de documentação e gerenciamento da base de lições aprendidas; & $\mathrm{X}$ \\
\hline Falta de documentação e gerenciamento de uma base de riscos; & $\mathrm{X}$ \\
\hline Má definição das responsabilidades dentro do projeto; & $\mathrm{X}$ \\
\hline Falta de um responsável único pelo projeto; & $\mathrm{X}$ \\
\hline Integração entre as gerências funcionais ineficiente; & $\mathrm{X}$ \\
\hline Necessidade de controlar vários projetos simultaneamente; & $\mathrm{X}$ \\
\hline Necessidade de controlar múltiplos fornecedores simultaneamente; & $\mathrm{X}$ \\
\hline Necessidade de prover relatórios consolidados de vários projetos; & \\
\hline Necessidade de prover uma fonte única de comunicação com os clientes; & \\
\hline
\end{tabular}

Tabela 14: Problemas existentes na $\operatorname{LogB}$

(Fonte: autor)

Como pode ser observado, a LogB vivia a maioria dos tipos de problemas mais comuns. Ainda assim, ocorriam mais alguns problemas específicos desta empresa, sendo eles:

Falta de visão do projeto como um todo. A gestão era normalmente realizada para os "contratos" ao invés de ser para os "projetos" (um projeto pode ter um ou vários contratos); 
$>$ O controle financeiro dos projetos era realizado sobre a previsão de gasto anual ao invés do valor total do projeto (pluri-anual), também prejudicando a visão do projeto como um todo;

$>$ Dificuldade de obtenção de dados de custos realizados dos projetos;

> Problemas oriundos da utilização de uma estrutura organizacional funcional para a condução dos projetos, conforme apresentado no item 3.3.7.1.

Pelo tipo e quantidade de problemas identificados, fica evidente a necessidade de implantação de um EGP para buscar melhorar esta situação.

A situação real da LogB se mostrou condizente com o exposto no item 3.3.1. Alguns problemas específicos de uma determinada empresa devem ocorrer, mas os problemas mais comuns estão presentes nos problemas listados no item 3.3.1.

\subsubsection{Benefícios Esperados}

Conforme discutido no item 3.3.2, não há como se padronizar os benefícios que um EGP pode ou deve fornecer à sua organização. Estes benefícios estão relacionados às funções atribuídas ao EGP.

Deste modo, os benefícios esperados para a LogB com a implantação do EGP estão relacionados com sua capacidade de resolver os problemas identificados em seu diagnóstico atual (item 4.4.1).

Como será visto no item 4.4 .5 (Funções do EGP), o EGP da LogB recebeu a responsabilidade de buscar melhorar todos os itens listados no diagnóstico atual (item 4.4.1), com exceção dos relacionados à gestão do portfólio.

Um ponto de melhoria na implantação do EGP da LogB, é que estes problemas e seus respectivos benefícios não estava documentados e também não foram priorizados. Ou seja, não há um documento indicando quais serão os problemas que serão tratados no curto prazo e quais serão tratados no longo prazo. Consequentemente, os stakeholders envolvidos, principalmente os da alta e média 
administração, não estavam cientes de quais benefícios deviam esperar no curto e no longo prazo. Essa situação gerou no decorrer da implantação, um sentimento de frustração nos stakeholders, aumentando os níveis de resistência contra a implantação do EGP.

É interessante notar também a coerência das idéias apresentadas por Gonzáles e Rodrigues (2002) no item 3.3.2 (Figura 6), quanto ao valor que um EGP pode retornar à organização dependendo das funções assumidas. As funções assumidas pela EGP da LogB estão mais relacionadas à capacitação e aperfeiçoamento das atividades operacionais, através de funções como treinamento, suporte aos gerentes de projetos, desenvolvimento de metodologia e ferramentas. Dessa forma, o foco é maior na melhoria da execução dos projetos.

Outra idéia que se mostra coerente é a apresentada por Block e Frame (1998), que dizem que o EGP gera valor também para os clientes da organização (item 3.3.2). No caso da LogB, pode-se entender que os clientes do EGP sejam as Unidades Operacionais (elas são apresentadas no item da estrutura organizacional - item 4.4.6.1). As Unidades Operacionais foram as áreas que mais demonstraram apoio à implantação do EGP e às suas práticas e políticas. Foi onde ocorreu o menor nível de resistência à implantação. Este fato pode se explicar porque os maiores beneficiários pela melhor condução dos projetos da organização seriam eles, pois eles são os "donos" do dinheiro e responsáveis pela operação dos empreendimentos.

Assim, a situação real da LogB se mostrou condizente com o exposto no item 3.3.2. Os benefícios esperados pela companhia estão relacionados com as funções designadas ao EGP para resolver os problemas de projetos da organização.

\subsubsection{Condições de Viabilidade para Implantação}

No item 3.3.3, Dinsmore (2002) associa a implantação de um EGP a um processo de mudança de cultura organizacional, para o qual seriam necessários dois fatores para que pudesse ocorrer: pressão externa e insatisfação interna suficientes. 
No caso da LogB, não havia pressão externa, pois o mercado na qual atua estava em expansão e o preço do produto tinha registrado elevados aumentos nos últimos anos. A empresa tinha uma situação financeira equilibrada e não estava passando por nenhuma crise ou pressão externa que a obrigasse a mudar seu modo de trabalho. Ou seja, por este critério, a empresa não estava em um ambiente favorável para a implantação de um EGP.

Do mesmo modo, não existia na $\operatorname{LogB}$ uma insatisfação geral entre seus funcionários que provocasse uma necessidade urgente por mudar sua cultura ou forma de trabalho. Existia uma certa convicção da necessidade de melhorar a forma de realizar a gestão de seus projetos, mas não havia um movimento forte e claro buscando mudar esta situação. Ou seja, por este critério a empresa também não estava em um ambiente favorável para a implantação de um EGP.

Outro ponto comentado no item 3.3.3, é a necessidade de verificação se existe uma massa crítica de pessoas com conhecimento em gestão de projetos na organização (Toledo; Rovai, 2002). Na LogB não havia essa massa crítica. Havia poucas pessoas na organização com conhecimento em gestão de projetos. Esta falta de massa crítica aumentou significativamente as resistências à implantação do EGP por parte de seus funcionários, o que está de acordo com a idéia apresentada no item 3.3.3.

Portanto, os fatores acima apresentados sugeriam que não havia uma condição viável para a implantação do EGP na LogB. Entretanto, a implantação foi conduzida e atualmente o EGP está funcionando. Porém, sua implantação ocorreu em um ambiente com muita resistência por parte dos funcionários da $\log B$, o que poderia ter sido menor caso estes fatores indicassem uma situação mais viável para implantação.

Como conclusão, as análises apresentadas no item 3.3.3 se mostraram aplicáveis ao caso da LogB, com uma pequena ressalva para uma idéia de Dinsmore (2002). Segundo este autor, caso não houvesse pressão externa e insatisfação interna, não seria possível implantar um EGP. Este caso da LogB mostrou que é possível 
implantar um EGP mesmo sem estas duas condições, porém, com um aumento significativo dos níveis de resistência, o que pode gerar também um aumento sensível do risco de fracasso da implantação. Este raciocínio está coerente também com Kerzner (2001b), que diz que mudanças no estilo de gerenciamento e na cultura organizacional ocorridas durante épocas economicamente favoráveis ocorrem de maneira lenta.

As demais questões apresentadas no item 3.3.3 também se mostraram aplicáveis ao caso. A criação de uma massa crítica de pessoas com conhecimento em gestão de projetos é importante para minimizar a resistência das pessoas, conforme lembrado por Toledo e Rovai (2002). Caso ela não exista, há a necessidade de se concentrar as ações de curto prazo na capacitação e treinamento de seus funcionários, o que foi uma medida tomada pelo EGP da LogB.

\subsubsection{Objetivos Estratégicos}

No item 3.3.4, Costa (2006) e Oliveira (2002) deixam claro a necessidade de se construir os alicerces de sustentação do EGP caracterizando os itens apresentados na Figura 7.

A visão e missão do EGP da LogB foram definidas no planejamento estratégico de meados de 2007 e alteradas na revisão do planejamento estratégico que ocorreu no início de 2008, resultando em:

Visão: "Ser reconhecida como referência em gestão de empreendimentos".

Missão: "Promover a gestão de empreendimentos na LogB de forma segura, rentável e integrada, com responsabilidade social e ambiental".

O conteúdo da visão e missão da LogB está de acordo com os conceitos apresentados por Costa (2006) e Oliveira (2002). A visão está indicando onde a empresa quer chegar e a missão está indicando como ela vai chegar lá. 
Os princípios e os valores do EGP da LogB não foram definidos, pois, de uma maneira informal, o senso comum da equipe do EGP adotou os princípios e os valores da própria organização como um todo.

Um importante processo que foi discutido apenas de forma parcial foi a abrangência de atuação do EGP da LogB. A abrangência de atuação limitaria os pontos de atuação do EGP, dando foco às ações prioritárias. Poderia, por exemplo, limitar o tipo, o porte ou a divisão da empresa que receberia os serviços do EGP. No planejamento estratégico de meados de 2007 e na revisão do início de 2008 chegou-se a discutir esse assunto. Sobre o porte dos projetos, foi definido que 0 EGP atuaria nos projetos de grande e médio porte, com serviços de consultoria, mentoring, treinamento e também fazendo a gestão destes projetos quando fosse de comum acordo com todos stakeholders envolvidos. E para os projetos de pequeno porte, atuaria com consultoria, mentoring e treinamento, mas não iria fazer a gestão dos projetos.

Sobre o tipo de projetos, a equipe do EGP não definiu em qual tipo atuaria, ou seja, deixou em aberto a chance de atuar em todos. $E$ quanto às divisões da empresa onde o EGP atuaria, a equipe do EGP também não limitou nem priorizou nenhum departamento.

Entretanto, a abrangência de atuação deveria ter sido definida de forma mais precisa. Conforme apresentado no item 4.1, a empresa tem mais de 2500 projetos na sua carteira, o que inviabiliza sua participação em todos eles. Portanto, seria fundamental delimitar claramente quais seriam os projetos no qual o EGP atuaria, para que o mesmo direcionasse seus esforços e também para permitir uma melhor avaliação dos resultados gerados.

Outro ponto não discutido no planejamento estratégico do EGP da LogB foi o direcionamento estratégico. Conforme comentado no item 4.4.2, os problemas identificados no diagnóstico atual da empresa (item 4.4.1) não foram documentados nem priorizados. Isto era importante que tivesse sido feito para indicar os problemas de maior gravidade a serem enfrentados, dando foco às ações do EGP. 
As análises dos fatores externos e internos foram realizadas no planejamento estratégico de meados de 2007 e foram revisadas no planejamento estratégico do início de 2008. Em ambos foram analisados as oportunidades, ameaças, pontos fortes e pontos fracos do EGP da LogB. Os fatores externos foram analisados sob um ponto de vista externo ao EGP, mas ainda dentro da organização. Por uma questão de confidencialidade, os resultados destas análises não são apresentados nesta dissertação.

A análise dos stakeholders foi realizada, porém, durante a fase do planejamento informal (Figura 22). Esta análise foi documentada e mostrava os principais stakeholders com os quais a equipe do EGP teria relacionamento. Uma extensão deste trabalho poderia ter sido realizada com o objetivo de identificar os grupos que poderiam gerar maior resistência às ações do EGP e também os possíveis aliados. Para estes, deveriam ser criadas ações específicas para minimizar ou maximizar seus impactos. Dessa forma, poderia ter sido evitado alguns focos de resistência que ocorreram na implantação do EGP.

Após as análises realizadas, o próximo passo realizado foi a definição dos objetivos estratégicos, tomando-se o cuidado para garantir o seu alinhamento com os objetivos da empresa. Este alinhamento foi validado verificando-se que 0 planejamento estratégico da LogB apontava ações no sentido de aprimorar a gestão de empreendimentos na organização.

Os objetivos e as estratégias do EGP foram definidos no planejamento estratégico realizado em meados de 2007 e foram revisados no planejamento estratégico do início de 2008. Eles geraram 11 estratégias, que por questão de confidencialidade não serão apresentados nesta dissertação.

Entretanto, estes objetivos e estratégias não foram distribuídas no tempo, ou seja, não foram definidas as fases de curto, médio e longo prazo. Este fato acarretou em uma situação onde as 11 estratégias deveriam ser executadas já de imediato, não definindo desta forma os focos de atuação do EGP. Este problema foi minimizado com a revisão do planejamento estratégico do início de 2008, o qual definiu as ações 
a serem realizadas em 2008, mas não indicou as ações e focos para o médio e longo prazo.

Um cuidado que não ocorreu no planejamento estratégico de meados de 2007 foi a aplicação da técnica chamada Seqüência W, conforme apresentado por Costa (2006) e Oliveira (2002). A falta de aplicação desta técnica gerou a determinação de algumas estratégias que dificilmente seriam viabilizadas devido a realidade operacional ser diferente da imaginada quando elaborada a estratégia. Este problema já não ocorreu na revisão do planejamento estratégico do início de 2008 , onde se aplicou a Seqüência W. Nesta versão, as estratégias foram analisadas e validadas pelo nível operacional, o que alinhou as expectativas dos níveis gerenciais e operacionais do departamento.

Como conclusão, as análises apresentadas no item 3.3.4 se mostraram aplicáveis à situação real da $\operatorname{LogB}$. Caso todas as recomendações tivessem sido implantadas, poderiam ter sido evitados problemas na implantação do EGP. O ponto mais relevante identificado é que o planejamento estratégico do EGP deveria ter sido realizado no início de 2006, ou seja, antes de iniciar a implantação do EGP. Desse modo, o EGP teria mais foco em suas ações, podendo gerar valor à organização de forma mais rápida. Outro ponto relevante seria o aprofundamento da discussão da abrangência de atuação do EGP, com a limitação dos projetos que seriam atendidos pelo EGP. O direcionamento estratégico também poderia ter ajudado a indicar os pontos focais da implantação. Outro ponto importante seria a distribuição dos objetivos e estratégias do EGP ao longo do tempo, definindo as fases de curto, médio e longo prazo, conforme é ressaltado também por Crawford (2002). E é importante ressaltar a importância da aplicação da técnica Seqüência W.

Desse modo, confirma-se a coerência dos fundamentos teóricos apresentados no item 3.3.4. No próximo item são discutidas as funções designadas ao EGP desta empresa. 


\subsubsection{As Funções do EGP}

Conforme apresentado no item 3.3.6, as funções atribuídas a um EGP devem estar relacionadas com os problemas de gestão de projetos, programas e portfólios que necessitam serem solucionados na empresa.

No caso da LogB, as funções designadas ao EGP estão relacionadas com os problemas identificados no item 4.4.1. Como já comentado no item 4.4.2, o EGP da LogB ficou com a responsabilidade de buscar melhorar todos os itens listados no diagnóstico atual (item 4.4.1), com exceção dos relacionados à gestão do portfólio.

Para facilitar os trabalhos, a equipe do EGP adotou o agrupamento de funções sugerido por Rad e Raghavan (2000), incluindo um terceiro grupo chamado de Tecnologia. Assim, as funções designadas foram:

\section{Processos}

- Desenvolver e implementar uma metodologia de gestão de projetos;

- Promover projetos pilotos para aplicação da metodologia;

- Promover a integração entre áreas e departamentos;

- Avaliar a maturidade em gerenciamento de projetos.

- Reportar status e evolução dos projetos para todos os interessados;

- Fazer o acompanhamento e controle dos projetos prioritários;

- Desenvolver e manter um painel de controle dos projetos;

- Desenvolver a base de dados sobre os projetos;

- Implementar e gerenciar a base das lições aprendidas;

- Implementar e gerenciar a base dos riscos;

- Realizar benchmarking em gestão de projetos.

$>$ Pessoas

- Desenvolver a competência das pessoas, incluindo treinamento em:

- Gestão de projetos;

- Padrões e metodologias desenvolvidas;

- Software de gestão de projetos desenvolvido;

- Planejamento e controle de projetos;

- Oferecer consultoria e assistência nos projetos; 
- Prover aconselhamento (mentoring);

- Realizar palestras de sensibilização para alta e média administração;

- Promover a gestão de projetos dentro da organização;

- Promover a mudança de cultura na organização;

- Promover a cultura pelo foco no planejamento do projeto.

\section{Tecnologia}

- Desenvolver, implantar e operar softwares customizados de gerenciamento de projetos;

- Selecionar, implementar, assistir e manter softwares de gerenciamento de projetos.

Outras funções atribuídas ao EGP mas que não se encaixam nestas três divisões são: fazer a gestão de projetos de empreendimentos de grande e médio porte financeiro; oferecer suporte de planejamento; monitorar e controlar o desempenho do próprio EGP.

Com o intuito de avaliar o agrupamento de funções propostos pelo autor no item 3.3.6, as mesmas funções do EGP da LogB são apresentadas na Tabela 15, de acordo com o agrupamento sugerido pelo autor.

\begin{tabular}{|l|l|c|}
\multicolumn{1}{|c|}{ Grupos de Funções } & $\begin{array}{c}\text { Designado ao EGP } \\
\text { da LogB }\end{array}$ \\
\hline \multirow{4}{*}{1} & Gerenciamento Estratégico & \\
\cline { 2 - 3 } & Prover conselhos para gerência superior; & \\
\cline { 2 - 3 } & Participar do planejamento estratégico; & \\
\cline { 2 - 3 } & Participação ativa nas estratégias corporativas; & $\mathrm{X}$ \\
\cline { 2 - 3 } & Desenvolvimento da integração entre áreas e departamentos; & $\mathrm{X}$ \\
\cline { 2 - 3 } & Gerenciamento dos benefícios; & \\
\cline { 2 - 3 } & Benchmarking. & \\
\hline
\end{tabular}

Tabela 15: Funções atribuídas ao EGP da $\operatorname{LogB}$ (continua)

(Fonte: autor) 
Grupos de Funções

Designado ao EGP da $\operatorname{LogB}$

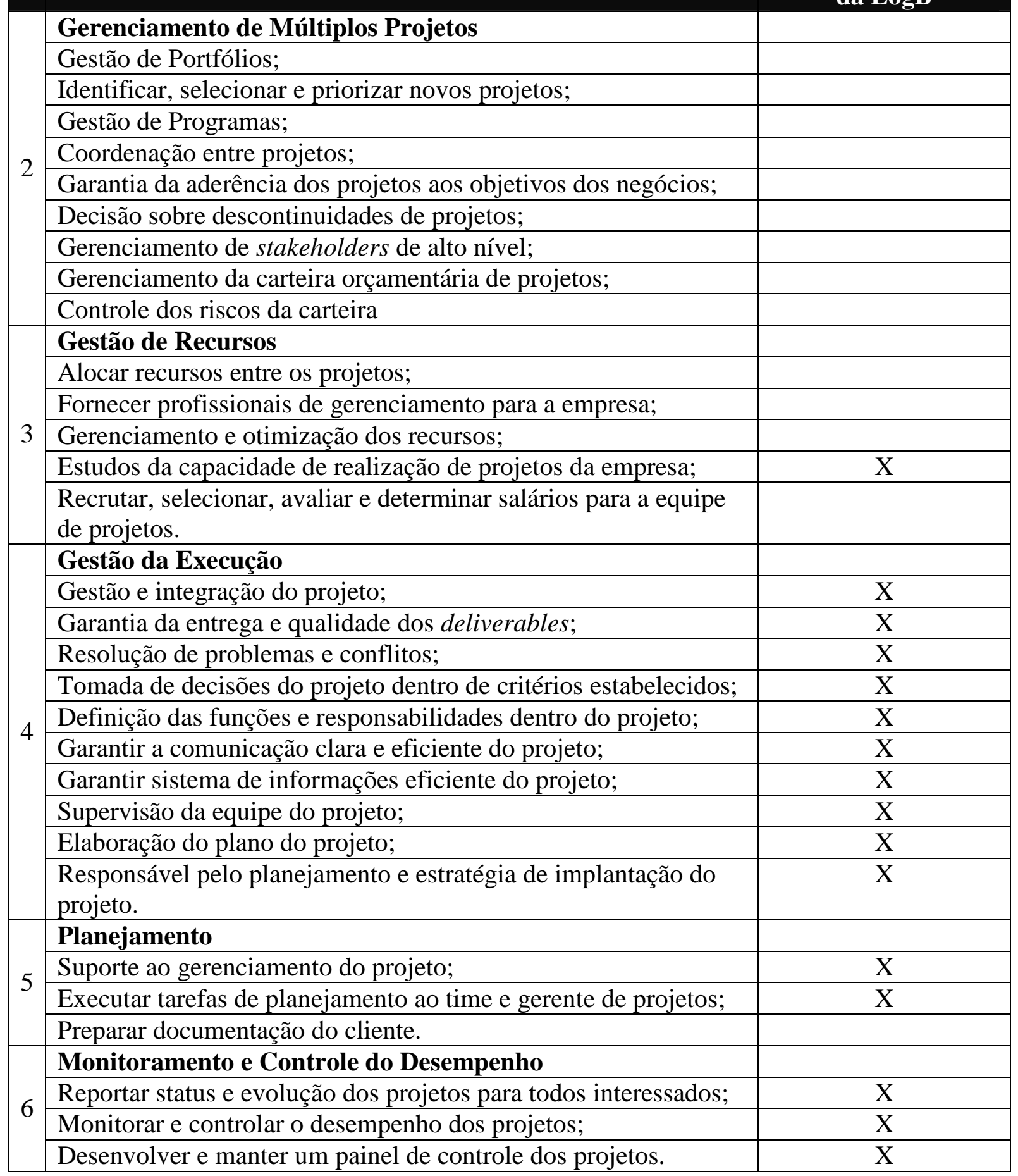

Tabela 15: Funções atribuídas ao EGP da LogB (continuação)

(Fonte: autor) 


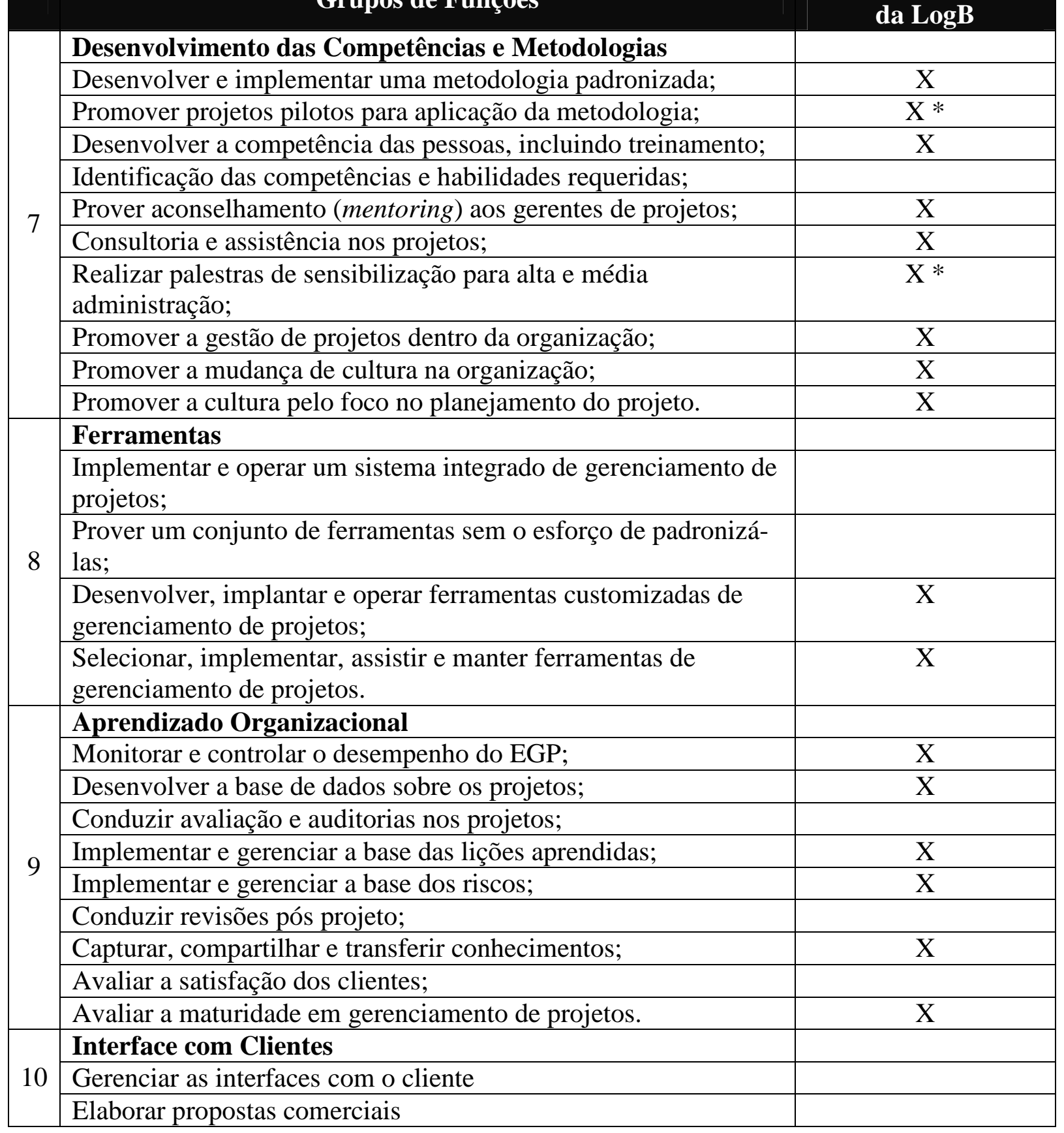

Tabela 15: Funções atribuídas ao EGP da $\operatorname{LogB}$ (continuação)

(Fonte: autor)

Obs. 1: o símbolo " * " indicado em algumas linhas desta tabela indica que a função é adicional ao inicialmente proposto no item 3.3.6.

Obs. 2: a Gestão da Execução (grupo 4) e o Planejamento (grupo 5) são aplicáveis à parte dos projetos, ou seja, aqueles que forem definidos que ficariam sob a 
responsabilidade do EGP. No caso da Gestão da Execução, o foco seria gerenciar projetos de grande e médio porte financeiro.

Como conclusão, as análises apresentadas no item 3.3.6 também se mostraram aplicáveis à situação real da $\operatorname{LogB}$. As funções descritas no item 3.3.6 e o agrupamento proposto pelo autor na Tabela 8 se mostraram coerentes quando aplicadas no EGP da LogB, compreendendo a maioria de suas funções. Fica clara a vantagem de utilização desta forma de agrupamento por deixar mais evidente as funções normalmente atribuídas a um EGP.

\subsubsection{A Estrutura Organizacional}

Conforme apresentado por Verzuh (2005), um EGP é formado da união de suas funções com a autoridade a ele designada. Esta autoridade é relacionada com o posicionamento que o EGP tem dentro da estrutura organizacional da empresa. Nos próximos itens são apresentados o organograma da empresa e do EGP e o como e o porquê o EGP está posicionado na estrutura organizacional.

\subsubsection{O Organograma da $\operatorname{LogB}$}

A Figura 23 ilustra a estrutura organizacional da LogB. Ela é dividida nas Unidades de Negócio (UN), que representam as atividades fins da organização; da Administração Corporativa, que presta serviços administrativos como Financeiro, Contabilidade, Recursos Humanos, Tecnologia da Informação e Planejamento Corporativo; e da área de Serviços \& Engenharia, responsável pela engenharia, aquisições e implantação dos projetos. 


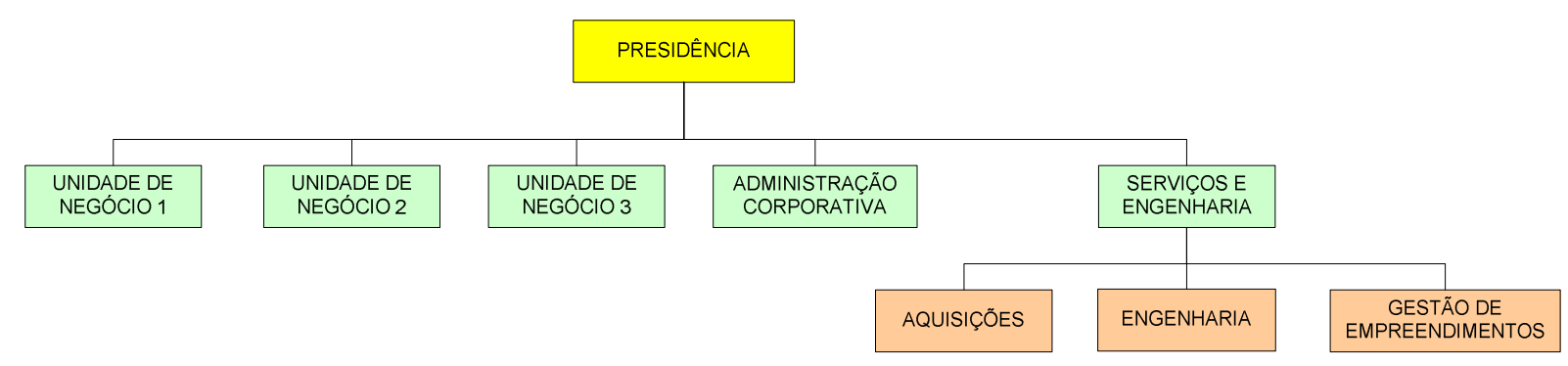

Figura 23: Estrutura Organizacional da LogB

(Fonte: autor)

Conforme já comentado, devido ao porte desta empresa, sua estrutura é subdividida em quatro regionais: SPCO, Sul, SE e NNE. A Figura 24 indica as divisões pelas quatro regionais das Unidades de Negócios:

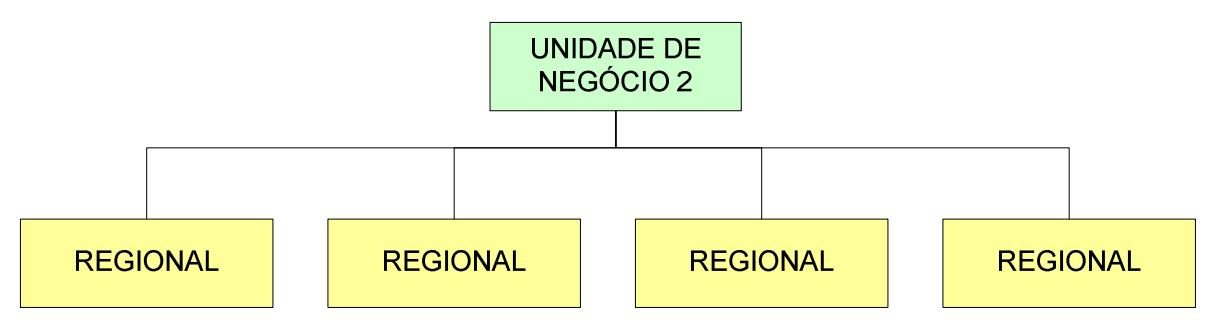

Figura 24: Divisão da Estrutura Organizacional da UN em Regionais (Fonte: autor)

A Figura 25 indica as divisões em áreas e regionais do departamento de Engenharia. A área de Engenharia é responsável pelas funções de Integridade, Projetos e Orçamentos e pelo Suporte Técnico. Este Suporte Técnico é a área responsável pela implantação dos projetos, sendo dividida em quatro regionais e estas divididas em quatro áreas: Empreendimentos, responsável pelos projetos de engenharia e licitações; Obras, responsável pela execução e fiscalização dos projetos; Automação, responsável pela automação dos equipamentos; e Inspeção, responsável pela inspeção e manutenção da qualidade dos equipamentos instalados. 


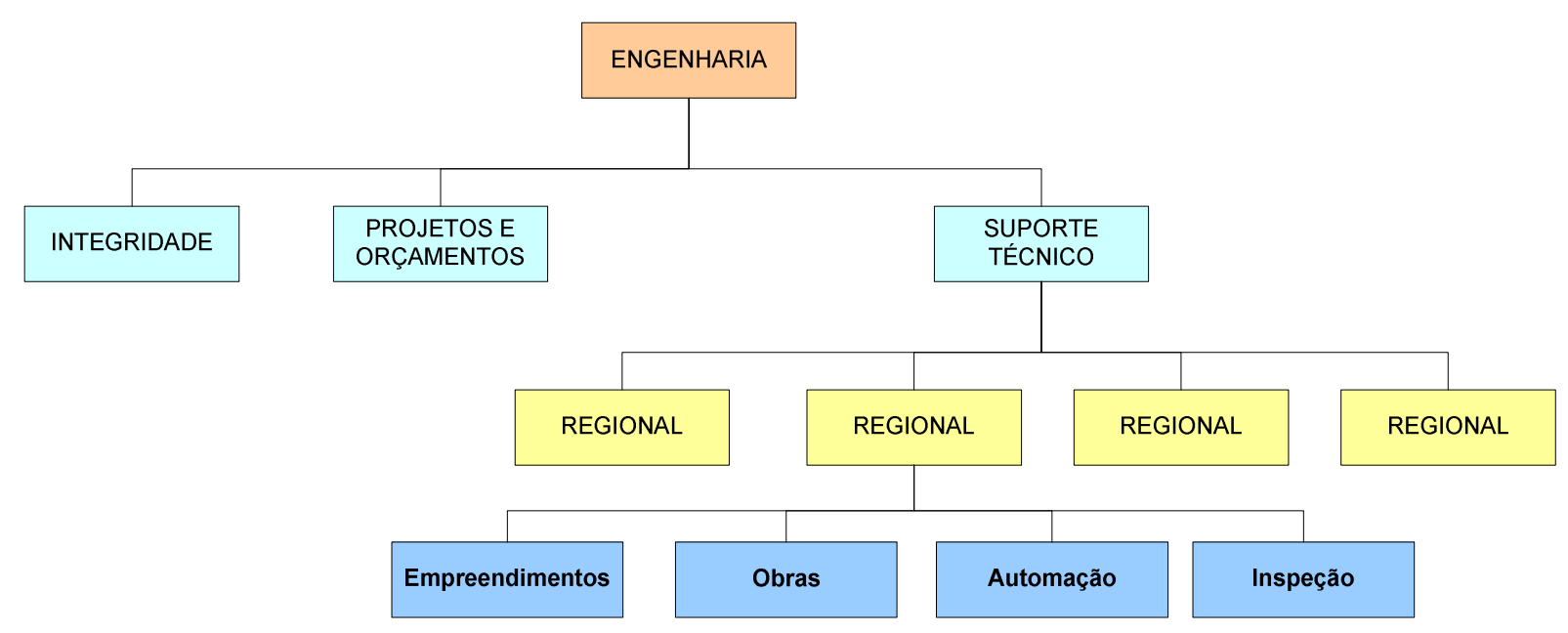

Figura 25: Estrutura Organizacional da Engenharia

(Fonte: autor)

A estrutura organizacional da LogB é do tipo Funcional. Esta conclusão é obtida da análise de como os projetos são conduzidos na empresa. A demanda ou necessidade do projeto é gerada pelas Unidades de Negócios (UN). Esta demanda é enviada a uma sub-área do Suporte Técnico (caixas azuis da Figura 25), onde o serviço referente a esta sub-área é realizado e, quando termina, o serviço é encaminhado à próxima sub-área, e assim por diante. Ou seja, não há uma área que conduza o processo como um todo. Esse processo é ilustrado através da Figura 26.

Esta comprovação também é obtida pela análise das características apresentadas na Tabela 9. Na estrutura da LogB não há gerentes de projetos, portanto, toda a autoridade do projeto está na gerência funcional. O controle da disponibilidade dos recursos e do orçamento é todo da gerência funcional. E a equipe do projeto é sempre alocada no projeto com tempo parcial.

De acordo com o levantamento das desvantagens das estruturas funcionais identificadas por Patah (2004) no item 3.3.7.1, foram identificados os seguintes problemas de gestão de projetos na LogB:

> A responsabilidade total do projeto não era delegada a nenhum funcionário específico. Não havia gerentes de projetos;

A estrutura funcional não facilitava uma abordagem global do projeto; 
$>$ A coordenação tornava-se complexa e era necessário um tempo de espera adicional para aprovação das decisões;

$>$ O departamento funcional tendia a ser orientado às suas atividades particulares;

$>$ As decisões normalmente eram tomadas em favor dos grupos funcionais mais fortes;

Não havia foco nos clientes;

$>$ As respostas às necessidades dos clientes eram lentas;

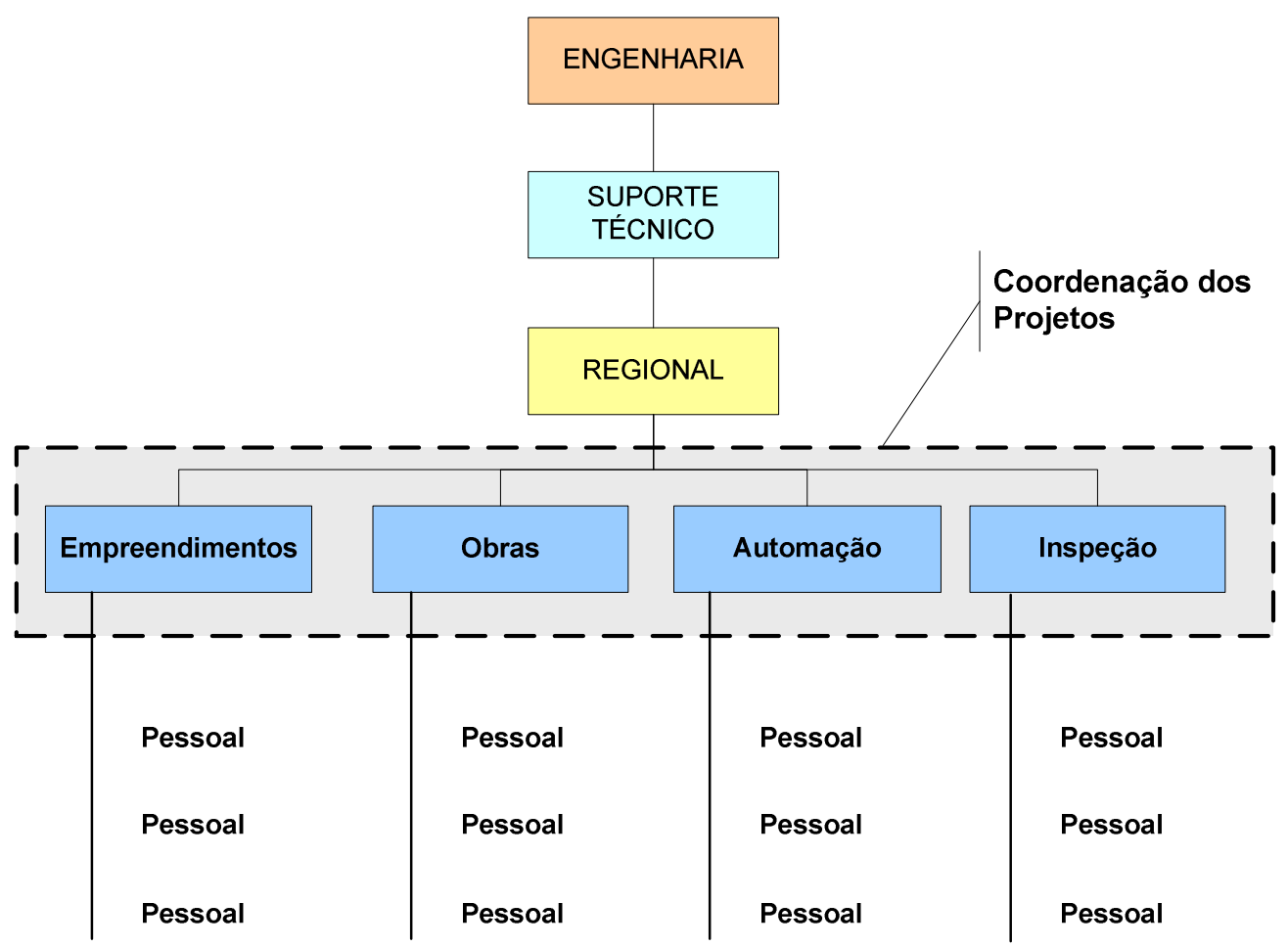

Figura 26: Coordenação dos Projetos via Estrutura Funcional (Fonte: autor)

Estes problemas contribuíram de maneira significativa para os baixos índices de desempenho dos projetos da LogB.

No item seguinte é apresentado o organograma do EGP da LogB. 


\subsubsection{O Organograma do EGP}

A estrutura organizacional definida para o EGP da LogB é representada na Figura 27.

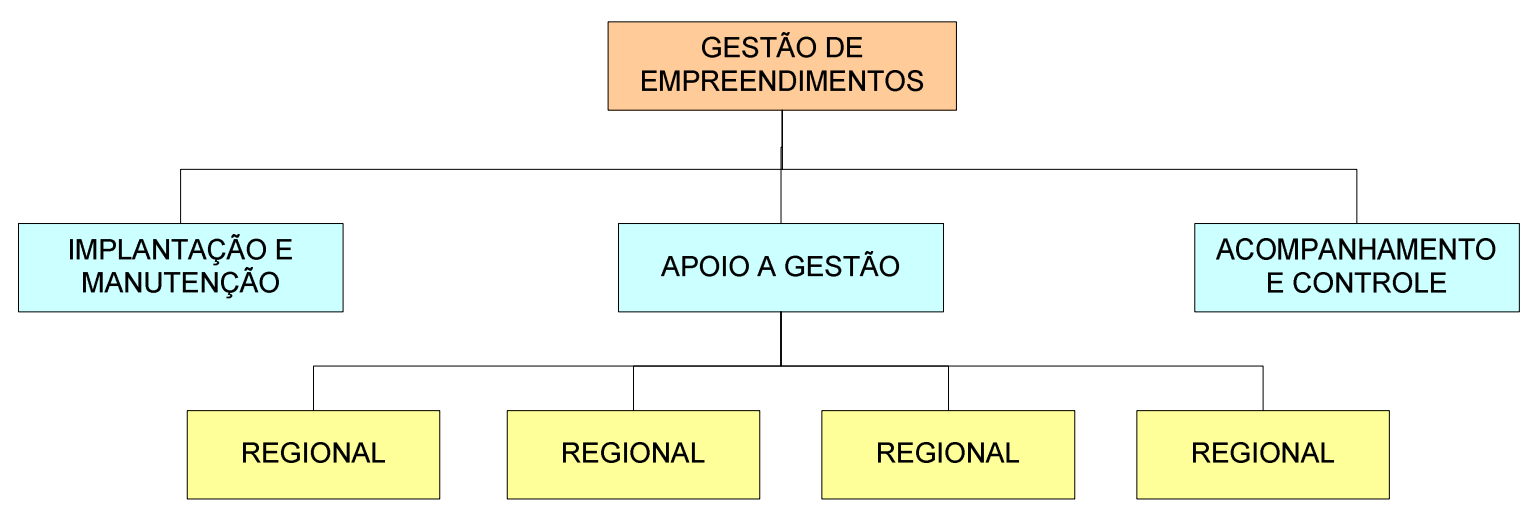

Figura 27: Estrutura Organizacional do EGP da LogB (Fonte: autor)

As funções designadas ao EGP foram divididas em três gerências, conforme abaixo:

> Implantação e Manutenção - responsável pela definição e desenvolvimento das metodologias, ferramentas e treinamentos necessários para a implantação das melhores práticas de gestão de projetos. É também responsável pelo desenvolvimento da base de dados dos projetos, das lições aprendidas e dos riscos, além de avaliar a maturidade em gestão de projetos da organização e realizar benchmarking. É ainda responsável pelo plano de implantação, analisando e avaliando as atividades necessárias para o atingimento dos objetivos propostos pelo EGP. A sua estrutura fica alocada na Sede da empresa.

Apoio à Gestão - responsável pela aplicação das metodologias e ferramentas de gestão de projetos junto às áreas da Engenharia e Unidades de Negócio. É o grupo responsável por manter o contato com os clientes do EGP, buscando promover a mudança de cultura em direção à gestão de projetos, promover a integração entre as áreas e fornecer serviços de consultoria e mentoring. Devido ao porte da empresa e o número de pessoas que é necessário contactar, optouse por dividir a estrutura deste departamento nos mesmos moldes que as demais 
áreas da empresa, dividindo-o em regionais. Assim, a gerência do departamento ficou na Sede da empresa, mas foram criadas Coordenadorias nas quatro regionais (SPCO, SUL, SE, NNE), o que equivale aos EGP Regionais.

Acompanhamento e Controle - responsável pelo acompanhamento e controle dos empreendimentos considerados prioritários pela organização. Para estes, o EGP é responsável por elaborar e atualizar o cronograma, acompanhar a evolução financeira e emitir relatórios de progresso. A estrutura fica alocada na Sede da empresa e utiliza o apoio dos profissionais alocados nas regionais do departamento "Apoio à Gestão".

No item seguinte é analisado como e porque o EGP foi posicionado na estrutura organizacional.

\subsubsection{O Posicionamento do EGP na Estrutura Organizacional}

Conforme ilustrado na Figura 23, o EGP foi posicionado em uma posição relativamente alta da estrutura organizacional. $O$ processo para estabelecimento desta posição para o EGP não ocorreu sob as bases dos fundamentos teóricos apresentados nesta dissertação, mas sobre critérios da alta administração no qual o autor não teve acesso. Ainda assim, é realizada uma análise crítica de seu posicionamento para avaliar os impactos que este teve na sua implantação e operação.

Segundo os fundamentos teóricos apresentados no item 3.3.7.5, os três fatores que devem ser considerados para a definição do posicionamento do EGP na estrutura organizacional são: necessidade de haver um ou mais EGP; os gerentes de projetos estarem ou não dentro do EGP; a associação entre as funções com o nível de autoridade desejado para o EGP.

Litke (1995) apud Patah (2004) alerta que dependendo do tamanho da empresa, há a necessidade de se constituir mais de um EGP para evitar problemas de comunicação com seus membros. Block e Frame (1998) também lembram da 
influência da dispersão geográfica da empresa. Quanto maior a dispersão geográfica, maior a necessidade de haver mais do que um EGP.

No EGP da LogB, as duas situações acima descritas acontecem: a empresa é de grande porte, com uma grande quantidade de pessoas envolvidas; e há uma grande dispersão geográfica, com escritórios estabelecidos em vários pontos do país.

Dessa forma, é coerente a decisão da equipe do EGP em estabelecer um EGP central, de alto nível hierárquico, e estabelecer escritórios regionais ligados a este EGP central. O EGP central tem a responsabilidade pela definição das metodologias, ferramentas e a criação das orientações corporativas. Os EGP regionais servem como uma forma de multiplicar as idéias e atividades do EGP para todos os escritórios da empresa no país, bem como manter contato direto com os usuários que conduzem os projetos.

Outro fator a ser analisado é se os gerentes de projetos da empresa ficarão ou não alocados na estrutura do EGP. Um primeiro questionamento que surge é se a empresa tem ou não atualmente a figura do gerente de projetos ou se há planos para sua criação no futuro.

No caso da $\log B$, quando o EGP foi criado, não havia oficialmente a figura do gerente de projetos, portanto, o posicionamento no EGP na estrutura organizacional não sofreu impacto deste fator.

Porém, no decorrer da implantação do EGP, sua gerência resolveu iniciar o processo de assumir a gestão dos projetos e a alocar gerentes de projetos dentro de seu departamento. São analisadas a seguir as conseqüências desta decisão.

Relembrando as discussões apresentadas no item 3.3.7.5.1, o posicionamento do EGP na estrutura organizacional pode alterar o tipo da estrutura organizacional da organização. Dependendo de onde for colocada, a estrutura de gestão de projetos pode ser funcional, matricial ou projetizada, variando a combinação de poderes entre os gerentes funcionais e os gerentes de projetos. 
No caso da LogB, o EGP foi colocado em uma posição de que permitiria a alteração da estrutura organizacional do tipo funcional para o tipo matricial forte, conforme pode ser verificado na Figura 28. A confirmação que a estrutura organizacional da Figura 28 é equivalente a uma estrutura matricial forte é obtida comparando-a com a estrutura organizacional apresentada na Figura 12. A caixa "Gestão da Execução", seria a responsável pela gestão dos empreendimentos e seria o local onde estariam alocados os gerentes de projetos (Gestor). Ou seja, um gerente de projetos alocado em uma estrutura organizacional deste tipo poderia até chegar a ter um poder sobre os projetos maior do que os gerentes funcionais, devido à sua maior proximidade aos níveis hierárquicos mais altos da organização.

Entretanto, concluir que esta estrutura organizacional é do tipo matricial forte apenas pela análise da Figura 12 levará a um erro se for considerada às características reais que a empresa pretende dar aos seus gerentes de projetos. Para uma análise mais completa, é necessário também analisar as características contidas na Tabela 9, o que se levará a conclusão que na prática, a estrutura possível de ser implantada, levará a uma estruturação organizacional do tipo matricial balanceada. Os motivos que levam a esta conclusão são:

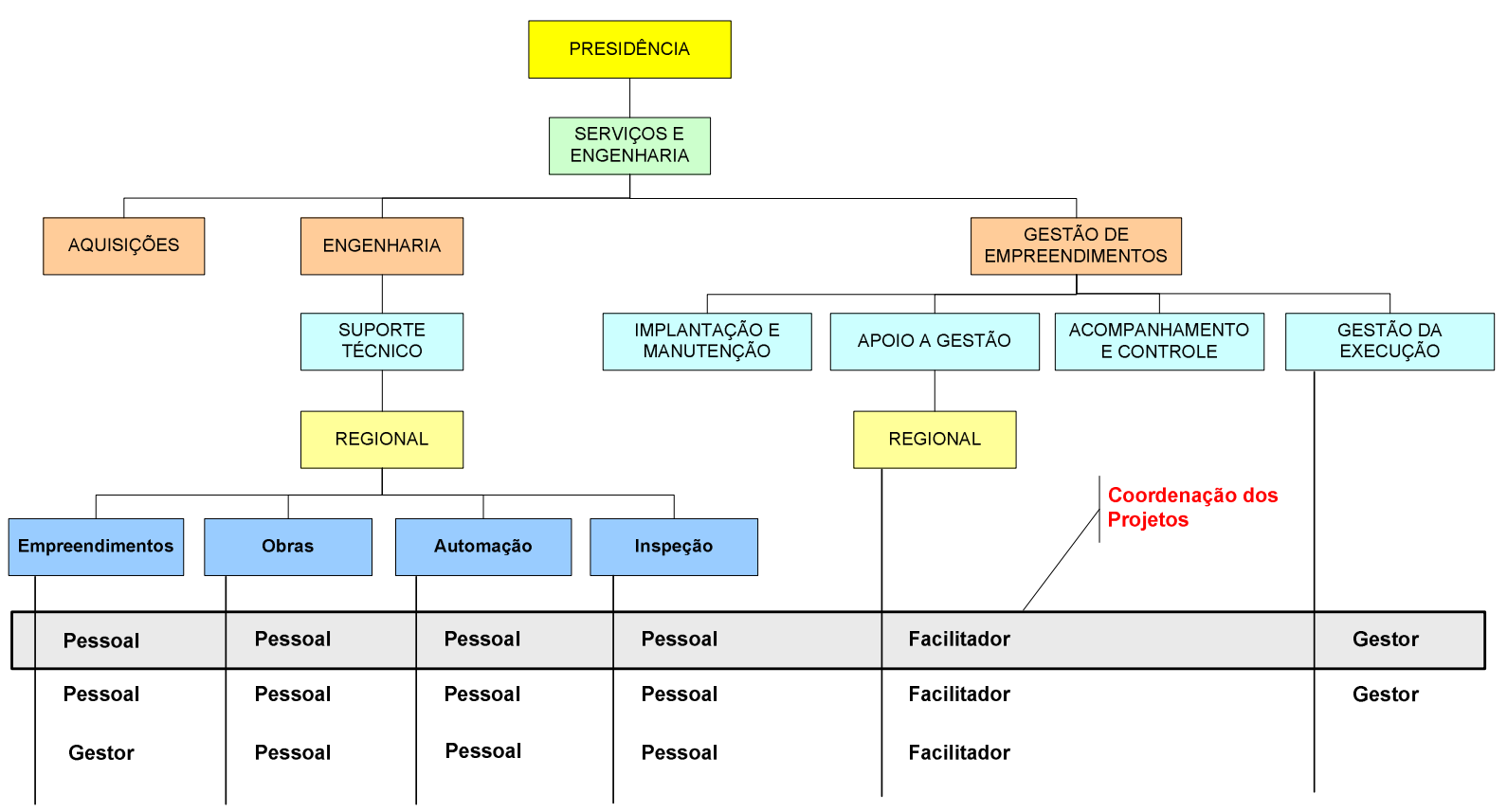

Figura 28: Alteração da Estrutura Organizacional para o Tipo Matricial Forte (Fonte: autor) 
Considerando a cultura organizacional da empresa, não seria possível determinar que a nova função (gerente de projetos) tivesse um nível de poder maior que o das gerências funcionais. O máximo que se considera possível é um nível de poder equivalente.

> A balança de poder entre os gerentes funcionais e os gerentes de projetos seria definida no decorrer do tempo, a partir da eficiência e competência de cada um dos lados. Como a função dos gerentes de projetos é uma função nova, no início dos trabalhos os gerentes de projetos teriam um nível de poder inferior aos gerentes funcionais. E este nível só seria aumentado, de acordo com a competência e os resultados apresentados pelos gerentes de projetos. À medida que os resultados fossem sendo apresentados, os gerentes de projetos aumentariam seu nível de influência e poder, até estes serem igualados aos dos gerentes funcionais. Porém, dificilmente os gerentes de projetos teriam um poder e influência superior aos das gerências funcionais.

> A responsabilidade pela alocação dos recursos continuaria com as Gerências Funcionais, o que limita muito a atuação dos gerentes de projetos.

$>$ A equipe do projeto continuaria sendo alocada em tempo parcial nos projetos.

Portanto, conclui-se que o posicionamento do EGP da LogB foi realizado de maneira compatível para a situação de ter ou não ter gerentes de projetos alocados dentro de seu EGP. Mostra que a decisão pelo posicionamento do EGP na estrutura organizacional foi acertada, se mostrando flexível e eficaz para diversos tipos de situação.

O terceiro fator de influência sobre o posicionamento do EGP na estrutura organizacional é a associação entre as funções designadas ao EGP com o nível de autoridade desejado ao EGP, conforme discutido no item 3.3.7.5.2.

A primeira análise a ser feita é entender como cada função atribuída ao EGP tem responsabilidade sobre os resultados dos projetos. Para tanto, a Tabela 10 foi elaborada considerando as funções do EGP da LogB (Tabela 15), gerando a Tabela 16. 


\begin{tabular}{|c|l|c|c|c|}
\hline \multicolumn{2}{|c|}{ Grupo de Funções } & $\begin{array}{c}\text { Execução } \\
\text { Direta } \\
\text { dos } \\
\text { Projetos }\end{array}$ & $\begin{array}{c}\text { Execução } \\
\text { Indireta } \\
\text { dos } \\
\text { Projetos }\end{array}$ & $\begin{array}{c}\text { Apoio } \\
\text { nos } \\
\text { Projetos }\end{array}$ \\
\hline 1 & Gerenciamento Estratégico & & Parcial & \\
\hline 2 & Gerenciamento de Múltiplos Projetos & & & \\
\hline 3 & Gestão de Recursos & Sim & & \\
\hline 4 & Gestão da Execução & & Sim & \\
\hline 5 & Planejamento & & & Sim \\
\hline 6 & Monitoramento e Controle do Desempenho & & Sim \\
\hline 7 & Desenvolvimento das Competências e Metodologias & & & Sim \\
\hline 8 & Ferramentas & & & Sim \\
\hline 9 & Aprendizado Organizacional & & & \\
\hline 10 & Interface com Clientes & & \\
\hline
\end{tabular}

Tabela 16: Grupos de Funções x Responsabilidade atribuída ao EGP da LogB ${ }^{10}$ (Fonte: autor)

A Tabela 16 representa os grupos de funções designados ao EGP da LogB, classificando-as sob seu nível de influência nos resultados dos projetos, de acordo com o item 3.3.7.5.2.

Como pode ser observado na Tabela 16, o EGP tem funções divididas nos três tipos de classificação. Cada um destes tipos influencia de forma diferente 0 posicionamento do EGP na estrutura organizacional. A seguir é analisado como ocorre esta influência.

Para que o EGP da LogB possa exercer as funções relacionadas ao apoio à gestão de projetos, o posicionamento do EGP na estrutura organizacional não teve o impacto muito alto. Como suas funções estão relacionadas ao apoio no processo de gestão e não à gestão e execução dos projetos em si, independentemente de sua posição na estrutura organizacional, o EGP poderá realizar suas atividades. Entretanto, o fato do EGP ter sido posicionado numa posição hierarquicamente alta da estrutura organizacional, deu a ele força suficiente para se impor perante as outras áreas e gerências funcionais. Possibilitou, portanto, que o EGP tivesse força

\footnotetext{
${ }^{10}$ Foi considerado "Sim" quando a maioria ou as mais relevantes funções do grupo foram designadas ao EGP da LogB. E foi considerado "Parcial" quando apenas uma pequena parte ou as menos relevantes funções do grupo foram designadas ao EGP da $\operatorname{LogB}$.
} 
de influência capaz de promover um processo de mudança de cultura, de desenvolvimento metodológico e de melhoria contínua.

Para as funções relacionadas à execução indireta dos projetos, algumas funções exigem um posicionamento mais alto na estrutura organizacional, como 0 desenvolvimento da integração entre áreas e departamentos, realização de benchmarking e a elaboração de estudos sobre a capacidade de realização de projetos da empresa. Outras, como a realização do planejamento dos projetos, podem ser executados em qualquer posicionamento do EGP na estrutura organizacional. Portanto, como o EGP da LogB está inserido numa alta posição da estrutura organizacional, foi viabilizada a execução destas funções.

Já para as funções que tem responsabilidade direta pela execução dos projetos, o impacto no posicionamento do EGP na estrutura organizacional é muito alto. Dependendo deste posicionamento, os gerentes de projetos terão maior, equivalente ou menor poder perante aos gerentes funcionais, determinando também o tipo de estrutura organizacional no qual a empresa irá gerir seus projetos (funcional, matricial ou projetizada). O posicionamento do EGP como definido na LogB permite uma alteração na estrutura organizacional de funcional para matricial balanceada, dependendo do nível de competência dos gerentes de projetos da LogB, conforme comentado anteriormente e ilustrado na Figura 28. Dessa forma, apesar da execução dos projetos não estar incluída entre as funções atribuídas inicialmente ao EGP da LogB, o seu alto posicionamento na estrutura organizacional viabilizou que o EGP assumisse também esta responsabilidade.

Desse modo, o EGP foi posicionado na estrutura organizacional de forma que atendeu as necessidades de influência e poder de todas suas funções.

Como conclusão, as análises apresentadas no item 3.3.7 também se mostraram aplicáveis à situação real da LogB. Os problemas relacionados à utilização de uma estrutura funcional estão coerentes com os apresentados no item 3.3.7.1. O posicionamento do EGP na estrutura organizacional da LogB atende os três fatores apresentados no item 3.3.7.5: a necessidade de haver um ou mais EGP na organização; os gerentes de projetos estarem ou não dentro do EGP (coerente com 
as idéias apresentadas no item 3.3.7.5.1); e a associação entre as funções com o nível de autoridade desejado para o EGP (também coerente com as idéias apresentadas no item 3.3.7.5.2).

\subsubsection{O Tipo do EGP}

Para a constituição do EGP da LogB, durante os vários momentos onde se discutiu o planejamento do EGP (Figura 22 - planejamento informal, planejamento dos anos, planejamento estratégico), não se chegou a discutir qual seria o tipo de EGP a ser implantado na LogB.

As discussões ocorreram sobre as funções que seriam atribuídas ao EGP e como elas seriam implementadas.

Depois que as funções foram estabelecidas, com o intuito apenas de facilitar a comunicação entre a equipe do EGP e outros stakeholders, foi analisada em qual tipo de EGP o EGP da LogB se encaixaria.

A conclusão foi que o EGP passou por dois tipos de classificação durante sua existência: uma antes e outra depois de assumir a responsabilidade pela gestão da execução de alguns projetos.

Antes de assumir a responsabilidade pela gestão da execução dos projetos, o tipo do EGP era:

> Modelo do Dinsmore (1998): Project Management Center of Excellence;

$>$ Modelo de Verzuh (2005): Center of Excellence;

> Modelo de Casey e Peck (2001): Control Tower.

Após o EGP assumir a responsabilidade pela gestão da execução de alguns projetos, o tipo de EGP alterou para: 
> Modelo do Dinsmore (1998): Program Management Office, incluindo o Project Support Office e o Project Management Center of Excellence. Porém, não possui todas as funções destes tipos (por exemplo, não tem a responsabilidade pela gestão do portfólio);

$>$ Modelo de Verzuh (2005): Accountable Project Office, incluindo o Project Support Office e o Center of Excellence. Porém, não possui todas as funções destes tipos (por exemplo, não tem a responsabilidade pela gestão do portfólio e não assume sozinho a responsabilidade pela execução e resultados dos projetos);

> Modelo de Casey e Peck (2001): Resource Pool mais Control Tower. Porém, as características destes dois tipos não compreendem todas as características do EGP da LogB.

A definição do tipo de EGP da LogB para a situação após ele assumir a responsabilidade pela gestão da execução de alguns projetos, mostrou de forma evidente a preocupação de Hobbs e Aubry (2007) de que o cenário real das empresas onde esses EGP são aplicados é muito mais complexo do que as tipologias apresentadas, sendo difícil coincidir completamente as características de um tipo de EGP numa situação real, opinião que também foi defendida por Casey e Peck (2001).

O caso na $\operatorname{LogB}$ ora analisado corrobora as análises apresentadas no item 3.3.5, ficando evidente que a definição dos tipos de EGP é na realidade uma combinação das funções e autoridade designadas ao EGP, conforme apresentado por Verzuh (2005) e que a tipificação dos EGP conforme referências disponíveis dificilmente atenderá perfeitamente as necessidades particulares de uma empresa (HOBBS e AUBRY, 2007; CASEY e PECK, 2001).

Portanto, conclui-se que, na fase de planejamento da criação do EGP, é fundamental discutir separadamente as funções e a autoridade (estrutura organizacional) que o EGP terá, ao invés de discutir qual o tipo de EGP deveria ser aplicado à empresa. 


\subsubsection{A Influência da Cultura Organizacional}

Dinsmore (2002), Crawford (2002) e Block e Frame (1998) associam a implantação de um EGP a um processo de gestão de mudança de cultura organizacional, ou seja, um processo onde é necessário lidar com as resistências das pessoas. Neste item é analisado como a cultura organizacional impactou na implantação do EGP da LogB.

Analisando todo o processo de implantação das práticas de gestão de projetos na LogB, desde início de 2004 (Figura 22), pode-se afirmar que sempre houve uma forte resistência das pessoas da organização, em todos os seus níveis (operacional, média e alta gerência).

Coerente com a opinião de Crawford (2002), apresentado no item 3.3.8, não houve no processo de implantação do EGP da LogB um consenso entre as pessoas da organização. Alguns achavam que os custos necessários para sua implantação não valeriam a pena; outros achavam que o EGP iria aumentar a burocracia na empresa e consequentemente, aumentaria o tempo necessário para a execução dos projetos na empresa; outros ainda achavam que a implantação do EGP iria retirar poder das mãos das gerências funcionais e transferi-las ao EGP e às Unidades Operacionais. É interessante notar que estas formas de resistências estão de acordo com as apresentadas por Block e Frame (1998) no item 3.3.8.

Uma característica da cultura organizacional desta empresa é sua grande dispersão geográfica. A empresa tem escritórios espalhados por todo o país e uma estrutura administrativa dividida em quatro regionais, conforme comentado anteriormente. $\mathrm{E}$ além da natural diferença cultural da população dessas quatro regiões, a forma de pensar, de trabalhar, os interesses e expectativas eram todos muito diferentes. Devido a isso, a forma como eram gerenciados os projetos em cada uma das quatro regiões era muito diferente uma das outras. Considerando isso, todas as ações do EGP da LogB tinham que ser adaptadas para cada uma das regionais. Esta característica foi, inclusive, uma das que indicaram a necessidade de se constituir o EGP com quatro regionais. 
As diferenças de cultura entre as quatro regionais geravam situações nas quais existiam funções do EGP que eram viáveis de implantação em uma regional, mas não eram viáveis em outras. Um exemplo é a oportunidade do EGP em gerenciar a execução dos projetos. Na regional Sul, esta função era viável de ser implantada, pois havia interesse dos stakeholders locais em passar estas atividades ao EGP. Porém, esta mesma função era inviável de ser implantada na regional SPCO, pois os stakeholders locais consideravam que esta função era de responsabilidade das gerências funcionais locais e não estavam dispostos a transferir esta responsabilidade ao EGP.

Kerzner (2003), no item 3.3.8, apresenta uma forma de classificar os níveis de resistência em uma implantação de EGP. Na LogB, as funções do EGP ficariam assim classificadas:

> Baixo risco: elaboração de procedimentos, treinamentos e mentoring;

> Médio risco: elaboração de relatórios de progresso e lições aprendidas;

> Alto risco: disseminação da informação, benchmarking e estudos da capacidade de realização.

$\mathrm{Na}$ LogB, o EGP teve realmente baixos níveis de resistência quando se propôs a atuar na elaboração dos procedimentos de gestão de projetos, na realização de treinamentos e nas atividades de mentoring.

Entretanto, já teve níveis moderados de resistência quando resolveu montar seções de lições aprendidas de alguns empreendimentos. Houve também moderado nível de resistência na utilização da ferramenta de gestão de projetos, sendo que um dos motivos para esta resistência era o receio de mostrar informações dos projetos a todos os interessados, principalmente os que os comprometiam com prazos planejados.

Quanto às atividades de benchmarking e estudos da capacidade de realização, até o presente momento o EGP não começou a realizá-los, portanto, não é possível identificar o nível de resistência. Para a atividade de disseminação da informação, 
aplica-se os mesmos comentários do parágrafo anterior que trata da utilização da ferramenta de gestão de projetos.

É interessante notar que há coerência entre a forma de classificação dos níveis de resistência apresentado por Kerzner (2003) e os resultados apresentados na implantação do EGP na LogB.

Um outro ponto importante a ser lembrado em um processo de mudança de cultura organizacional é apresentado por Fischer (2002), a qual diz que a transformação organizacional só se efetiva com as pessoas, para as pessoas e através do envolvimento e do comprometimento das pessoas. Neste caso, em algumas situações, o EGP da LogB prestou menor atenção a este fator do que o necessário. Um exemplo foi a priorização das ações do EGP na implantação da ferramenta de gestão de projetos desenvolvida internamente, ao invés de priorizar ações que buscassem o comprometimento e o respaldo dos diversos níveis da organização com a implantação do EGP e com as práticas da gestão de projetos. Esta priorização na busca do comprometimento, respaldo e integração dos departamentos sobre a implantação de ferramentas e aplicativos também é defendida por Rad e Raghavan (2000). Na LogB, a implantação de sua ferramenta encontrou grandes dificuldades de aceitação e utilização pelos vários níveis organizacionais (operacional, média e alta gerência), justamente pela deficiência no processo de obter comprometimento dos vários stakeholders da organização.

Entretanto, a equipe do EGP argumenta que pela alta qualidade da ferramenta de gestão de projetos desenvolvida pelo departamento, a ferramenta deveria ser utilizada como um modo de ganhar o comprometimento das pessoas, pois o EGP estaria fornecendo um sistema que iria facilitar a vida de seus usuários. Deste modo, a ferramenta poderia servir como uma forma de quebrar resistências dentro da organização.

A opinião do autor a este respeito, é que mesmo com a alta qualidade da ferramenta desenvolvida, o software não conseguirá ganhar ou melhorar o comprometimento dos usuários nem diminuir as resistências pela implantação do EGP. A opinião do autor é que tentar implantar um software sem que o comprometimento dos diversos 
níveis gerenciais tenha sido obtido irá gerar uma maior resistência por parte de todos os usuários, que não se sentirão confortáveis nem com interesse pela sua utilização. Neste caso, os usuários sempre apresentarão um motivo para justificar sua não utilização, como por exemplo: o software não está funcionando, o software não atende as necessidades ou o software está atrasando suas tarefas. Ou seja, a implantação de um software é também um processo top-down, no qual deve ser obtido o comprometimento dos altos níveis gerenciais, depois da média gerência para então chegar ao nível operacional.

A resistência pela implantação do EGP também ocorreu devido a pouca prioridade dada no início dos trabalhos do EGP em comunicar e divulgar os objetivos e os benefícios pelos quais esta estrutura estava sendo implantada. Block e Frame (1998) concordam que um eficiente processo de comunicação pode diminuir as resistências ao EGP. No decorrer da implantação, este processo de comunicação foi melhorado, mas acredita-se que um aprimoramento na comunicação permita uma redução adicional nas resistências. O autor também acredita que esta comunicação está relacionada com a busca pelo respaldo e comprometimento das áreas e dos stakeholders, pois uma melhor comunicação dos objetivos e funções do EGP poderia mostrar os benefícios a serem gerados e a minimizar os receios de troca de poder das pessoas da organização com a entrada do EGP.

Uma situação no qual o EGP da LogB teve de aprender a atuar foi tentar identificar qual seria a carga de trabalho que os profissionais da empresa poderiam suportar para realizar a gestão dos projetos. Ou seja, buscar entender qual é o nível de trabalho para gerir os projetos as áreas ou pessoas tinham condições de suportar, considerando suas outras atribuições, sem perder a qualidade de seu trabalho. A situação ideal seria a empresa fornecer a quantidade de recursos adequada para a condução de seus projetos, mas a realidade das empresas em qualquer lugar do mundo é de trabalhar com menos recursos do que é o necessário. Portanto, entender qual é o nível de trabalho adequado que as pessoas tem condições de suportar é importante para minimizar as resistências do EGP.

Dois fatores contribuíram para a minimização das resistências. O primeiro foi a concentração de esforços do EGP na realização de treinamentos para todos os 
níveis organizacionais, buscando com isso construir uma massa crítica de pessoas com conhecimento em gestão de projetos. O segundo foi o posicionamento adequado do EGP na estrutura organizacional, permitindo que sua gerência tivesse influência suficiente para buscar respaldo e comprometimento em todos os níveis gerenciais da organização.

Como conclusão, as análises apresentadas no item 3.3.8 se mostraram aplicáveis à situação real da LogB. Todas as formas de resistências apresentadas neste item se mostraram reais na implantação do EGP da LogB.

\subsubsection{A Influência da Maturidade em Gestão de Projetos}

Segundo Kerzner (2002), a maturidade em gestão de projetos é um meio de analisar o quanto a organização já caminhou no sentido de obter a excelência em gestão de projetos e prover uma base que permita estabelecer as ações e práticas necessárias para alcançá-la.

No processo de planejamento e implantação do EGP da LogB, não foi realizada uma avaliação formal do seu nível de maturidade. O senso comum da equipe do EGP indicava que o nível de maturidade da empresa era o mais básico possível, o equivalente ao nível Linguagem Comum (nível 1) do método proposto por Kerzner (2001b). Portanto, a equipe do EGP não considerou relevante naquele momento a aplicação do método para validar este nível de maturidade.

Entretanto, com o intuito de avaliar as discussões apresentadas no item 3.3.9, 0 autor aplicou a avaliação da maturidade na LogB. O modelo utilizado foi o PMMM, do Kerzner (2001b). A avaliação considera a atual situação da gestão de projetos na empresa, ou seja, aplicada no início de 2008 (Figura 22). A avaliação foi realizada exclusivamente com a opinião do autor desta dissertação, que participa da implantação deste EGP desde seu início e tem as informações necessárias para responder o questionário de avaliação do método. Apesar deste não ser o procedimento recomendado, ele foi utilizado por não haver condições de se realizar uma pesquisa mais ampla na empresa. Para não se perder a oportunidade de se 
realizar as análises da aplicação deste método, este foi aplicado com as opiniões do autor. Com os dados obtidos da avaliação, são apresentadas análises com os seguintes objetivos: avaliar a aplicabilidade do método PMMM no EGP da LogB; e avaliar a aplicabilidade das recomendações apresentadas no item 3.3.9.2 no EGP da LogB. Os dois itens seguintes apresentam estas análises.

\subsubsection{Avaliação da Maturidade}

Para avaliação do nível de maturidade, o modelo PMMM fornece um questionário que avalia o ciclo de vida do Nível 2 (Processos Comuns). O questionário utiliza a escala de "-3" (discordo totalmente) à "+3" (concordo totalmente). O questionário do modelo é apresentado no Anexo $1^{11}$.

As respostas de cada questão foram as seguintes (Tabela 17):

\begin{tabular}{|c|c|}
\hline Questão & Resposta \\
\hline 1 & +1 \\
\hline 2 & -3 \\
\hline 3 & +1 \\
\hline 4 & +3 \\
\hline 5 & -2 \\
\hline
\end{tabular}

\begin{tabular}{|c|c|}
\hline Questão & Resposta \\
\hline 6 & -2 \\
\hline 7 & -2 \\
\hline 8 & -2 \\
\hline 9 & -2 \\
\hline 10 & -1 \\
\hline
\end{tabular}

\begin{tabular}{|c|c|}
\hline Questão & Resposta \\
\hline 11 & +3 \\
\hline 12 & -1 \\
\hline 13 & -1 \\
\hline 14 & +1 \\
\hline 15 & -1 \\
\hline
\end{tabular}

\begin{tabular}{|c|c|}
\hline Questão & Resposta \\
\hline 16 & +2 \\
\hline 17 & +1 \\
\hline 18 & -2 \\
\hline 19 & +1 \\
\hline 20 & +1 \\
\hline
\end{tabular}

Tabela 17: Respostas do Questionário PMMM na LogB

(Fonte: autor)

Conforme o método PMMM, cada pergunta da Tabela 17 relaciona-se com uma fase do ciclo de vida da maturidade e seu somatório, conforme indicado pelo método, indica a quantidade de pontos obtidos para cada fase. O Anexo 1 apresenta 0 relacionamento de cada pergunta com sua respectiva fase. Segundo Kerzner (2001b), uma pontuação alta, usualmente igual ou superior a +6 , indicaria que aquele estágio de evolução da maturidade havia sido atingido.

O resultado da aplicação do questionário indicou a seguinte pontuação para cada fase do ciclo de vida da maturidade na LogB (Tabela 18):

\footnotetext{
11 Apesar do método PMMM possuir questionário de avaliação de todos os níveis de maturidade, nesta dissertação foi aplicado apenas o questionário referente ao Nível 2, pois é o que mais se aproxima da situação atual da gestão de projetos na empresa LogB. O Anexo 1 apresenta apenas este questionário.
} 


\begin{tabular}{|c|c|c|c|c|}
\hline Embrionário & $\begin{array}{c}\text { Aceitação pela } \\
\text { Gerência Executiva }\end{array}$ & $\begin{array}{c}\text { Aceitação pelos } \\
\text { Gerentes de Área }\end{array}$ & \multicolumn{1}{c|}{ Crescimento } & Maturidade \\
\hline+4 & -3 & -4 & +2 & -4 \\
\hline
\end{tabular}

Tabela 18: Pontuação do Ciclo de Vida do PMMM na LogB

(Fonte: autor)

É interessante notar que o resultado desta avaliação é muito coerente com a atual situação da gestão de projetos na LogB e consequentemente, da implantação de seu EGP, conforme pode ser verificado nos parágrafos seguintes.

A aplicação do método PMMM conclui que a LogB está no nível 2 de maturidade, chamado Processos Comuns. A fase Embrionária está bem evoluída, as fases de Aceitação pela Gerência Executiva e pelos Gerentes de Área estão bem atrasadas, há muitas atividades sendo executadas referentes à fase de Crescimento e a fase da Maturidade ainda não foi alcançada.

Analisando as características de cada fase do ciclo de vida da maturidade, tem-se:

> Embrionária: esta é a fase em que a empresa reconhece a necessidade e os benefícios da gestão de projetos. Na LogB, há por parte de uma boa parcela das pessoas, um reconhecimento da necessidade de se investir na gestão de projetos para que se possa melhorar os resultados dos empreendimentos na empresa. Entretanto, como a empresa é grande, não é possível afirmar que todas as pessoas da empresa já possuem este reconhecimento. Mas atualmente, o número de pessoas que reconhecem a necessidade da gestão de projetos é bem maior do que quando se iniciou as primeiras atividades (início de 2004). Isto é reflexo dos treinamentos administrados e das ações do EGP em promover a gestão de projetos na organização. É interessante notar a coerência das características propostas por Kerzner (2001b), o qual diz que normalmente este reconhecimento ocorre primeiro nos níveis gerenciais mais baixos. $\mathrm{Na} \operatorname{LogB}$, os primeiros reconhecimentos ocorreram em um departamento de nível hierárquico mais baixo e dele se proferiu as idéias para atingir a alta administração. Um outro ponto que atesta que a fase embrionária está avançada é a própria existência do 
EGP da LogB. Haver um EGP na empresa significa que a alta administração está pelo menos investindo no desenvolvimento da gestão de projetos.

Aceitação pela Gerência Executiva: esta é a fase em que a alta administração aceita e apóia visivelmente a implantação das práticas de gestão de projetos. $\mathrm{Na}$ LogB, é possível observar que os executivos da empresa reconhecem a necessidade de se melhorar a forma como se gerencia os empreendimentos na empresa. Observa-se que eles entendem os benefícios que a gestão de projetos pode trazer e por isso investem na implantação do EGP. Entretanto, observa-se também que o nível de conhecimento sobre a disciplina de gestão de projetos pode ser considerado básico e o maior sinal de que esta fase ainda está atrasada é que não há muitas evidências de apoio visível por parte dos executivos com a implantação do EGP e das práticas de gestão de projetos. Observa-se que ainda não foi atingido um nível satisfatório de respaldo e comprometimento por parte dos vários executivos da empresa, nem foi atingido um nível de integração dos departamentos de modo a favorecer a aplicação da gestão de projetos.

Aceitação pelos Gerentes de Área: esta é a fase em que os gerentes de área reconhecem e apóiam visivelmente a implantação das práticas de gestão de projetos. $\mathrm{Na}$ LogB, apesar dos gerentes de área saberem que há necessidade de se melhorar a forma como se gerencia os empreendimentos da empresa, eles ainda agem com muita resistência na aplicação da gestão de projetos, devido aos vários fatores ligados a cultura organizacional comentados no item 4.4.8. Os três fatores mais relevantes é o receio da troca de poderes, o receio de aumento do volume de trabalho e o receio de maior controle sobre suas atividades. Esta situação é agravada por haver gerentes executivos que ainda não apóiam visivelmente a implantação da gestão de projetos. Observa-se, portanto que esta fase está atrasada devido a falta de um nível satisfatório de respaldo e comprometimento por parte dos gerentes de área e também por ainda não ter sido atingido um nível satisfatório de integração das áreas de modo a favorecer a aplicação da gestão de projetos. 
> Crescimento: esta é a fase onde ocorre o início da criação dos processos de gestão de projetos. Na LogB, já foi desenvolvida a metodologia de gestão de projetos, a qual inclui a definição do ciclo de vida de projetos na organização. Está sendo também desenvolvida e implantada uma ferramenta de gestão de projetos, que apóia a aplicação da metodologia e o controle do portfólio de projetos. O EGP também está buscando mudar o foco das atividades da fase de execução dos projetos para sua fase de planejamento. Entretanto, a fase não está concluída, pois para que estivesse concluída, seria necessário que a maioria de seus projetos estivesse aplicando a metodologia, a ferramenta e focando a fase de planejamento. Esta ainda não é a realidade da empresa e, portanto, é coerente que a fase não tenha sido concluída. É interessante notar a coerência das características apresentadas por Kerzner (2001b) para esta fase, como a que diz ser normal que atividades desta fase ocorram em paralelo com as atividades das três fases anteriores. Foi exatamente como ocorreu na LogB, com as atividades de desenvolvimento da metodologia e da ferramenta de gestão de projetos sendo realizadas desde início de 2004. Segundo Kerzner (2001b) este paralelismo é possível, porém sem o atingimento dos objetivos das três fases anteriores, não é possível considerar concluída esta fase de crescimento.

Maturidade: esta é a fase onde se alcança a maturidade inicial da empresa. Dentre as atividades previstas para o atingimento desta fase, já foi realizado na LogB o desenvolvimento de um programa de treinamento em gestão de projetos para todas as pessoas que tenham envolvimento com projetos.

Portanto, conclui-se que as características atuais da implantação das práticas de gestão de projetos na LogB estão compatíveis com as características do nível de maturidade em gestão de projetos para o Nível 2 (Processos Comuns), segundo o modelo PMMM.

É interessante ainda notar que o resultado da avaliação mostra claramente a raiz dos problemas enfrentados atualmente na empresa para continuar com a implantação das práticas de gestão de projetos na LogB. Conforme pode ser observado na Figura 29, as ações referentes às fases Embrionária e Crescimento estão bem adiantadas na empresa. Entretanto, as ações referentes às fases de 
Aceitação pela Gerência Executiva e pelos Gerentes de Área ainda estão muito atrasadas. E segundo Kerzner (2001b), a fase de Crescimento e consequentemente a de Maturidade não são alcançadas se não forem atingidos por completo os níveis de aceitação pela gerência executiva e pelos gerentes de área. Este assunto também foi abordado diversas outras vezes nesta dissertação, afirmando que sem o apoio visível da alta e média administração, não é possível implantar um EGP nem as práticas de gestão de projetos. Esta baixa pontuação obtida nas fases de Aceitação pela Gerência Executiva e pelos Gerentes de Área revela os motivos para os grandes focos de resistência da empresa.

Esta avaliação da maturidade da LogB revela a necessidade de continuar com as atividades de desenvolvimento da metodologia e da ferramenta, porém priorizando a busca pelo respaldo e comprometimento dos gerentes executivos e gerentes de área para a aplicação da gestão de projetos na organização.

\begin{tabular}{|c|c|c|c|c|c|c|c|c|c|c|c|c|c|c|c|c|c|c|c|c|c|}
\hline & -9 & -8 & -7 & -6 & -5 & -4 & -3 & -2 & -1 & 0 & & & 2 & 3 & 4 & 5 & 6 & 7 & 8 & & 9 \\
\hline Embrionári & & & & & & & & & & & & & & & & & & & & & \\
\hline Aceitação p & & & & & & & & & & & & & & & & & & & & & \\
\hline Aceitação & & & & & & & & & & & & & & & & & & & & & \\
\hline Cresciment & & & & & & & & & & & & & & & & & & & & & \\
\hline Maturidade & & & & & & & & & & & & & & & & & & & & & \\
\hline
\end{tabular}

Figura 29: Gráfico de Pontuação do Ciclo de Vida do PMMM na LogB (Fonte: autor)

No modelo PMMM, Kerzner (2001b) também apresenta um levantamento das formas mais comuns de resistência de acordo com o nível de maturidade (item 3.3.9.1). É interessante notar que na $\operatorname{LogB}$, as resistências apontadas para o nível 1 e nível 2 continuam acontecendo na organização. Ainda há o receio da troca de poderes, receio no uso da metodologia e da ferramenta, receio da rigidez das políticas e procedimentos. E surgem comentários do tipo: "nós não precisamos disto", "isto não se aplica aos nossos negócios", "ficaremos melhores sem isto", "a forma como trabalhamos hoje já funciona bem", "isto só vai trazer mais trabalho e burocracia". O fato das características de resistência do nível 1 ainda aparecerem atualmente na empresa, fortalece a conclusão de que a fase Embrionária ainda não está concluída. 
Como conclusão, as análises apresentadas no item 3.3.9 se mostraram aplicáveis à situação real da LogB. As características propostas pelo modelo PMMM do Kerzner (2001b) no item 3.3.9.1, se mostraram totalmente coerentes com a situação real da gestão de projetos na $\operatorname{LogB}$, revelando ainda a fonte dos problemas enfrentados atualmente para aplicação da gestão de projetos na LogB. As formas mais comuns de resistência por nível de maturidade apresentadas por Kerzner (2001b) também são verificadas na LogB.

\subsubsection{Relacionamento entre a Maturidade e o EGP}

Como apresentado no item 3.3.9.2, é importante customizar a implantação de um EGP para que este esteja adequado ao nível de maturidade em gestão de projetos da empresa.

Conforme Andersen, Henriksen e Aarseth (2006), a maturidade está relacionada com a criação das fases de implantação do EGP. Entretanto, outros tópicos, como os apresentados no item 3.3.9.2, também influenciam na criação destas fases.

Este item tem o intuito de analisar se as funções realizadas atualmente pelo EGP da LogB está compatível com seu nível de maturidade.

Como a LogB não definiu fases para sua implantação, considera-se que o EGP dela esteja atuando em todas as funções atribuídas ao EGP, conforme Tabela 15. O nível de maturidade atual da LogB é o Processos Comuns (nível 2), sendo que as fases embrionária e crescimento estão mais avançadas e as fases de aceitação pela gerência executiva e gerentes de área estão mais atrasadas.

Para o nível 2 de maturidade, as idéias apresentadas no item 3.3.9.2 propõem o seguinte:

> Andersen, Henriksen e Aarseth (2006) sugerem iniciar as atividades do EGP com atividades e ações menos complexas e mais fáceis de implantar; 
> Dinsmore (2002), Crawford (2002) e Block e Frame (1998), que associam a implantação de um EGP a um processo de mudança de cultura organizacional, dizem que para empresas de baixo nível de maturidade, o início da implantação de um EGP deve priorizar ações com menor barreira e resistência de seus funcionários;

> Kerzner (2001b) também sugere iniciar a implantação de um EGP com funções e atividades que possuem menor potencial de risco.

Portanto, conclui-se que a estratégia adotada pela LogB para implantação de seu EGP é uma estratégia de elevado risco, pois ela está buscando realizar todas as atividades atribuídas a seu EGP ao mesmo momento, praticamente em paralelo. Tanto atividades de menor risco, como por exemplo, treinamento, como atividades de maior risco, como por exemplo, fazer a gestão da execução dos projetos, estão sendo implantadas ao mesmo tempo.

Esta estratégia aumenta os riscos envolvidos no processo de implantação do EGP, pois diminui o foco de atenção sobre as funções principais do EGP relacionadas ao seu nível de maturidade. Conforme as idéias apresentadas no item 3.3.9.2, e reforçadas pelo resultado da aplicação da avaliação da maturidade na LogB (item 4.4.9.1), o foco das atenções do EGP da LogB deveria ser buscar o respaldo e o comprometimento da gerência executiva e dos gerentes de área. Só a partir da obtenção destes apoios é que o EGP deveria se comprometer com funções mais complexas como fazer a gestão da execução dos projetos.

Para que se estivesse adequado as funções atribuídas ao EGP com o seu nível atual de maturidade em gestão de projetos, a LogB deveria ter criado fases de implantação para seu EGP. De acordo com as idéias apresentadas no item 3.3.9.2, os próximos parágrafos apresentam quais poderiam ser as fases de implantação do EGP da LogB, com as respectivas funções atribuídas a cada fase.

Considerando três fases de implantação (curto, médio e longo prazo), as atividades de curto prazo do EGP deveriam ser: treinamento focado para os gerentes e executivos; campanhas de promoção dos benefícios da gestão de projetos; ações que promovem a mudança de cultura; mentoring e ações para buscar o respaldo e 
comprometimento da gerência executiva. Dessa forma, o EGP estaria atuando com atividades que oferecem menor risco e com menores possibilidades de enfrentar barreira e resistência dos funcionários da empresa.

Entretanto, como o EGP da LogB já está avançado no desenvolvimento da metodologia e da ferramenta de gestão de projetos, estas duas atividades não deveriam ser interrompidas, mas deve-se deixar claro que a prioridade está na busca de obtenção de respaldo e comprometimento dos executivos e gerentes de área.

Para médio prazo, já com um melhor apoio e respaldo da gerência executiva, a possibilidade de o EGP enfrentar resistência das pessoas seria minimizada, permitindo ao EGP começar a atuar em atividades um pouco mais complexas. Assim, as atividades foco do EGP deveriam ser: treinamento básico de gestão de projetos para todos os funcionários da empresa envolvidos em projetos; continuar o processo de mudança de cultura, principalmente reforçando o foco nas atividades de planejamento do projeto; mentoring; consultoria; desenvolvimento e aplicação da metodologia e da ferramenta de gestão de projetos; desenvolver a integração entre departamentos; fornecer suporte ao planejamento; e desenvolver a base da ferramenta para gerenciar os dados, histórico, riscos e lições aprendidas dos projetos.

Para o longo prazo, já haveria apoio visível das gerências executivas e das gerências de áreas, além de toda a base de suporte ao trabalho do EGP já estaria montada: metodologia e ferramenta bastante avançadas, equipe treinada, funcionários treinados e processo de mudança de cultura avançado. Os maiores riscos de resistência das pessoas estaria também minimizado. Portanto, o EGP estaria apto a atuar nas atividades mais complexas e que demandariam maior tempo para ser solucionadas. Assim, as atividades foco do EGP deveriam ser: garantir que todos os projetos apliquem a metodologia (auditorias); aplicar e gerenciar a base de dados, histórico, riscos e lições aprendidas dos projetos; fornecer suporte ao planejamento; fazer a gestão da execução dos projetos mais importantes; desenvolver a metodologia singular com base na gestão de projetos; treinamento avançado em gestão de projetos; planejar a capacidade de realização de projetos da 
empresa $^{12}$; desenvolver a integração entre departamentos; consultoria; e monitorar e controlar o desempenho dos projetos.

Como conclusão, as análises apresentadas no item 3.3.9.2 se mostraram aplicáveis à situação real da LogB. A necessidade de definição de fases de implantação conforme o nível de maturidade da empresa e a proposta de associação de funções atribuídas pelo EGP com o seu nível de maturidade apresentado na Figura 19 se mostraram coerentes quando comparadas com a situação real da LogB.

\subsubsection{A Influência dos Fatores Críticos de Sucesso}

Os fatores críticos de sucesso contribuem para diminuir os riscos de uma implantação de EGP. Com base nos fatores críticos identificados no item 3.3.10, este item analisa como estes fatores influenciaram a implantação do EGP na LogB.

> Patrocínio da alta administração: dois pontos podem ser considerados como contribuintes para obtenção deste patrocínio. Um é a posição no qual o EGP foi inserido na estrutura organizacional. Sua posição relativamente alta permite um acesso direto à alta administração e um considerável poder de influência perante as outras áreas da empresa. Outro foi o patrocínio obtido da presidência da empresa, o qual autorizou o investimento na constituição do EGP. A obtenção deste patrocínio foi fundamental para que o EGP exercesse suas funções e tivesse liberdade de atuação em todos os níveis organizacionais. Porém, para que as funções atribuídas ao EGP sejam executadas e benefícios previstos sejam obtidos, como comentado anteriormente no item maturidade, é necessário que este patrocínio se traduza em ações mais visíveis de apoio ao EGP direcionadas a todos os funcionários da empresa. É necessário que este patrocínio se traduza em um maior respaldo e comprometimento de todos os executivos, gerentes de área e coordenadores com a aplicação das práticas de gestão de projetos.

\footnotetext{
12 Planejar a capacidade de realização de projetos da empresa: significa identificar qual é a quantidade de projetos que a empresa tem recursos (humanos, materiais e financeiros) para realizar. Esta informação deve ser utilizada pela Gestão de Portfólio para apoiar na definição da carteira de projetos da empresa.
} 
> Manter a implantação o mais simples possível: como comentado anteriormente, não foram definidos focos de atuação do EGP da LogB. Devido a isso, o EGP se envolveu em diversas frentes de atividades, o que tornou o processo mais complexo do que o necessário. Como comentado no item dos Objetivos Estratégicos (item 3.3.4), é necessário que sejam definidos os objetivos e os distribua em fases de implantação, deixando as atividades mais simples no curto prazo e as mais complexas no longo prazo. Em uma outra interpretação deste fator crítico, é importante ressaltar a importância por se tomar decisões e buscar soluções simples na implantação do EGP. Algumas vezes, na LogB, em busca da solução perfeita, acabava-se por se adotar soluções muito complexas para utilização (principalmente por usuários de nível básico em gestão de projetos) ou se demorava muito tempo para encontrar uma forma perfeita para resolver o problema, ao invés de se adotar uma solução simples, mesmo que não fosse perfeita. Com o tempo a solução poderia ser aperfeiçoada. Portanto, é importante ressaltar a importância em sempre buscar soluções simples, práticas e rápidas pela equipe do EGP.

> Focar os principais problemas da organização: este fator está relacionado com a realização do diagnóstico atual (item 3.3.1), com o direcionamento estratégico (item 3.3.4), definição dos objetivos estratégicos (item 3.3.4) e a determinação das fases de implantação (item 3.3.4). Ou seja, é importante definir claramente quais são os principais problemas da organização que o EGP tratará e focar na solução destes. No caso específico da $\operatorname{LogB}$, como não foi realizado o planejamento estratégico no início das atividades do EGP, estes focos não foram definidos. Entretanto, os resultados obtidos mostraram a importância de tê-los definidos.

Foco em valor - gerar o maior valor possível no menor espaço de tempo: como comentado anteriormente, o EGP da LogB não definiu quais seriam as atividades no qual deveria focar para gerar valor rapidamente à empresa. $O$ fato de a LogB não ter realizado o planejamento estratégico no início da implantação e a estratégia de buscar atuar em todas as funções atribuídas ao EGP ao mesmo tempo, cooperou para que não fosse dispensado a atenção necessária nas atividades mais simples e que poderiam gerar valor à organização de maneira 
rápida. A conseqüência disto na $\operatorname{LogB}$ foi uma demora maior em obter o comprometimento e o respaldo dos principais stakeholders do EGP, aumentando assim o nível de resistência dos funcionários da empresa na implantação das práticas de gestão de projetos.

Estabelecer objetivos incrementais: como comentado anteriormente, os objetivos incrementais, ou seja, a determinação dos focos de atuação e a definição das fases de implantação não foram realizadas. Em função disto a equipe do EGP teve que atuar na solução de todos os problemas identificados e, portanto, a exercer todas as funções do EGP ao mesmo tempo. A conseqüência foi a perda de foco nas atividades iniciais, que deveriam ser as mais simples ou focando nos principais problemas. As atividades mais complexas e com maior risco deveriam ser deixadas para o médio e longo prazo.

> Procurar entender os problemas da organização de vários pontos de vista diferentes: essa preocupação sempre fez parte do dia a dia da equipe do EGP da LogB. Em todos os desenvolvimentos realizados houve a preocupação em se analisar os impactos em cada regional e nos mais diferentes departamentos. A equipe do EGP também tinha a preocupação de gerar soluções aplicáveis a todos os níveis organizacionais, ou seja, gerar solução que o nível operacional e o nível gerencial pudessem utilizar.

Reconhecer que a implantação de um EGP é muito mais do que desenvolver e implantar padrões e ferramentas - ao invés disso, é uma mudança cultural que mexe nos valores pessoais e da organização: este é um fator crítico fundamental, conforme já foi comentado anteriormente (item 3.3.8). Entretanto, o EGP da LogB acabou por priorizar o desenvolvimento de ferramentas ao invés de priorizar a busca por respaldo e comprometimento dos vários stakeholders. Este fato ficou evidente conforme a discussão no item da avaliação da maturidade (item 4.4.9.1) e no item da influência da cultura organizacional (item 4.4.8). A conseqüência disto foi uma demora maior em obter o respaldo e comprometimento das gerências executivas e de área, aumentando a resistência dos funcionários da empresa exatamente na utilização dos padrões e ferramentas desenvolvidos. 
> Formar a equipe do EGP com profissionais e gerentes de projetos seniores: a gerência do EGP decidiu impor como restrição a contratação de apenas profissionais certificados. Porém, a maioria dos profissionais certificados encontrados no mercado pode ser considerada júnior ou no máximo pleno. Pela restrição colocada, eles acabaram sendo contratados. Como era de se esperar, os profissionais mais juniores tiveram dificuldade em se posicionar perante profissionais mais seniores que não estavam dispostos a se comprometer com a aplicação da gestão de projetos. Os profissionais mais seniores, apesar de também sofrer a resistência, conseguiram se adequar melhor à situação. $A$ experiência mostrou, portanto, a importância de se constituir a equipe do EGP com profissionais seniores.

Integração com os sistemas de informação e os processos existentes na empresa: a equipe do EGP teve o cuidado de integrar a ferramenta e a metodologia de gestão de projetos aos sistemas e processos existentes na empresa. A ferramenta foi integrada à solução de ERP da empresa (SAP), de onde busca todos os custos realizados dos projetos. A metodologia levou em consideração no seu desenvolvimento os vários procedimentos e práticas já existentes na organização. Esta característica ajudou a minimizar as resistências das pessoas na utilização da ferramenta e da metodologia.

Comunicar os objetivos e sucessos atingidos pelo EGP: no início dos trabalhos do EGP não foi dada muita prioridade na comunicação de seus objetivos, o ocasionou um maior nível de resistência das suas atividades. Com o decorrer da implantação, novas ações objetivando a divulgação dos objetivos e das funções do EGP ajudaram a minimizar um pouco as resistências das pessoas. Entretanto, este fator crítico está muito relacionado com a busca do respaldo e comprometimento das pessoas da organização, ação que ainda necessita maior esforço.

Classificação dos projetos: Rad e Raghavan (2000) sugerem que os projetos devem ser tratados de forma diferenciada de acordo com seu tipo. Esta diferenciação foi aplicada na metodologia de gestão de projetos da empresa, estabelecendo ações específicas para projetos de pequeno, médio e grande 
porte financeiro. O ciclo de vida e as diretrizes são as mesmas para qualquer porte, porém a quantidade de informação solicitada é diferente para cada porte. A documentação de projetos de pequeno porte é mais simples, com informações básicas. Para projetos de grande porte a documentação é completa, com informações mais complexas. Esta diferenciação ajudou na implantação da metodologia, diminuindo focos de resistências.

E com base nos fatores críticos de fracasso identificados no item 3.3.10, os próximos parágrafos analisam como eles influenciaram a implantação do EGP na LogB.

> Esquecer os stakeholders chave do processo de implantação: conforme discutido anteriormente, deveria ter sido dado foco na busca de comprometimento e respaldo de todos os stakeholders chaves da implantação. Sem o comprometimento deles, o nível de resistência é muito alto.

Tentar mudar as pessoas, os processos e as ferramentas de uma única vez: o processo de implantação do EGP da LogB se baseou nas atividades ligadas às pessoas, processos e tecnologia, todas ocorrendo ao mesmo tempo. Conforme alerta do Crawford (2002) e das discussões apresentadas no item 3.3.4 (Objetivos estratégicos), é conveniente que estes três conjuntos de atividades não sejam realizados ao mesmo tempo. Com a definição das fases de implantação, estes itens deveriam ser distribuídos em ações de curto, médio e longo prazo. A realização dos três conjuntos de ações na LogB acarretou uma perda de foco, sendo que esforços da equipe poderiam ter sido concentrados apenas nas atividades principais e de curto prazo. Como lição aprendida, recomenda-se iniciar com o item pessoas, depois processos e por fim o item ferramentas.

Re-inventar a roda, ignorando idéias, conhecimento e experiências das demais pessoas da organização: a equipe do EGP teve o cuidado de não ignorar o conhecimento das outras pessoas da organização. Sempre que um novo desenvolvimento era necessário, a equipe do EGP buscava primeiramente como aquilo era feito na organização e como os próprios envolvidos recomendavam que fosse melhorado. Isto pode ser observado tanto no desenvolvimento da 
metodologia quanto da ferramenta. Essa atitude contribuiu para minimizar alguns focos de resistências.

Dar prioridade de implantação às ferramentas ao invés de concentrar esforços em obter altos níveis de integração entre departamentos: conforme já comentado, a equipe do EGP considerou que devido a alta qualidade da ferramenta desenvolvida internamente, esta deveria ser utilizada como um modo de ganhar o comprometimento das pessoas, consequentemente, facilitando a integração dos departamentos. Devido a isto, foi dada uma alta prioridade a implantação desta ferramenta. Entretanto, a opinião do autor coincide com a de Rad e Raghavan (2000), que recomenda dar prioridade a obtenção do comprometimento e respaldo dos stakeholders e na integração dos departamentos, para depois partir para a implantação de ferramentas. A realidade da implantação na $\operatorname{LogB}$ mostra que a ferramenta até pode ganhar alguns usuários em um primeiro momento, mas depois, durante sua utilização, este apoio não se mantém devido a dificuldade de utilização de um software sem que todas as áreas estejam comprometidas e alinhadas com a sua forma de trabalho.

Como conclusão, as análises apresentadas no item 3.3.10 se mostraram aplicáveis à situação real da LogB. Os fatores críticos de sucesso e de fracasso identificados neste item se mostraram coerentes e válidos quando aplicados no EGP da LogB.

\subsubsection{Os Recursos Humanos}

Neste item são apresentados os recursos humanos utilizados para formar a equipe do EGP da LogB. O EGP foi composto por 29 profissionais, considerando desde 0 nível operacional até os gerenciais, conforme Figura 30.

Os responsáveis pelas funções gerenciais (Gestão de Empreendimentos, Implantação e Manutenção, Apoio a Gestão, Acompanhamento e Controle) e das funções de coordenação (Coordenador da Regional) são ocupadas por funcionários 
próprios da empresa. As funções operacionais, mostradas na cor cinza na Figura 30, são ocupadas por funcionários terceirizados.

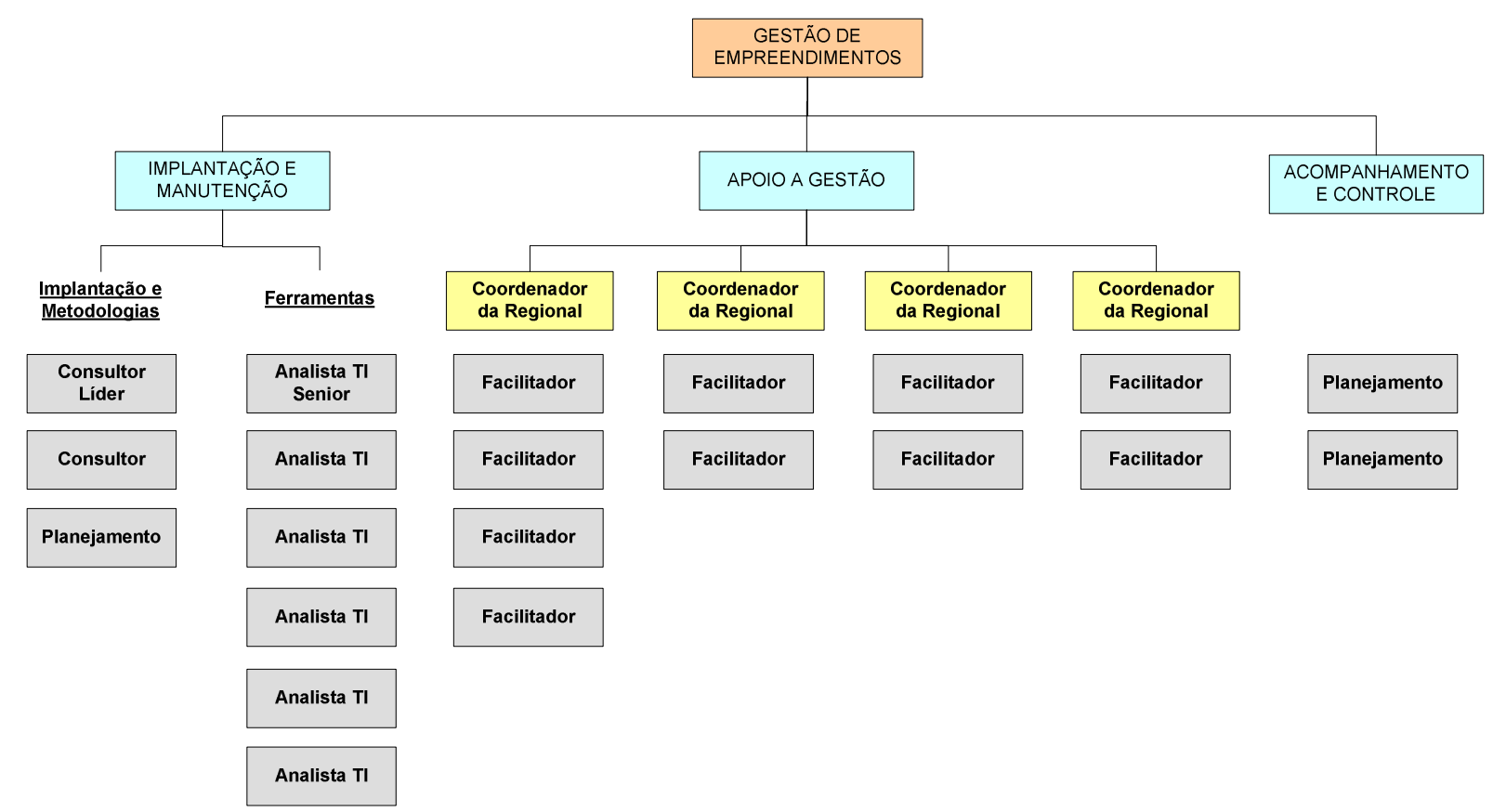

Figura 30: Organograma do EGP

(Fonte: autor)

As responsabilidades das três gerências estão descritas no item 4.4.6.2. As responsabilidades dos cargos operacionais são:

Consultor Líder: responsável pela empresa terceirizada contratada para administrar as ações de toda a equipe terceirizada.

$>$ Consultor: responsável pela elaboração da metodologia de gestão de projetos, incluindo seus padrões, procedimentos e check list. Fornece serviços de treinamento, especificação da ferramenta, consultoria, mentoring e planejamento estratégico do EGP.

> Planejamento (Implantação e Manutenção): responsável por controlar o planejamento das atividades da equipe do EGP.

> Analista TI Sênior: responsável líder pelo desenvolvimento da ferramenta de gestão de projetos.

$>$ Analista Tl; responsável pelo desenvolvimento da ferramenta de gestão de projetos. 
> Facilitador: responsável pela aplicação da metodologia e ferramenta junto aos usuários finais de projetos, em todas as áreas. Mantém contato com os usuários de projetos, buscando promover a mudança de cultura. Fornecem serviços de treinamento, consultoria e mentoring.

$>$ Planejamento (Acompanhamento e Controle): responsável pelo acompanhamento e controle de empreendimentos prioritários da organização.

A premissa para a contratação destes profissionais eram que deveriam ser todos seniores e com certificação. Devido à dificuldade em encontrar profissionais com este perfil no mercado, contrataram-se profissionais certificados, porém, nem todos considerados seniores.

\subsubsection{Custos da Implantação}

Neste item são apresentados os custos que foram necessários para a implantação do EGP na LogB. Os custos são:

$>$ Recursos Humanos (29 profissionais, entre próprios e terceirizados);

> Locação de espaço físico para o escritório;

> Mobiliário;

$>$ Computadores e servidores;

> Softwares: Windows, Office, MS Project, WBS Chart Pro e Visio;

$>$ Softwares para desenvolvimento da ferramenta e intranet;

> Biblioteca de gestão de projetos: vários livros;

> Elaboração de manuais, apostilas, material de apresentação e treinamento;

> Consultoria para elaboração do planejamento estratégico do EGP;

$>$ Viagens;

$>$ Gastos com a rotina administrativa.

Os seguintes custos estão embutidos nos custos de recursos humanos:

> Treinamentos da equipe do EGP;

$>$ Treinamentos para os diversos funcionários da organização; 
> Desenvolvimento da ferramenta de gestão de projetos;

$>$ Desenvolvimento da metodologia;

Dos custos do EGP, os relacionados aos recursos humanos correspondem a mais de $90 \%$ dos custos totais.

O EGP não possui fonte de renda própria. Sua renda é oriunda de uma parcela do overhead da organização.

Como conclusão, a itemização e composição dos custos da implantação apresentados no item 3.3.12 se mostraram aplicáveis à situação real da LogB.

\subsection{O PLANEJAMENTO DAS FASES}

Conforme apresentado no item 4.3, as etapas da implantação do EGP da LogB não seguiram as mesmas etapas propostas por este autor no item 3.2.2 e apresentada na Figura 5. As grandes etapas executadas durante a implantação deste EGP são melhores apresentadas na Figura 22.

Como comentado no item 4.3, o planejamento estratégico do EGP coincide com o planejamento estratégico descrito no item 3.3. E os planejamentos detalhados do ano 2007 e depois o do ano 2008, podem ser considerados como o planejamento das fases (tático / operacional), descrito no item 3.4.

Entretanto, vários dos assuntos que deveriam ser tratados nestes planejamentos detalhados de 2007 e 2008 acabaram sendo discutidos no que foi chamado de "planejamento informal", que ocorreu durante o ano de 2006, de acordo com a Figura 22.

Portanto, as análises realizadas nos próximos itens levam em consideração tanto as decisões tomadas nos planejamento detalhados dos anos de 2007 e 2008 quanto no planejamento informal. Os itens seguintes analisam os aspectos da elaboração do planejamento das fases, conforme apresentado no item 3.4. 


\subsubsection{O Plano de Projeto}

Para a elaboração do plano do projeto, a empresa trabalhou segundo as melhores práticas divulgadas pelo Project Management Institute.

Conforme apresentado no item 3.4 e segundo o PMI (2004), o planejamento da fase deveria ter iniciado com a elaboração e emissão do Termo de Abertura do Projeto. Este documento deveria documentar os aspectos do planejamento estratégico que deveriam ser aplicados na respectiva fase. No caso do EGP da LogB, este documento não foi emitido. Este fato é compreensível, pois o EGP nasceu não para ser um EGP, mas para ser um departamento da empresa, o que não caracterizaria a necessidade de emissão de um Termo de Abertura.

Em seguida, segundo o item 3.4, deveriam ser analisadas todas as áreas de conhecimento do PMBoK para a emissão do Plano do Projeto. No EGP da LogB, o Plano do projeto consistiu no desenvolvimento dos seguintes itens:

> Declaração de escopo com desenvolvimento da EAP;

> Cronograma de implantação com desenvolvimento da curva S;

Matriz de responsabilidades;

$>$ Recursos necessários;

> Treinamentos necessários;

> Matriz dos stakeholders;

> Plano de comunicação;

> Identificação e plano de resposta dos principais riscos.

A declaração de escopo indicou as funções designadas ao EGP da LogB, as premissas e restrições envolvidas e elaborou a estrutura analítica do projeto (EAP). A EAP desenvolvida para o projeto é apresentada na Figura $31^{13}$.

\footnotetext{
${ }^{13}$ A EAP apresentada retrata as funções definidas durante a etapa do Planejamento Informal. Portanto, não retrata algumas funções que foram designadas durante o Planejamento Estratégico do EGP (Figura 22).
} 
A EAP foi dividida em três seções, conforme os agrupamentos descritos nos capítulos anteriores: pessoas, processos e tecnologia.

No grupo pessoas estavam os entregáveis ligados ao desenvolvimento das pessoas (treinamentos) e ao processo de mudança cultural, que envolvia influenciar e convencer as pessoas a aceitar e aplicar a gestão de projetos.

No grupo processos estavam os entregáveis ligados à elaboração da metodologia de gestão de projetos e os procedimentos associados à metodologia. Incluía também os entregáveis referentes à avaliação da maturidade em gestão de projetos da organização e para realizar um diagnóstico da forma como a empresa geria seus empreendimentos. Estava incluso também os entregáveis necessários para a implantação dos processos desenvolvidos.

No grupo tecnologia estavam os entregáveis ligados ao desenvolvimento da ferramenta de gestão de projetos customizada às necessidades da empresa. Incluía o lançamento da primeira versão e uma previsão para as futuras versões. Estava também incluso o desenvolvimento do portal do departamento a ser implantado na intranet da empresa.

Foi desenvolvido um cronograma de implantação com cada um dos entregáveis da EAP, indicando o responsável por cada atividade (matriz de responsabilidades). Foi desenvolvida também a curva $\mathrm{S}$ do projeto.

Todos os recursos necessários foram definidos, incluindo os recursos humanos, materiais, equipamentos, serviços e consultorias.

Para os profissionais que estariam entrando na empresa neste projeto, foi previsto que eles seriam treinados, com o objetivo de conhecer a forma de trabalho da empresa, suas particularidades e rotinas operacionais. Esta atividade foi muito importante, pois facilitou muito o processo de adaptação dos facilitadores nas áreas operacionais e o contato com seus clientes. 

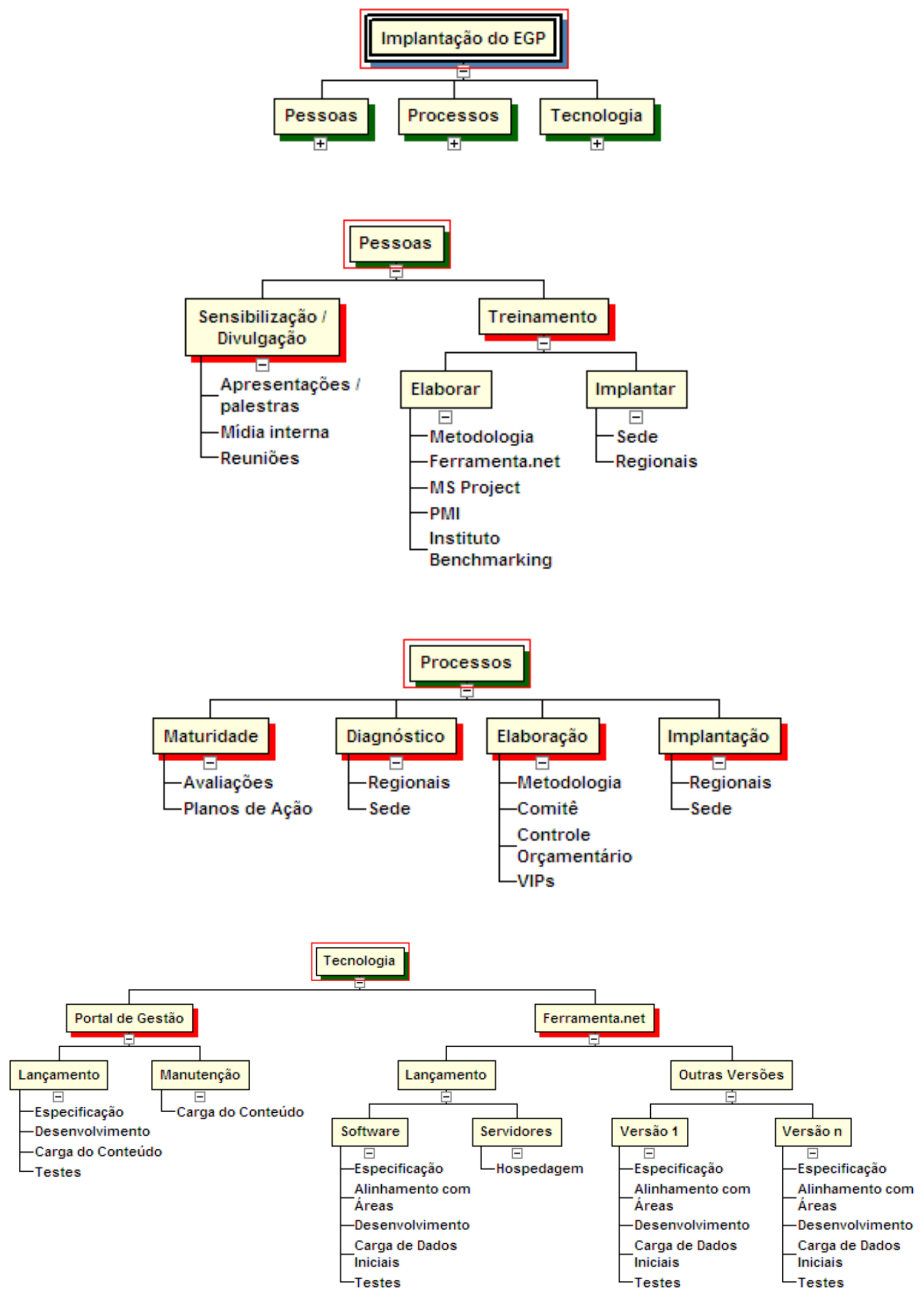

Figura 31: EAP do projeto

(Fonte: autor) 
Foi realizada a análise dos stakeholders envolvidos na implantação do EGP. Foram identificadas 19 áreas envolvidas (não se detalhou no nível das pessoas). Para estas foi montado um plano de ação. Foi elaborada também a matriz de comunicação do projeto, o qual identificou 31 tipos de comunicações diferentes a serem realizadas. A elaboração da análise dos stakeholders foi uma atividade importante para o planejamento e a implantação do EGP, pois possibilitou uma visualização geral de todas as áreas que deveriam ser atendidas pelo EGP.

O plano também incluiu a identificação dos riscos do projeto e seu plano de ação. Os riscos identificados foram:

Gerenciamento:

* Perda do patrocínio da alta administração;

* Resistência das pessoas às mudanças;

* Comunicação ineficiente entre a equipe do empreendimento;

* Mudanças constantes no escopo do empreendimento;

* Ineficiência no controle do escopo;

* Demora na tomada de decisões e aprovações;

* Atrasos nas atividades do empreendimento;

* Estouro do orçamento;

* Recursos humanos super-dimensionados;

* Dificuldades de integração com as Regionais;

* Dificuldades de integração com Gerências Funcionais.

Pessoas:

* Demanda de capacitação superior ao previsto;

* Perfis de palestras inadequados aos públicos alvo;

* Falta de manutenção periódica das informações no Portal do EGP.

$>$ Processos:

* Aplicação inadequada ou atrasada da avaliação de maturidade;

* Elaboração de padrões e modelos inadequados às áreas;

* Seleção de projetos pilotos inadequados.

$>$ Tecnologia:

* Mudança constante de escopo;

* Dados inconsistentes na ferramenta; 
* Erros nas interfaces com outros softwares;

* Falta de manutenção periódica das informações da ferramenta;

Destes riscos previstos, os que se tornaram reais foram: resistência das pessoas às mudanças; demora na tomada de decisões e aprovações; atrasos nas atividades do departamento; dificuldade de integração com as Gerências Funcionais; mudança constante de escopo da ferramenta de gestão de projetos; e falta de manutenção periódica das informações da ferramenta.

A forma de controle da execução do plano do projeto estabelecida foi através do cronograma e da curva $S$ elaborados.

A elaboração do plano do projeto foi uma atividade importante para a implantação do EGP da LogB, pois sua primeira emissão ocorreu durante a etapa denominada "Planejamento Informal" (Figura 22). O plano conseguiu determinar um mínimo de informações necessárias para a realização da implantação.

Como conclusão, pode-se dizer que as análises apresentadas no item 3.4 se mostraram aplicáveis à situação real da LogB. Quanto a emissão do Termo de Abertura, apesar de não ter sido emitido pela LogB, este ainda é um documento importante para a abertura de uma das fases. O plano do projeto se mostrou coerente e importante para detalhar as ações da fase.

\subsection{A IMPLANTAÇÃO DO EGP}

Conforme apresentado no item 4.3, Figura 22, a implantação das atividades do EGP ocorreu de forma paralela ao chamado "Planejamento Informal". Assim que foi oficializada a criação do departamento, foram nomeados seus gerentes $\mathrm{e}$ estabelecido um contrato com uma empresa terceirizada para fornecimento de profissionais de planejamento, gestão de projetos e analistas de sistemas, que iriam atuar no EGP, tanto na sede quanto nas regionais. A empresa terceirizada foi autorizada a contratar e alocar os profissionais previstos no contrato já no início de 2006. 
Dessa forma se iniciaram as atividades do EGP, com a equipe trabalhando tanto na elaboração do plano do projeto quanto nas atividades designadas ao EGP na sede e nas regionais.

Os profissionais que estavam entrando no projeto naquele momento passaram inicialmente por um treinamento, objetivando a familiarização com as macros rotinas da empresa e apresentação de suas atividades dentro do EGP.

A partir disso, estes profissionais passaram a trabalhar conforme as diretrizes contidas no plano do projeto.

É interessante notar o comentário apresentado por Kerzner (2002) e Mintzberg, Ahlstrand e Lampel (2000) de que as estratégias e ações previstas no planejamento estratégico podem alterar durante a implantação. No caso do EGP da LogB, algumas decisões tomadas durante seu planejamento estratégico tiveram que ser revistas, sendo que algumas estratégias não puderam ser implantadas e outras novas estratégias surgiram.

A implantação do EGP ainda continua e no próximo item são apresentados alguns resultados já obtidos.

\subsection{OS RESULTADOS OBTIDOS}

De acordo com o item 3.3.2, os benefícios esperados com a implantação do EGP da LogB devem estar compatíveis com os problemas de gestão de projetos que lhe foram designados para solução. Nos próximos parágrafos são apresentados os resultados obtidos por este EGP após dois anos do início de sua implantação, ou seja, dois anos após a criação do departamento de Gestão de Empreendimentos (Figura 22).

O trabalho realizado pela equipe do EGP trouxe significativa melhora na popularização dos conceitos de gestão de projetos e nos benefícios de sua 
utilização entre todos os níveis organizacionais da empresa. Aumentou o número e a qualidade das discussões sobre práticas de gestão de projetos e gerou uma linguagem comum entre as pessoas envolvidas com projetos. Ocorreu também uma significativa melhora na conscientização das pessoas da empresa da necessidade de se investir em gestão de projetos, com o intuito de melhorar o desempenho dos projetos realizados na empresa.

O desenvolvimento da metodologia de gestão de projetos trouxe significativos benefícios. Um deles foi estabelecer uma forma de trabalho com a gestão de projetos única para toda organização. Outro foi indicar a meta onde todos devem chegar, deixando mais claro quais as ações são necessárias para se alcançar a maturidade. Um terceiro benefício foi estabelecer uma rotina de gestão de projetos que pudesse ser auditável, ou seja, que facilitasse a realização de auditorias nos projetos para acompanhar se estão ou não aplicando a gestão de projetos. 0 número de projetos onde se está aplicando a metodologia por completa ainda é pequeno, perto do número de projetos do portfólio da empresa, mas este número está crescendo regularmente.

Muitos treinamentos foram oferecidos aos funcionários da empresa, tanto próprios como terceirizados. Foram dados treinamentos de gestão de projetos, técnicas de planejamento, EAP, cronograma, metodologia e ferramenta de gestão de projetos da LogB, elaboração de plano de projetos e MS Project. Estes treinamentos ajudaram a criar uma massa crítica com conhecimento em gestão de projetos e que estão ajudando a divulgar e a retransmitir estas práticas aos restantes dos funcionários da empresa.

A ferramenta de gestão de projetos foi desenvolvida e implantada. As funcionalidades básicas estão liberadas para utilização, as quais focam custo, cronograma, relatórios de progresso e repositório de documentos. O número de projetos que estão utilizando a ferramenta para apoio ao gestor de empreendimentos ainda é pequeno face o número de projetos de seu portfólio, mas este número também vem crescendo regularmente. 
Um reflexo deste processo de mudança de cultura organizacional vem sendo observado pela maior valorização das atividades de planejamento do empreendimento. Este processo ainda não está consolidado faltando muito ainda a ser feito, mas é possível notar melhorais neste assunto e várias atitudes espalhadas pela empresa que mostram esta valorização.

Um exemplo desta valorização é a ação realizada por um departamento da empresa em iniciar as ações para desenvolver a gestão de portfólio da organização. Esta área já iniciou os trabalhos de desenvolvimento dos procedimentos que darão base à gestão de portfólios.

Um outro resultado positivo encontrado é o aumento do número de indicações de Gestores de Empreendimentos (gerentes de projetos) para os projetos da organização. Antes do trabalho do EGP não existia o conceito de se ter um responsável único pelo projeto, do seu início até o fim. Agora já existem vários projetos com Gestores indicados, com a equipe do projeto formada, e estes se responsabilizando pelo empreendimento do início ao fim. Em termos proporcionais ao portfólio da empresa, o número de projetos com Gestores ainda é pequeno, mas esta cultura está relativamente bem aceita e vem mostrando um bom crescimento regular.

Um ponto que ainda necessita maior desenvolvimento é a integração das áreas. Houve uma melhora neste item, mas ainda necessita haver uma maior integração. Relacionado a este assunto, também há necessidade de melhorar o comprometimento e o respaldo das áreas com as ações do EGP e com a aplicação das práticas de gestão de projetos. Conforme comentado anteriormente, melhores resultados das ações do EGP dependem fundamentalmente de se aumentar o apoio visível da alta e média administração na aplicação das práticas de gestão de projetos.

Os reflexos das ações do EGP ainda não puderam ser verificados nos projetos em si, porque em sua maioria, os projetos da organização são de longa duração, e, portanto, ainda não foram concluídos. 
É possível verificar que vários resultados positivos foram alcançados. Mas fica evidente também que ainda há muito por se fazer e muito por se alcançar. Como esta implantação coincide com um processo de mudança cultural, seus resultados são perceptíveis no longo prazo. Os resultados positivos alcançados até o momento indicam que a direção está correta e que devem ser mantidos os esforços na busca da excelência em gestão de projetos da organização.

\subsection{CONCLUSÕES E RECOMENDAÇÕES DO ESTUDO DE CASO}

No decorrer do estudo de caso foi possível verificar que todas as recomendações e idéias apresentadas no capítulo 3 foram coerentes com a aplicação no EGP da LogB e mostraram que se fossem implantadas, poderiam ser obtidos melhores resultados com a implantação do EGP.

Portanto, conclui-se que seria viável a aplicação do conteúdo do capítulo 3 para se planejar a implantação do EGP da LogB.

Os pontos onde foram detectadas maiores divergências entre o estudo de caso e os fundamentos teóricos são apresentados nos próximos parágrafos. Eles indicam que se tivessem sido aplicados no EGP da LogB, melhores resultados poderiam ter sido obtidos na sua implantação.

O ponto mais importante é que o planejamento estratégico do EGP deveria ter sido realizado no início de todo o processo, ou seja, no início de 2006 (conforme Figura 22), antes do início das atividades de implantação do EGP.

Consequentemente, todos os assuntos relacionados ao planejamento estratégico do EGP deveriam ter sido esclarecidos e documentados antes do início da implantação. Um dos principais é a definição dos objetivos estratégicos do EGP e a definição das fases de implantação. Estas fases também definiriam os focos de atuação do EGP e deixariam claros os problemas que estavam sendo tratados por fase e quais benefícios podiam ser esperados em cada uma das fases. 
Outro ponto importante é que a contratação dos funcionários terceirizados deveria ter ocorrido após a conclusão do planejamento estratégico acima referido.

Ficou claro também na avaliação da maturidade em gestão de projetos da LogB, a necessidade de focar a busca pelo respaldo e comprometimento dos vários stakeholders envolvidos, desde a alta administração até o nível operacional. Somente com o forte desenvolvimento deste assunto é que se poderá obter maiores e melhores resultados com a implantação do EGP.

Como conclusão é relevante ressaltar a importância do papel do EGP dentro desta organização, que tem uma missão de extrema importância para a expansão da empresa e está realizando um trabalho com êxitos dentro do pouco tempo que teve, considerando que se trata de processo de mudança cultural. Tendo uma visão de mais longo prazo, é possível observar que a empresa está seguindo na direção correta e que no futuro irá colher os benefícios deste investimento. 


\section{CONCLUSÕES E RECOMENDAÇÕES}

Uma pesquisa realizada por Hobbs e Aubry (2007), comentada no item 1.1, mostra que um número expressivo de EGP tem sido fechado ou reestruturado nos últimos anos. Um pressuposto adotado nesta dissertação é que um planejamento da criação do EGP bem realizado poderia evitar estes problemas.

O objetivo desta dissertação foi analisar quais são os fatores e como eles influenciam o processo de planejamento da implantação de um EGP de tal forma que propicie uma implantação de sucesso.

Deste modo, a dissertação atinge seu objetivo com a apresentação de análises que abrangem os seguintes fatores do processo de planejamento de um EGP: a conceituação de EGP, o processo de constituição de um EGP, o processo de planejamento estratégico do EGP e o processo de planejamento das fases de um EGP. Dentro do processo de planejamento estratégico do EGP, foram também analisados os seguintes fatores: diagnóstico da situação atual, benefícios esperados, condições de viabilidade para implantação, objetivos estratégicos, tipos de EGP, funções, a influência da estrutura organizacional, a influência da cultura organizacional, a influência da maturidade em gestão de projetos, a influência dos fatores críticos de sucesso e os recursos e custos envolvidos.

Todas as análises apresentadas no capítulo de fundamentos teóricos puderam também ser verificadas sua aplicação, viabilidade e coerência em um estudo de caso.

Da análise comparativa entre os fundamentos teóricos e o estudo de caso, podemse retirar as seguintes conclusões:

Todas as análises, conceitos e idéias apresentadas no capítulo dos fundamentos teóricos se mostraram aplicáveis ao estudo de caso. Todas as situações analisadas indicaram que se as questões tratadas nos fundamentos teóricos fossem 
implementadas em casos reais, as chances de sucesso da implantação do EGP seriam significativamente maiores.

Os resultados apresentados pelo estudo de caso indicam que os pontos negativos da implantação do EGP da LogB são reflexos da não aplicação dos conceitos e recomendações apresentados no capítulo dos fundamentos teóricos. Um exemplo foi a não realização do planejamento estratégico do EGP logo no início da implantação.

As várias propostas apresentadas pelo autor no decorrer do capítulo de fundamentos teóricos também se mostraram coerentes quando aplicadas no estudo de caso.

A proposta do autor para definição das etapas de implantação de um EGP conforme apresentado no item 3.2.2, Figura 5, se mostrou viável e coerente, se mostrando um método fácil, simples, direto e eficaz para planejar as etapas de implantação de um EGP.

O estudo de caso também mostrou a relevância da discussão de cada um dos assuntos incluídos no item de definição dos Objetivos Estratégicos (item 3.3.4). Principalmente a definição das fases de implantação do EGP.

O agrupamento de funções do EGP proposto pelo autor (Tabela 8) também se mostrou coerente e de fácil aplicação para apoiar na definição de quais funções poderiam ser designadas ao EGP.

As análises referentes ao posicionamento do EGP na estrutura organizacional (item 3.3.7.5) também se mostraram coerentes quando aplicadas no estudo de caso. Os três fatores que podem influir neste posicionamento se mostraram coerentes, sendo eles: necessidade de ter um ou mais EGP; definição se os gerentes de projetos ficarão ou não dentro do EGP; e a associação entre as funções com o nível de autoridade designado ao EGP. Para esta última, vale ressaltar a importância das análises, que indicaram a divisão das influências por grupos de funções. 
Também se mostrou coerente a conclusão de que para se planejar a implantação de um EGP, o importante não é definir seu tipo, mas sim definir as funções que o EGP terá e qual será sua autoridade para desempenhar estas funções. A composição destas duas características indicará o tipo de EGP (Verzuh, 2005).

As influências da cultura organizacional e da maturidade em gestão de projetos se mostraram fundamentais para o planejamento do EGP. Por se tratar de um processo de mudança de cultura organizacional, entender como se tratam as pessoas e as resistências que elas provocam é fundamental para evitar um fracasso da implantação. A avaliação da maturidade é importante para esclarecer qual a situação atual e qual o caminho deve ser tomado em busca da maturidade.

O estudo de caso também mostrou coerente a influência dos fatores críticos de sucesso e de fracasso. Nos pontos onde eles não foram levados em consideração, problemas ocorreram na implantação. Entretanto, não foi possível identificar quais fatores críticos seriam mais ou menos importantes. Todos se mostraram importantes.

Um ponto que ficou evidente tanto nos fundamentos teóricos quanto no estudo de caso foi a constatação que um EGP deve ser customizado à empresa onde está sendo implantado (Desouza e Evaristo, 2006).

E das análises e conclusões realizadas, a mensagem mais importante a ser lembrada na implantação de um EGP, é que esta implantação se trata de uma transformação organizacional, e ela só se efetiva com as pessoas, para as pessoas e através do envolvimento e do comprometimento das pessoas (Fischer, 2002). Caso este recomendação não seja obedecida, as chances de sucesso da implantação do EGP serão mínimas.

Como conclusão final, não existe uma "receita de bolo" para a implantação de um EGP. Os responsáveis pela implantação devem entender quais fatores afetam o planejamento do EGP, como eles afetam e trabalhar no intuito de melhor adaptar estes fatores na sua empresa. 
Como recomendação para futuros estudos, recomenda-se o aprofundamento do estudo dos seguintes assuntos: influência da cultura organizacional na implantação de um EGP, focando principalmente os aspectos ligados ao comportamento humano perante um processo de mudança de cultura organizacional; análise mais detalhada do processo de execução do planejamento realizado, focando os principais problemas que costumam ocorrer na fase de implantação, sendo desejável a análise através de um estudo de caso da implantação real de um EGP; e também a análise das diferenças da implantação de um EGP numa empresa privada e numa empresa pública.

Dessa maneira, esta dissertação atinge seu objetivo, apresentando uma visão de quais são estes fatores, como eles afetam o planejamento e quais os possíveis caminhos que podem ser tomados para se poder implantar com sucesso um EGP. 


\section{REFERÊNCIAS BIBLIOGRÁFICAS}

ACKOFF, R. L. Redesigning the future: a systems approach to societal problems. New York: John Wiley, 1974. [apud Oliveira (2002)].

ANDERSEN, B.; HENRIKSEN, B. \& AARSETH, W. Project Management Office Establishment Best Practices. Annual Publication of International Project Management Association, 2006.

BLOCK, T.R.; FRAME, D. The Project Office. Menlo Park, California: Crisp Management Library, 1998.

BONOMA, T. V. Case research in marketing: opportunities, problems and process. Journal of Marketing Research, 1985. [apud Harrison (2006)].

CASEY, W.; PECK, W. Choosing the Right PMO Setup. PM Network, 2001.

COSTA, E. A. Gestão Estratégica. São Paulo: Saraiva, 2006.

CRAWFORD, J.K. The Strategic Project Office - A Guide to Improving Organizational Performance. New York: Taylor \& Francis Group, 2002.

DAI, C. X. Y.; KWAK, Y. H. Assessing the value of project management offices. PMI Research Conference, 2000.

DAI, C. X.; WELLS, W.G. An exploration of project management office features and their relationship to project performance. International Journal of Project Management, 22, 2004.

DESOUZA, K.C.; EVARISTO, J.R. Project management offices: A case of knowledge-based archetypes. International Journal of Information Management, 2006.

DINSMORE, P. C. Winning Business with Enterprise Project Management. New York: AMACOM, 1998. 
DINSMORE, P.C. Implementing Project Office Cultural Change. PM Network, 2001.

DINSMORE, P.C. Sixteen Reasons Not to Implement a Project Office. PM Network, 2002.

ENGLUND, R.L.; GRAHAM, R.J.; DINSMORE, P.C. Creating the project office: a manager's guide to leading organizational change. John Wiley \& Sons, 2003.

FISCHER, R.M. Mudança e Transformação Organizacional. Artigo incluso no livro: FRANÇA, A.C.L. et al. As Pessoas na Organização. Editora Gente, 2002.

FLEURY, M.T.L.; SAMPAIO, J.R. Uma Discussão sobre Cultura Organizacional. Artigo incluso no livro: FRANÇA, A.C.L. et al. As Pessoas na Organização. Editora Gente, 2002.

GIL, A. C. Como Elaborar Projetos de Pesquisa. São Paulo: Editora Atlas, 2007.

GONZÁLEZ, F.; RODRIGUES, I. Implementação de Escritórios de Gerenciamento de Projetos, Monografia (MBA em Projetos) - FEA/USP. São Paulo, 2002.

GOODE, W. J.; HATT, P.K. Métodos em pesquisa social. São Paulo: Cia Editora Nacional, 1969. [apud Harrison (2006)]

HARRISON, P.D. Análise e resultados da aplicação de modelos de maturidade em gerenciamento de projetos em uma organização: um estudo de caso. Dissertação de Mestrado. São Paulo, USP, 2006.

HOBBS, B.; AUBRY, M. A Multi-Phase Research Program Investigating Project Management Offices (PMOs): The Results of Phase 1. Project Management Journal, Volume 38, Number 1, 2007.

KAPLAN, R. S.; NORTON, D. P. Organização orientada para a estratégia: como as empresas que adotam o Balanced Scorecard prosperam no novo ambiente de negócios. Rio de Janeiro: Campus, 2001. [apud Oliveira (2007)]

KATE, J. Program Office: An Enterprise View. 2000. 
KERZNER, H. Project Management - A System Approach for Planning, Scheduling and Controlling. New York: John Wiley \& Sons, 2001a.

KERZNER, H. Strategic Planning for Project Management using a Project Management Maturity Model. New York: John Wiley \& Sons, 2001b

KERZNER, H. Gestão de projetos: As melhores práticas. Bookman, 2002.

KERZNER, H. Strategic Planning for a project office. Project Management Journal, 2003.

LAKATOS, E. M.; MARCONI, M. A. Fundamentos de Metodologia Científica. São Paulo: Atlas, 2003.

LITKE, H.D. Projekt-management: Methoden, Techniken, Verhaltensweisen. München e Wien: Carl Hansen: 1995. [apud Patah (2004)].

MEREDITH, J.R; MANTEL Jr, S.J. Project Management a Managerial Approach. New York: John Wiley \& Sons, Inc, 2000.

MINTZBERG, H.; AHLSTRAND, B.; LAMPEL, J. Safári de Estratégia: um Roteiro pela Selva do Planejamento Estratégico. Porto Alegre: Bookman, 2000.

OLIVEIRA, A. F. Gestão de Projetos Estratégicos: um Estudo de Caso. Dissertação de Mestrado. São Paulo: USP; 2007.

OLIVEIRA, D. P. R. Planejamento Estratégico: conceitos, metodologia e práticas. São Paulo: Atlas, 2002.

OLIVEIRA, M. S. Orientações Metodológicas para Monografias de Lato Sensu. Universidade Federal de Lavras, 2005.

PATAH, L. A. Alinhamento Estratégico de Estrutura Organizacional de Projetos: Uma Análise de Múltiplos Casos. Dissertação de Mestrado. São Paulo: USP; 2004. 
PATAH, L. A.; CARVALHO, M.M. O Processo de Implementação de um Project Management Office. In: Seminário Gestão de Projetos 2003, SUCESU-SP. São Paulo, 2003. [apud Patah (2004)].

PATAH, L. A.; CARVALHO, M. M.; LAURINDO, F. J. B. O PMO como Tradutor das Estratégias Corporativas: Um Estudo de Caso no Setor de Telecomunicações. In: X Simpósio de Engenharia de Produção, SIMPEP 2003. Bauru: 2003.

PHILLIBER, S. G.; SCHWAB, M. R.; SAMSLOSS, G. Social research: guides to a decision-making process. Itaska: Peacock, 1980. [apud Harrison (2006)].

PMI, PROJECT MANAGEMENT INSTITUTE. Organizational Project Management Maturity Model (OPM3). Project Management Institute Inc., 2003.

PMI, PROJECT MANAGEMENT INSTITUTE. A Guide to the Project Management Body of Knowledge (PMBoK). Project Management Institute Inc., 2004.

RAD, P. F.; RAGHAVAN. A. Establishing an organizational project office, AACE International Transactions, 2000.

RAD, P.F., Is Your Organization a Candidate for Project Management Office (PMO) ?, AACE International Transactions, 2001.

RABECHINI, R.; CARVALHO, M.M.; LAURINDO, J.B. Fatores críticos para implementação de gerenciamento por projetos: o caso de uma organização de pesquisa. Revista Produção, 2002.

RUDIO, F. V. Introdução ao projeto de pesquisa científica. Petrópolis: Vozes, 1979. [apud Lakatos (2003)].

SALVADOR, A. D. Métodos e técnicas de pesquisa bibliográfica: elaboração de trabalhos científicos. Porto Alegre: Sulima, 1980 [apud Lakatos (2003)].

SBRAGIA, R.; RODRIGUES, I.; GONZÁLES, F. Escritório de Gerenciamento de Projetos: Teoria e Prática. Working Papers - FEA. USP, 2002.

SCHEIN, E. H. Guia de sobrevivência da cultura corporativa. Rio de Janeiro: José Olympio, 2001. [apud Fleury e Sampaio (2002)]. 
SNYDER, J.R. Pros and Cons of the Project Management Office, PM Knowledge Wire, 2002.

STAKE, R. E. Case Studies. In: Denzin, N.; Lincoln, Y. (Ed.). Handbook of qualitative research. Thousand Oaks: Sage, 2000 [apud Gil (2007)].

STEINER, G. A. Top Management Planning. New York: Macmillan, 1969. [apud Oliveira (2002)].

TOLEDO, N. N.; ROVAI, R. 0 alinhamento dos projetos às estratégias organizacionais. São Paulo: II Seminário Internacional do PMI-SP, 2002.

TRIPODI, T. et al. Análise da Pesquisa Social: Diretrizes para o uso de Pesquisa em Serviço Social e em Ciências Sociais. Rio de Janeiro: Francisco Alves, 1975. [apud Lakatos (2003)].

TRUJILLO, F. A. Metodologia da Pesquisa Científica. São Paulo: McGraw-Hill, 1982.

TULL, D. S.; HAWKINS, D. I. Marketing research, meaning, measurement and method. London: Macmillan Pub., 1976. [apud Harrison (2006)].

VERZUH, E. The Fast Forward MBA in Project Management. New York: John Wiley \& Sons, 2005.

WARD, L. Project Management Term - a Working Glossary. ESI International, 2000. [apud Dai e Well (2004)]

YIN, R.K. Estudo de Caso - Planejamento e Métodos. Bookman, 2005. 


\section{ANEXOS}

\subsection{Anexo 1 - Questionário do PMMM}

Este anexo apresenta as perguntas do questionário do modelo PMMM, retiradas do livro do Kerzner (2002). São apresentadas somente o questionário referente ao nível 2 de maturidade, por ter sido apenas este utilizado nesta dissertação.

\section{Fase Embrionária:}

$>$ № 1 - Minha empresa reconhece a necessidade da gestão de projetos. Esta necessidade é reconhecida em todos os níveis da gerência, inclusive pela gerência sênior.

$>$ no 3 - Minha empresa tem reconhecido as vantagens possíveis de serem alcançadas através da implementação da gestão de projetos. Estes benefícios são reconhecidos em todos os níveis gerenciais, incluindo a gerência sênior.

$>$ no 14 - Nossos executivos reconheceram ou identificaram as aplicações da gestão de projetos nas várias divisões do nosso empreendimento.

$>$ no 17 - Nossos executivos reconheceram o que precisa ser feito a fim de ser alcançada a maturidade em gestão de projetos.

\section{Fase de Aceitação pela Gerência Executiva:}

$>$ ํ 5 - Nossos executivos apóiam ostensivamente a gestão de projetos, por meio de palestras, correspondência e inclusive pela presença ocasional em reuniões e relatórios da equipe de projetos.

$>$ ํo 10 - Os executivos em minha empresa têm bom conhecimento dos princípios da gestão de projetos.

$>$ no 13 - Nossos executivos compreendem o conceito de responsabilidade e atuam como responsáveis em determinados projetos.

$>$ no 20 - Nossos executivos têm demonstrado disposição para mudanças na maneira tradicional de conduzir negócios para chegar à maturidade em gestão de projetos. 


\section{Fase de Aceitação pelos Gerentes de Área:}

> no 7 - Nossos gerentes de áreas de níveis médio e inicial apóiam por inteiro e ostensivamente o processo de gestão de projetos.

$>$ no 9 - Nossos gerentes de áreas estão comprometidos não apenas com a gestão dos projetos, mas também com o cumprimento dos prazos estabelecidos para a conclusão dos objetivos.

$>$ o 12 - Nossos gerentes de áreas de níveis médio e inicial foram treinados e instruídos em gestão de projetos.

$>$ no 19 - Nossos gerentes de escalão médio e inicial estão dispostos a liberar seus funcionários para treinamento em gestão de projetos.

\section{Fase de Crescimento:}

$>$ no 4 - Minha empresa (ou departamento) tem uma metodologia facilmente identificável de gestão de projetos que utiliza as fases do ciclo de vida.

> no 6 - Minha empresa tem compromisso com o planejamento antecipado visando a qualidade. Tentamos fazer sempre o melhor possível em matéria de planejamento.

> № 8 - Minha empresa faz o possível para minimizar os "desvios" de escopo (mudanças de escopo) em nossos projetos.

$>$ no 11 - Minha empresa selecionou um ou mais softwares para serem utilizados como sistema de controle de projetos.

\section{Fase de Maturidade:}

$>$ no 2 - Minha empresa tem um sistema para gerenciar tanto o custo quanto o cronograma. O sistema requer números de encargos financeiros e códigos de conta contábil. O sistema informa variações em relação aos objetivos planejados.

$>$ no 15 - Minha empresa conseguiu integrar com sucesso o controle de custo e cronogramas tanto para a gestão de projetos quanto para relatórios de situação. 
$>$ no 16 - Minha empresa desenvolveu um currículo de gestão de projetos (ex.: mais do que um ou dois cursos) para o aperfeiçoamento das qualificações de nossos funcionários em gestão de projetos.

> no 18 - Minha empresa considera e trata a gestão de projetos como profissão e não apenas como tarefa de tempo parcial. 